\title{
EMERGENCY MEDICALSERVICE
}

RATOWNICTWO MEDYCZNE

PROGNOSTIC FACTORS OF CHRONIC CORONARY SYNDROME IN PATIENTS WITH CONCOMITANT TYPE 2 DIABETES MELLITUS

DIFFERENCES BETWEEN ETCO ${ }_{2}$ IN A PATIENT WITH PULMONARY EMBOLI

TRIAGE AND EMERGENCY MEDICAL MANAGEMENT OF THE ACUTE RADIATION SYNDROME

THE USE OF SURVIVAL TECHNIQUES IN RESCUE PROCEEDINGS

Vol. 7 | No 3 | 2020

July - September

ISSN 2391-7822

Czasopismo jest beneficjentem programu Ministra Nauki i Szkolnictwa Wyższego "Wsparcie dla czasopism naukowych" 
EMERGENCY MEDICALSERVICE RATOWNICTWO MEDYCZNE 


\section{PATRONAGES}
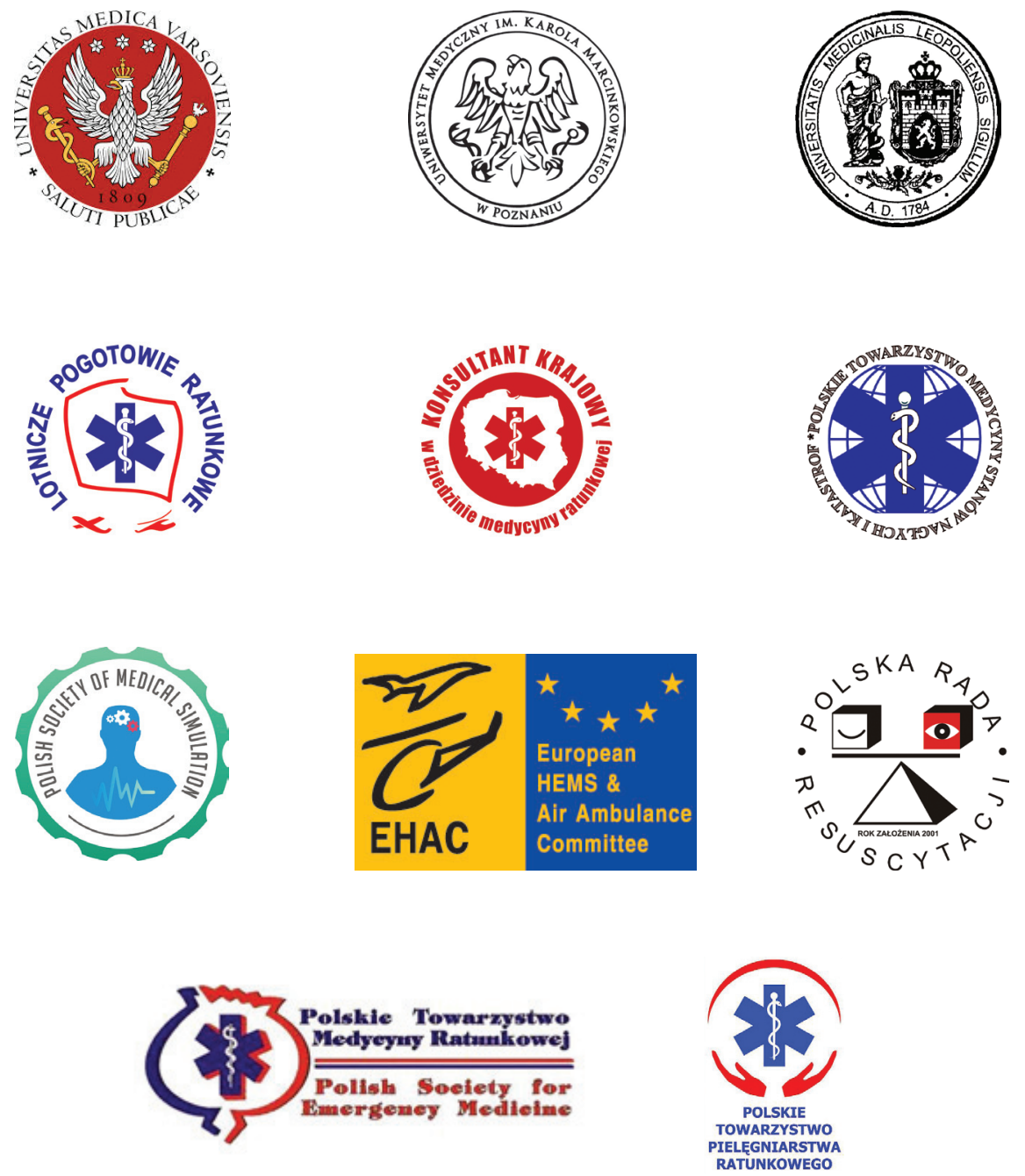


\section{Editorial Board}

\section{Editor in Chief \\ Robert Gałązkowski (Warsaw, Poland) \\ Associate Editor \\ Klaudiusz Nadolny (Katowice, Poland)}

Topic Editors

Dariusz Timler (Lodz, Poland)

- emergency medicine

Patryk Rzońca (Lublin, Poland)

- emergency medical service, simulation medicine

\section{Language Editors \\ Agnieszka Rosa \\ Thomas Drazba}

\section{Editorial Board}

Agata Dąbrowska (Poznan, Poland)

Marek Dąbrowski (Poznan, Poland)

Michael Hough (London, United Kingdom)

Mateusz Komza (Warsaw, Poland)

Kai Kranz (Nottwil, Switzerland)

Heidi Laine (Turku, Finland)

Bernd Lang (Vienna, Austria)

Thomas LeClair (Windsor, Canada)

\section{Scientific Board}

Janusz Andres (Cracow, Poland)

Carlos U. Arancibia (Virginia, USA)

David Baker (Paris, France)

Andrzej Basiński (Gdansk, Poland)

Odeda Benin-Goren (Tel Aviv, Israel)

Táňa Bulíková (Bratislava, Slovakia)

Michael Cassara (New York, USA)

Michael S. Czekajło (Virginia, USA)

Tomasz Darocha (Cracow, Poland)

Oryna Detsyk (Ivano-Frankivsk, Ukraine)

Adam Domanasiewicz (Trzebnica, Poland)

Artur Fedorowski (Malmo, Sweden)

Sergiy Fedorov (Ivano-Frankivsk, Ukraine)

Mark D. Frank (Dresden, Germany)

Michał Gaca (Poznan, Poland)

Ryszard Gajdosz (Cracow, Poland)

Wojciech Gaszyński (Lodz, Poland)

Mariusz Goniewicz (Lublin, Poland)

Roman Gřegoř (Ostrava, Czech Republic)

Arsen Gudyma (Tarnopol, Ukraine)

Przemysław Guła (Warsaw, Poland)

Kurihara Hayato (Milan, Italy)
Nataliya Izhytska (Lviv, Ukraine)

Rakesh Jalali (Olsztyn, Poland)

Sylweriusz Kosiński (Zakopane, Poland)

Dariusz Kosson (Warsaw, Poland)

Anthony J. LaPorta (Parker, USA)

Thomas LeClair (Windsor, Canada)

Piotr Leszczyński (Warsaw, Poland)

David Lockey (London, United Kingdom)

Hans Morten Lossius (Drobak, Norway)

Jerzy Robert Ładny (Bialystok, Poland)

Waldemar Machała (Lodz, Poland)

Konrad Meissner (Greifswald, Germany)

Olle Melander (Malmo, Sweden)

Grzegorz Michalak (Warsaw, Poland)

Marek Migdał (Warsaw, Poland)

Marcin Mikos (Cracow, Poland)

Franz Mikulcik (Vienna, Austria)

Piotr Misiak (Lodz, Poland)

Pavel Müller (Brno, Czech Republic)

Adam Nogalski (Lublin, Poland)

Okan Ozmen (Izmir, Turkey)

Gal Pachys (Jerusalem, Israel)
Linguistic Supervisor

Marek Siuta

\section{Statistical Editor/Redaktor statystyczny}

Ewa Guterman

\author{
Marek Maślanka (Cracow, Poland) \\ Paweł Panieński (Poznan, Poland) \\ Marcin Podgórski (Warsaw, Poland) \\ Adrian Stanisz (Cracow, Poland) \\ Artur Szela (Wroclaw, Poland) \\ Stanisław Świeżewski (Warsaw, Poland) \\ Edyta Wcisło (Lodz, Poland) \\ Arkadiusz Wejnarski (Warsaw, Poland)
}

Cezary Pakulski (Szczecin, Poland)

Volodymyr Pokhmurskii (Ivano-Frankovsk, Ukraine)

Małgorzata Popławska (Cracow, Poland)

Marek Rudnicki (Chicago, USA)

Tomasz Sanak (Cracow, Poland)

Pranas Šerpytis (Vilnius, Lithuania)

Zeynep Sofuoglu (Izmir, Turkey)

Krystyn Sosada (Zabrze, Poland)

Joanna Sowizdraniuk (Cracow, Poland)

Łukasz Szarpak (Warsaw, Poland)

David Thomson (Greenville, USA)

Kamil Torres (Lublin, Poland)

Štefan Trenkler (Kosice, Slovakia)

Arkadiusz Trzos (Cracow, Poland)

Bernard Wiśniewski (Warsaw, Poland)

Marzena Wojewódzka-Żelezniakowicz (Bialystok, Poland)

Richard Vincent (Brighton, United Kingdom)

Wolfgang Voelckel (Salzburg, Austria)

Andrzej Zawadzki (Warsaw, Poland)

Iwan Zozula (Kiev, Ukraine)

Dorota Zyśko (Wrocław, Polska)

Articles published on-line and available in open access are published under Creative Common Attribution - Non Commercial-No Derivatives 4.0 International (CC BY-NC-ND 4.0) allowing to download articles and share them with others as long as they credit the authors and the publisher, but without permission to change them in any way or use them commercially.

Copyright: ALUNA PUBLISHING

Z.M. Przesmyckiego 29

05-510 Konstancin-Jeziorna, Poland

tel. +48604776311

a.luczynska@wydawnictwo-aluna.p

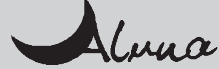

www.ems.edu.pl
Managing Editor

Agnieszka Rosa

tel. +48600600938

a.rosa@wydawnictwo-aluna.pl 


\section{CONTENTS}

\section{ORIGINAL ARTICLES}

Prognostic factors of chronic coronary syndrome in patients with concomitant type 2 diabetes mellitus

Nataliya Nyshchuk-Oliinyk, Sergiy Fedorov

Differences between end-tidal carbon dioxide obtained in right and left lateral decubitus positions in a patient with a pulmonary embolism - a concept for usage in emergency medicine

Dorota Zyśko, Grzegorz Gogolewski, Goutam Chourasia, Joanna Wizowska, Maciej Guziński,

Dariusz Jagielski, Dariusz Timler, Klaudiusz Nadolny....

The impact of changes on the efficiency of the hospital Emergency Department in Rybnik

Piotr Kuczera

Sudden cardiac arrest in patients over 60 years of age in the operation area of Emergency Medical Service in Siedlce in 2013-2017

Agnieszka Hawrylewicz-Łuka, Robert Gałazkowski, Daniel Celiński, Krzysztof Mitura Leszek Szpakowski,

Stawomir Pilip, Pawet Śwniarski, Klaudiusz Nadolny.

The assessment of work burnout and life satisfaction among nurses with the use of Copenhagen Burnout Inventory

Bianka Misiak, Jolanta Lewko, Regina Sierżantowicz, Karolina Lewko, Andrzej Guzowski,

Hady Razak Hady, Jerzy Robert Ładny

Acute Coronary Syndrome - Are we aware?

Mateusz Lech, Paulina Bakier, Sylwia Jabłońska, Rafał Milewski, Emilia Duchnowska, Jerzy Robert Ładny .

The analysis of sixth-year medicine students' knowledge of paramedics competencies and their field of work

Przemystaw Marek Fengler, Filip Jaśkiewicz

The knowledge of students of the faculty of medicine and the faculty of emergency medicine about intraosseous access

Tomasz Męcik-Kronenberg, Aleksandra Joanna Kuć, Katarzyna Krzyżak, Daria Małgorzata Kubik,

Klaudia Ewa Kościelecka

\section{REVIEW ARTICLES}

Sodium-glucose cotransporter-2 inhibitors as new strategy of chronic heart failure management

Andrii S. Herashchenko, Sergiy V. Fedorov

Triage and emergency medical management of the acute radiation syndrome

Arkadiusz Trzos, Wiktoria Kudła, Karol Łyziński

The use of survival techniques in rescue proceedings on the example of the use of medicinal plants

Łukasz Kucharski.

\section{CASE REPORTS}

Severe methemoglobinemia with unknown cause - case report

Małgorzata Rak, Michat Dworzyński, Michat Dudek, Tomasz Ilczak, Dariusz Timler, Pawet Krakowiak, Anna Krakowiak

The concept of damage control resuscitation (DCR) in the prehospital as well as in-hospital setting - a case report

Wojciech Stefaniak, Łukasz Rozbicki 


\title{
PROGNOSTIC FACTORS OF CHRONIC CORONARY SYNDROME IN PATIENTS WITH CONCOMITANT TYPE 2 DIABETES MELLITUS
}

\author{
Nataliya Nyshchuk-0liinyk, Sergiy Fedorov \\ IVANO-FRANKIVSK NATIONAL MEDICAL UNIVERSITY, IVANO-FRANKIVSK, UKRAINE
}

Abstract

Introduction: Chronic coronary syndrome (CCS) with concomitant type 2 diabetes mellitus (T2DM) is still a major cause of disability and mortality. That is why studying the prognostic factors of combination of these diseases is very relevant. There are many researches regarding the inflammation component of the development of atherosclerosis in patients with CCS and T2DM. It is still unknown how exactly does chronic systemic inflammation influences cardiac remodeling in such patients.

The Aim: Considering the aforementioned, the aim of our study was to asses the prognostic role of serum SST2, highsensitive C-reactive protein (hs-CRP) and TMAO as markers of chronic systemic inflammation and ins insulin resistance in patients with CCS and T2DM.

Material and methods: 90 patients were enrolled, among them 30 patients with CCS: stable angina, class II-III (group I) and 60 patients with CCS: stable angina, class II-III and T2DM, non-insulin-requiring (group II). The study was performed in Ivano-Frankivsk (entral City Hospital and City Hospital No 1 (Ukraine) in accordance with the Helsinki Declaration and Good Clinical Practice Guideline. All patients gave written informed consent and the local ethics committee approved the study protocol. The patients were tested for the following: glycated hemoglobin (HbA1c), total plasma cholesterol (TC), triglycerides (TG), high density lipoproteins (HDL), low and very low density lipoproteins (LDL and VLDL), TMA0, SST2, hs-CRP.

Results and discussion: Patients with CCS and concomitant T2DM have higher levels of markers of systemic inflammation response, including TMAO by 8.5 times, sST2 by 2.2, hs-CRP by 19.1, compared with healthy individuals.

Conclusions: Patients with CCS and concomitant T2DM have more "atherogenic" dyslipidemia compared with the patients with isolated CCS, including statistically significant higher levels of triglycerides $(p<0.05), \operatorname{VLDL}(p<0.05)$, and atherogenicity index of plasma (AIP) $(p<0.05)$, and lower level of $\operatorname{HDL}(p<0.05)$. Results of this study suggest the possible use of ST2 as diagnostic and prognostic marker in patients with stable angina, including patients with concomitant T2DM. ST2 level $>35 \mathrm{ng} / \mathrm{mL}$ is negative prognostic marker concerning the development of chronic heart failure and testament for the need of more thorough examination of such patients. The level of TMAO can also be another credible predictor of negative prognosis of CCS.
Key words

chronic coronary syndrome, type-2 diabetes mellitus, chronic inflammation, cardiovascular diseases, atherosclerosis

\section{INTRODUCTION}

Chronic coronary syndrome (CCS) with concomitant type 2 diabetes mellitus (T2DM) is one of the most important healthcare and social problems of modern society, which is due to high incidence and prevalence, frequent occurrence of micro- and macrovascular complications. Coronary artery disease (CAD) in patients with T2DM is observed 2-4 times more often than in patients with the same age, but without T2DM. Real number of patients with T2DM in Ukraine is approximately 2-2.5 million, which is an important healthcare concern regarding the cardiovascular disease (CVD) incidence.

According to the Framingham study, even after adjustments were made (age, smoking, blood pressure level, total serum cholesterol level), the presence of T2DM increased the risk of CAD by $66 \%$ in men and by $20.3 \%$ in women. The MRIFT study (Multiple Risk Factor Intervention Trial), which enrolled a relatively large number of middle-age patients $(n=5163)$, gave further information regarding interaction of T2DM and other risk factors of total CVD risk. Therefore, T2DM is an independent risk factor. The presence of other risk factors in men with T2DM significantly increases the 12-year death from CVD risk.

Results of epidemiological studies prove that the risk of coronary complications and sudden cardiac death in patients with CCS and concomitant T2DM is 3 times higher than in patients with CCS and without T2DM and vice versa. According to the metanalysis of 37 prospective studies, the risk of cardiac death associated with T2DM is $50 \%$ higher in women than in men [1]. 
In recent years there were published new clinical and experimental data based on the assessment of inflammation markers (C-reactive protein, certain pro-inflammatory cytokines, serum amyloid A, haptoglobin, fibrinogen, etc.), that support the role of systemic or chronic inflammation as a pathogenetic mechanism of coronary atherosclerosis development [2]. The first objective is to study the influence that inflammatory component has on atherosclerosis development in patients with CCS and concomitant T2DM. It is still unknown, exactly what effect does chronic systemic inflammation have on cardiac remodeling. Recently, the role of interleukin 33 in atherogenesis was researched. Interleukin 33, a receptor to which is ST2 (growth STimulation expressed gene 2), exists in 2 main isoforms (transmembrane isoform ST2L, that takes part in Th-2-dependanet cascade, and serum isoform sST2). ST2 - is a novel marker, which is used for prognosis and stratification of risk of the development of heart failure (HF), negative consequences and death in patients with confirmed HF, development of CVD in the future. Some studies on the animals show, that the level of sST2 is not just a biomarker, but an important protective signaling system which activates in case of a CVD, including CCS and T2DM [3].

Also, the new factors of atherogenesis were discovered: a study performed by group of scientis of Cleveland University proved the connection between the high level of trimethylamine $\mathrm{N}$-oxide and increased risk for the atherosclerosis development and progression [4-6].

\section{THE AIM}

Considering the aforementioned, the aim of our study was to assess the prognostic role of serum sST2, high-sensitive C-reactive protein (hs-CRP) and TMAO as markers of chronic systemic inflammation and ins insulin resistance in patients with CCS and T2DM.

\section{MATERIAL AND METHODS}

90 patients were enrolled, among them 30 patients with CCS: stable angina, class II-III (group I) and 60 patients with CCS: stable angina, class II-III and T2DM, non-insulin-requiring (group II). The study was performed in Ivano-Frankivsk Central City Hospital and City Hospital No 1 (Ukraine) in accordance with the Helsinki Declaration and Good Clinical Practice Guideline. All patients gave written informed consent and the local ethics committee approved the study protocol.
Mean age of patients was $56.35 \pm 1.36$ years, including: of men $-53.20 \pm 1.22$ years, of women $-61.70 \pm 1.88$ years. Mean age of women from the group with stable angina was $61.50 \pm 1.23$ years, of men $-56.70 \pm 2.30$ years, and from the group with stable angina and T2DM $-61.46 \pm 1.75$ years and $54.44 \pm 1.23$ years respectively, which shows, that by the gender structure the patients were equal.

The diagnosis of CCS and stable angina was made according to the present recommendations established in the ESC guidelines [7], and the diagnosis of T2DM - according to ADA [8].

Serum glucose was evaluated by glucose oxidase method; fasting glycated hemoglobin - by the ion chromatography method. Total serum cholesterol and triglycerides levels were assessed by "Lachema" diagnostic kits. High density lipoproteins were determined in supernatant after precipitation of low density and very low density lipoproteins (LDL and VLDL) with the following analysis by S. Ilka method. The level of LDL was determined by W.T. Friedwald formula: LDL $=$ TC-(TGx2.29/5+HDL). The level of triglycerides was evaluated by the same formula. The normal ranges were the following: TC $-4.72 \pm 0.16 \mathrm{mmol} / \mathrm{L}, \mathrm{TG}-1.12 \pm 0.09 \mathrm{mmol} / \mathrm{L}, \mathrm{LDL}$ - $3.80 \pm 0.02 \mathrm{mmol} / \mathrm{L}, \mathrm{HDL}-1.13 \pm 0.10 \mathrm{mmol} / \mathrm{L}$. The levels of sST2 and hs-CRP were determined by enzyme-linked immunosorbent assay. The evaluation of the level of TMAO was performed in the laboratory "Diameb". The d9-marked trimethylamine $\mathrm{N}$-oxide was used during the preparation of the test. The test analysis was performed in liquid chromatograph mass spectrometer Shimadzu 8050 (Japan) with electrodispersion ionization. Chromatographic component dispersion was done by the method of hydrophilic chromatography. The calibration curve was a linear relationship of the concentration range $50-10000 \mathrm{ng} / \mathrm{mL}$, the lower limit of quantification was $50 \mathrm{ng} / \mathrm{mL}$.

Statistical analysis was performed using Statistica 10 and «Microsoft Excel» statistical function package on personal computer. The variational statistical analysis was used. We calculated the arithmetic mean $\mathrm{M}$, standard deviation $\delta$, mean arithmetic error $m$, sample size (n), probability value «p», value $\mathrm{p}<0.05$ was considered as statistically significant. Correlational analysis was performed with the use of Pearson's correlation coefficient (rxy). 


\section{RESULTS AND DISCUSSION}

Table 1. Blood lipid values in patients with stable angina type 2 diabetes mellitus $(\mathrm{M} \pm \mathrm{m})$.

\begin{tabular}{|c|c|c|c|c|}
\hline \multicolumn{2}{|c|}{ Value } & $\begin{array}{l}\text { Healthy individuals } \\
\qquad(n=15)\end{array}$ & $\begin{array}{l}\text { Group I } \\
\text { Stable angina } \\
(n=30)\end{array}$ & $\begin{array}{c}\text { Group II } \\
\text { Stable angina/T2DM } \\
(n=60)\end{array}$ \\
\hline \multirow{3}{*}{\multicolumn{2}{|c|}{$\begin{array}{l}\text { TC } \\
{[\mathrm{mmol} / \mathrm{L}]}\end{array}$}} & $4.51 \pm 0.16$ & $6.52 \pm 0.13$ & $6.65 \pm 0.17$ \\
\hline & & & $\mathrm{p}_{1}<0.001$ & $\mathrm{p}_{1}<0.001$ \\
\hline & & & & $\mathrm{p}_{2}>0.05$ \\
\hline \multirow{3}{*}{\multicolumn{2}{|c|}{$\begin{array}{l}\text { TG } \\
{[\mathrm{mmol} / \mathrm{L}]}\end{array}$}} & $1.30 \pm 0.12$ & $1.66 \pm 0.11$ & $2.06 \pm 0.12$ \\
\hline & & & $\mathrm{p}_{1}<0.02$ & $\mathrm{p}_{1}<0.001$ \\
\hline & & & & $\mathrm{p}_{2}<0.02$ \\
\hline \multirow{2}{*}{\multicolumn{2}{|c|}{$\begin{array}{l}\mathrm{HDL} \\
{[\mathrm{mmol} / \mathrm{L}]}\end{array}$}} & $1.24 \pm 0.06$ & $0.95 \pm 0.09$ & $0.59 \pm 0.06$ \\
\hline & & & $p_{1}<0.01$ & $p_{1}<0.01$ \\
\hline \multirow{4}{*}{\multicolumn{2}{|c|}{$\begin{array}{l}\mathrm{LDL} \\
{[\mathrm{mmol} / \mathrm{L}]}\end{array}$}} & & & $\mathrm{p}_{2}<0.05$ \\
\hline & & $2.59 \pm 0.16$ & $5.7 \pm 0.13$ & $5.98 \pm 0.18$ \\
\hline & & & $\mathrm{p}_{1}<0.001$ & $\mathrm{p}_{1}<0.001$ \\
\hline & & & & $\mathrm{p}_{2}<0.05$ \\
\hline Notes: & $\begin{array}{l}\text { 1. } p \\
\text { 2. } p\end{array}$ & $\begin{array}{l}\text { gnificance of difference } \\
\text { gnificance of difference }\end{array}$ & $\begin{array}{l}\text { son with healthy persons; } \\
\text { son with CCS group. }\end{array}$ & \\
\hline
\end{tabular}

Table 2. Values of systemic inflammation markers (sST2, hs-CRP, TMAO) in patients with stable angina and T2DM (M $\pm \mathrm{m})$.

\begin{tabular}{|c|c|c|c|}
\hline Value & $\begin{array}{l}\text { Healthy individuals } \\
\qquad(n=15)\end{array}$ & $\begin{array}{c}\text { Group I } \\
\text { Stable angina } \\
\quad(n=30)\end{array}$ & $\begin{array}{c}\text { Group II } \\
\text { Stable angina/T2DM } \\
(n=60)\end{array}$ \\
\hline \multirow{3}{*}{$\begin{array}{l}\mathrm{sST2} \\
{[\mathrm{ng} / \mathrm{mL}]}\end{array}$} & $15.84 \pm 0.45$ & 22251.95 & 34222.73 \\
\hline & & $\mathrm{p}_{1}<0.01$ & $\mathrm{p}_{1}<0.001$ \\
\hline & & & $\mathrm{p}_{2}<0.05$ \\
\hline \multirow{3}{*}{$\begin{array}{l}\text { hs-CRP } \\
{[\mathrm{mg} / \mathrm{mL}]}\end{array}$} & 0.680 .01 & 6230.15 & 12932.07 \\
\hline & & $\mathrm{p}_{1}<0.001$ & $\mathrm{p}_{1}<0.001$ \\
\hline & & & $\mathrm{p}_{2}<0.001$ \\
\hline \multirow{3}{*}{$\begin{array}{l}\text { TMAO } \\
{[\mathrm{ng} / \mathrm{mL}]}\end{array}$} & $120.22 \pm 9.27$ & $676.53 \pm 14.48$ & $1022.91 \pm 80.73$ \\
\hline & & $\mathrm{p}_{1}<0.001$ & $\mathrm{p}_{1}<0.001$ \\
\hline & & & $\mathrm{p}_{2}<0.001$ \\
\hline Notes: & $\begin{array}{l}\text { gnificance of differenc } \\
\text { gnificance of differenc }\end{array}$ & $\begin{array}{l}\text { n with healthy persons; } \\
\text { n with CCS group. }\end{array}$ & \\
\hline
\end{tabular}

It was established, that in patients with stable angina, regardless of comorbidity, the level of total serum cholesterol was higher $(\mathrm{p}<0.001)$ than in healthy persons, group $1(6.25 \pm 0.13) \mathrm{mmol} / \mathrm{L}$ and group 2 $(6.65 \pm 0.17) \mathrm{mmol} / \mathrm{L}$, the limit of normal range was $(4.51 \pm 0.16) \mathrm{mmol} / \mathrm{L}$ (Table 1). Same changes were observed regarding the level of atherogenic LDL, the limit of normal range was $(2.59 \pm 0.16) \mathrm{mmol} / \mathrm{L}$, in patients form group 1 was $(5.27 \pm 0.13) \mathrm{mmol} / \mathrm{L}$, from group $2(5.98 \pm 0.18) \mathrm{mmol} / \mathrm{L}(\mathrm{p}<0.01)$. The level of triglycerides in serum of the patients with stable angina was also significantly higher than in healthy persons. Moreover, if patients from group 1 had tryglicerides level of $(1.66 \pm 0.11) \mathrm{mmol} / \mathrm{L}$, then patients from group $2(2.06 \pm 0.12) \mathrm{mmol} / \mathrm{L}$, which is statistically significant than in healthy individuals and patients without T2DM.

We discovered, that the level of ST2 in patients with stable angina and T2DM (34 222.73) ng/mL was higher than in patients with stable angina only (22 251.95) ng/mL ( $<<0.05)$. Analyzing the level of ST2 in enrolled patients, we found a different result in men and women (26.6-44.4 and 16.7-33.0 ng/mL adjusted by age respectively) (Table 2). Therefore, the elevated level of this biomarker was dependent of age, presence of T2DM and hypertension. Results of our study correspond with the opinion of B. Dieplenger et al., who studied the serum level of ST2 in patients with stable coronary artery disease and had a selective coronary angiography [9]. 
The results of our study show, that patients with comorbidity (CCS and T2DM) had 19.01 times higher level of serum hs-CRP (12 932.07) than healthy persons $(\mathrm{p}<0.05)$, and 2.08 times than patients from group $1(\mathrm{p}<0.05)$. Patients with stable angina and without T2DM had 9.12 time higher level of serum hs-CRP than healthy individuals $(\mathrm{p}<0.05)$. Therefore, in our opinion, the assessment of hs-CRP has big prognostic value and proves the activation of systemic inflammatory process on the background of T2DM.

When we compared the level of TMAO in patients with stable angina concomitant with T2DM and stable angina only, we found 1.5 times increase of this marker. Mean concentration of TMAO $(\mathrm{M} \pm \mathrm{m})$ in enrolled patients with stable angina and T2DM comorbidity the level of TMAO was $1022.91 \pm 80.73$ $\mathrm{ng} / \mathrm{mL}$, the patients with stable angina only in comparison had concentration of $676.53 \pm 14.48 \mathrm{ng} / \mathrm{mL}$ $(\mathrm{p}<0.001)$.

TMAO is a metabolite of phosphatidylcholine and L-carnitine, which is present in red meat, egg yolk, milk, liver, which all are basic components of patients diet [10]. Pathological influence of TMAO on cardiovascular system consists of several pathways. Several recent studies showed, that high level of TMAO influences the cholesterol and sterol metabolism through the increase of mRNA expression of cholesterol transporters (Abca1, Srb1 and Abcg1), and subsequent interference in cholesterol reuptake inhibition and development of atherosclerosis [11].
Also, TMAO can facilitate cholesterol storage in macrophages, with their subsequent transformation in foam cells, by the increase of expression on the surface of macrophages of proatherogenic phagocyte (scavenger) receptors CD36 and A (SRA) [12], which in turn causes the increase of number of foam cells and the development of atherosclerotic plaque. TMAO is viewed as one of the markers of instability of atherosclerotic plaque, which causes the development of thrombosis of both coronary artreies, as well as cerebral arteries [13].

\section{CONCLUSIONS}

1. Patients with CCS and concomitant T2DM have more "atherogenic" dyslipidemia compared with the patients with isolated CCS, including statistically significant higher levels of triglycerides $(p<0.05)$, VLDL $(p<0.05)$, and atherogenicity index of plasma (AIP) $(\mathrm{p}<0.05)$, and lower level of $\operatorname{HDL}(\mathrm{p}<0.05)$.

2. Results of this study suggest the possible use of ST2 as diagnostic and prognostic marker in patients with stable angina, including patients with concomitant T2DM. ST2 level $>35 \mathrm{ng} / \mathrm{mL}$ is negative prognostic marker concerning the development of chronic heart failure and testament for the need of more thorough examination of such patients.

3. The level of TMAO can also be another credible predictor of negative prognosis of CCS.

\section{REFERENCES}

1. Korkushko OV, Lugovskoy EV, Shatilo VB, et al. Age features of the hemostatic system in people with insulin resistance and prediabetic carbohydrate metabolism disorders. Adv Gerontol. 2015;5(4): 303-309.

2. Ostanina YO, Yakhontov DA, Zvonkova AV, Zhuravleva II, Dunicheva OV, Yakhontova PK. Systemic inflammation in patients with hypertension and coronary artery disease in different age groups. Siber Med J. 2019;34(3):97-102. (Published in Russian)

3. Kop'Eva KV, Teplyakov AT, Grakova EV, Soldatenko MV, Ogurkova ON, Ahmedov SD. Role of ST2 biomarker for the evaluation of myocardial remodeling in patients with ischemic heart failure with preserved ejection fraction. Kardiologiia. 2018;58(10S):33-43. (Published in Russian)

4. Mente A, Chalcraft K, Ak H, et al. The relationship between trimethylamine-N-oxide and prevalent cardiovascular disease in a multiethnic population living in Canada. Canad J Cardiol. 2015;31(9): 1189-1194.

5. Senthong, Vichai, Wang Z, Li XS, et al. Intestinal microbiota-generated metabolite trimethylamine$\mathrm{N}$-oxide and 5-year mortality risk in stable coronary artery disease: the contributory role of intestinal microbiota in a COURAGE-like patient cohort. J Am Heart Assoc 2016;5(6):e002816.

6. Liu TX, Niu HT, Shu-Yang, Zhang SY. Intestinal microbiota metabolism and atherosclerosis. Chin Med J. 2015;128(20):2805.

7. Knuuti J, Wijns W, Saraste A, et al. 2019 ESC Guidelines for the diagnosis and management of chronic coronary syndromes: The Task Force for the diagnosis and management of chronic coronary syndromes of the European Society of Cardiology (ESC). Eur Heart J. 2020;41(3):407-477

8. American Diabetes Association. Standards of Medical Care in Diabetes - 2020. Diabetes Care 2020;43(Suppl. 1):S66-S76 
9. Dieplinger B, Egger M, Haltmayer M, et al. Increased soluble ST2 predicts long-term mortality in patients with stable coronary artery disease: results from the Ludwigshafen risk and cardiovascular health study. Clin Chem. 2014;60(3):530-540.

10. Blesso CN. Egg phospholipids and cardiovascular health. Nutrients 2015;7(4):2731-2747.

11. Koeth RA, Wang Z, Levison BS, et al. Intestinal microbiota metabolism of L-carnitine, a nutrient in red meat, promotes atherosclerosis. Nat Med. 2013;19(5):576.

12. Senthong V, Li XS, Hudec T, et al. Plasma trimethylamine N-oxide, a gut microbe-generated phosphatidylcholine metabolite, is associated with atherosclerotic burden. J Am Coll Cardiol. 2016;67(22):2620-2628.

13. Liu, X, Xie Z, Sun M, et al. Plasma trimethylamine N-oxide is associated with vulnerable plaque characteristics in CAD patients as assessed by optical coherence tomography. Int J Cardiol. 2018;265: 18-23.

ORCID AND CONTRIBUTIONSHIP*

Nataliya Nyshchuk-Oliinyk

$-0000-0002-4338-6121$ A, B, , C, D,E,F

Sergiy Fedorov - 0000-0002-2202-4279 A, B, , , D,E,F,

\section{CONFLICT OF INTEREST}

Authors declare no conflict of interest.

\section{ADDRESS FOR CORRESPONDENCE}

Sergiy Fedorov

Ivano-Frankivsk National Medical University

Ivano-Frankivsk, Ukraine

2 Halytska Str., Ivano-Frankivsk, 76018,

Ukraine

e-mail: serfed@i.ua 


\title{
DIFFERENCES BETWEEN END-TIDAL CARBON DIOXIDE OBTAINED IN RIGHT AND LEFT LATERAL DECUBITUS POSITIONS IN A PATIENT WITH A PULMONARY EMBOLISM - A CONCEPT FOR USAGE IN EMERGENCY MEDICINE
}

\author{
Dorota Zyśko', Grzegorz Gogolewski', Goutam Chourasia', Joanna Wizowska', Maciej Guziński², \\ Dariusz Jagielski ${ }^{3}$, Dariusz Timler ${ }^{4}$, Klaudiusz Nadolny ${ }^{5,6}$ \\ 1 DEPARTMENT OF EMERGENCY MEDICINE, WROCLAW MEDICAL UNIVERSITY, WROCLAW, POLAND \\ 2 DEPARTMENT OF RADIOLOGY, WROCLAW MEDICAL UNIVERSITY, WROCLAW, POLAND \\ 3 DEPARTMENT OF CARDIOLOGY, CENTRE FOR HEART DISEASE, $4^{\text {TH }}$ MILITARY HOSPITAL, WROCLAW, POLAND \\ 4 DEPARTMENT OF EMERGENCY MEDICINE AND DISASTER MEDICINE, MEDICAL UNIVERSITY OF LODZ, LODZ, POLAND \\ 5 DEPARTMENT OF EMERGENCY MEDICAL SERVICE, STRATEGIC PLANNING UNIVERSITY OF DABROWA GORNICZA, DABROWA \\ GORNICZA, POLAND
}

6 FACULTY OF MEDICINE, KATOWICE SCHOOL OF TECHNOLOGY, KATOWICE, POLAND

\section{Abstract}

The aim: To diagnose patients with suspected pulmonary embolism is to assess etCO $\mathrm{C}_{2}$ in two lateral decubitus positions and to compare them between each other and with $\mathrm{PaCO}_{2}$.

Material and methods: An approval of the bioethics commission was obtained to study eTCO in different positions in patients with suspected PE (583/2019). Consecutive ED patients referred for computed tomography pulmonary angiography (CTPA) due to a suspicion of pulmonaryartery embolism areasked to take partin thestudy. Exclusion criteria are the inability to giveinformed consent, shock or hypotension, inability to change position (an elevation of the upper body to 30 degrees is allowed). The other available laboratory data like D-dimer concentration, troponin, arterial blood gases analysis, creatinine, sodium, potassium, NT-proBNP, hemoglobin, C-reactive protein, and glycemia are noted. CTPA in the case of pulmonary embolism is assessed to determine differences between embolism to both lungs.

Results: The difference between eTCO${ }_{2}$ on the left lateral decubitus position was found. Contrary to this finding in a healthy person there was no differences between e $\mathrm{TCO}_{2}$ obtained in both lateral positions. Stress tests are known methods for examining patients whose underlying conditions are normal or inconclusive. In the case of capnography, such a load could be a change in body position, which is a simple procedure that does not require much physical effort. Conclusions: Intensifying efforts to disseminate knowledge on the use of eTCO in clinical practice and to find new applications for this study seems particularly important.

\section{INTRODUCTION}

Pulmonary embolism (PE) is a common disease. The diagnosis of PE is one of the most difficult clinical problems. The gold standard of PE diagnosis is a pulmonary artery computed tomography (CTPA) [1]. However, the radiologic examination is expensive and not easily available, especially in outpatient settings.

Capnography is a non-invasive diagnostic method that evaluates carbon dioxide $\left(\mathrm{CO}_{2}\right)$ partial pressure in respiratory gases. The $\mathrm{CO}_{2}$ partial pressure in expelled air changes over the respiratory cycle and obtains the highest value at the end of expiration (end-tidal $\mathrm{CO}_{2}, \mathrm{eTCO}_{2}$ ). ETCO $\mathrm{ET}_{2}$ related to $\mathrm{CO}_{2}$ production in tissues, lung perfusion, alveolar ventilation, and respiratory patterns [2].

In hemodynamically stable patients with normal metabolism, eTCO 2 is about 3-5 $\mathrm{mmHg}$ lower than partial pressure of $\mathrm{CO}_{2}$ in arterial blood $\left(\mathrm{PaCO}_{2}\right)$ and the difference represents dead space ventilation [3]. This dead space ventilation is increased in PE due to ventilation of alveoli which are not perfused but are ventilated. A proposal of the use of capnography in the diagnosis of pulmonary embolism was presented by Robin et al. in their pivotal paper "A physiological approach to the diagnosis of acute pulmonary embolism" in 1959 [4]. Decreased eTCO 2 was regarded as 
a sign of pulmonary embolism with high sensitivity, however, specificity is not so high because low e $\mathrm{TCO}_{2}$ could have a pulmonary aetiology through pulmonary hypoperfusion during shock or increased dead space ventilation due to lung diseases. A meta-analysis of studies evaluating capnography as a diagnostic tool for pulmonary embolism was performed in 2013 by Manara et al. [5]. The authors found that normal eTCO $\mathrm{T}_{2}$ might be useful for the exclusion of pulmonary embolism with patients with pretest probability less than $10 \%$ and positive $\mathrm{D}$ dimer. However, it should be stressed that current guidelines do not recommend nor do they even mention the use of capnography to exclude pulmonary embolism. However, low $\mathrm{eTCO}_{2}$ is proposed as an abnormal finding during cardiopulmonary exercise testing for the assessment of long term sequel of PE [1].

Lateral decubitus position is known to impair ventilation/perfusion $(\mathrm{V} / \mathrm{Q})$ relationship due to reduced ventilation of dependent lung and overventilation of nondependent lung [6].

\section{THE AIM}

The proposed supplementary manoeuvre to diagnose patients with suspected pulmonary embolism is to assess $\mathrm{eTCO}_{2}$ in two lateral decubitus positions and to compare them between each other and with $\mathrm{PaCO}_{2}$.

\section{METHODS}

An approval of the bioethics commission was obtained to study $\mathrm{eTCO}_{2}$ in different positions in patients with suspected PE (583/2019).

The capnography obtained in a patient with PE in different positions was presented.

\section{RESULTS AND DISCUSSION}

In the Figure 1 a representative recording obtained during left and right lateral decubitus position is presented. e $\mathrm{TCO}_{2}$ was low. The difference between $\mathrm{eTCO}_{2}$ on the left lateral decubitus position was found. Contrary to this finding in a healthy person there was no differences between $\mathrm{TCO}_{2}$ obtained in both lateral positions.

Low eTCO $\mathrm{T}_{2}$ occurs when the anatomic or physiologic dead space increases. Former may be caused by the presence of an open ventilator circuit and shallow breathing. Later may result from the presence of regions ventilated but not sufficiently perfused in obstructive lung disease, excessive lung inflation, in low cardiac output conditions, and in pulmonary embolism [6].

Lying on the one side decreases the chest movements of this site what in emergency medicine is used to stabilize chest with unilaterally broken ribs. Therefore, the ventilation on this side is diminished. In the case of thromboses in the pulmonary arteries on the same side that a patient is lying, the ventilation of the lung with lower dead space results in an increase in eTCO ${ }_{2}$. Contrary, lying on the opposite site leads to a decrease in $\mathrm{eTCO}_{2}$ because ventilation increase in the lung with increased dead space.

The other reason for the difference between $\mathrm{eTCO}_{2}$ between positions could result from changes in respiratory rate.

The symmetrical emboli to both pulmonary arteries may abolish this relationship, however, usually the emboli are not equally distributed.

Other authors reported that placing a healthy anesthetized patient in lateral decubitus position increases $\mathrm{eTCO}_{2}$, because the dependent lung function is diminished and $\mathrm{PaCO}_{2}$ increases concomitantly [7].

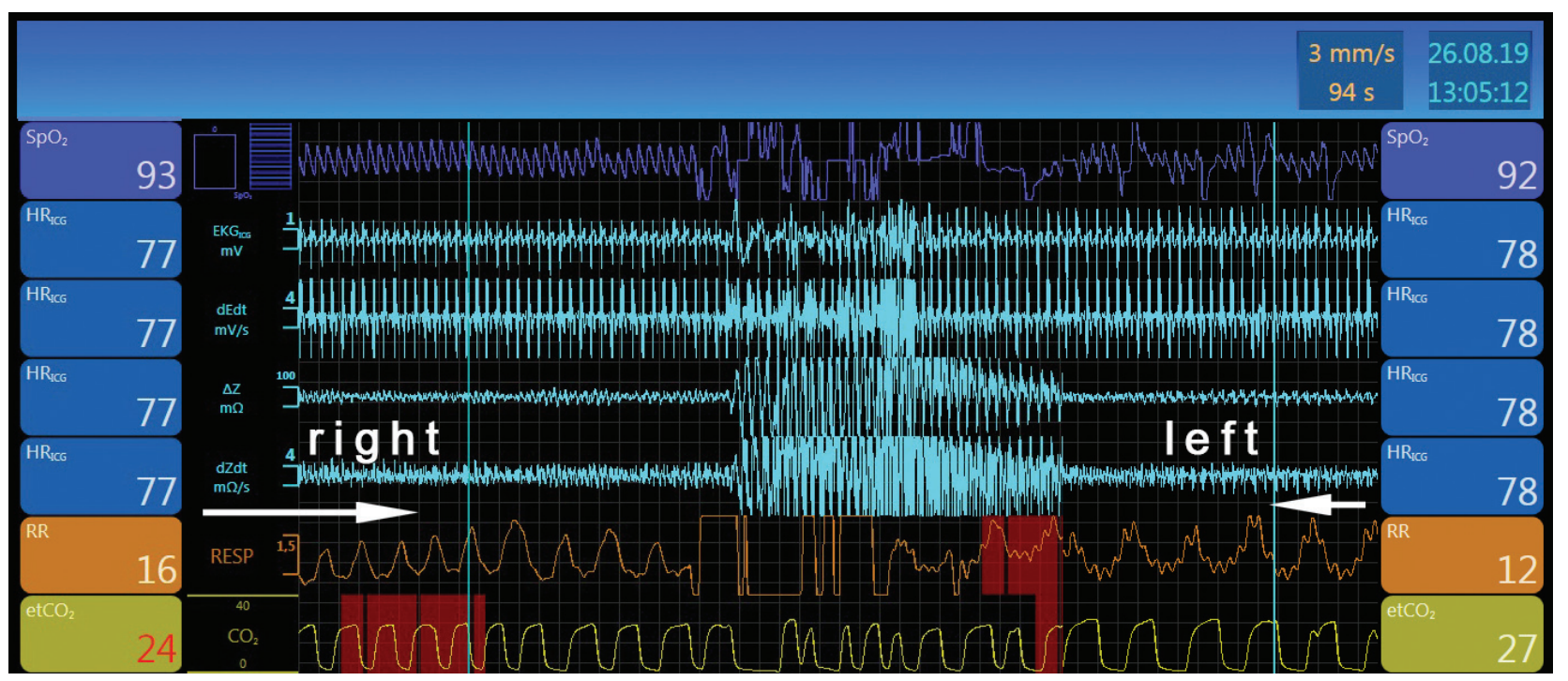

Fig 1. The recording obtained during left and right lateral decubitus position. 
Therefore, decrease $\mathrm{eTCO}_{2}$ on lateral position in comparison to supine position is an abnormal finding. The differences between values obtained in both lateral positions probably are not specific for PE. However, such a result indicates the problem related to the lungs and the necessity to perform a further diagnostic evaluation. Therefore, the finding could be important in prehospital environment. Low $\mathrm{eTCO}_{2}$ and the presence of difference in $\mathrm{eTCO}_{2}$ in the clinical context of hemodynamically stable patients is a red flag and indicates the necessity for further assessment and treatment. Therefore, the presented findings may be of interest and require further examination.
Stress tests are known methods for examining patients whose underlying conditions are normal or inconclusive. In the case of capnography, such a load could be a change in body position, which is a simple procedure that does not require much physical effort. Recently, the Minister of Health issued an ordinance regarding the supply of EMS with devices enabling measurement of $\mathrm{eTCO}_{2}$. For this reason, the test available so far mainly for anaesthesiologists is becoming available to a wide range of people involved in the treatment of patients who are at risk of life and health. Therefore, intensifying efforts to disseminate knowledge on the use of e $\mathrm{TCO}_{2}$ in clinical practice and to find new applications for this study seems particularly important.

\section{REFERENCES}

1. Konstantinides SV, Meyer G, Becattini C, et al. The Task Force for the diagnosis and management of acute pulmonary embolism of the European Society of Cardiology (ESC). 2019 ESC Guidelines for the diagnosis and management of acute pulmonary embolism developed in collaboration with the European Respiratory Society (ERS): The Task Force for the diagnosis and management of acute pulmonary embolism of the European Society of Cardiology (ESC). Eur Respir J. 2019 Oct 9;54(3).

2. Long B, Koyfman A, Vivirito MA. Capnography in the Emergency Department: A Review of Uses, Waveforms, and Limitations. J Emerg Med. 2017 Dec;53(6):829-842.

3. McSwain SD, Hamel DS, Smith PB, Gentile MA, Srinivasan S, Meliones JN, Cheifetz IM. End-tidal and arterial carbon dioxide measurements correlate across all levels of physiologic dead space. Respir Care. 2010 Mar;55(3):288-93.

4. Robin ED, Julian DG, Travis DM, Crump CH. A physiologic approach to the diagnosis of acute pulmonary embolism. N Engl J Med. 1959 Mar 19;260(12):586-91.

5. Manara A, D'hoore W, Thys F. Capnography as a diagnostic tool for pulmonary embolism: a meta-analysis. Ann Emerg Med. 2013 Dec;62(6):584-91.

6. Kodali BS. Capnography outside the operating rooms. Anesthesiology. 2013 Jan;118(1):192-201.

7. Mahajan S, Chauhan R, Luthra A, Bala I, Bharti N, Sharma A. Evaluation of Arterial to End-tidal Carbon Dioxide Pressure Differences during Laparoscopic Renal Surgery in the Lateral Decubitus Position. Anesth Essays Res. 2019 Jul-Sep;13(3):583-588.

\section{ORCID AND CONTRIBUTIONSHIP *}

Dorota Zyśko - 0000-0001-9190-0052 A,F

Grzegorz Gogolewski - 0000-0002-1806-9028 B,C

Goutam Chourasia - 0000-0002-7903-788X A,E

Joanna Wizowska - 0000-0001-8746-1341 C,E

Maciej Guzinski - 0000-0002-9781-2114 D,E

Dariusz Jagielski - 0000-0003-2239-7216 E,F

Dariusz Timler - 0000-0002-5415-5660 C,E

Jerzy Robert Ładny - 0000-0003-4167-1962 E,F

Klaudiusz Nadolny - 0000-0003-0355-241X B, D
RECEIVED

22.07.2020

\section{FOUNDING}

Wroclaw Medical University SUB.A280.19.049

Dorota Zyśko

ADDRESS FOR CORRESPONDENCE

Katedra i Klinika Medycyny Ratunkowej

Uniwersytet Medyczny we Wrocławiu

ul. Borowska 213, 50-556 Wrocław, Poland

e-mail: dzysko@wp.pl

\section{CONFLICT OF INTEREST}

Authors declare no conflict of interest.
ACCEPTED

02.09.2020

*Contribution: A - Work concept and design, B-Data collection and analysis, C - Responsibility for statistical analysis, D-Writing the article, E-Critical review, F-Final approval. 


\title{
THE IMPACT OF CHANGES ON THE EFFICIENCY OF THE HOSPITAL EMERGENCY DEPARTMENT IN RYBNIK
}

\author{
Piotr Kuczera ${ }^{1,2}$ \\ 1 HOSPITAL EMERGENCY DEPARTMENT, PROVINCIAL SPECIALIST HOSPITAL NO. 3 IN RYBNIK, RYBNIK, POLAND \\ 2 EMERGENCY MEDICAL SERVICE STATION IN RYBNIK, PROVINCIAL EMS IN KATOWICE, RYBNIK, POLAND
}

\section{Abstract}

The aim: The continuous development of medical sciences, the progress of aging of the population, and the increase in the number of accidents constantly force the management of emergency departments (ED) to adopt the conditions in the ward by focusing on the effective protection of patients presenting to the hospital. The subject undertaken in this work was to determine the effectiveness of changes in the daily functioning of the hospital ED in Rybnik from 2017.

Material and methods: The research used numerous literature items as well as normative acts defining the legal conditions of the State Emergency Medical Service (EMS) system. Unpublished materials, owned by the Provincial Specialist Hospital No. 3 in Rybnik, played an important role. In addition, the method of diagnostic survey was applied with the use of the survey technique (a questionnaire): the direct survey conducted among employees of the hospital ED.

Results: In the survey, respondents assessed changes in the work organization of the hospital ED, including the introduction of 24-hour duty for emergency medicine specialists, the introduction of a scheduled admission room as well as the introduction of patient's initial assessment with a separate room for the initial assessment of children. Most of the respondents' assessments were above the average.

Conclusions: This information is optimistic and expresses the positive attitude of the employees of the ED in Rybnik to the changes introduced in the unit, and thus to increasing the efficiency of the daily work of the hospital ED in Rybnik.

\section{Key words \\ quality, \\ improvement, \\ standardization, \\ effect}

\section{INTRODUCTION}

The hospital Emergency Department (ED) is the element of the state Emergency Medical Service (EMS) system providing emergency healthcare to patients in a state of sudden health and life threat. According to the definition, it is an organizational unit of a hospital within the meaning of the provisions on medical activity [1], and it provides healthcare services to people in a state of emergency, meeting the requirements set out in the Act and Regulations to the Act on EMS [2]. The activities performed in the ED include services which, due to the patient's health condition, require immediate diagnostics and treatment, and, if necessary, also include transport to a specialized unit in order to maintain continuity of treatment [3-4]. In the hospital ED:

- every patient has the right to immediate medical services if their health or life is at risk,

- it does not matter whether the person in need of medical help at the ED came alone or was brought by the EMS,

- medical help is provided in the first place to people who require immediate stabilization of basic life activities, or to women in the event of childbirth,
- every presenting patient is admitted, regardless of the place of residence [5].

Currently, there are 14 hospital EDs in the Silesian Voivodeship, which provide health care services, on a 24-hour basis, consisting of initial diagnostics and starting treatment to the extent necessary to stabilize the vital functions of people who are in a state of sudden health threat [6-7]. Hospital EDs concentrate the most important principles of hospital work as if in a lens - they are a kind of "hospital within a hospital". The efficiency of the hospital ED's work affects, first of all, the safety of patients, but also the quality of work of the entire treatment facility [8]. It is in this zone that matters of life and death are at stake. It accommodates patients of all age groups with various, more or less serious, diseases. It is a particularly important space in the context of relieving the stress of patients and their families, but also of personnel working in extremely difficult conditions for the psyche [9].

According to the recommendations of the minister of health and the national emergency medicine consultant, the minimum number of personnel in the ED should be:

a. 3-4 doctors permanently residing in the $\mathrm{ED}$, covering a population of $150,000-200,000$ inhabitants, 
b. 10 paramedics or system nurses permanently residing in the ED, covering a population of 150,000 200,000 inhabitants,

c. auxiliary staff at the ED (e.g. registrars, stretchbearers, cleaning staff),

d. 2 medical segregation stations (TRIAGE) [10].

Hospital EDs should be located in accordance with the current number of residents, the forecast number of residents, as well as in the hospital having at least:

a. a general surgery ward with a trauma part, and in the case of hospitals providing health services for children - a pediatric surgery ward,

b. an internal medicine ward, and in the case of hospitals providing health services for children a pediatric ward,

c. department of anesthesiology and intensive care,

d. diagnostic imaging laboratory [11-12].

In accordance with the Regulation of the minister of health regarding the hospital ED, this unit is internally divided into separate, functionally different areas. Among them there are: the area of medical segregation (TRIAGE), registration and admissions; resuscitation and treatment area; initial intensive care area; observation area; consultation area; administrative and economic area; area where emergency medical teams are stationed (optional - if the department has emergency medical teams) and a landing pad for rescue helicopters [13]. The Hospital ED in Rybnik is functionally divided into:

- general area,

- surgical and orthopedic area,

- observation area with 4 beds,

- hospital information.

The individual areas of the ED in Rybnik - in accordance with the Regulation of the minister of health on the hospital ED, include individual sectors required by the executive act, such as:

- In the general area, a consultation area and an area of medical segregation for children are specified,

- In the surgical and orthopedic area, the following areas are distinguished: medical segregation for adults, resuscitation and treatment, initial intensive therapy, immediate therapy and administrative and economic facilities,

- In hospital information - the area of registration and admissions [14].

In the general area of the ED, the diagnostic and therapeutic process takes place in patients presenting with various diseases from various branches of medicine: internal medicine, cardiology, laryngology, ophthalmology, gynecology and obstetrics, neurology, and pediatrics.

In the surgical and trauma area, patients are treated by specialists in the field of trauma and orthopedic surgery, general surgery, pediatric surgery and urology.

Supervision over the work of the department is performed by the head, the coordinator, and the ward nurse and the coordinating nurse. Outside the normal hours of hospital ordination, i.e. on duty (on weekdays from 15:00-7:00 and 24/7 on weekends and holidays), in the absence of the management staff, this function is performed by an emergency medicine specialist on a given duty [15].

Each patient presenting to the ED or transferred by EMS teams or Sanitary Transport teams reports to medical segregation (adults - for adults, children - for children, respectively). In turn, in the TRIAGE room, the initial assessment of the examined person takes place, after which the patient is admitted to the ED in accordance with the ICD-10 code (corresponding to the disease or injury with which he or she came) and the name of the doctor on duty who, in accordance with his specialization, plans the diagnostic and therapeutic process of the patient. Subsequently, the doctor examines the patient, makes recommendations regarding the implementation of pharmacotherapy or diagnostic laboratory and imaging tests, followed by the treatment process. Patients requiring treatment for up to 24 hours are transported to the observation area. After completing the diagnostic and therapeutic process in the $\mathrm{ED}$, the physician treating the patient prepares an information card of hospital treatment and, if necessary, prescriptions or referrals to a specialist clinic / department in order to continue the treatment process.

In 2017 , a total of 36,443 patients were admitted to the ED of the Provincial Specialist Hospital No. 3 in Rybnik, including:

- 11,386 women,

- 25,798 men,

- 14,954 children.

From January to December 2017, 31,644 patients were discharged from the ED of the Provincial Specialist Hospital No. 3 in Rybnik, 34 died, and the remaining 4,765 patients were transferred to another ward to continue the treatment process [16].

\section{THE AIM}

The subject matter undertaken in the work was to determine the effectiveness of changes in the daily functioning of the hospital ED in Rybnik from 2017. As a part of the research, an analysis of the effectiveness of changes regarding the implementation of 
health services provided in the surveyed unit was carried out. These modifications were correlated with a partial change of the management of the Rybnik ED.

\section{MATERIAL AND METHODS}

The research was carried out in the hospital ED which is a unit of the Provincial Specialist Hospital No. 3 in Rybnik. The assessment of changes to the effectiveness of the ED were carried out in terms of the impact of changes on the organization of work and the quality of healthcare services. The research was carried out on the basis of data obtained from questionnaires completed by employees of the ED, as well as information provided by the Provincial Specialist Hospital No. 3 in Rybnik. The information contained in the paper relates to 2017 and 2018. The research was performed in the first quarter of 2018 .

The following research methods were used in the study:

- literature studies,

- analysis of the number of patients admitted to Provincial Specialist Hospital No. 3 in Rybnik,

- classic method of comparisons describing the differences in the functioning of the emergency department.

In order to obtain information, the research was carried out using the diagnostic survey method with the use of the survey technique and the use of the tool - a survey questionnaire:

- direct survey - conducted among employees of the ED in Rybnik.

\section{RESULTS}

100 respondents, including 35 men and 65 women, took part in the study. All professional groups working in the ED were encouraged to participate in the study. Paramedics constituted the most numerous group of respondents, more than half -52 people. The next, less numerous groups were equally nurses/male nurses and doctors -22 people in each of them. The fewest respondents were stretch-bearers -4 people. The age of the respondents ranged between 23 and 52 years. Paramedics and doctors were the professional group with the least experience in the ED in Rybnik. 24 paramedics and 12 doctors were working for less than a year, while 15 paramedics and 6 doctors were working between 2 and 5 years. This trend was declining. In the 6-10 years of work category in the ED there are 13 paramedics and 4 doctors. And no one from the aforementioned professional groups had experience exceeding 10 years. Two nurses worked less than a year, 4 nurses were in the range of 2-5 years and 12 - in the range of $6-10$ years. Nurses were by far the most experienced in the ED - 4 people had more than 10 years of work experience. Among the stretch-bearers, all respondents (4 people) had work experience in the ED in the range of 2-5 years.

At the beginning of the study, the staff of the ED were asked whether in their opinion it was justified to create the position of a coordinating nurse/paramedic in the ED area during a 12-hour duty. The answers were given in the 0-1 system (yes or no). The obtained results, according to individual professional groups, are presented in Figure 1. We concluded that

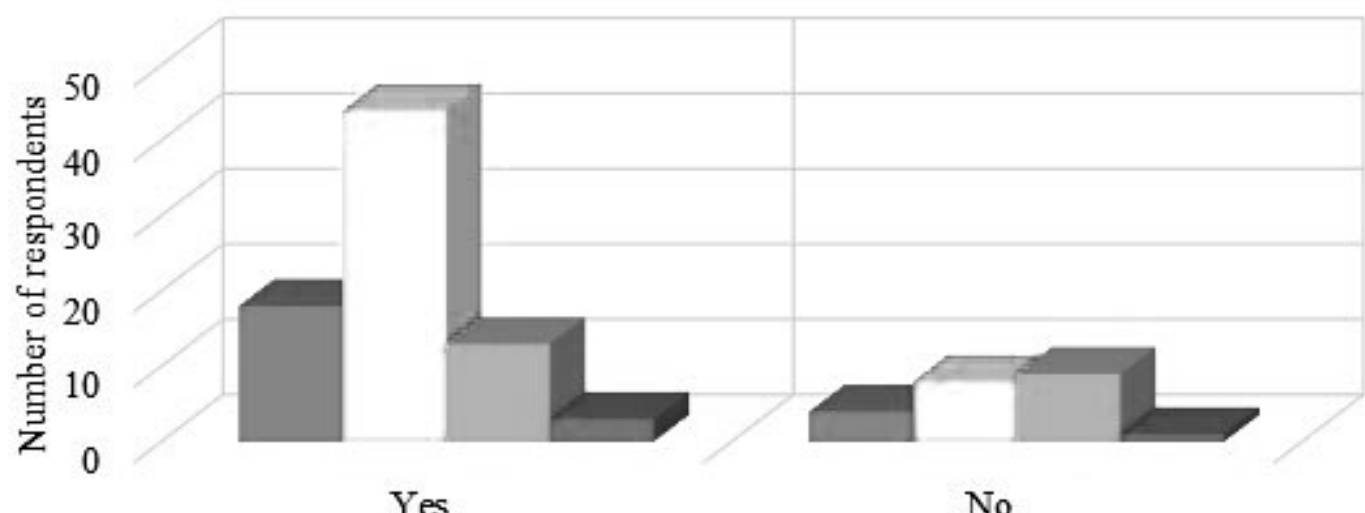

Type of assessment

\section{noctor $\square$ Paramedic $\square$ Nurse $\square$ Orderly}

Fig. 1. Assessment of the legitimacy of creating the position of a coordinating nurse / paramedic in the ED area during a 12-hour duty - according to professional groups. 


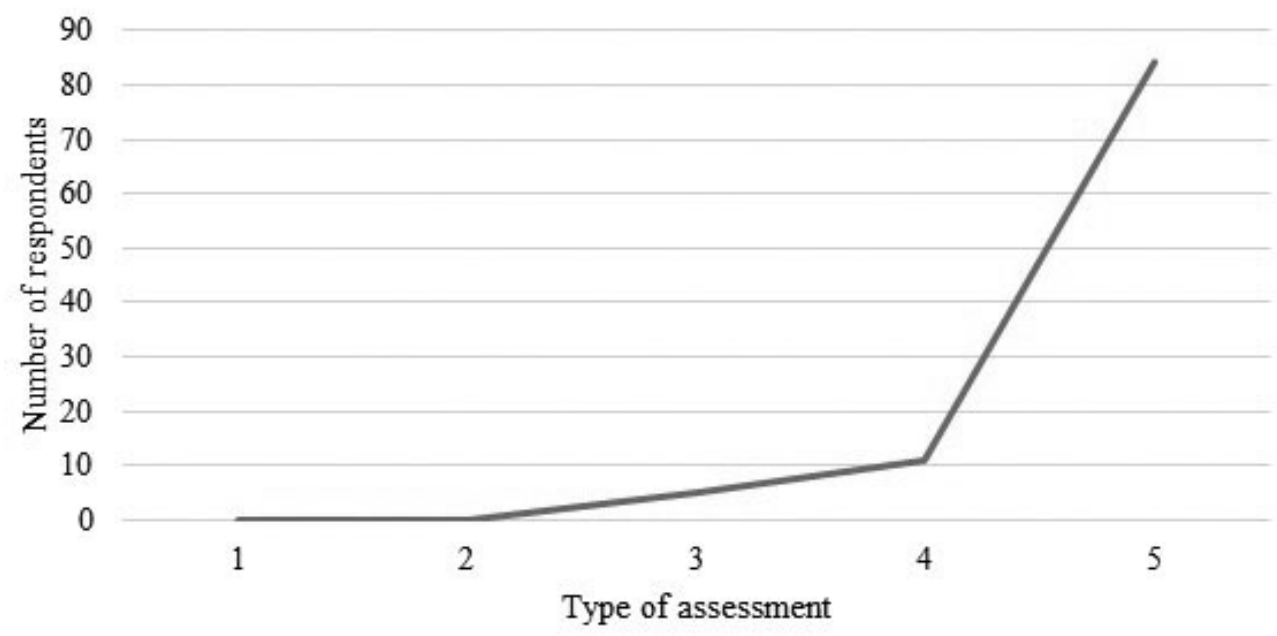

\section{- Number of ratings}

Fig. 2. Assessment of the introduction of emergency medicine specialists on duty in the ED.

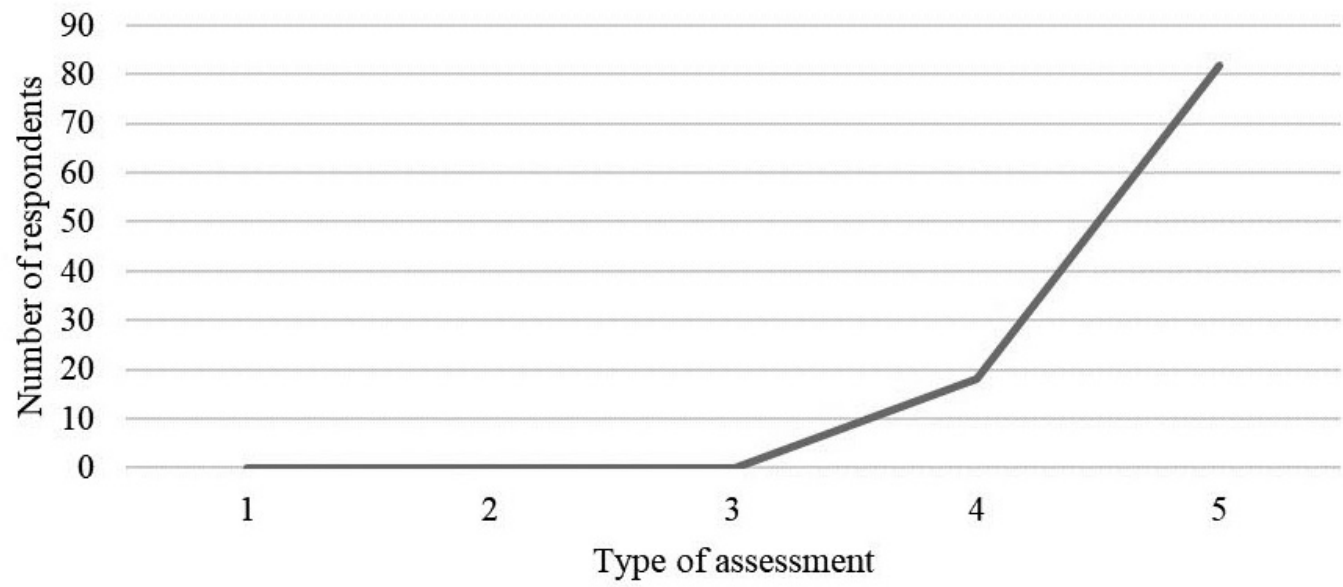

Number of ratings

Fig. 3. Assessment of the introduction of the Scheduled Admission Room.

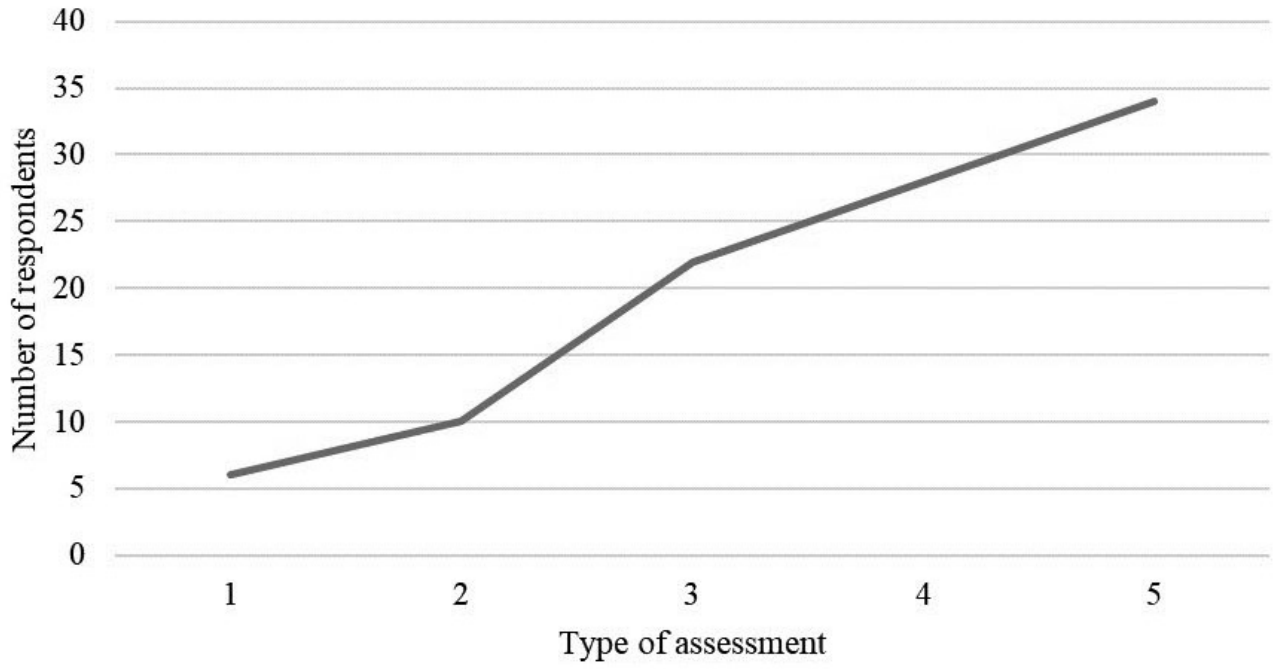

Number of ratings

Fig. 4. Assessment of the introduction of the initial patient assessment. 
most respondents answered the question positively (78 people). Of these people, there were 18 doctors, 44 paramedics, 13 nurses and 3 stretch-bearers. Only 22 people denied the legitimacy of establishing the position of a coordinating nurse/paramedic in the ED area during the 12-hour duty. In this group there were 8 paramedics, 9 nurses, 4 doctors and 1 stretch-bearer.

Further, the respondents were asked questions for which the response was assessed on a scale of 1-5, where 1 meant bad and 5 - very good. The examined changes concerned:

I. The introduction of a 24-hour duty for emergency medicine specialists in the ED.

The respondents' opinion is presented in Figure 2. As shown in the chart above, it can be seen that most respondents ( 84 people) assessed the introduction of 24-hour emergency medicine specialist duty in the ED very well. Eleven of the respondents assessed this change as good and 5 sufficiently.

II. The introduction of the Scheduled Admission Room.

The assessment of the respondents is presented in Figure 3. As can be seen in the chart above, all respondents rated the introduction of the Scheduled Admission Room above average. 82 people rated it very good and 18 people - good.

III.The introduction of initial patient assessment (TRIAGE) for adults.

The test results are shown in Figure 4. As the graph shows, it can be seen that the adult TRIAGE rating is increasing. The highest number of opinions obtained by the respondents were very good (34). Successively good opinions stand for 28 people, sufficient -22 people, mediocre -10 people and bad -6 people.
IV. The introduction of periodic and free trainings for the staff of the ED.

The results of the obtained research are presented in Figure 5. Based on the obtained results, we can conclude that most respondents -68 people rated this very well. On the other hand, 20 people supported the free training courses introduced for the employees of the ED. None of the respondents gave the answer "bad" or "mediocre" about the examined feature.

V. Increasing the number of nursing and paramedic personnel.

The obtained results are presented in Figure 6. As can be seen in the chart, 85 respondents assessed the increase in the number of working staff very positively. In turn, 10 people marked the answer good, 3 - satisfactory and 2 - mediocre.

VI. Establishment of a new resuscitation area with initial intensive care beds.

The summary of the obtained results is presented in Figure 7. As can be seen from the above chart, almost all respondents gave an above-average answer to the question about the formation of a new resuscitation area with intensive care beds. Out of the study group, 79 people rated it very good and 14 people rated it good. Only 7 people were sufficiently informed about the planned change.

VII. Establishment of a computed tomography laboratory at the ED.

The collected results are presented in Figure 8. As shown in the figure above, it can be seen that the highest number of assessments regarding the examined feature were very good (74). Eight people characterized it well, and 11 assessed the question about the planned formation of a computed tomography laboratory in the ED as satisfactory. Only 7 people gave a mediocre rating.

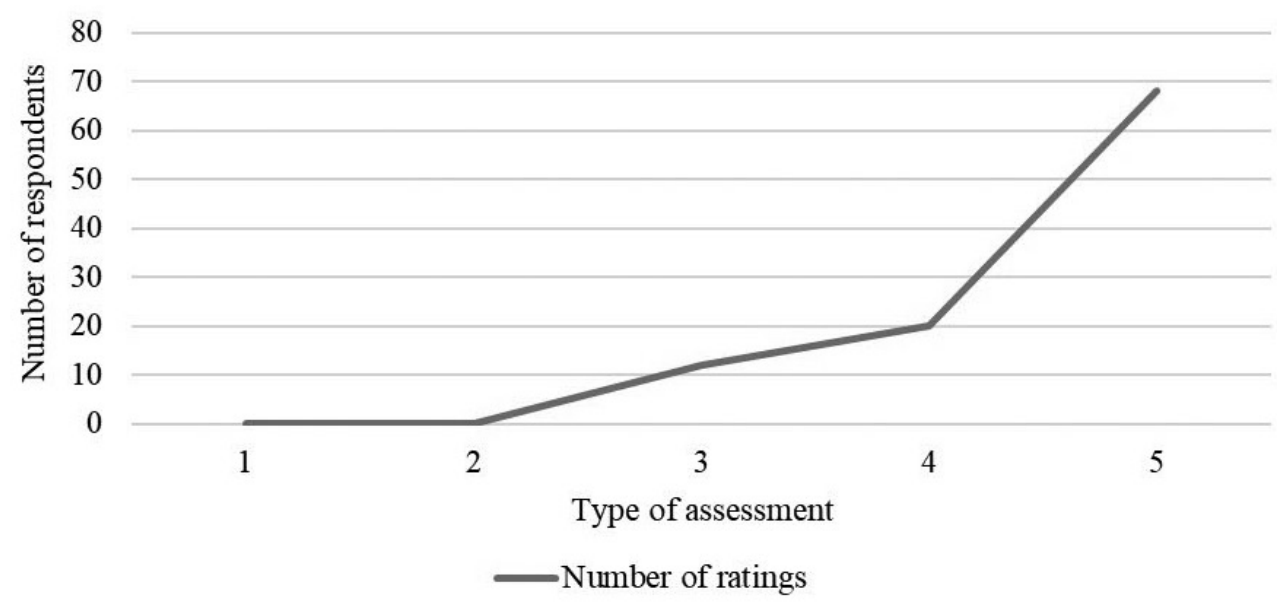

Fig. 5. Assessment of the introduction of periodic and free training for the staff of the ED. 


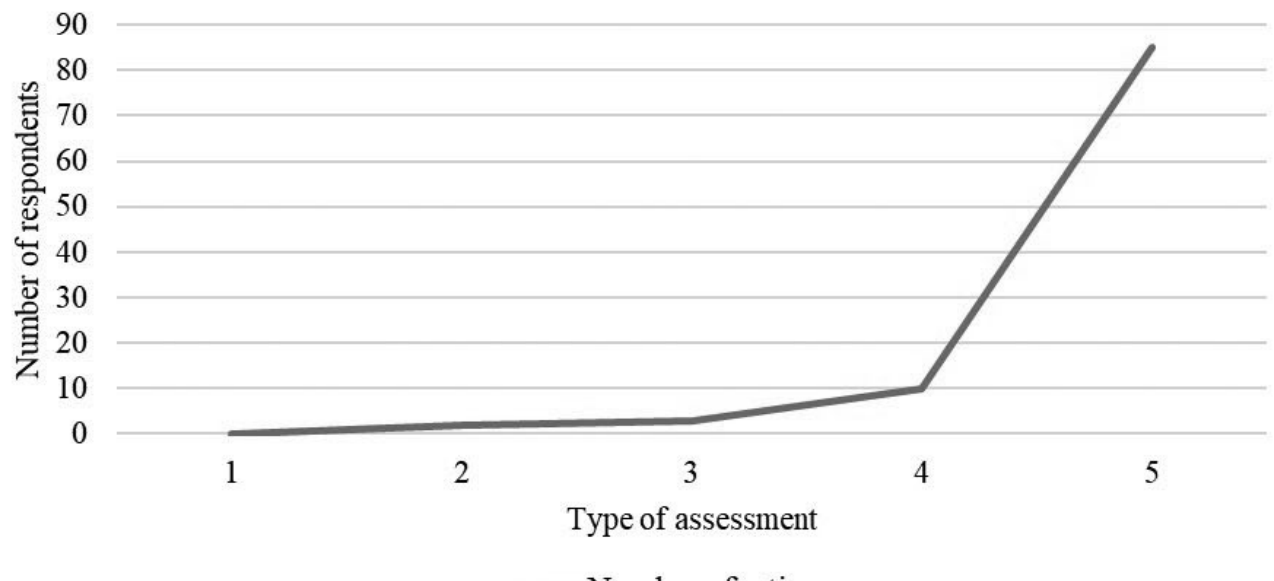

Fig. 6. Assessment of the increase in the number of nursing and paramedic personnel working in the ED.

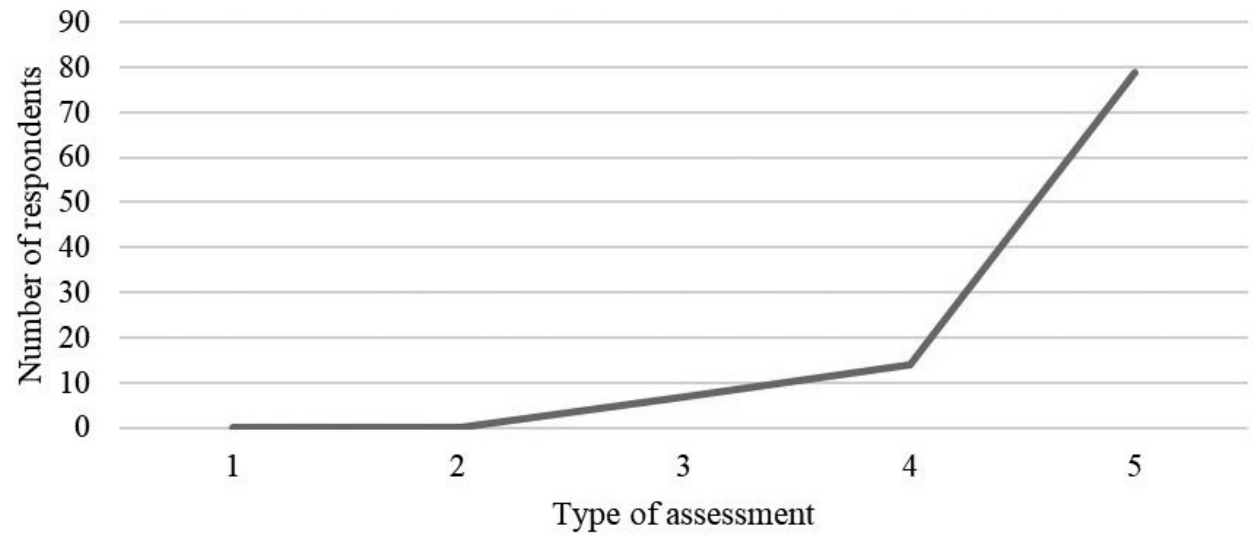

Number of ratings

Fig. 7. Assessment of the formation of a new resuscitation area with beds for initial intensive care.

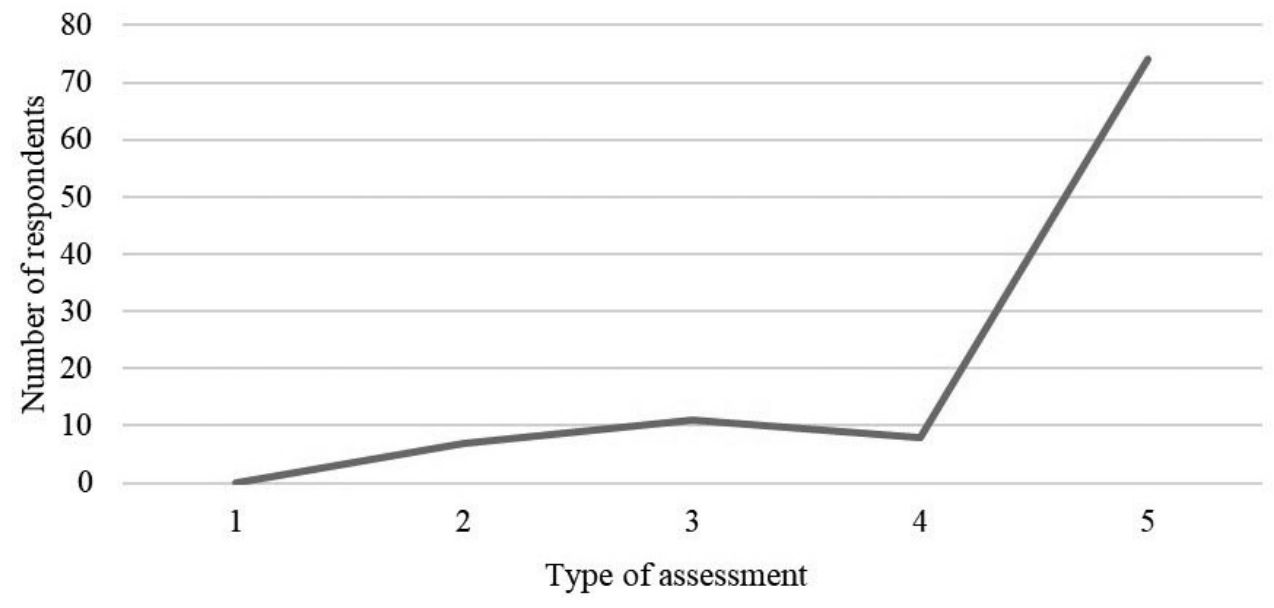

Number of ratings

Fig. 8. Assessment of the creation of a computer tomography laboratory in the ED. 


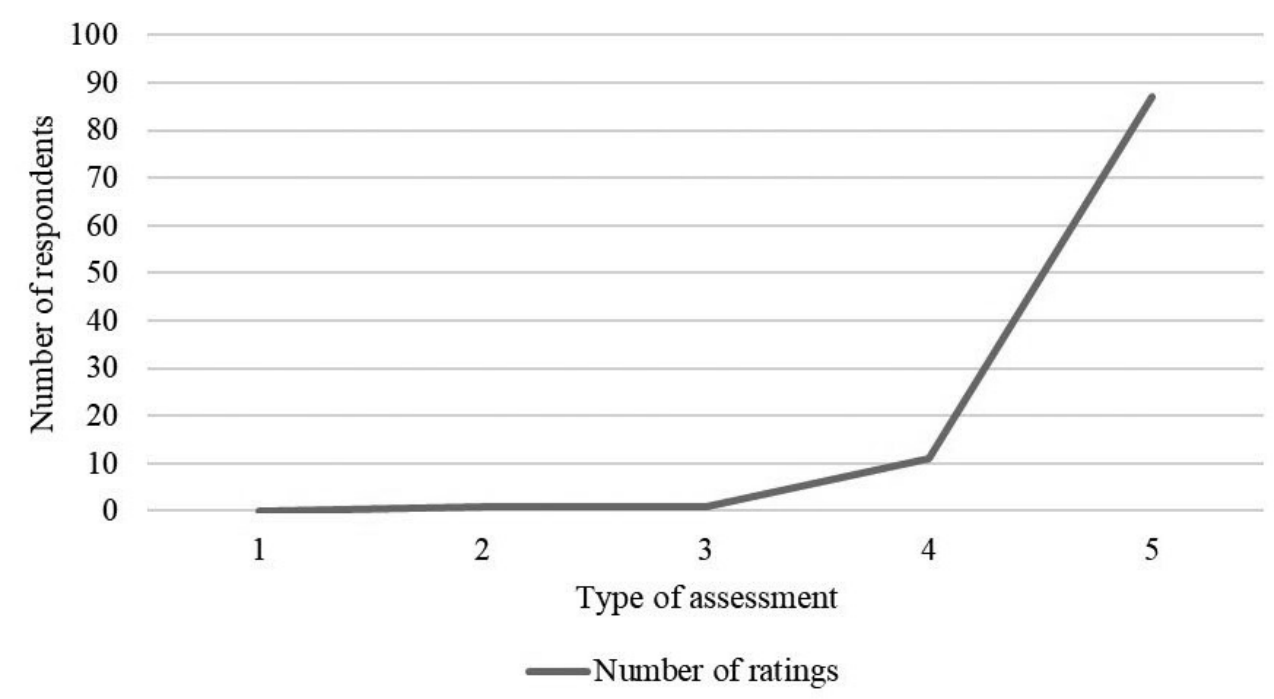

Fig. 9. Assessment of the creation of the preliminary assessment room with a waiting room adapted for children.

VIII. Establishment of an area of medical segregation with a separate waiting room for children.

The summary of the obtained results is presented in Figure 9. As it follows from the chart, most respondents were very positive about the change. Of these, 11 respondents defined their assessment as good, and one as satisfactory and mediocre.

\section{DISCUSSION}

At the beginning of the study, the respondents assessed the formation of a paramedic/nurse coordinator function in the 12-hour duty at the ED. The tasks of the area coordinator during a given on-call duty include resolving disputes among the nursing and rescue personnel, resolving conflicts between the personnel and the patient, as well as the distribution of duties between individual employees of the area, working during a given 12-hour duty. This position is an unprecedentedly great idea because it allows one to avoid unnecessary conflicts and maintain the best functionality of the department - and thus provide health services to the highest standard.

A significant change in the daily functioning of the ED was the introduction of the initial patient assessment for adults. In this regard, the method of transferring the patient from EMS teams to the ED also changed. Previously, the patient's condition was orally communicated to the doctor on duty, who was ultimately to deal with the diagnostic and therapeutic process. Due to the large number of patients, EMS teams often had to wait up to an hour before the patient was referred to a specific doctor. Another issue was how the doctor treated the patient. It happened that the physician on duty at the ED stated that the patient should be referred to another specialist, claiming that the
EMS misdiagnosed the patient. This extended the stay of the EMS teams at the ED, and thus the inability to dispatch them to subsequent calls. Since the inception of TRIAGE, EMS teams hand over the patient to a paramedic or nurse who performs an initial assessment. This situation significantly shortened the waiting time of EMS teams at the ED.

Emergency medicine specialization is a field assigned to the EDs and specialist EMS teams. Currently, there are few specialists in this field of medicine in the Silesian Voivodeship. The continuous, 24-hour presence of an emergency medicine specialist on duty gives the Rybnik ED a leading position in relation to other emergency care facilities in the Silesian Voivodeship.

Another aspect considered in the study was the establishment of a scheduled admission room. Before the introduction of this sector, all patients admitted to hospital wards reported to the ED. There, a medical history was created, the patient changed clothes and was led by a paramedic to the target ward. This situation was very chaotic in the daily functioning of the department. Among the patients in a state of sudden health emergency, there were chronically ill patients who often waited in a queue of several years for admission to a specific ward. Currently, such patients report to the Scheduled Admission Room, which definitely decreases the burden of the ED staff.

Initial patient assessment at the Rybnik ED was introduced in the first quarter of 2017. Currently, paramedics - rarely nurses - work in this area. Many people said that it was completely unnecessary. One year after its introduction, the opinion of many employees about the initial assessment changed. The initial negative attitude turned neutral and even posi- 
tive. It can be assumed that this is the result of a reluctance to introduce any news. In this case, this was the initial assessment of the patient.

From the beginning of 2017, the staff of the ED may voluntarily participate in training workshops in the field of emergency medicine and techniques used in EMS. One of such trainings was the free Improvement Course for Paramedics. It is worth mentioning that each paramedic is obliged to perform this 6-day training periodically every 5 years. Unfortunately, in most cases the cost of participation in such workshops is about PLN 500-1100.

The idea of increasing the number of ED personnel is mainly the idea of increasing the number of paramedics working in the ED. From the beginning of 2017, paramedics employed on an employment contract, as well as paramedics transferred to the ED from other hospital departments, started work. This situation allows to increase the manpower of the 12hour duty:

- from 3 to 5 people in the surgical and orthopedic area,

- from 4 to 6 people within the general area,

- from 1 to 2 people in the hospital information.

This phenomenon undoubtedly allows the acceleration of the provision of health services performed within the ED.

Employees who were working in the ED for many years had to adapt to the new functioning of the ward. In most cases, one could often hear complaints about the rules introduced, the way of daily work, new procedures. As the research shows, experienced employees still highly rated the introduced changes in the functioning of the ED. On the other hand, employees who were employed in the ED in or after 2017 started working immediately under the new rules. Therefore, it was easier for them to accept the modern way of functioning of the ED.

The resuscitation area with beds for the initial intensive care was created by arranging a free, not useful earlier space between the general and surgical and orthopedic sectors. This allowed better cooperation between the staff of individual parts of the ED while providing care to a patient in a life-threatening condition. Moreover, it is closer to other areas of the ED than before.

The creation of the computer tomography laboratory significantly facilitated and accelerated the imaging diagnostics of patients hospitalized in the ED. Previously, each computed tomography examination required the patient to be transported to the imaging diagnostics facility, located on the 2nd floor of the hospital building. Such a situation not only extended the time to perform the tomography, but also required the involvement of more personnel, necessary to transport the patient to higher floors of the building.

In the ED in Rybnik on duty there are, among others, pediatricians and pediatric surgery specialists. For this reason, many little patients come to the ED every day. It was therefore important to create a separate preliminary assessment room for children, fully adapted, colored - according to the needs of young patients. A stay in a hospital is very often a traumatic experience for a child. The toddler is concerned that this visit may be related to the pain they will experience. Therefore, the time spent in the ED should be as pleasant as possible for young patients. A big step in this direction was the creation of a separate waiting room and a play area for children. The second, equally important issue are other patients in the ED. They are often people under the influence of alcohol, behaving offensively and vulgarly. In order to protect the youngest from this, the management of the ED created a separate room for them. As can be seen from the data presented, the staff of the ED was very much in line with this idea.

\section{CONCLUSIONS}

Every day, the ED deals with a huge number of patients and many, sometimes complicated, ailments and injuries. The problem of optimizing the functioning of ED has thus become a subject of wide interest for emergency medicine specialists, people in charge of hospital activities and experts in the field of public health. The ED is undoubtedly a specific operating center for the entire hospital. As the main entrance leading to hospitalization in hospital wards, it is therefore also the showcase of the entire medical entity.

In the Rybnik ED, the changes were aimed at increasing quality and speeding up and standardization of methods of providing health services as a part of treatment processes conducted in the ED. These banners became the focus of the new management of the ED, which was partially changed in early 2017 .

During the research, the respondents assessed changes in the work organization of the ED. In each question concerning this part of the survey, most respondents' opinions were positive. Employees of the Rybnik ED who participated in the study assessed positively and above average the changes introduced in the daily functioning of the unit. Moreover, the respondents noticed a good impact of the changes on the diagnostic and therapeutic process, claiming that the innovative solutions accelerated the admission of patients to the ED, increased the complexity of their protection, which resulted in a better therapeutic ef- 
fect and increased safety of patients visiting the Rybnik treatment facility.

It can therefore be concluded that the ED employees bestowed the unit's management with a credit of trust, giving a positive opinion on the planned mod- ernizations. This information is optimistic and expresses the positive attitude of the employees of the ED in Rybnik to the changes introduced in the unit, and thus to increasing the efficiency of the daily functioning of the ED in Rybnik.

\section{REFERENCES}

1. Ustawa z dnia 15 listopada kwietnia 2011 r. o działalności leczniczej. Dz.U.2011 nr 112; poz. 654.

2. Ustawa z dnia 8 września 2006 r. o Państwowym Ratownictwie Medycznym. Dz. U. Nr 191; poz. 1410 ze zm.

3. Brongel L. Złota godzina - czas życia, czas śmierci. Kraków: Wydawnictwo Medyczne; 2007.

4. Plantz Scott H, Wipfler EJ. Medycyna ratunkowa NMS. Wrocław: Edra Urban \& Partner; 2018.

5. Jakubaszko J. Szpitalny Oddział Ratunkowy - organizacja i zadania. Ogolnopol Przegl Med. 2013;4:40-45.

6. Wojewódzki Plan Działania Systemu Państwowe Ratownictwo Medyczne. Urząd Wojewódzki w Katowicach. Katowice; 01. 04. 2019 r.

7. Kisiała W. Organizacja przestrzenna zmiany dostępności szpitalnych oddziałów ratunkowych w Polsce. Zesz Nauk UE Poz. 2012:247:130-136.

8. Jarosławska-Kolman K. System Państwowego Ratownictwa Medycznego w Polsce. Zesz Nauk SGSP. 2016;60(4):169-170.

9. Grzymała-Kazłowski M. Obszar SOR i koncepcje działania gorącej platformy. Ogolnopol Przegl Med. 2016;1-2:57-62.

10. Dobre praktyki postępowania w szpitalnych oddziałach ratunkowych i w izbach przyjęć. Ministerstwo Zdrowia. Warszawa; 04.04.2017 r.

11. http://medicalonline.pl/a926-organizacja-szpitalnego-oddzialu-ratunkowego.html.

12. Nowakowski J, Timler D. Struktura organizacyjna i wyposażenie szpitalnych oddziałów ratunkowych. Ogolnol Przegl Med. 2016;1-2:23-26.

13. Rozporządzenie Ministra Zdrowia z dnia 27 czerwca 2019 r. w sprawie szpitalnego oddziału ratunkowego. Dz.U. 2019; poz. 1213.

14. Regulamin Organizacyjny Samodzielnego Publicznego Zakładu Opieki Zdrowotnej Wojewódzkiego Szpitala Specjalistycznego nr 3 w Rybniku. Rybnik; 20 grudnia 2017 r.

15. Statut Samodzielnego Publicznego Zakładu Opieki Zdrowotnej Wojewódzkiego Szpitala Specjalistycznego nr 3 w Rybniku. Załącznik do uchwały nr V/12/29/2015 Sejmiku Województwa Śląskiego. Katowice; 21 września $2015 \mathrm{r}$.

16. Statystyka z wykorzystania łóżek rzeczywistych w SP ZOZ WSS nr 3 w Rybniku. Dział Statystyki Medycznej i Kontraktowania. Rybnik; 12. 02. 2018 r.

ORCID AND CONTRIBUTIONSHIP *

Piotr Kuczera - 0000-0003-4574-1729 A, B, , , D,E,F

\section{CONFLICT OF INTEREST}

Author declares no conflict of interest.

\section{ADDRESS FOR CORRESPONDENCE}

Piotr Kuczera

Szpitalny Oddział Ratunkowy,

Wojewódzki Szpital Specjalistyczny nr 3 w Rybniku, ul. Energetyków 46, 44-200 Rybnik, Poland e-mail: pkuczera@o2.pl

RECEIVED

03.03.2020
ACCEPTED

21.06.2020

* Contribution: A - Work concept and design, B - Data collection and analysis, C - Responsibility for statistical analysis, D-Writing the article, E-Critical review, F- Final approval. 


\title{
SUDDEN CARDIAC ARREST IN PATIENTS OVER 60 YEARS OF AGE IN THE OPERATION AREA OF EMERGENCY MEDICAL SERVICE IN SIEDLCE IN 2013-2017
}

\author{
Agnieszka Hawrylewicz-Łuka', Robert Gałązkowski², Daniel Celiński',2, Krzysztof Mitura', \\ Leszek Szpakowski', Sławomir Pilip', Paweł Świniarskii, Klaudiusz Nadolny ${ }^{4}$ \\ 1 "RM MEDITRANS" EMERGENCY AND SANITARY TRANSPORT STATION IN SIEDLCE, SIEDLCE, POLAND \\ 2 DEPARTMENT OF EMERGENCY MEDICAL SERVICE, MEDICAL UNIVERSITY OF WARSAW, WARSAW, POLAND \\ 3 COLLEGE OF REHABILITATION, WARSAW, POLAND \\ 4 DEPARTMENT OF EMERGENCY MEDICAL SERVICE, STRATEGIC PLANNING UNIVERSITY OF DABROWA GORNICZA, DABROWA \\ GORNICZA, POLAND
}

\section{Abstract}

Introduction: Sudden cardiac arrest is an integral part of the end of every human life.

The aim: To analyze and determine the characteristics of the geriatric patients with sudden cardiac arrest.

Material and methods: This was a retrospective study covering the operation area of the Emergency Medical Service in Siedlce. Time range: from January 1, 2013 to December 31, 2017. The Chi2 test was used to assess the significant differences between the analyzed qualitative variables. The level of significance was 0.05 .

Results: Out of 182,584 emergency medical records collected over 5 years, 5682 cases were manually selected as interventions for a patient with sudden cardiac arrest. This represented $3.11 \%$ of all medical services provided, from which a group of $n=3840$ patients over 60 years of age was selected. The patient had usually between 75 and 90 years of age. The mean age was 75.55 years. The mean arrival time to such a patient was $10.28 \mathrm{~min}$. The most common ECG rhythm was asystole, followed by return of spontaneous circulation (ROSC) in $12.71 \%$ of cases ( $n=67$ ). No mechanical chest compression equipment was used. Most often adrenaline and fluid therapy were administered after obtaining intravenous access. Mostly, the witness of the event did not undertake rescue activities. The mean resuscitation time was 48.11 min in the case of ROSC, and 36.98 minutes, if there was no ROSC.

Conclusions: In the studied group of patients over 60 years, the chances of ROSC clearly decreased with age.

\section{INTRODUCTION}

The issue of sudden cardiac arrest has been raised many times, and many researchers have attempted to define this problem, determine its causes, mechanisms and rescue procedures. The issue has been perfectly described, but current medical knowledge on this subject cannot fully predict all circumstances related to sudden cardiac arrest. Scientists are not able to clearly predict the time of its occurrence, baseline mechanisms and no sufficiently successful treatment is available.

The old age is a natural period of life for every organism. It occurs naturally in nature and appears as a result of exceeding a certain age by the human body. The aging process has been described in literature in many ways: some sources recognize the beginning of old age at the age of over 60 , while others point to the later time and define it as the age of 65 or over. The concept of old age is therefore relative, since metrical age is not always consistent with biological age.
For the purposes of the following study, however, the criterion of the World Health Organization (WHO) was adopted and the age of 60 was indicated as the beginning of old age.

In the operational area 14-04, covering the scope of the Emergency Medical Service (EMS) in Siedlce, there are 25 EMS teams, including 7 specialist EMS teams (which consist of three people: a system doctor, a driver or a driver-paramedic and a paramedic or a nurse of the system), 18 basic EMS teams (which consist of two or three people: a team leader - a paramedic and a driver-paramedic, and with a three-member staff, an additional paramedic or system nurse is present) and one air EMS team stationed in Sokołów Podlaski.

\section{THE AIM}

The aim of the study was to analyze and determine the characteristics of the patients over 60 years of age with sudden cardiac arrest. 


\section{MATERIAL AND METHODS}

The study was conducted on a population of patients in the area of operation of the Independent Public Health Care Center "RM MEDITRANS" EMS and Sanitary Transport Station in Siedlce in the years 2013-2017.

Medical rescue activity cards and dispatch order cards from the area of activity 14-04 were analyzed. Obtained data from the medical documentation of basic and specialist EMS teams were collected and stored in a database created in Microsoft Excel software (MS Office 2016 for Windows 10). The obtained results were statistically analyzed using the STATISTICA 13 program (StatSoft, Kraków, Poland).

In the description of quantitative data, the mean (M), standard deviation (SD), median (Me), minimum (Min), maximum (Max), bottom quartile (Q1) and upper quartile $(\mathrm{Q} 3)$ were used. However, qualitative data were presented as numbers (n) and percentage (\%).

The normality of the distribution of variables was verified using the Shapiro-Wilk test. The non-parametric U Mann-Whitney test was used to investigate the differences between the two groups. The $\mathrm{Chi}^{2}$ test was used to assess the significant differences between the analyzed qualitative variables. The study adopted the significance level of 0.05 , which means that the probability of making a mistake and rejecting the null hypothesis does not exceed $5 \%$.

\section{RESULTS}

The area of operation of the EMS in Siedlce covers the eastern part of Mazovia and extends over an area of $7,350 \mathrm{~km}^{2}$, which is inhabited by about 547,000 people. In the years 2013-2017, EMS teams working in EMS in Siedlce carried out 182,584 interventions. Of all medical services provided, 5,682 were interventions for patients with sudden cardiac arrest. This represented $3.11 \%$ of all medical services provided in the given period in a given area. The study group was selected in accordance with age criteria for the elderly according to World Health Organization (WHO) and these were patients over 60 years of age. They constituted a group of 3,840 people.

The patient was mostly of middle-old age, i.e. between 75 and 90 years of age. The mean age was 75.55 years (Table 1 ).

The mean arrival time to such a patient was $10.28 \mathrm{~min}$.

Mostly, asystole was the baseline rhythm observed in the electrocardiogram (ECG). Authors observed the regularity that the chances of the return of spontaneous circulation (ROSC) clearly decreased with age. In addition, in case of asystole in the young-old age, i.e. in a patient between the ages of 60 and 75 years old, the chances of ROSC did not exceed $15 \%$. (Fig. 1)

Table 1. Population of the operating area 14-04 as at December 31, 2018.

\begin{tabular}{|c|c|c|c|c|c|c|c|c|}
\hline District & garwoliński & łosicki & miński & siedlecki & Siedlce (city) & sokołowski & węgrowski & $\begin{array}{l}\text { Jadów and } \\
\text { Strachówka }\end{array}$ \\
\hline Population & 108993 & 31023 & 117936 & 81352 & 77872 & 54217 & 66174 & 10299 \\
\hline
\end{tabular}

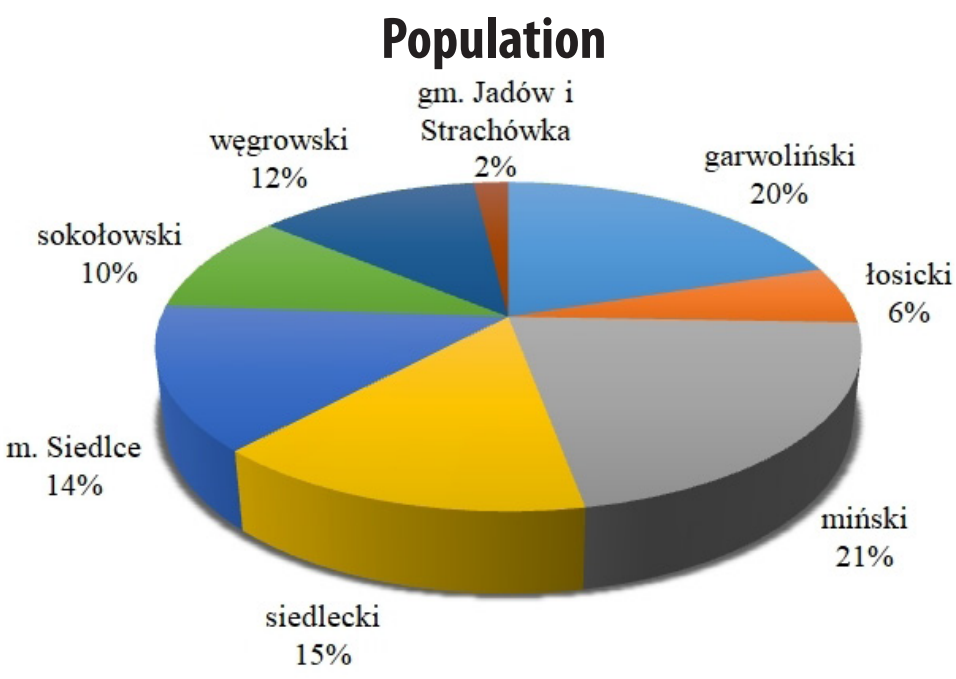

arwoliński

siedlecki

wegrowski

łosicki

m. Siedlce

घm. Jadów i Strachówka

miński

sokołowski

Fig. 1. Population of the operating area 14-04 as at December 31, 2018. 
Table 2. Analysis of the relationship between ROSC and sex, age, location of the call, mean age, mean arrival time, and mean time of resuscitation in patients with sudden cardiac arrest over the age of 60 on the area of operation of the EMS in Siedlce.

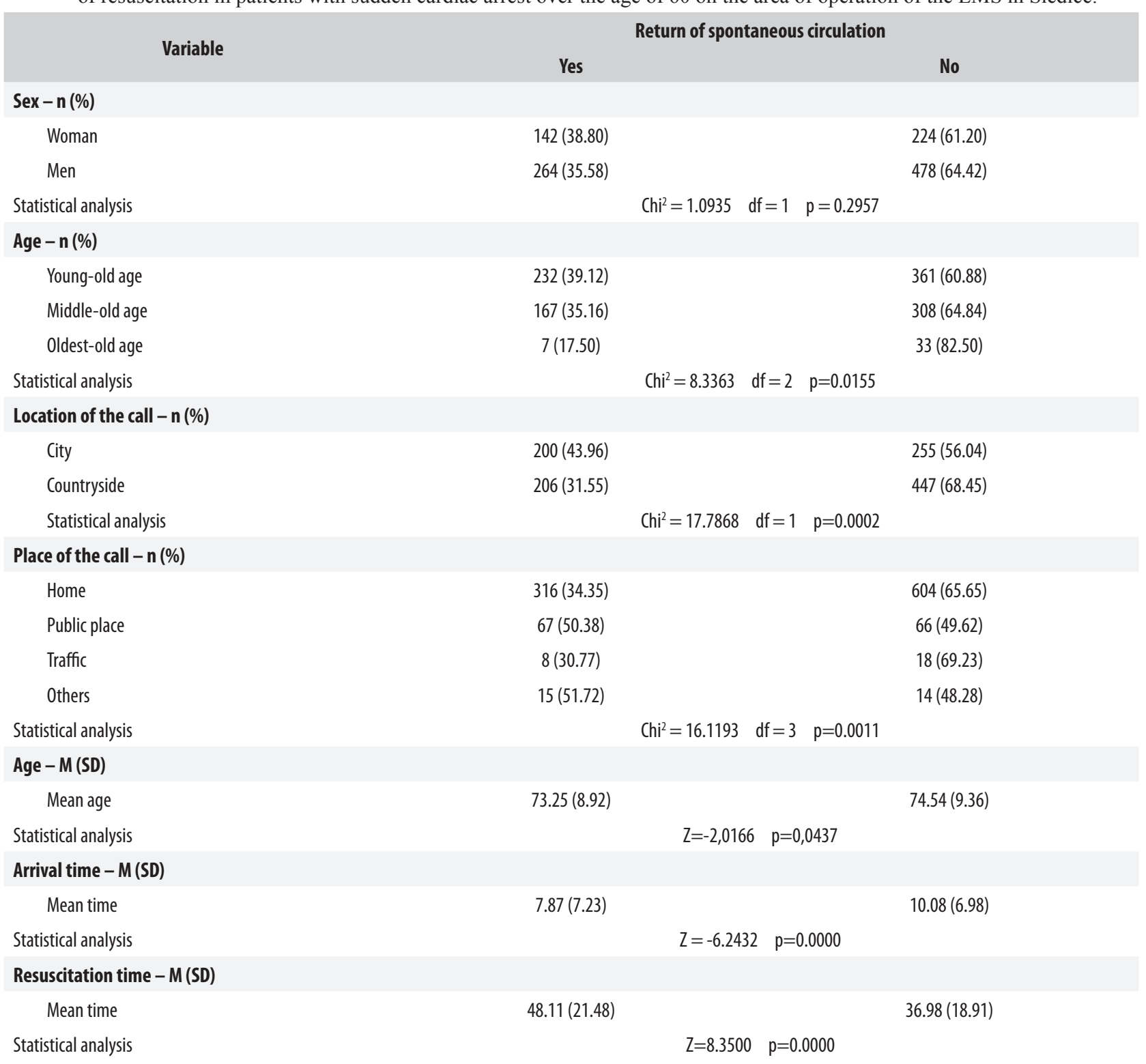

Mostly, the witness of the event did not undertake rescue activities. If the witness of the event did not undertake the basic rescue activities according to BLS (Basic Life Support), then ROSC did not return in $61.70 \%(n=385)$ of cases. However, if BLS was performed by the witness of the event, then ROSC was obtained in $41.13 \%(n=167)$ of cases (Table 3$)$. However, this indicated that frequently witnesses of the event did not undertake BLS activities.

No mechanical chest compression equipment was used. Most often adrenaline and fluid therapy were administered after obtaining intravenous access.

More sudden cardiac arrests were observed in the countryside, but more ROSC cases were obtained in the city. This is certainly due to the characteristics of the area of the operation of the EMS in Siedlce, where the majority of the population lives in rural areas. In the presented study, the city and the countryside were indicated, classified and described in accordance with the territorial division of the country.

The mean resuscitation time was $48.11 \mathrm{~min}$ in the case of ROSC, and $36.98 \mathrm{~min}$ if no ROSC was observed (Table 2).

When analyzing the ROSC rate in the context of the reason for the call one observed that most often ROSC was obtained when the reason for the call was the password: chest pain $(53.85 \%)$, fainting $(48.31 \%)$ and shortness of breath $(46.51 \%)$. The 
Table 3. Analysis of the relationship between ROSC and the type of syndromes, the reason for summoning, BLS performed by witnesses, the initial ECG rhythm in patients with sudden cardiac arrest.

\begin{tabular}{|c|c|c|c|}
\hline \multirow{2}{*}{ Variable } & \multicolumn{3}{|c|}{ Return of spontaneous circulation } \\
\hline & Yes & & No \\
\hline \multicolumn{4}{|l|}{ EMS team type - n (\%) } \\
\hline Basic & $162(39.80)$ & & $245(60.20)$ \\
\hline Specialist & $244(34.81)$ & & $457(65.19)$ \\
\hline Statistical analysis & \multicolumn{3}{|c|}{$\mathrm{Chi}^{2}=4.7685 \quad \mathrm{df}=1 \quad \mathrm{p}=0.0461$} \\
\hline \multicolumn{4}{|l|}{ Reason for call - $n(\%)$} \\
\hline Unconscious & $146(36.59)$ & & $253(63.41)$ \\
\hline Sudden cardiac arrest & $38(32.48)$ & & 79 (67.52) \\
\hline Not breathing & $23(28.05)$ & & $59(71.95)$ \\
\hline Fainting & $57(48.31)$ & & $61(51.69)$ \\
\hline Dyspnea & $40(46.51)$ & & $46(53.49)$ \\
\hline Chest pain & $21(53.85)$ & & $18(46.15)$ \\
\hline No contact & $10(25.64)$ & & $29(74.36)$ \\
\hline Probably dead & $1(2.70)$ & & $39(97.30)$ \\
\hline Accident & $4(15.38)$ & & $22(84.62)$ \\
\hline Statistical analysis & & $p=0.0000$ & \\
\hline \multicolumn{4}{|l|}{ BLS by a witness - $\mathrm{n}(\%)$} \\
\hline Yes & $167(41.13)$ & & $317(59.87)$ \\
\hline No & $239(38.30)$ & & $385(61.70)$ \\
\hline Statistical analysis & & $p=0.0100$ & \\
\hline \multicolumn{4}{|l|}{ Baseline rhythm - $\mathbf{n}(\%)$} \\
\hline Asystole & $67(12.71)$ & & $460(87.29)$ \\
\hline PEA & $115(50.44)$ & & $113(49.56)$ \\
\hline VF/VT & $146(55.09)$ & & $119(44.91)$ \\
\hline Sinus rhythm & $78(88.64)$ & & $10(11.36)$ \\
\hline Statistical analysis & & $p=0.0461$ & \\
\hline
\end{tabular}

lowest ROSC rate values were obtained in case of calls such as: probably dead $(2.70 \%)$ and accident (15.38\%) (Table 3).

In summary, out-of-hospital cardiac arrest is a serious challenge for health care units in Poland and worldwide. The survival chain already started by the event witness can significantly contribute to extending lives of patients over 60 years of age. EMS equipped with appropriate medical equipment and properly trained medical staff can basically improve the quality of emergency medical activities and extend lives of seniors.

\section{DISCUSSION}

The presented publication adopted the age criterion of the World Health Organization (WHO):

- young-old age (old age) is between 60 and 74 years old,

- middle-old age (late old age) - between 75 and 89,

- oldest-old age (longevity) - from the age of 90 [1].
The operation area 14-04 includes the following districts: garwolinski, losicki, miński (without the city of Sulejowek and the Halinow commune), siedlecki (rural and municipal), sokolowski, wegrowski, as well as the Jadow commune and Strachowka commune in the Wolomin district, with a total area of $7350 \mathrm{~km}^{2}$. It is inhabited by about 547000 people [2].

In the years 2013-2017, the EMS in Siedlce performed 182584 interventions in the area of its operation. In 2013 there were 33449 interventions, in 2014 - 35050 interventions, in 2015 - 36690 interventions, in 2016 - 37700 interventions, and in 2017 - 39695 interventions.

The study showed that among all medical services provided, 5682 were interventions for a patient with sudden cardiac arrest. This represented $3.11 \%$ of all medical services provided in the given period in a given area. From the study group of 5,682 people with sudden cardiac arrest, a group of 3,840 people 
Table 4. Analysis of the relationship between patient age, baseline rhythm, and ROSC and lack of ROSC in patients with sudden cardiac arrest over the age of 60 in the operation area of the EMS in Siedlce.

\begin{tabular}{|c|c|c|c|}
\hline Baseline rhythm & Age & ROSC & No ROSC \\
\hline \multirow[t]{3}{*}{ Asystole } & $\begin{array}{l}\text { Young-old age } \\
\text { n(\%) }\end{array}$ & $39(14.29)$ & $234(85.71)$ \\
\hline & $\begin{array}{l}\text { Middle-old age } \\
\mathbf{n}(\%)\end{array}$ & $26(11.50)$ & $200(88.50)$ \\
\hline & $\begin{array}{l}\text { Oldest-old age } \\
\mathrm{n}(\%)\end{array}$ & $2(7.14)$ & $26(92.86)$ \\
\hline \multirow[t]{3}{*}{ PEA } & $\begin{array}{l}\text { Young-old age } \\
\mathrm{n}(\%)\end{array}$ & $54(54.00)$ & $46(46.00)$ \\
\hline & $\begin{array}{l}\text { Middle-old age } \\
\text { n (\%) }\end{array}$ & $59(49.58)$ & $60(50.42)$ \\
\hline & $\begin{array}{l}\text { Oldest-old age } \\
\mathrm{n}(\%)\end{array}$ & $2(22.22)$ & $7(77.78)$ \\
\hline \multirow[t]{3}{*}{ VF/VT } & $\begin{array}{l}\text { Young-old age } \\
\text { n(\%) }\end{array}$ & $92(55.76)$ & $73(44.24)$ \\
\hline & $\begin{array}{l}\text { Middle-old age } \\
\mathrm{n}(\%)\end{array}$ & $53(53.54)$ & $46(46.46)$ \\
\hline & $\begin{array}{l}\text { Oldest-old age } \\
\mathrm{n}(\%)\end{array}$ & $1(100.00)$ & $0(0.00)$ \\
\hline \multirow[t]{3}{*}{ Sinus rhythm } & $\begin{array}{l}\text { Young-old age } \\
\text { n(\%) }\end{array}$ & $47(85.45)$ & $8(14.55)$ \\
\hline & $\begin{array}{l}\text { Middle-old age } \\
\text { n (\%) }\end{array}$ & $29(93.55)$ & $2(6.45)$ \\
\hline & $\begin{array}{l}\text { Oldest-old age } \\
\text { n (\%) }\end{array}$ & $2(100.00)$ & $0(0.00)$ \\
\hline
\end{tabular}

was selected according to age criteria for the elderly according to WHO.

The characteristics of the study group showed that mostly the patient was a man living in the countryside, and the intervention was carried out at the patient's home by the EMS team. The patient was mostly of middle-old age, i.e. between 75 and 90 years of age. The mean age was 75.55 years. The mean arrival time to such a patient was $10.28 \mathrm{~min}$. The baseline ECG rhythm was asystole. The witness of the event did not undertake rescue activities. No mechanical chest compression equipment was used. Most often adrenaline and fluid therapy were administered after iv access was provided.

As indicated in the characteristics of the study group, more often men over 60 years of age $(n=2506)$ suffered from sudden cardiac arrest than women $(n=$ 1334 ). Men constituted $65.26 \%$ of the study group of patients. Spontaneous circulation was restored in $38.80 \%$ of women ( $\mathrm{n}=142)$, and in $35.58 \%$ of women $(n=264)$ (Table 1). Similar data can be found in three publications on similar topics [3-5]. In the study of Nadolny, Święty, and Ślęzak from 2018, the percentage of out-of-hospital sudden cardiac arrest in men was $63.68 \%$, and in women it was $34.5 \%$ [3]. In the Swedish study on out-of-hospital sudden cardiac arrests in
1992 - 2011 published in 2015, Strömsöe et al. [4] also determined the percentage of women with sudden cardiac arrest at around $30 \%$. The study included all outof-hospital sudden cardiac arrest cases $(n=59$ 926) reported to the Swedish Sudden Cardiac Arrest Registry.

However, despite the fact that in the Australian study Brey et al. [5] the focus was on adults with sudden cardiac arrest in the years 2003-2010 and they were between 18 and 44 years of age, there was a very important issue found out that female survival was higher than that of men in pre-hospital sudden cardiac arrest. Their research also showed that with age, the chances of ROSC were decreasing.

In our study a statistically significant association between age and ROSC was revealed $(p=0.0155)$. Most ROSC cases were observed in the group of young-old age people, i.e. from 60 to 75 years of age, which constituted $39.12 \%(n=232)$. The lowest survival rate was recorded in the group of people of oldest-old age, i.e. over 90 years old and it was 7 people, which constituted $17.50 \%$ of the analyzed cases. This is probably reflected in the natural process of aging and dying. In case of sudden cardiac arrest mortality increases and survival decreases with age.

Analyzing the correlation between the place of call and ROSC, statistically significant relationship 
was found $(\mathrm{p}=0.0002)$. In the city the ROSC rate was $43.96 \%$, and in the countryside $-31.55 \%$. The characteristics of the studied group also showed that more sudden cardiac arrest cases took place in the countryside ( $\mathrm{n}=2372,61.77 \%$ ) than in the city $(38.23 \%, \mathrm{n}=1468)$. Despite the fact that more sudden cardiac arrest cases were in the countryside, there were more ROSC cases in the city. This may be due to several factors such as arrival time, BLS, event witness, multiple comorbidities before sudden cardiac arrest as well as the awareness and access to health care facilities. Other authors also noted it in their research: Cebula, Osadnik, Wysocki [6]. In their study, there were $736(30.48 \%)$ cases of ROSC, including $374(32.13 \%)$ cases in urban areas and $362(28.94 \%)$ cases in countryside areas. The difference in the frequency of ROSC between the study groups was not statistically significant $(p=0.088)$. Compared to urban areas, in countryside areas significantly more often witnesses of the incident resuscitated and received instructions from medical dispatchers [6].

The location of the call also proved to have statistical significance at the level of $p=0.0011$ in relation to obtaining ROSC. Most cases happened at home (316 cases). The return of spontaneous circulation was obtained in $34.35 \%$ of cases. Most ROSC cases were observed in a public place $(50.38 \%)$. The least frequently ROSC cases were noted in the street and road traffic $(30.77 \%, \mathrm{n}=8)$ (Table 2$)$.

The study showed that the mean age of a patient with ROSC was 73.25 years, and with no ROSC 74.54 years. With increasing age, the ROSC rate decreased. The above results were statistically significant $(\mathrm{p}=0.0437)$.

The mean time to reach the patient was $7.87 \mathrm{~min}$ in the case of ROSC, and $10.08 \mathrm{~min}$ if there was no ROSC. Arrival time statistically significantly correlated with ROSC $(p=0.0000)$. In the study of Onions et al. [6], where the registry covered data from January 2013 to May 2014, and the study covered an area of $23706 \mathrm{~km} 2$, in different parts of the country, comparing early outpatient resuscitation effects in selected urban and countryside areas in Poland, median time of the arrival of the ambulance at the scene was much shorter in urban areas compared to countryside areas (median time: 6 minutes and 12 minutes, respectively) [6]. In the study of Gach D. et al. [7] conducted over a 12-month period in Bielsko-Biala from $01 / 01 / 2013$ to $31 / 12 / 2013$, the median time from receipt of the call by EMS teams to the arrival of the team was 9 (7-11) $\min$ [7].

The mean resuscitation time was $48.11 \mathrm{~min}$ in case of ROSC, and 36.98 minutes if no ROSC was observed. The resuscitation time significantly correlated with ROSC $(p=0.0000)$.

The presented study also analyzed the relationship between ROSC and the type of teams, the reason for calls, BLS witnesses, the initial ECG rhythm in patients with sudden cardiac arrest over the age of 60 in the operation area of the EMS in Siedlce (Table 2). Specialist EMS teams were more often dispatched to sudden cardiac arrest, however, basic EMS teams obtained a higher percentage of ROSC than specialist EMS teams (39.80\% vs. 34.81\%). The difference was statistically significant $(\mathrm{p}=0.0461)$. It is also a result of the fact that paramedics cannot declare death. This issue has not yet been regulated. The doctor may declare death and issue a death card, while the paramedic does not have such rights. He can only withdraw from medical emergency activities.

In the analyzed research material, the most common reasons for the summons were: unconscious, sudden cardiac arrest, not breathing, fainting, shortness of breath, chest pain, no contact, probably dead, accident. Analysis of correlation between ROSC and the reason for the call indicated that most often ROSC was obtained when the reason for the call was the term: chest pain $(53.85 \%)$, fainting $(48.31 \%)$ and shortness of breath (46.51\%). The lowest ROSC rate values were obtained in case of reasons for summons such as: probably dead (2.70\%) and accident $(15.38 \%)$. The relationship was statistically significant $(\mathrm{p}=0.0000)($ Table 3$)$.

The relationship between BLS occurrence and the ROSC was also investigated. If the witness of the event did not undertake BLS rescue activities, then ROSC did not return in $61.70 \%(n=385)$ of investigated cases. If, on the other hand, BLS was performed by an event witness, then ROSC was obtained in $41.13 \%(n=167)$ of cases. The results were statistically significant $(p=0.0100)$ (Table 3$)$. In the study of Nadolny et al. [8], conducted in the population covered by the activity of the Voivodship EMS in Katowice in 2016, it was found that first aid was provided by witnesses of the event, most often chest compressions, in $59.88 \%$ of cases. A higher ROSC rate was found in those patients in whom BLS was undertaken by the witness of the event, with instructions for performing first aid over the phone by a medical dispatcher, and when the EMS team was in the $\mathrm{K}-1$ code. Then ROSC was recorded in $33.4 \%$ of cases [8].

The analysis of the baseline rhythm in the ECG in relation to ROSC indicated that the most common rhythm followed by ROSC was a sinus rhythm, i.e. a situation in which in the presence of the EMS team sud- 
den cardiac arrest appeared and initiated medical activities enabled ROSC in $88.64 \%$ of cases (Table 2). At the initial VF / VT rhythm, 55.09\% of the cases ended up with ROSC, and at PEA - 50.44\%. The worst prognosis was associated with asystole, with only $12.71 \%$ of cases with ROSC. It is worth noting that most sudden cardiac arrest cases, however, were in asystole, which turned out to be the least promising rhythm in the study, with no ROSC in $87.29 \%$ of cases. In the study Do et al. [9] published as a report of the Ministry of Health of Australia from 2012, it was found that in the studied patients over 65 years of age, $61 \%$ of them died on the day of sudden cardiac arrest [9].

The correlation between a baseline ECG rhythm and ROSC turned out to be statistically significant $(p=0.0461)$. For the baseline rhythms in the ECG, authors could see the regularity that with age the chances of ROSC clearly decreased (Table 4). For PEA, these values were balanced for the young-old age and middle-old age, but already in oldest-old age, i.e. over 90 years, the chances of ROSC were significantly lower (22.22\%) (Table 4).

For VF / VT, also ROSC values were clearly higher $[10,11]$. In an Irish study of Kiran et al. 2013 [10], conducted for one year in County Cork, it was found that VF / VT rhythms occurred in 36 cases (16\% of the study group). Resuscitation was undertaken in 176 cases $(77.5 \%)$, in which ROSC was observed in 27 $(15 \%)$ cases. This study also clearly showed that the VF / VT ECG rhythms were more likely to achieve ROSC than the other rhythms found in sudden cardiac arrest. An overall survival rate of $16.7 \%$ in case of rhythms to defibrillation indicated that they were associated with a greater chance of ROSC than the overall survival rate in this study, which was $7.4 \%$ [10]. In the Netherlands, in 2016, comparative studies were carried out for two periods: 1995-1997 and 2006-2012, for people with out-of-hospital cardiac arrest. The analysis was made by Hulleman et al. [11], in which it was indicated that despite a $15 \%$ decrease in VF between periods, the VF percentage remained high in 2006-2012 and amounted to 64\% [11].

ROSC in the oldest-old age for the ECG -VF / VT rhythm turned out to be at the level of $100 \%$, but it was only 1 case, hence such a percentage picture (Table 1).

At sinus rhythm, as a baseline rhythm, authors could see more frequent recovery of spontaneous circulation in the young-old age in $85.45 \%$ of cases, and in the middle-old age between 75 and 90 years old in $93.55 \%$ of cases. Also, in oldest-old age, the study showed $100 \%$ ROSC for a patient with sinus rhythm as the baseline rhythm, but these were only 2 cases (Table 4).
For the baseline rhythms in the ECG, authors could see the regularity that with age the chances of ROSC clearly decreased. In addition, with asystole already in the young-old age, i.e. in a patient between the ages of 60 and 75, the chances of ROSC did not exceed $15 \%$ (Table 4 ).

In terms of ROSC it did not matter whether the place of call was a city or countryside, home, public place, traffic and other places, in cases of medical emergency activities such as oxygen therapy, mechanical ventilation, intubation, mechanical chest compression, or iv access. It was also irrelevant for ROSC whether the basic EMS team or the specialist EMS team intervened in the studied cases. The analyzed data indicated similar values, i.e. one could conclude that both EMS teams performed equal medical emergency services dedicated to patients with sudden cardiac arrest.

There is a clear increase in the use of mechanical chest compression devices. This is related to the availability of these devices, also in basic EMS teams. The increase in the availability of devices for mechanical compression of the chest in the EMS in Siedlce was from about $2 \%$ in 2013 to $35 \%$ in 2015 . These values steadily increased along with the purchase of new devices and their distribution to EMS teams.

The results of EuReCa ONE analyzing out-ofhospital cardiac arrests in 27 countries in Europe emphasize that OHCA is still a serious public health problem that contributes to a significant number of deaths in Europe [12]. The study showed data on 10682 confirmed OHCA from 248 regions in 27 countries, covering an estimated population of 174 million. Data from 2014 was collected and published in 2016 as a joint work of many global researchers on the subject of sudden cardiac arrest. In 7,146 cases, $66 \%$ of cardiopulmonary resuscitation was started by a witness of the event or medical emergency operations were undertaken by the EMS teams. In $25 \%$ of cases, ROSC was obtained before arrival to the hospital [12].

\section{CONCLUSIONS}

The presented study showed an analysis of cases of sudden cardiac arrest in patients over 60 years of age in the area of the EMS in Siedlce in 2013-2017. It indicated that:

1. Sudden cardiac arrest occurred more often in men than women.

2. In the examined group of patients over 60 years of age, the chances of ROSC clearly decreased with age.

3. There were more cardiac arrests in the countryside, but there were more ROSC in the city. 
4. The time to reach a patient with sudden cardiac arrest was crucial for ROSC.

5. Extending the resuscitation time of a patient over 60 years of age raised the chances of ROSC.

6. Failure of the witness to take BLS reduced the chances of obtaining ROSC.
7. The most common rhythm noted on the ECG was asystole and this rhythm was the least promising for the patient. ROSC was obtained significantly more rarely.

8. The most promising ECG rhythm for achieving ROSC was VF / VT.

\section{REFERENCES}

1. Nowicka A. Starość jako faza życia człowieka. In: Nowicka A. Wybrane problemy osób starszych. Oficyna Wydawnicza „Impuls” Kraków 2008, pp. 17-25.

2. Rocznik Demograficzny 2019. Warszawa: GUS; 2019, pp. 85, 94, 111, 113, 129.

3. Nadolny K, Ładny J, Ślęzak D. Wpływ udzielanych czynności medycznych, a skuteczność resuscytacji w pozaszpitalnym nagłym zatrzymaniu krążenia u osób dorosłych. Post N Med. 2018:31;6: 308-313.

4. Strömsöe A, Svensson L, Axelsson A et al. Improved outcome in Sweden after out-of-hospital cardiac arrest and possible association with improvements in every link in the chain of survival. Eur Heart J. 2015:36:863-871.

5. Bray J, Stub D, Bernard S. Exploring gender differences and the „oestrogen effect” in an Australian outof-hospital cardiac arrest population. Resuscitation. 2013:84;957-963.

6. Cebula GM, Osadnik S, Wysocki M et al. Comparison of the early effects of out-of- hospital resuscitation in selected urban and rural areas in Poland. A preliminary report from the Polish Cardiac Arrest Registry by the Polish Resuscitation Council. Pol Heart J. 2016;74:143-148.

7. Gach D, Nowak J, Krzych L: Epidemiology of out-of-hospital cardiac arrest in the Bielsko-Biala district: a 12-month analysis. Kardiol Pol. 2016;74(10):1180-1187.

8. Nadolny K, Gotlib J, Panczyk M et al. The role oft he witness oft he incident and the role oft he emergency medical dispatcher in out-of-hospital sudden cardiac arrest. Post N Med. 2018;31(1):6-11.

9. Do A, Cretikos M, Muscatello D. Epidemiology of out-of-hospital cardiac arrest, NSW. Time, place and person. Centre for Epidemiology and Evidence, In: NSW Ministry of Health, Sydney 2013, p. 1-14.

10. Henry K, Murphy A, Willis D et al. Out-of-hospital cardiac arrest in Cork, Ireland. Emerg Med J. 2013;30:496-500.

11. Hulleman M, Zijlstra JA, Beesems SG et al. Causes for the declining proportion of ventricular fibrillation in out-of-hospital cardiac arrest. Resuscitation. 2015;96: 23-29.

12. Gräsner JT, Lefering R, Koster RW. EuReCa ONE-27 Nations, ONE Europe, ONE Registry: A prospective one month analysis of out-of-hospital cardiac arrest outcomes in 27 countries in Europe. Resuscitation. 2016;105:188-195.

\section{ORCID AND CONTRIBUTIONSHIP *}

Agnieszka Hawrylewicz-Łuka

$$
\text { - 0000-0003-0725-2916 A,B,,,,D,E,F, }
$$

Robert Gałązkowski - 0000-0002-7205-2219 B,C,E,F

Daniel Celiński - 0000-0001-8746-3814 B.,E,E

Krzysztof Mitura - B,E

Leszek Szpakowski - $\mathbf{E , F}$

Sławomir Pilip - 0000-0003-2208-4965 E,F

Klaudiusz Nadolny - 0000-0003-0355-241X E,F

Paweł Świniarski - 0000-0003-0740-4596 B,E

\section{ADDRESS FOR CORRESPONDENCE}

Agnieszka Hawrylewicz-Łuka

SP ZOZ „RM MEDITRANS”

B-pa I. ul. Świrskiego 38, 08-110 Siedlce, Poland

tel.: 660-400-400

e-mail: agahawrylewiczluka@wp.pl

\section{CONFLICT OF INTEREST}

Authors declare no conflict of interest.
RECEIVED

19.03.2020
ACCEPTED

26.06.2020

*Contribution: A-Work concept and design, B-Data collection and analysis, C - Responsibility for statistical analysis, D-Writing the article, E-Critical review, F-Final approval. 


\title{
THE ASSESSMENT OF WORK BURNOUT AND LIFE SATISFACTION AMONG NURSES WITH THE USE OF COPENHAGEN BURNOUT INVENTORY
}

\author{
Bianka Misiak', Jolanta Lewko'2, Regina Sierżantowicz ${ }^{3}$, Karolina Lewko ${ }^{4}$, Andrzej Guzowski ${ }^{5}$, \\ Hady Razak Hady ${ }^{6}$, Jerzy Robert Ładny ${ }^{7}$ \\ 1 MEDICAL UNIVERSITY OF BIALYSTOK, CHILDREN'S CLINICAL HOSPITAL, BIALYSTOK, POLAND \\ 2 DEPARTMENT OF PRIMARY HEALTH CARE, MEDICAL UNIVERSITY OF BIALYSTOK, BIALYSTOK, POLAND \\ 3 DEPARTMENT OF SURGICAL NURSING, MEDICAL UNIVERSITY OF BIALYSTOK, BIALYSTOK, POLAND \\ 4 INTERNATIONAL MEDICAL STUDENTS ASSOCIATION-POLAND (IFMSA-POLAND), MEDICAL UNIVERSITY OF BIALYSTOK, \\ BIALYSTOK, POLAND \\ 5 DEPARTMENT OF INTEGRATED MEDICAL CARE, MEDICAL UNIVERSITY OF BIALYSTOK, BIALYSTOK, POLAND \\ $61^{\text {ST }}$ CLINICAL DEPARTMENT OF GENERAL AND ENDOCRINE SURGERY, MEDICAL UNIVERSITY OF BIALYSTOK, BIALYSTOK, \\ POLAND \\ 7 DEPARTMENT EMERGENCY MEDICINE AND DISASTER, MEDICAL UNIVERSITY OF BIALYSTOK, BIALYSTOK, POLAND
}

\section{Abstract}

Introduction: The factors associated with work and the structure of a given organisation can influence on appearing the burnout of its employees. It does most often affect people who do not have an ability to manage stress as well as those who are not provided enough with social support.

The aim: The main purpose of the study was to assess the burnout symptoms and satisfaction of personal life of nurse staff over the age of 40 . The influence of demographic-occupational factors was evaluated in connection with the occurrence of work burnout.

Material and methods: The research included a group of 523 randomly chosen workforce nurses over 40 years old, CBI - Copenhagen Burnout Inventory was used in the research, the assessment of life satisfaction was conducted with the use of SWLS - The Satisfaction with Life Scale.

Results: The nurses in a worse material situation feel higher work burnout in almost all researched category. Those who do not achieve satisfaction from work have definitely much higher level of work burnout than those nurses who declare high satisfaction level from their work. The higher work burnout, the less life satisfaction.

Conclusions: The level of burnout in the surveyed group can be considered as a moderate one.

\section{Key words}

nurses, burnout syndrome, life satisfaction

\section{INTRODUCTION}

The labour of medical staff in consideration of a number of factors associated with both sick, often dying man as well as because of overload of work and shift night, the risk of making mistakes due to time pressure and the need of constant readiness, underequipped workstations, interpersonal conflicts make it really stressful. The occurrence of widespread aggression from colleagues as well as from patients can also be seen as really worrying. Long-term stress and common inability to change their situation can in consequence lead to burnout syndrome [1].

Personal engagement in people's problems, really intense and experienced on daily basis, causes high nervous tension. According to Maslach people who exploit their resources by giving all of themselves to other humans might in consequence lead to work burnout syndrome [2].

Not only factors related to labour and the structure of organization can influence on the appearance of burnout syndrome in workers. These ones also include: unclear roles especially in the field of responsibility and work goals; role conflict through receiving contradictory requirements; overwork in conditions of time pressure; lack of control and co-deciding; wrong internal communication, insufficient or lack of support from coworkers, superiors and other people; inadequate salary [3]. 


\section{THE AIM}

The aim of the study was to assess the burnout symptoms and satisfaction of life in nursing staff 40 years old or above. The influence of factors demographic and occupational on occurrence of burnout was examined.

\section{MATERIAL AND METHODS}

The research was performed from January to December 2015 in group of randomly chosen professionally active nurses above 40 years old in the Podlaskie voivodeship. The average age of surveyed nurses was $48.2 \pm 17.3$ years. The inclusion criteria were: (1) individuals aged 40 years old or above, and (2) individuals working as nurses. Nurses working in hospitals, various acute ward types, outpatient specialist care, primary health care, and others who agreed to participate were included in the study. People included in this study filled anonymous questionnaires. The prerequisite to participate in the study was a signed consent form declared agreement of respondents to partake in the study. A total of 560 questionnaires were distributed with the collaboration of the Chamber of Nurses and Midwives, and 523 envelopes were collected; they were the basis for the empirical analysis.

In the research there was used a questionnaire which was designed in order to obtain socio-demographic data of people involved in study. It consists questions about: age, gender, marital status, education, professional situation - having specialization, experience, number of workplaces, shift work, management position, working at a ward /clinic, reasons for choosing job, feeling of satisfaction and financial gratitude, family situation - marital status, having a partner, children, family structure, place of residence, number of co-residents, financial situation.

The symptoms of burnout were assessed using CBI - Copenhagen Burnout Inventory. CBI questionnaire is a tool from Denmark developed by Tage
S. Kristensen and a team of associates. It was used for the first time in November 1999. The questionnaire was used to measure a level of burnout in three aspects: personal, connected with work and related to contacts with patients. The guidance of questionnaire authors was followed, and definition of "Client" was changed into the term: patient [4]. The total result in every of three aspects of burnout forms from the average obtained from each part. The range of possible results is different for three subscales because they include different number of questions. This is a reason why a standardized scale of burnout in the range of 0-100 points was figured.

The assessment of life satisfaction was done using SWLS - The Satisfaction with Life Scale created by E. Diener, R. A. Emmons, R. J. Larsen, S. Griffin - Polish adoption: Z. Juszczyński.

The questionnaire is used to examine individual and group conduct of adults both healthy and sick. As a result of measurement overall satisfaction life rate is obtained. In American version, obtained measures based on it correlate averagely or highly with other measures of subjective well-being and chosen properties of personality. It correlates positively with sense of self-esteem but negatively with measures of neuroticism and emotionalism. In Polish version of the questionnaire similar statistical results were also attained [5].

The questionnaire of this survey contains 5 statements and the examined person must react to them by choosing one out of the seven possible answers.

The research was approved by the Bioethics Committee of the Medical University of Białystok (Resolution no. R-I-002/521/2014), Dean of Faculty of Health Sciences of the Medical University of Białystok and the Chairman of the Regional Council of Nurses and Midwives in Bialystok.

\section{STATISTICAL ANALYSIS}

Statistical analysis was done using statistical tests which allowed to verify statistical relevance of con-

Table 1. Burnout syndrome versus education of respondents.

\begin{tabular}{|c|c|c|c|c|c|c|c|c|c|}
\hline \multirow{3}{*}{ CBI } & \multicolumn{9}{|c|}{ Education } \\
\hline & \multicolumn{3}{|c|}{ High school } & \multicolumn{3}{|c|}{ Bachelor } & \multicolumn{3}{|c|}{ Master } \\
\hline & & Me & $s$ & & Me & $s$ & & Me & $s$ \\
\hline $\begin{array}{l}\text { Personal } \\
\text { burnout }\end{array}$ & 48.7 & 50.0 & 15.6 & 49.9 & 50.0 & 17.2 & 46.7 & 45.8 & 18.7 \\
\hline Work burnout & 49.3 & 50.0 & 16.9 & 51.1 & 50.0 & 16.4 & 46.5 & 50.0 & 19.0 \\
\hline $\begin{array}{l}\text { Client/patient } \\
\text { burnout }\end{array}$ & 43.9 & 42.9 & 15.9 & 44.8 & 46.4 & 14.4 & 42.1 & 42.9 & 16.1 \\
\hline Total burnout & 49.7 & 48.7 & 15.7 & 51.1 & 50.0 & 15.4 & 47.4 & 48.7 & 17.2 \\
\hline
\end{tabular}


Table 2. Burnout syndrome versus work experience of respondents.

\begin{tabular}{|c|c|c|c|c|c|c|c|c|c|}
\hline \multirow{3}{*}{ CBI } & \multicolumn{9}{|c|}{ Total seniority [in years] } \\
\hline & \multicolumn{3}{|c|}{ Up to 15} & \multicolumn{3}{|c|}{$16-20$} & \multicolumn{3}{|c|}{$21-25$} \\
\hline & & Me & $s$ & & $\mathrm{Me}$ & $s$ & & $\mathrm{Me}$ & $s$ \\
\hline $\begin{array}{l}\text { Personal } \\
\text { burnout }\end{array}$ & 46.8 & 45.8 & 17.0 & 50.6 & 50.0 & 16.9 & 48.1 & 50.0 & 17.0 \\
\hline Work burnout & 47.2 & 46.4 & 16.2 & 51.3 & 50.0 & 16.3 & 48.7 & 50.0 & 17.8 \\
\hline $\begin{array}{l}\text { Client/patient } \\
\text { burnout }\end{array}$ & 42.9 & 41.1 & 14.2 & 45.5 & 46.4 & 13.9 & 43.2 & 42.9 & 16.1 \\
\hline Total burnout & 48.0 & 44.7 & 15.4 & 51.6 & 51.3 & 14.9 & 49.1 & 50.0 & 16.5 \\
\hline
\end{tabular}

Table 3. Burnout syndrome versus material situation of respondents.

\begin{tabular}{|c|c|c|c|c|c|c|c|c|c|}
\hline \multirow[t]{2}{*}{ CBI } & & good & & & ial sit & & & bad & \\
\hline & & $\mathrm{Me}$ & $s$ & & Me & $s$ & & $\mathrm{Me}$ & $s$ \\
\hline $\begin{array}{l}\text { Personal } \\
\text { burnout }\end{array}$ & 43.0 & 45.8 & 15.8 & 50.6 & 50.0 & 16.6 & 55.8 & 54.2 & 17.8 \\
\hline Work burnout & 43.9 & 46.4 & 18.1 & 51.5 & 50.0 & 15.8 & 53.1 & 53.6 & 18.7 \\
\hline $\begin{array}{l}\text { Client/patient } \\
\text { burnout }\end{array}$ & 41.0 & 42.9 & 15.8 & 44.7 & 46.4 & 14.5 & 46.0 & 46.4 & 17.8 \\
\hline Total burnout & 44.9 & 46.1 & 16.1 & 51.4 & 51.3 & 14.9 & 54.1 & 53.9 & 17.9 \\
\hline
\end{tabular}

Table 4. Burnout syndrome versus having a partner.

\begin{tabular}{|c|c|c|c|c|c|c|}
\hline \multirow{3}{*}{ CBI } & \multicolumn{6}{|c|}{ Having a partner } \\
\hline & & yes & & & no & \\
\hline & & $\mathrm{Me}$ & $s$ & & $\mathrm{Me}$ & $s$ \\
\hline $\begin{array}{l}\text { Personal } \\
\text { burnout }\end{array}$ & 48.8 & 50.0 & 17.2 & 47.2 & 45.8 & 16.1 \\
\hline Work burnout & 49.2 & 50.0 & 17.6 & 48.9 & 50.0 & 15.8 \\
\hline $\begin{array}{l}\text { Client/patient } \\
\text { burnout }\end{array}$ & 43.7 & 42.9 & 15.7 & 43.9 & 46.4 & 14.3 \\
\hline Total burnout & 49.7 & 50.0 & 16.3 & 49.1 & 48.7 & 14.8 \\
\hline
\end{tabular}

Table 5. Burnout syndrome versus age.

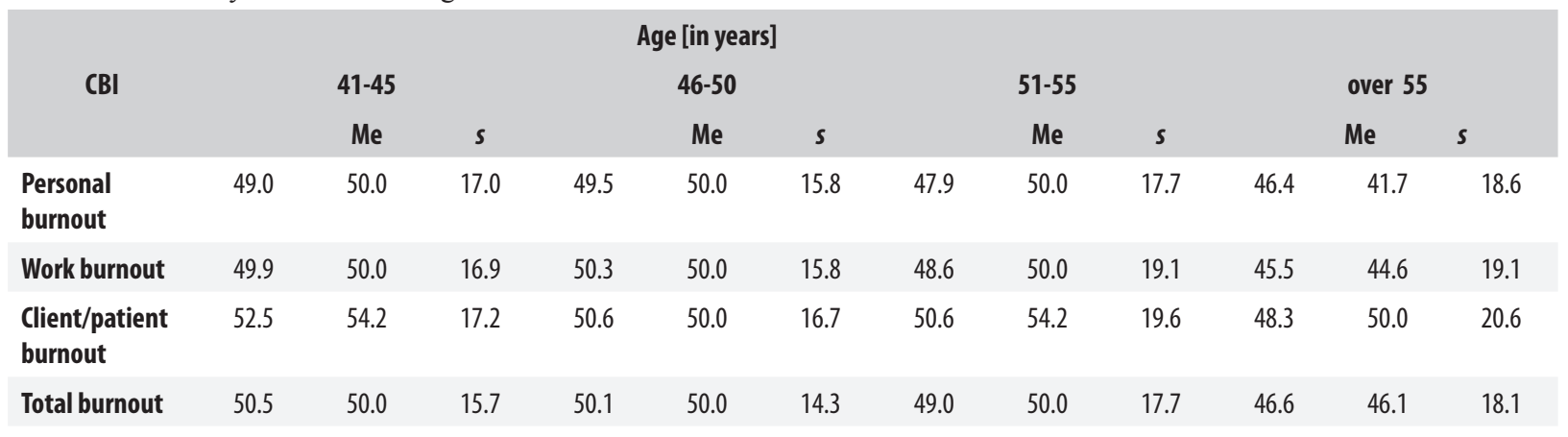

sidered relations. Chi square test of independence was used to assess the relevance of relations between two variables. The Spearman's rank correlation coefficient was applied to test relations between two numerical attributes. The relevance of differences between groups was researched using Mann-Whitney test (for both groups) or Kurskal-Wallis (for three or more groups).

\section{RESULTS}

The influence of chosen factors on self-esteem of work burnout was examined. It cannot be denied that factors like education or experience are meaningless. The details are presented in Tables 1-2.

But it is clearly influenced by financial situation. The women in a worse financial situation experience 
Table 6. Burnout syndrome versus having a specialization.

\begin{tabular}{|c|c|c|c|c|c|c|}
\hline \multirow{3}{*}{ CBI } & \multicolumn{6}{|c|}{ Having a specialization } \\
\hline & & yes & & & no & \\
\hline & & Me & $s$ & & Me & $s$ \\
\hline $\begin{array}{l}\text { Personal } \\
\text { burnout }\end{array}$ & 48.0 & 45.8 & 16.7 & 49.1 & 50.0 & 17.3 \\
\hline Work burnout & 48.1 & 50.0 & 16.5 & 50.1 & 50.0 & 18.0 \\
\hline $\begin{array}{l}\text { Client/patient } \\
\text { burnout }\end{array}$ & 48.8 & 50.0 & 17.5 & 52.8 & 54.2 & 18.3 \\
\hline Total burnout & 48.3 & 48.7 & 15.4 & 50.6 & 50.0 & 16.5 \\
\hline
\end{tabular}

Table 7. Burnout syndrome versus work system.

\begin{tabular}{|c|c|c|c|c|c|c|}
\hline \multirow{3}{*}{ CBI } & \multicolumn{6}{|c|}{ Work shift } \\
\hline & & yes & & & no & \\
\hline & & $\mathrm{Me}$ & $s$ & & Me & $s$ \\
\hline $\begin{array}{l}\text { Personal } \\
\text { burnout }\end{array}$ & 48.7 & 50.0 & 17.1 & 48.2 & 50.0 & 16.7 \\
\hline Work burnout & 49.7 & 50.0 & 17.5 & 47.1 & 50.0 & 16.7 \\
\hline $\begin{array}{l}\text { Client/patient } \\
\text { burnout }\end{array}$ & 52.1 & 54.2 & 18.2 & 47.0 & 45.8 & 17.0 \\
\hline Total burnout & 50.2 & 50.0 & 16.2 & 47.4 & 48.7 & 15.1 \\
\hline
\end{tabular}

Table 8. Burnout syndrome versus work in a clinic.

\begin{tabular}{|c|c|c|c|c|c|c|}
\hline \multirow{3}{*}{ CBI } & \multicolumn{6}{|c|}{ Work in a clinic } \\
\hline & & yes & & & no & \\
\hline & & Me & $s$ & & $\mathrm{Me}$ & $s$ \\
\hline $\begin{array}{l}\text { Personal } \\
\text { burnout }\end{array}$ & 47.4 & 45.8 & 18.4 & 48.8 & 50.0 & 16.8 \\
\hline Work burnout & 44.8 & 46.4 & 19.7 & 49.8 & 50.0 & 16.9 \\
\hline $\begin{array}{l}\text { Client/patient } \\
\text { burnout }\end{array}$ & 50.1 & 50.0 & 20.0 & 51.2 & 50.0 & 17.8 \\
\hline Total burnout & 47.3 & 46.1 & 18.1 & 49.9 & 50.0 & 15.7 \\
\hline
\end{tabular}

Table 9. Burnout syndrome versus work on executive position.

\begin{tabular}{|c|c|c|c|c|c|c|}
\hline & & & Exec & sition & & \\
\hline CBI & & yes & & & no & \\
\hline & & $\mathrm{Me}$ & $s$ & & Me & $s$ \\
\hline $\begin{array}{l}\text { Personal } \\
\text { burnout }\end{array}$ & 49.1 & 50.0 & 18.3 & 48.5 & 50.0 & 16.9 \\
\hline Work burnout & 47.2 & 50.0 & 16.6 & 49.4 & 50.0 & 17.4 \\
\hline $\begin{array}{l}\text { Client/patient } \\
\text { burnout }\end{array}$ & 46.4 & 45.8 & 14.9 & 51.6 & 50.0 & 18.3 \\
\hline Total burnout & 47.6 & 49.3 & 15.0 & 49.8 & 50.0 & 16.1 \\
\hline
\end{tabular}

much higher burnout in almost all considered categories (Table 3).

Having a partner and age do not differentiate the level of work burnout. The details are shown in Tables 4 and 5 .

Nurses with the specialization level are less burned out on area of patients contacts than other surveyed responders (Table 6). The burnout syndrome in the area of contacts experience nurses who are obliged to work in a shift system (Table 7).

People that work in a clinic present a bit smaller level of burnout in work burnout category. The details are presented in Table 8.

People that work on an executive position have a lower level of burnout in the area of patient contacts, moreover it is completely understandable as they def- 
Table 10. Burnout syndrome versus number of places of employment.

\begin{tabular}{|c|c|c|c|c|c|c|c|c|c|}
\hline \multirow{3}{*}{ CBI } & \multicolumn{9}{|c|}{ Places of employment } \\
\hline & & one & & & two & & & more & \\
\hline & & Me & $s$ & & Me & $s$ & & Me & $s$ \\
\hline $\begin{array}{l}\text { Personal } \\
\text { burnout }\end{array}$ & 48.1 & 45.8 & 17.1 & 48.5 & 50.0 & 17.6 & 49.9 & 50.0 & 15.2 \\
\hline Work burnout & 49.3 & 50.0 & 17.8 & 47.8 & 50.0 & 17.7 & 50.3 & 50.0 & 14.5 \\
\hline $\begin{array}{l}\text { Client/patient } \\
\text { burnout }\end{array}$ & 51.1 & 50.0 & 17.8 & 50.5 & 50.0 & 19.0 & 51.1 & 50.0 & 17.0 \\
\hline Total burnout & 49.5 & 48.7 & 16.1 & 48.9 & 50.7 & 16.9 & 50.4 & 50.0 & 13.9 \\
\hline
\end{tabular}

Table 11. Burnout in relation of medical ward category where respondent works.

\begin{tabular}{|c|c|c|c|c|c|c|}
\hline \multirow{3}{*}{ CBI } & \multicolumn{6}{|c|}{ Ward work } \\
\hline & & facility & & & ward & \\
\hline & & Me & $s$ & & $\mathrm{Me}$ & $s$ \\
\hline $\begin{array}{l}\text { Personal } \\
\text { burnout }\end{array}$ & 47.8 & 45.8 & 17.2 & 49.5 & 50.0 & 16.8 \\
\hline Work burnout & 48.9 & 50.0 & 16.7 & 49.5 & 50.0 & 18.1 \\
\hline $\begin{array}{l}\text { Client/patient } \\
\text { burnout }\end{array}$ & 50.4 & 50.0 & 16.9 & 51.7 & 50.0 & 19.2 \\
\hline Total burnout & 49.0 & 47.4 & 15.4 & 50.2 & 51.3 & 16.7 \\
\hline
\end{tabular}

Table 12. Burnout versus shift work.

\begin{tabular}{|c|c|c|c|c|c|c|}
\hline \multirow{3}{*}{ CBI } & \multicolumn{6}{|c|}{ Work on a shift } \\
\hline & & yes & & & no & \\
\hline & & Me & $s$ & & $\mathrm{Me}$ & $s$ \\
\hline $\begin{array}{l}\text { Personal } \\
\text { burnout }\end{array}$ & 48.7 & 50.0 & 17.1 & 48.2 & 50.0 & 16.7 \\
\hline Work burnout & 49.7 & 50.0 & 17.5 & 47.1 & 50.0 & 16.7 \\
\hline $\begin{array}{l}\text { Client/patient } \\
\text { burnout }\end{array}$ & 52.1 & 54.2 & 18.2 & 47.0 & 45.8 & 17.0 \\
\hline Total burnout & 50.2 & 50.0 & 16.2 & 47.4 & 48.7 & 15.1 \\
\hline
\end{tabular}

Table 13. Burnout versus sense of satisfaction from work.

\begin{tabular}{|c|c|c|c|c|c|c|c|c|c|}
\hline \multirow[t]{2}{*}{ CBI } & \multicolumn{8}{|c|}{ Sense of satisfaction } & \\
\hline & & Me & $s$ & & Me & $s$ & & $\mathrm{Me}$ & $s$ \\
\hline $\begin{array}{l}\text { Personal } \\
\text { burnout }\end{array}$ & 62.6 & 66.7 & 14.2 & 50.9 & 50.0 & 15.7 & 43.1 & 41.7 & 16.2 \\
\hline Work burnout & 64.5 & 67.9 & 15.3 & 52.1 & 53.6 & 14.8 & 43.0 & 46.4 & 16.8 \\
\hline $\begin{array}{l}\text { Client/patient } \\
\text { burnout }\end{array}$ & 63.9 & 66.7 & 17.4 & 55.1 & 54.2 & 15.7 & 44.4 & 45.8 & 17.2 \\
\hline Total burnout & 63.7 & 67.1 & 13.9 & 52.7 & 52.6 & 14.1 & 43.5 & 44.7 & 15.1 \\
\hline
\end{tabular}

initely have less of direct contact with patients. The details are given in Table 9.

Number of places of employment has no effect on the level of burnout. (Table 10).

The effect of chosen factors on burnout was researched in the next section.
The type of medical ward where nurse works has no effect on the burnout level of studied nurse. No matter if it is a medical treatment facility or a medical treatment ward, the level of burnout both in a detailed and a general context is similar. The data is portrayed in Table 11. 
Table 14. Work burnout versus sense of satisfaction from financial gratitude.

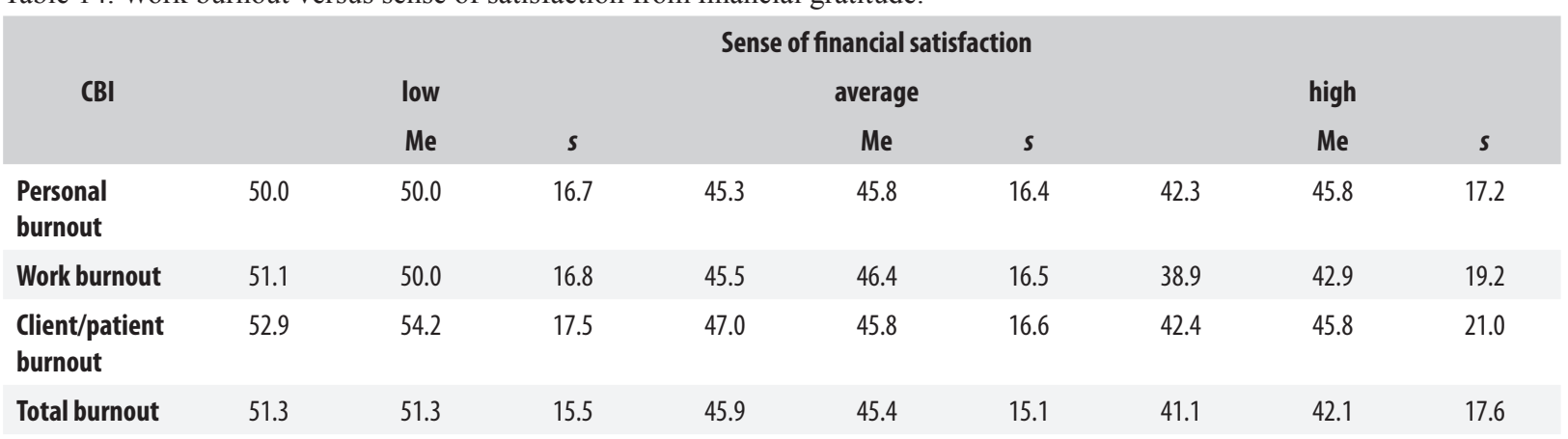

Table 15. Burnout versus work absence.

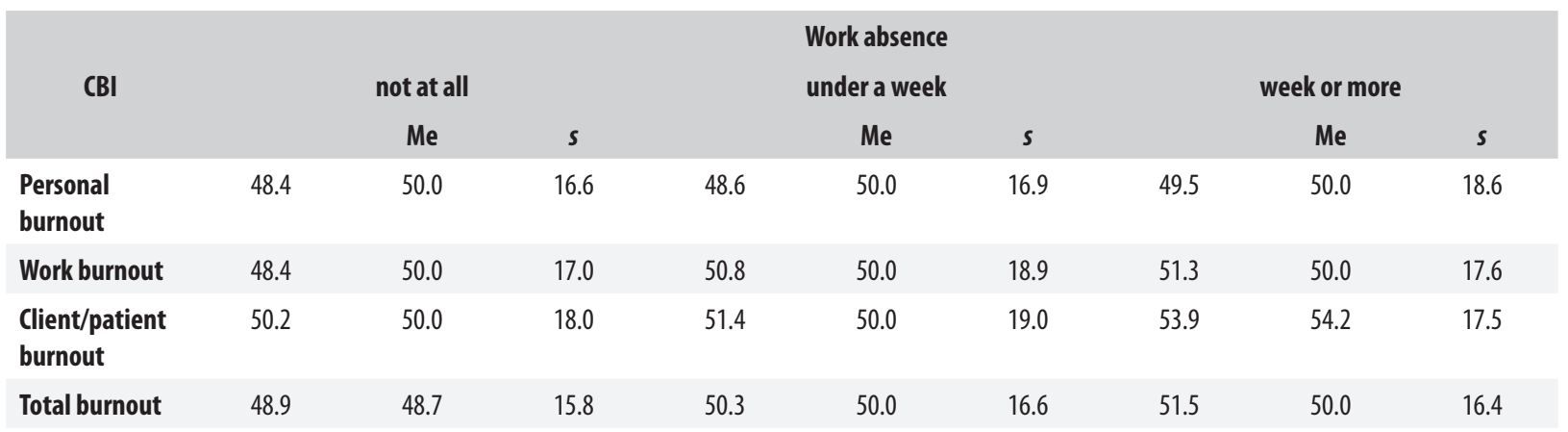

Table 16. Burnout (CBI) of respondents versus level of satisfaction form life (SWLS).

\begin{tabular}{lr}
\multicolumn{1}{c}{ CBI } & SWLS \\
Personal burnout & $-0.35\left(p=0.0000^{* * *}\right)$ \\
Work burnout & $-0.33\left(p=0.0000^{* * *}\right)$ \\
Client/patient burnout & $-0.25\left(p=0.0000^{* * *}\right)$ \\
Total burnout & $-0.34\left(p=0.0000^{* * *}\right)$
\end{tabular}

Fig. 1. Burnout of respondents versus level of satisfaction from life.

The factor which causes an influence on the level of burnout but only in the patient contacts category is shift work. Nurses that work in a shift system complain about higher level of burnout in that aspect (average rate of burnout in that group is around 52 points versus 47 points among nurses that do not work on shift). The detailed numbers are given in Table 12.

The reason that in a very clear way differentiates a level of burnout is a sense of satisfaction from work. Of course, it is hard to determine the cause and result as on the one hand feeling of burnout lowers sense of satisfaction, but on the other handpeople dissatisfied with their labour will much more eagerly see it as symptoms of burnout syndrome. Without searching into this matter deeply it should be stated that relationship between considered aspects is extremely noticeable - nurses that do not get satisfaction from work have level of burnout about 20 points higher than those nurses who declare high sense of satisfaction from work. The details are given in Table 13.
Moreover, it must be stated that not as clearly, but also beyond questions ( $p$ value for all carried out tests below 0.001) the level of burnout depends on the level of satisfaction from financial compensation. Differences between the two opposed groups in the level of burnout increase to 10 points. The numbers are given in Table 14.

The factor that does not influence the level of burnout is absence from work - it could be expected that people who feel burnout syndrome, would more often obtain sick leave, as well as they might be also less resistant on work-related physical difficulties. None of such relations have been noticed, the level of burnout in all three groups researched on the amount of absences at work is quite similar. The exact numbers are presented in Table 15.

It should be also stated that the occurrence of discourage in work which has been assessed using CBI questionnaire contributes to the level of life satisfaction decreases. The higher level of a burnout is presented, the less SWLS values are noticed according to the life satisfaction. These correlations 

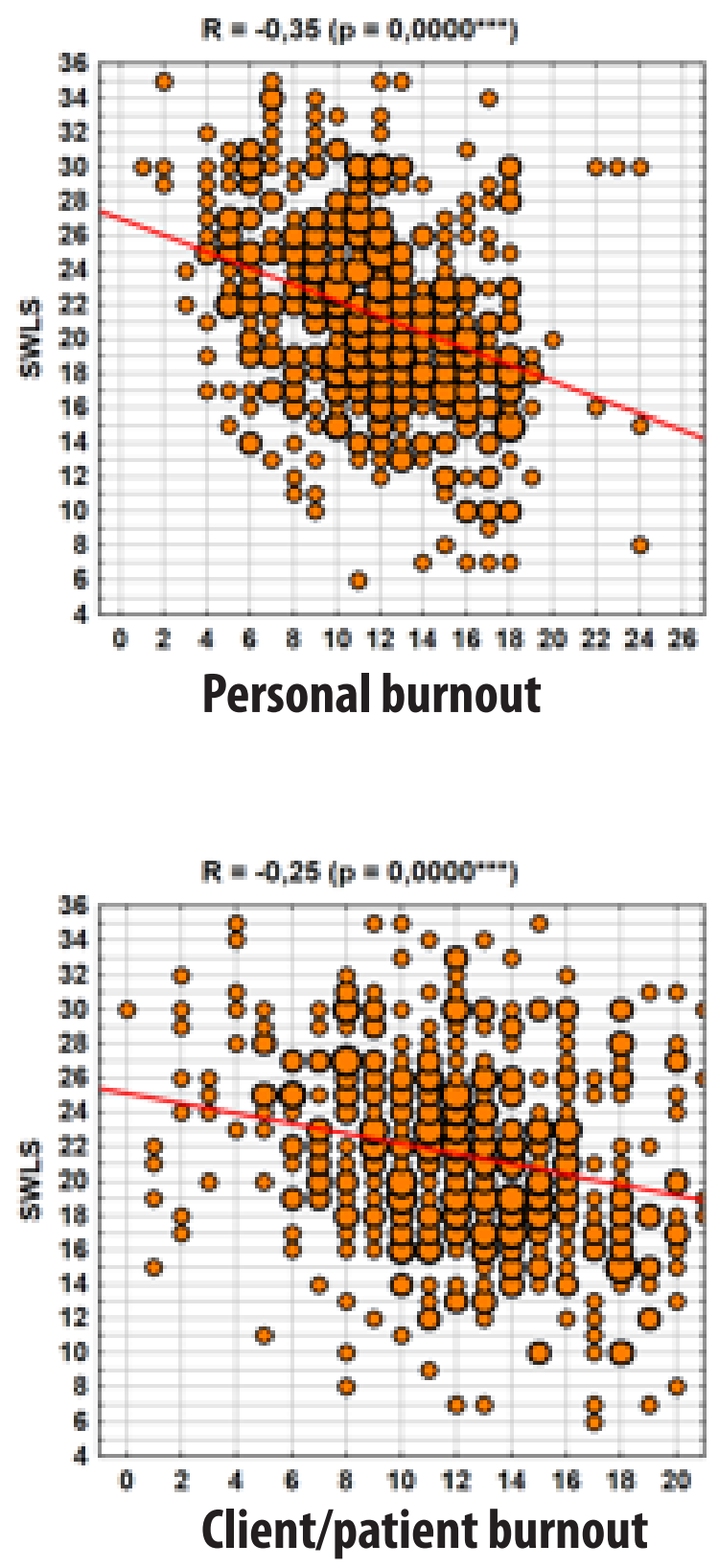

are generally weak, but some of them reach relatively high value ( $\mathrm{R}$ more than 0.30 of the absolute value). The details are reflected in Table 16 and scatter plot (Fig. 1).

\section{DISCUSSION}

Stress which is generally present in the work of nurses is not a direct cause of developing burnout syndrome, it affects especially people that do not have a needed skill to deal with stress and do not receive enough social support [6]. Nitychoruk et al. state that to maintain full professionalism, nurses do
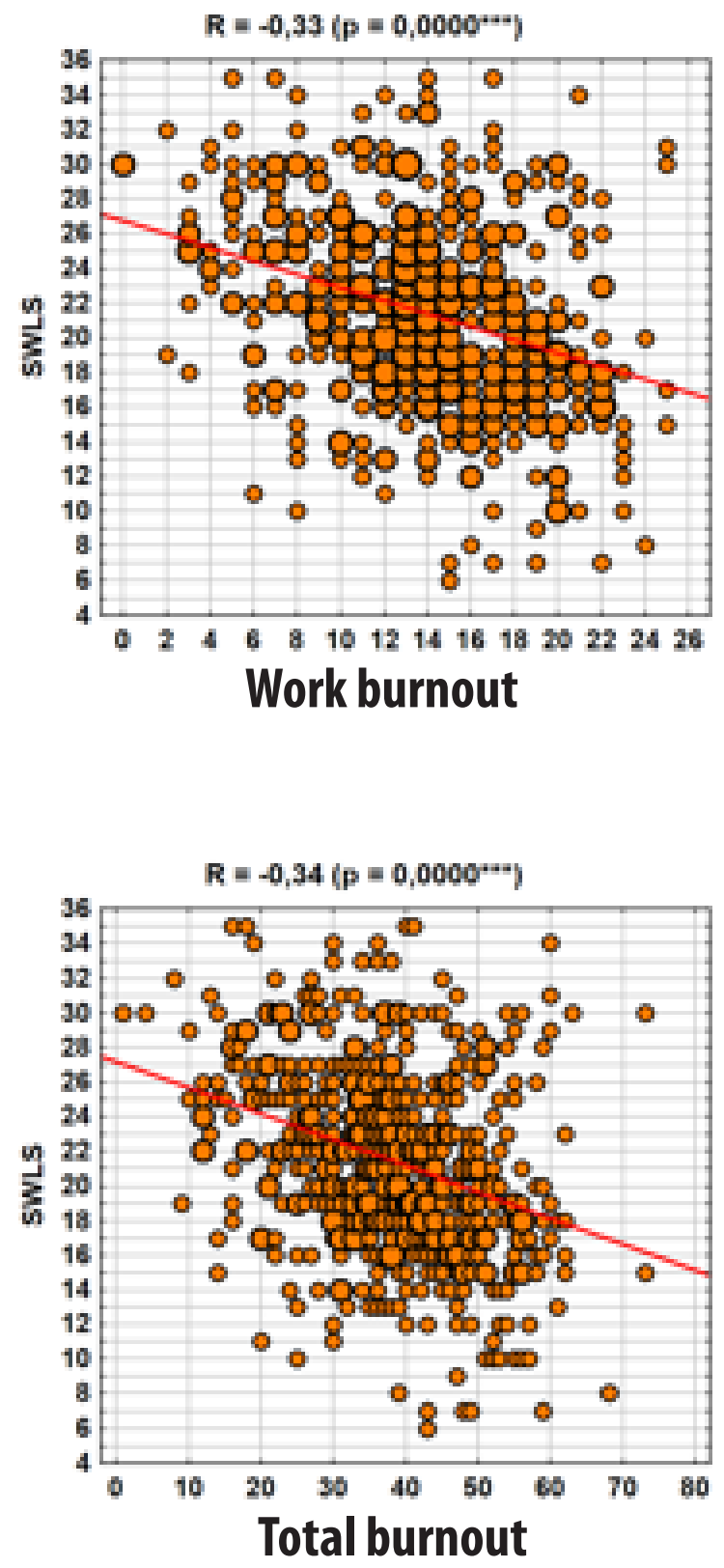

not only have to do their job at the highest level, but it is also essential for them to acquire the ability of behaving in interpersonal relations [7]. The authors claim that in the profession of nurses, both in Poland and across the world the risk of developing burnout syndrome is the highest.

The level of burnout in the researched group, reviewed by using CBI questionnaire is average. The distribution of summarized value measure of burnout is almost perfectly symmetrical, with a dominant group of people who present a medium level of burnout (around $45 \%$ of all respondents). 
The similar results were obtained in the research led by Rezemerska et al. [8]. The increased number of people with burnout developed on medium level and was not influenced by variables like age and seniority. Also, Marcysiak did not notice any influence of age and work experience on development of burnout in nurses [6]. On the other hand, the research conducted by Gwardy et al. stated the effect of seniority on burnout [9]. The staff that worked a longer period of time at ICU has been characterized with more severe burnout symptoms in comparison to people with a shorter seniority.

Our own research has definitely confirmed influence of material situation on the level of burnout in respondents. The women in a worse material situation feel a bigger burnout in almost every considered category. Also, there is no doubt that level of burnout depends on satisfaction from financial gratitude.

The study by Cichońska et al. also proved that inadequate salary is a reason of stress at work according to $76 \%$ of respondents [10]. Among other stressors there were included work overload, demanding attitude of patients, badly organized labour, unfriendly atmosphere and inability or lack of cooperation. According to Kunecka [11] only $25.9 \%$ of tested nurses were satisfied with financial compensation, dissatisfied with that aspect were $54.7 \%$ of respondents. It is confirmed by Kędra and Sanak study in which around $70 \%$ of researched nurses pointed an inadequate salary towards the amount of responsibility [12].

Our own conducted research also, allowed to conclude that nurses who have a specialization are less burned out in the area of patients contacts than the rest respondents who were surveyed.

Sowińska et al. as a result of carried out research stated that lack of professional training contributes to the development of burnout [13]. The authors claimed that higher level of professional non-compliance was observed in nurses with specialization while higher levels of depersonalization and emotional exhaustion were seen in nurses without specialization.

However, Rezemerska et al. [8] showed important statistical differences in the level of burnout because of educational level. $50 \%$ of nurses who achieved a Master's degree had a low level of burnout. On the other hand, high level of burnout was noticed in $19.4 \%$ of nurses with high school education.

The influence of education level on burnout was also proved in the study by Nowak-Starz et al. [14]. The education level in a statistically important value was associated with the level of burnout felt by nurses. The level of burnout was grown considerably with education level. Nurses with high school education felt less burnout if compared to those with Bachelor's degree.

Cipora et al. conducted a study in which they used a group of 128 nurses from Podkarpackie voivodeship [15]. People with a master's degree were characterized with the lowest level rate of burnout but the level of depersonalization and feeling of non-fulfillment were the highest in this group. But for nurses with high school education, the highest level was accomplished in connection with emotional exhaustion. On the other hand, having a specialization in a field of nursing as well as training courses did not differentiate in a statistically relevant way the measure of burnout.

It is believed by Dębska et al. that it is worth undertaking various forms of postgraduate courses because they decrease severity of emotional exhaustion [16].

In our study influence of work system in the process of burnout appearance was pointed out. The burnout in a greater degree experienced nurses that work in a shift system. Nurses that work in that system complained about higher level of burnout but only in an aspect of patients contacts.

Stępień et al. reminded that one of the most common risks of occurring burnout listed in references is shift system [17]. But Rezmerska et al. stated that work shift and single shift work correlate with appearing of burnout syndrome on an average level [8].

The study by Nowak-Starz et al. did not confirm relevant influence of work shift on burnout level, feelings and level of stress and intensification of stressors as well as supporting factors [14]. But place of work had relevant influence on the level of burnout. Nurses that work in treatment departments felt higher stress related to work in comparison to nurses from noninvasive wards.

Also, in our study the relationship between workplace and level of burnout was spotted. People that work in the clinic have a bit smaller level of burnout in field "related to work". Moreover, people that possess management position have a lower level of burnout in the area of patients contacts but it is completely understandable - they probably have a smaller amount of these types of contacts.

Cipora et al. showed that overall indicator of burnout was highest for people that work in a clinic [15]. Nurses from that group more often felt emotional exhaustion and non-fulfillment from work. In study by Nowak-Starz et al. influence of the workplace on burnout level was confirmed [14]. The ward nurses felt the burnout the most severely. In the researched group a work nature and stress related to it, influenced the appearance of burnout and caused a decrease in a 
work satisfaction. Marcysiak et al. proved existence of statistically relevant differences of circumstances conducive to the appearance of burnout in a group of nurses that worked for general healthcare and hospitals [6]. A depersonalization of patients was an observed tendency among medical staff as a result of frequent contacts with patients whose health and life can be threatened. Gwarda et al. realised that in a group of nurses that work on ICU the highest reason for appearing of burnout was organization circumstances, especially work overload [9].

In our research it was realised that work satisfaction is the factor which in a very clear way differentiates the level of burnout. Of course, it is hard to state the cause and the effect - as the feeling of burnout lowers satisfaction from work and vice versa - people dissatisfied from work will easier see burnout syndromes in their dissatisfaction. It must be stated that dependence between considered features is very clearly noticed people that do not feel satisfaction from work have around 20 points higher level of burnout than those nurses that declare high work satisfaction.

The reports from Cichońska et al. results that $90 \%$ of nurses like they work and only $10 \%$ of surveyed do not get a sense of work satisfaction [10].

In turn for surveyed nurses from Podlaskie voivodeship factors like: education and seniority, places of work, ward category, age, relation status turned out to be irrelevant. Also being absent from work do not influence on the level of burnout. It might be expected that people that feel burnout would escape from work or they would feel also less physically resistant to hardships related to work. None of such relations were noticed - level of burnout in three groups categorized by absence days was similar to each other.

Also, the study by Lewandowska and Litwin proved that age and seniority did not significantly influence the appearing of burnout syndrome [18]. But one of the most often symptoms of burnout was: tiredness and exhaustion- symptoms like that were found in $79 \%$ of respondents, $47 \%$ declared a need to get a sick leave and $46 \%$ indicated irritation.

On the other hand, Kędra and Sanak proved that along with age of tested nurses feeling of personal burnout have grown reaching the highest level in the group over 50 years old [12]. Sowińska et al. in the study related to burnout carried out on 96 nurses showed that $54 \%$ of them felt or have been feeling work burnout but $46 \%$ of them have never felt burnt out [13].

Świątkowska states that number of problems related to burnout have direct impact on relations with patients as well as on effectiveness and innovative- ness in pursuing work objectives [1]. The author notices that prevention not only does involve advice communicated to workers but also activities aimed at the improvement of work conditions. A special role is indicated to management staff as through organization of interpersonal trainings or implementing education programs related to the burnout subject, they can cause the prevention of burnout. A special role should be assigned to a correct selection of workers to individual positions, clear determining of professional roles and allocating tasks according to their competence and capacity. Without doubts, the culture of work organization is significant in which positive interpersonal relations are especially valued. Also, system of encouragement to improve knowledge and achieve new skills as well with appropriate remuneration are not without influence on discussed issues.

Group cooperation and support from the loved ones, family remain in a direct relation to struggling with difficult situations. Świątkowska states that difficult situations directly influence mental and physical reactions and changes in behaviour can cause an effect on functioning in private and professional life [1]. Actions taken by person in stress are related to its strength, type and time lasting of it, as well as to the structure of personality, mental immunity, and past experience. The role of support should also be highlighted because people that experience high amount of stress often really require to be supported.

Summarizing, it must be stated that to maintain optimal health is possible only thanks to leading a healthy lifestyle. Moreover, pro-wellness behaviour is one of the key health factors that have an impact on out healthiness. In our research, similarly to other researches it was proved that for women around menopause, the range of behaviours that determine health condition is far from good. Actions to promote correct health behaviours and stress reduction performed regularly on a wide range seem to be an urgent need. Kaleta et al. declare that a low physical activity is a global problem but in that range citizens of Poland, especially in western Europe are dominant [19]. The preventive programs directed to adults can influence changes in a lifestyle and as a consequence lower the amount of diseases which result from incorrect behaviours, increase ability to work and as a result influence on a level of wellness not only an entity but also entire society.

A special role in this range should be given to nurses. As a well-educated group, they have necessary knowledge from the area of healthy lifestyle and promotion of health. Many performed studies confirm that nurses in personal life do not always 
follow rules of a healthy lifestyle and behaviours promoting well-being. Whereas they are members of the public trust profession, they should be role models both in a lifestyle and presented attitude. The fact which is worth mentioning is that one of the most effective methods of affecting the improvement of other people's health is presenting personal behaviours, postures and correct habits. Therefore, nurses should develop skills which will enable them to create, promote and modify other health people's approach and as a result influence on improvement of health, both personal but also of general population $[20,21]$.

\section{CONCLUSIONS}

1. The level of burnout on researched group can be seen as an average.
2. The level of burnout for the respondent was determined by satisfaction from financial gratitude, whereby nurses in a worse material situation felt higher burnout in almost all considered categories.

3. Nurses with specialization were less burned out in the patients' contacts category when compared to other respondents.

4. The level of burnout was clearly differentiated by work system and place of work whereas nurses who work in a work shift system and at hospital wards had a higher level of burnout.

5. Nurses that work on management position had a lower level of burnout in the area of patients' contacts.

6. Feeling of burnout lowered work satisfaction and people dissatisfied with work much easier recognized symptoms of burnout.

\section{REFERENCES}

1. Świątkowska B. Zagrożenia zawodowe pracowników opieki zdrowotnej: Co wiemy i co możemy zrobić? Probl Hig Epidemiol. 2010;91(4): 22-529.

2. Maslach C, Schaufeli WB, Leiter MP. Job burnout; An Rev Psychol 2001;52(1):397-422.

3. Kózka M, Prażmowska B, Dziedzic M, Semczak M. Styl życia kobiet w okresie menopauzalnym - badania wstępne. Przegląd Medyczny Uniwersytetu Rzeszowskiego i Narodowego Instytutu Leków w Warszawie 2013;4:61-4.

4. Kristensen TS, Borritz M. Copenhagen Burnout Inventory. [www.ami.dk/upload/udgivelser/cbi_data uk.pdf - pobrano dnia 02.09.2006, 2-3].

5. Juczyński Z. Narzędzia Pomiaru w Promocji i Psychologii Zdrowia; Pracownia Testów Psychologicznych Polskiego Towarzystwa Psychologicznego Sp. z o.o. 2nd edn, Warszawa, 2009, pp. 128-136.

6. Marcysiak M, Dąbrowska O, Marcysiak M. Wypalenie zawodowe a radzenie sobie ze stresem pielęgniarek. Probl Pieleg 2014;22 (3):312-318.

7. Nitychoruk A, Paszkiewicz J, Van Damme-Ostapowicz K. Wypalenie zawodowe wśród pielęgniarek pracujących w Wojewódzkim Szpitalu Specjalistycznym w Białej Podlaskiej. Probl Pieleg 2015;23(3):332337.

8. Rezmerska L, Kochman D, Anaszewicz A. Specyfika pracy a wypalenie zawodowe w opinii pielęgniarek. Innow Pieleg Nauk Zdr. 2016;1(1):11-26.

9. Gwarda K, Sienkiewicz Z, Kaczyńska A, Gotlib A. Zespół wypalenia zawodowego wśród personelu pielęgniarskiego zatrudnionego w oddziałach intensywnej terapii. Pieleg XXI wieku 2015;2(51):56-60.

10. Cichońska M, Maciąg D, Kucharska K. Ocena przejawów zespołu wypalenia zawodowego wśród pielęgniarek. Acta Sci Acad Ostrov. Sectio B. 2014;3(1):58-72.

11. Kunecka D. Satysfakcja pracownika a jakość usług medycznych. Prob. Hig Epidemiol 2010;91(3):451-457.

12. Kędra E, Sanak K. Stres i wypalenie zawodowe w pracy pielęgniarek. Pieleg Zdr Publ. 2013;3(2):119132.

13. Sowińska K, Kretowicz K, Gaworska-Krzemińska A, Świetlik D. Wypalenie zawodowe i satysfakcja zawodowa w opinii pielęgniarek. Probl Pieleg. 2012;20(3):361-368.

14. Nowak-Starz G, Kozak B, Zdziebło K. Wpływ stresu związanego z pracą zawodową na występowanie zespołu wypalenia zawodowego u pielęgniarek pracujących w oddziałach zabiegowych i zachowawczych. Stud Med. 2013;29(1):15-21.

15. Cipora E, Smoleń E, Gazdowicz L, Maliwiecka T, Poźniak E. Poziom wypalenia zawodowego wśród pielęgniarek pracujących w publicznych zakładach opieki zdrowotnej — badania wstępne. Probl Pieleg. 2014;22(3):252-257.

16. Dębska G, Pasek M, Wilczek-Rużyczka E. Obciążenie psychiczne i wypalenie zawodowe u pielęgniarek pracujących w różnych specjalnościach zawodowych. Hyg Publ Health 2014; 49(1): 113-119. 
17. Stępień R, Nowak-Starz G, Zdziebło K, Wiraszka G. Analiza środowiska pracy pielęgniarek zatrudnionych w oddziałach chirurgicznych w systemie pracy zmianowej w aspekcie zjawiska wypalenia zawodowego. Acta Sci Acad Ostrov. Sectio B. 2014;3(1):73-90.

18. Lewandowska A, Litwin B. Wypalenie zawodowe jako zagrożenie w pracy pielęgniarki. Rocz Pom Akad Med. Szczecin. 2009;55(3):86-89.

19. Kaleta D, Makowiec-Dąbrowska T, Polańska K, Dziankowska-Zaborszczyk E, Drygas W. Palenie tytoniu i inne negatywne zachowania zdrowotne wśród osób czynnych zawodowo. Med Pracy. 2009;60(1):7-14.

20. Rasińska R, Nowakowska I. Postrzeganie zdrowia przez pielęgniarki po czterdziestym roku życia. Pieleg Pol 2014;2(52):111-116.

21. Andruszkiewicz A, Nowik M. Zachowania zdrowotne kobiet czynnych zawodowo. Probl Pieleg 2011;19(2):148-152.

ORCID AND CONTRIBUTIONSHIP*

Bianka Misiak - A,,C,D,E,F

Jolanta Lewko - 0000-0003-3074-1320 A,C,,D,E,F

Regina Sierżantowicz - 0000-0001-8918-9732 B,D,E,F

Karolina Lewko - 0000-0002-1159-0064 B,C,.

Andrzej Guzowski - 0000-0002-4299-5101 B,,C,0

Hady Razak Hady - 0000-0002-0838-3478 A,EF

Jerzy Robert Ładny - 0000-0003-4167-1962 A,E,F

\section{ADDRESS FOR CORRESPONDENCE}

Jolanta Lewko

Zakład Podstawowej Opieki Zdrowotnej

Wydział Nauk o Zdrowiu,

Uniwersytet Medyczny w Białymstoku

ul. Mieszka I 4b, 15-054 Białystok, Poland tel.: 857326820 ,

e-mail: jola.lewko@wp.pl 


\title{
ACUTE CORONARY SYNDROME - ARE WE AWARE?
}

\author{
Mateusz Lech', Paulina Bakier², Sylwia Jabłońska², Rafał Milewski², Emilia Duchnowska', \\ Jerzy Robert Ładny ${ }^{1}$
}

\author{
1 DEPARTMENT OF EMERGENCY MEDICINE, MEDICAL UNIVERSITY OF BIALYSTOK, BIALYSTOK, POLAND \\ 2 DEPARTMENT OF CLINICAL PHONOAUDIOLOGY AND SPEECH THERAPY, MEDICAL UNIVERSITY OF BIALYSTOK, BIALYSTOK, \\ POLAND
}

\section{Abstract}

Introduction: Despite the progress of medicine and the implementation of the latest treatment methods, the problem of Acute Coronary Syndrome (ACS) and the patients' knowledge of the factors favoring the emergence of the disease, manifesting symptoms and providing first aid to a person with suspected myocardial infarction are still part of the discussion not only medical but also economic.

The aim: Assessment of the state of knowledge of patients after cardiac surgery about acute coronary syndromes.

Material and methods: The study evaluated the knowledge of patients after cardiac surgery about acute coronary syndrome. Patients were treated at the Department of Cardiosurgery, University Hospital in Bialystok from January to March 2018. The study involved 60 patients after cardiac surgery, of which 43 were men and 17 were women (aged 37 - 83 years). 0 wn survey consisting of 10 single-choice closed questions and metrics has been used.

Results: The respondents' answers to the questions about risk factors for coronary artery disease were satisfactory due to the fact that as many as $82 \%$ of the respondents indicated the proper reasons for the development of acute coronary syndromes. The respondents had difficulties with questions regarding the provision of first aid in the event of ACS symptoms. When asked if they are willing to change their lifestyle to healthier and safer for their organism - $90 \%$ of respondents expressed a desire.

Conclusions: The basis for forming patient awareness is a good knowledge of factors predisposing to the development of clinical disorders. It is proposed to create expert groups composed of cardiologists, diabetologists, hypertensiologists, psychologists, family doctors, dietitians and other physicians who may adapt the risk assessment to the specificities of individual countries, gender, age and co-morbidities. It has been estimated for reducing mortality that $50 \%$ corresponds to good control of the most important risk factors, and the remaining 50\% are appropriate pharmacotherapy.

\section{INTRODUCTION}

Acute coronary syndrome is a group of symptoms characterized by changes in the coronary circulation, which main feature is a significant restriction or cessation of coronary artery flow [1-2]. The main cause lies in the formation of a blood clot arising as a result of atherosclerotic plaque rupture. The term Acute Coronary Syndrome was formed in the 1980 s as a result of a improved understanding of pathophysiological processes in the event of an exacerbation of stable coronary artery disease [3]. One of the key works of De Wood 'published in the New England Journal of Medicine described the relationship between full-blown heart attack, and coronary thrombus formation. The term ACS covers three clinical types: unstable coronary artery disease, myocardial infarction and some cases of sudden cardiac death [4-6].
The risk of developing ACS increases significantly with age, while the treatment of patients in the elderly is difficult and in many cases controversial. Older people are more often burdened with numerous diseases, thus the treatment is frequently connected with the possibility of numerous complications.

\section{EPIDEMIOLOGY}

One of the largest health issues of the present civilization is the protection of the cardiovascular system, ischemic heart disease, stroke or other diseases occurring in the course of atherosclerotic disease. In Europe, about 4.1 million (46\%) people die each year . Nearly 1.8 million die as a result of coronary heart disease. The fact is that cardiovascular diseases are the most common cause of death for both women and men. According to $\mathrm{WHO}$, the number of deaths from heart attacks in 2020 will exceed 11 million. WHO 
Table 1. The frequency of occurrence of complications in acute stage of acute coronary syndrome depending on their clinical form [4].

\begin{tabular}{lcc}
\multicolumn{1}{c}{ Complication } & NSTEMI (\%) & STEMI (\%) \\
Cardiogenic shock & 1,8 & 7,5 \\
Pulmonary edema & 4,5 & 7,5 \\
Ventricle free wall rupture & 0,1 & 0,6 \\
Ventricule septal rupture & 0 & 0,3 \\
Acute ischemic mitral insufficiency & 0,4 & 0,9 \\
Asystole & 1,5 & 4,9 \\
Persistent ventricular tachycardia & 1,6 & 5 \\
Ventricular fibrilation & 1,3 & 5 \\
Atrioventricular block II and III degree & 1,1 & 4,6
\end{tabular}

also indicates that ischemic heart disease is diagnosed in 30-40 thousand people per 1 million inhabitants in most European countries [7-8].

Symptoms (Table 1):

- retrosternal pain (over $30 \mathrm{~min}$ ) radiating to the left upper limb, neck, mandible, covers the entire front part of the chest, may appear in the epigastrium (burning, choking, tightening pain, high intensity),

- shortness of breath,

- nausea, vomiting

- dizziness,

- increased sweating,

- fear and anxiety,

- pale skin,

- $\quad$ sticky sweat,

- palpitations,

- $\quad$ edema (in people with hypertension).

\section{THE AIM}

The aim of the study was to assess the knowledge and skills of patients after cardiac surgery at different age on the causes and symptoms of acute coronary syndromes.

Research hypothesis: Patient knowledge is low.

\section{MATERIAL AND METHODS}

The research method used in the study was own survey containing 10 single choice questions with the possibility of indicating one correct answer. One of the question was of multiple choice. The questions concerned cardiology, acute coronary syndromes, first aid for patients with suspected myocardial necrosis and patients' ethical attitudes towards their diseases. The choice of the survey as a research method was conditioned by the possibility of thorough examination of a selected group of respondents and it enabled questions to be directed to more subjects at one time than other research methods. The uniform response scheme allowed generalization of the study results for the whole group. Statistical analysis has been performed using the STATISTICA 13 and MICROSOFT EXCEL 2010 software. Patients were treated at the Department of Cardiosurgery, University Hospital in Bialystok, from January to March 2018. The study involved 60 patients after cardiac surgery, of which 43 were men and 17 were women (aged $37-83$ years).

\section{RESULTS}

60 patients participated in the study. Among the respondents, 17 were women $(28 \%)$ and 43 men $(72 \%)$. The youngest respondent was 37 years old and the oldest 83 years old. The average age of respondents was 65 years, median 67 .

Regarding the level of education, the majority $65 \%(\mathrm{n}=39)$ were subjects with secondary or vocational education, $22 \%(\mathrm{n}=13)$ subjects with higher education, while primary education was declared by $13 \%(n=8)$ of the respondents, this group was the least numerous.

Question 1: What is the most common cause of coronary artery disease? Most respondents (77\%) gave the correct answer indicating coronary atherosclerosis.

Question 2: Which of the following factors most likely predispose to acute coronary syndrome? The majority of respondents $(83 \%)$ gave the correct answer indicating smoking, hypertension, diabetes and poor diet.

Question 3: Which of the following symptoms may be evidence of developing acute coronary syndrome? The majority of respondents $(82 \%)$ gave the correct answer indicating chest pain, shortness of breath and weakness.

Question 4: "Bad cholesterol" is called LDL or HDL lipoprotein. Most of the responses given were incorrect. 
In suspected characteristic symptoms of acute coronary syndrome you

should administer:

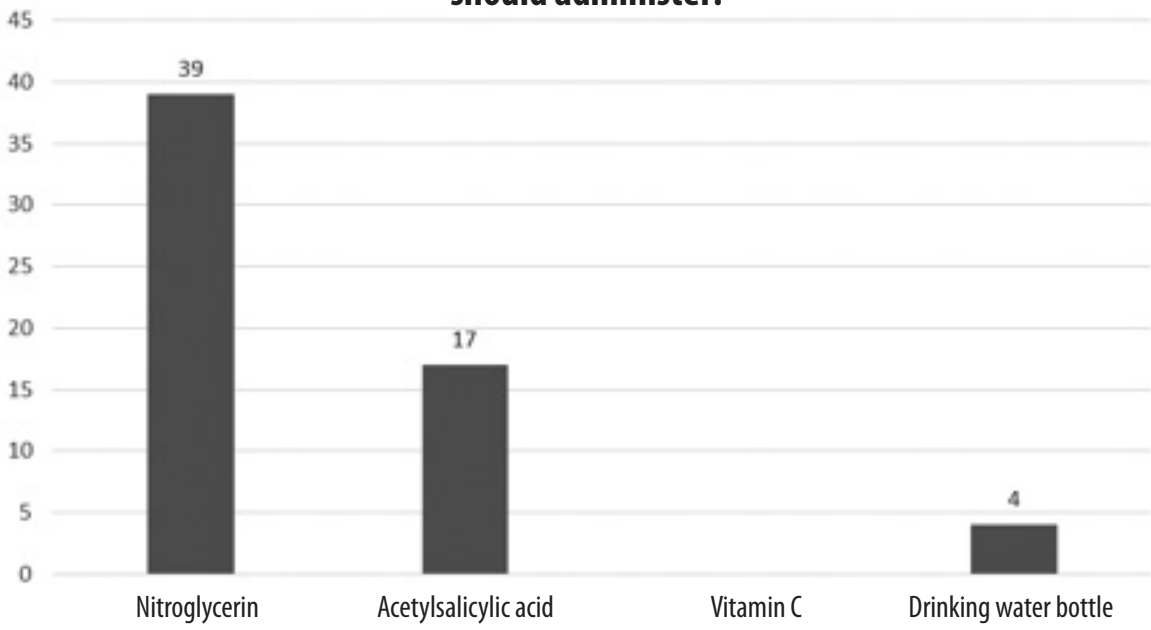

Fig. 1. Question 8 in the survey.

Source: own materials.

Are you willing to change your lifestyle to healthier and safer for your organism after the surgery?

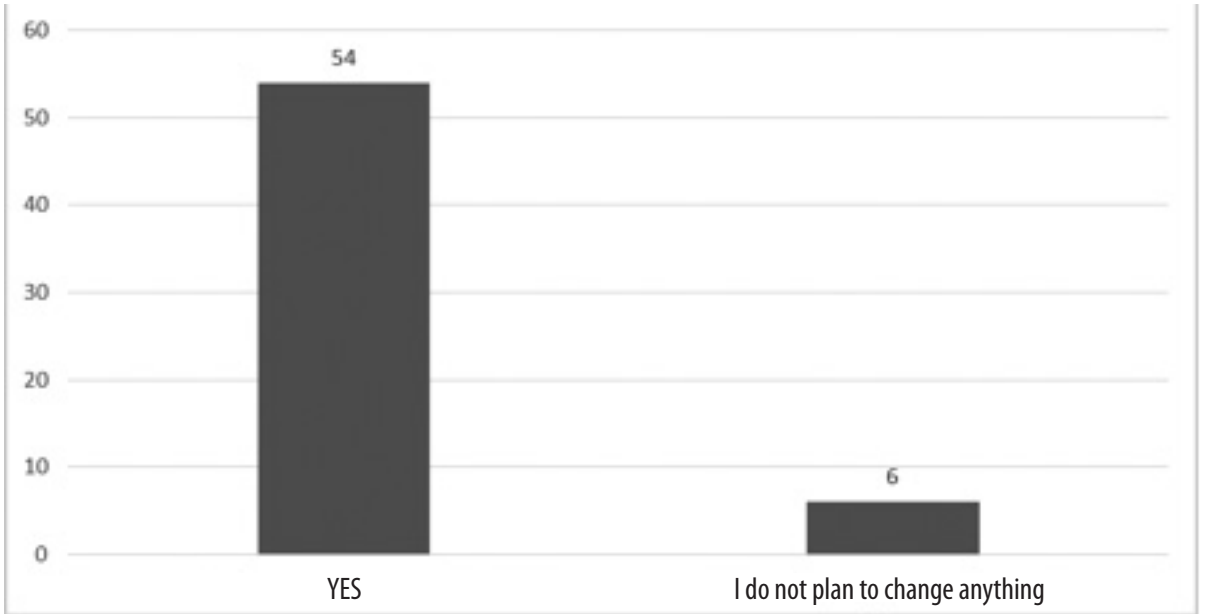

Fig. 2. Question 10 in the survey.

Source: own materials.

Question 5: The optimal adult blood pressure value is. The majority of respondents $(77 \%)$ gave the correct answer.

Question 6: Serum LDL cholesterol threshold values are: Most respondents (70\%) gave incorrect answer.

Question 7: What does the term "visceral fat tissue" mean? Most respondents (67\%) gave incorrect answer.

Question 8: What should you administer the patient when symptoms characteristic for Acute Coronary Syndrome? The vast majority of respondents (78\%) indicated Nitroglycerin as the incorrect answer. Only 22\% indicated acetylsalicylic acid (Fig. 1).

Question 9: Choose the correct emergency number. $97 \%$ of respondents gave the correct answer.
Question 10: Are you willing to change your lifestyle to a healthier and safer for your organism after the surgery? $90 \%$ of respondents gave affirmative answers (Fig. 2).

Respondents have also been asked about risk factors they observed in their lives that could contribute to the development of their disease. The results are presented below.

\section{DISCUSSION}

In cardiovascular diseases, only factors that increase the risk of a disease incident may be identified, while it is worth emphasizing that the absence of these factors does not guarantee failure. Hence the commonly used concept of "risk" factor [9-11]. It is 
worth highlighting that if the patient is unable to influence risk factors of heart disease independent of his/her will, e.g. age - the patient should change those that may be influenced by physical activity, stress reduction or properly balanced diet. A CHECK-UP study in Canada thoroughly confirmed the sense of public education in the prevention of cardiovascular diseases. The subjects were divided into two groups [12]. Group I was standard-treated, while Group II was additionally educated on the methods and importance of lipid control. After several months, the study showed better results of the lipid profile in the educated group, once again confirming the importance of public education in the field of CVD prophylaxis [14-16]. Health education provided by medical staff among patients with hypertension is one of the main elements preventing the development of the disease [17-19].

\section{CONCLUSIONS}

1. The average age of patients undergoing cardiac surgery was 65 years.
2. Among the selected risk factors for coronary artery disease, hypercholesterolemia, diabetes and obesity, hypertension and smoking were the most common.

3. In the study group, a lack of knowledge about acute coronary syndromes has been observed.

4. The respondents present a low level of knowledge in providing first aid to subjects with suspected ACS.

5. The vast majority of respondents expressed a desire to change their lifestyle after the surgery.

6. The recommendation is to introduce advertising campaigns on TV about the causes and preventive measures related to ACS.

7. It is recommended to introduce training for nursing and rescue staff in the field of CVD prevention; as a result, the knowledge passed on to patients could contribute to actual change in their lifestyle after surgery.

The article was created as part of the MA thesis at the Faculty of Health Sciences of the Medical University of Bialystok, major Public Health.

\section{REFERENCES}

1. Galler C (ed.) Polish edn. Pluta J, Wojtylak P, Bohater P. Choroby serca i układu krążenia. MedPharm Polska, Wrocław, 2011.

2. Netter H (ed.) Polish edn. Opolski G. Kardiologia Nettera. ElsevierUrban\&Partner, Wrocław, 2009

3. Michałowska I, Hryniewiecki T, Furmanek MI. Diagnostyka obrazowa, serce i duże naczynia. PZWL, Warszawa, 2014.

4. Gil J, Dudka D. Acute coronary syndromes - diagnostic and therapeutic possibilities, Termedia, Poznań, 2015.

5. Theroux P (ed.) Polish edn. Stępińska J. Ostre zespoły wieńcowe. vol. I, Elsevier Saunders, Poznań, 2012.

6. Szczeklik A, Tendery M. Kardiologia. Medycyna Praktyczna, Kraków, 2009.

7. Chizner MA (ed.) Kardiologia kliniczna. MedMaster, Miami, Floryda, 2010.

8. Frycz-Kurek AM, Buchta P, Szkodziński J. Stabilna choroba wieńcowa - epidemiologia, diagnostyka, wybór postępowania. Chor Ser Nacz 2008;3(5):125-133.

9. Szwed H, Kośmicki M. Farmakoterapia stabilnej choroby wieńcowej. Post Nauk Med 2002;1:15-37.

10. Miernik S, Dziuk M. Metody hybrydowe (SPEC-CT, PET-CT) w diagnostyce choroby wieńcowej i ocenie żywotności mięśnia sercowego. Chor Ser Nacz 2008;5(2):93-101.

11. Montalescot G, Sechtem U, Achenbach S. 2013 ESC guidelines on the management of stable coronary artery disease: The Task Force on the management of stable coronary artery disease of the European Society of Cardiology. Eur Heart J. 2013;34(38):2949-3003.

12. Ochotny R. Leczenie stabilnej choroby wieńcowej. Forum Med Rodz 2007;1(3):221-235.

13. Krejca M, Bis J, Bochenek A. Pomostowanie aortalno-wieńcowe u osób z cukrzycą i niewydolnością nerek. Kardiologia Na Co Dzień 2010;5:159-164.

14. Ribakove GH, Galloway AC, Grossi EA, Colvin SB. Port-access coronary artery bypass. In: Mehmet C (ed.) Minimally inwasive cardiac surgery. Wydawnictwo Springer, NowyJork, 2008.

15. Wilczyńska J, Kochman J, Horoszczuk GJ. Planowe zabiegi rewaskularyzacyjne na naczyniach wieńcowych - przeskórna angioplastyka. Stand Med 2014;11:1136-1143.

16. Kołsut P, Suwalski K, Majstrak F, et al. Pomostowanie tętnic wieńcowych z zastosowaniem technik mniej inwazyjnych. Nowa Med 2009;2:35-40.

17. Misterski M, Perek B, Buczkowski P, et al. Rozwój chirurgicznego leczenia choroby niedokrwiennej serca. Now Lek. 2008;77(2):168-171. 
18. Puchalska-Krotki H, Marcinowska-Suchowierska E. Stabilna choroba wieńcowa w podeszłym wieku odrębności w diagnostyce i leczeniu. Post Nauk Med 2011(5):388-394.

19. Kowalewska-Twardela T, Ziaja K, Urbanek $\mathrm{T}$ et al. Echokardiograficzna próba dobutaminowa u pacjentów z przewlekłą stabilną chorobą wieńcową kwalifikowanych do zabiegów naczyniowych. Chir Pol 2008;10(3-4):133-140.

\section{ORCID AND CONTRIBUTIONSHIP *}

Mateusz Lech - 0000-0002-3401-6479 A,B, C, D

Emilia Duchnowska - 0000-0002-9213-1416

Paulina Bakier - 0000-0001-6425-6943

Sylwia Jabłońska - 0000-0001-9972-5260 D

Rafał Milewski - 0000-0002-2331-6759 D

Jerzy Robert Ładny - 0000-0003-4167-1962 E,F

\section{ADDRESS FOR CORRESPONDENCE}

Mateusz Lech

Zakład Medycyny Ratunkowej

Uniwersytet Medyczny w Białymstoku

ul. Szpitalna 37, 15-295 Białystok, Poland tel: $798-697-717$

e-mail: lech.mateusz10@gmail.com 


\title{
THE ANALYSIS OF SIXTH-YEAR MEDICINE STUDENTS' KNOWLEDGE OF PARAMEDICS COMPETENCIES AND THEIR FIELD OF WORK
}

\author{
Przemysław Marek Fengler, Filip Jaśkiewicz
}

DEPARTMENT OF EMERGENCY MEDICINE AND DISASTER MEDICINE, MEDICAL UNIVERSITY OF LODZ, LODZ, POLAND

\begin{abstract}
The aim: Knowledge about each other roles and responsibilities among healthcare professionals has been indicated as one of the core competencies in collaborative healthcare practice. The primary aim of the study was to recognize and analyze sixth-year medicine students knowledge of paramedic's competencies and field of work.

Material and methods: A questionnaire addressed to sixth-year medicine students from 12 Polish medical universities was used as the evaluation method. The questionnaire consisted of 23 questions. Participants could obtain a maximum number of 48 points. The proportion of $50 \%$ was used to establish a minimum level of correct answers in the study group.

Results: 137 questionnaires were taken into consideration (143 questionnaires in total, 6 excluded due to incomplete survey data). The mean age of the study group was $25.2 \pm 0.2$ years. The mean level of correct answers for the entire study group was $44.31 \pm 20 \%$ ( $\mathrm{Me}=43.75, \mathrm{Q} 25=29.17, \mathrm{Q75}=60.42$ ). The analysis of results identified eight fields in which the percentage of correct answers was statistically significant below the assumed level of $50 \%$.

Conclusions: The sixth-year medicine students' awareness of paramedics' field of work and competencies is insufficient. Eight specific areas of knowledge were distinguished as insufficient: possible educational activities and workplaces, types of intravenous and intraosseous drug delivery routes, unsupervised analgesic drugs and catecholamines available for paramedics, unsupervised intubation in different clinical conditions, pregnancy and childbirth-related procedures and procedures which can be conducted only under physician's supervision.
\end{abstract} Key words

emergency medicine,
education,

emergency medical services

\section{INTRODUCTION}

The State Emergency Medical Service (SEMS) in Poland was established by the Act of State Emergency Medical Service (ASEMS) on the 8th of September 2006 as a reaction to the incident in Katowice in January 2006 and has a relatively young history $[1,2]$. The latest version of the mentioned Act was announced on the 5th of September 2019 [3]. Even though paramedics had been performing their duties and had been educated at Bachelor level before the creation of the SEMS, it was the first law that regulated the profession and clearly stated the purpose of SEMS. The mentioned document provides information about requirements that have to be met in order to become a paramedic. The most important ones are: having full legal rights, being in a good health condition, being fluent in Polish, and receiving proper education [3]. The ASEMS obligates paramedics to update their knowledge and skills, by participating, for example: in additional specialistic courses or conferences [3]. A broad range of powers allows paramedics to work as members of an emergency medical team in an ambulance, air emergency services team, or a medical dispatcher. They can also perform their duties in various health care facilities, such as emergency departments (ED), other hospital wards, primary health care units, trauma, or resuscitation teams. It is also possible for paramedics to use their skills in the army, police, or fire brigades. Executive acts following the ASEMS were published to describe the paramedic's field of work more precisely. The first version of a detailed description of life support management and health care procedures which can be undertaken by paramedics appeared on the 29th of December 2006, and changed in 2009, 2016, and 2019 [4-7]. When these legal acts are compared, one notices how the number of tasks and responsibilities have extended. As a result of the update, the number of drugs that can be administered by paramedics without supervision increased from 24 to 47. Similar updates concern electrical cardioversion and percutaneous stimulation, procedures that at the beginning had to be supervised by a physician.

Taking into consideration numerous places where paramedics can provide medical services, it is cer- 
tain that they have to cooperate with physicians and other employees of the healthcare system. Working as an interdisciplinary team member requires proper communication to transfer knowledge and skills between staff with different competencies and educational backgrounds [8]. However, different academic or training paths amongst medical professionals can also exert a positive impact on the effectiveness of cooperation [8]. Some research shows that interdisciplinary learning and receiving knowledge about the perspective of another healthcare discipline is also valued by students [9]. Since students are usually open-minded, adding interprofessional training to their educational process can change their attitudes towards each other [10]. Moreover, the knowledge about other healthcare professionals' roles and responsibilities is defined as one of the core competencies in collaborative medicine practice [11]. The importance of teamwork in various health care facilities has been previously researched and it has been found that there is a correlation between team performance and the outcome of provided medical services [12]. Some studies indicate that the outcome of good teamwork is the patient's well-being [12-14]. The lack of scientific reports assessing the knowledge of future physicians about the specificity of the paramedics' profession and competencies has prompted us to take an interest in this topic.

\section{THE AIM}

The main goal of this research was to recognize and analyze the knowledge of sixth-year medicine students about paramedics' field of work and competencies.

The specific aims were to assess the knowledge of sixth year medicine students about:

- educational background, an obligation of professional development, teaching qualifications and possible healthcare facilities in which paramedics can work,

- selected medical procedures which can be performed by paramedics with and without supervision: number, types of drugs and their ways of administration, electrotherapy procedures, airway management procedures, pregnancy or labour related procedures and elements of the assessment and monitoring of the patient's clinical condition.

\section{MATERIAL AND METHODS}

A questionnaire addressed to sixth-year medicine students from 12 Polish medical universities was used as the evaluation method. The study lasted from the 1st of October to the 30th of November 2019. The questionnaire consisted of 23 questions in total and included: 2 short-answer questions, 8 multiple-choice questions with one correct answer, and 13 multiple-choice questions with more than one correct answer. Regarding the multiplechoice questions, only selecting all correct answers qualified points to be included in the final result. Participants could obtain a maximum number of 48 points. No negative points were considered in the calculation. The proportion of 50\% (24 points) was used to establish a minimum level of correct answers in the study group. In order to identify areas of knowledge requiring attention, the percentage of correct answers to individual questions was analyzed and results were compared to a proportion of $50 \%$. An electronic way of collecting the data was applied. The survey was anonymous and voluntary.

Statistical analysis of the data was carried out using PQStat, version 1.8.0.324. Quantitative variables are presented using basic descriptive statistics: the arithmetic mean (x), standard deviation (SD) and positional measures - median (Me) and quartiles (Q25 - quartile I, Q75 - quartile III). Participants score was compared to the assumed value of $0.5(50 \%)$ with the t-student test for a single group. Z-test for a single proportion was used to compare results of individual questions to the assumed value of 0.5 . Test probability at $p<0.05$ was considered as significant and test probability at $p<0.01$ was considered as highly significant.

\section{RESULTS}

One hundred and thirty seven questionnaires were taken into consideration (143 questionnaires in total, 6 excluded due to incomplete survey data). The mean age of the study group was $25.2 \pm 0.2$ years. Figure 1. presents the distribution of participants by the university. The mean level of correct answers for the entire study group was $44.31 \pm 20 \%$ $(\mathrm{Me}=43.75, \mathrm{Q} 25=29.17, \mathrm{Q} 75=60.42)$. A highly statistically significant difference was found between the mean result and the assumed level of 50\% defined as the minimum level of correct answers (95\% CI $0.022-0.092 ; p=0.0017)$. The study group responses to individual questions are presented in Table 1. The analysis of results identified eight fields in which the percentage of correct answers was statistically significant below the assumed level of $50 \%$. All of them were multiple-choice questions with more than one correct answer. According to the methodology, only selecting all correct answers 


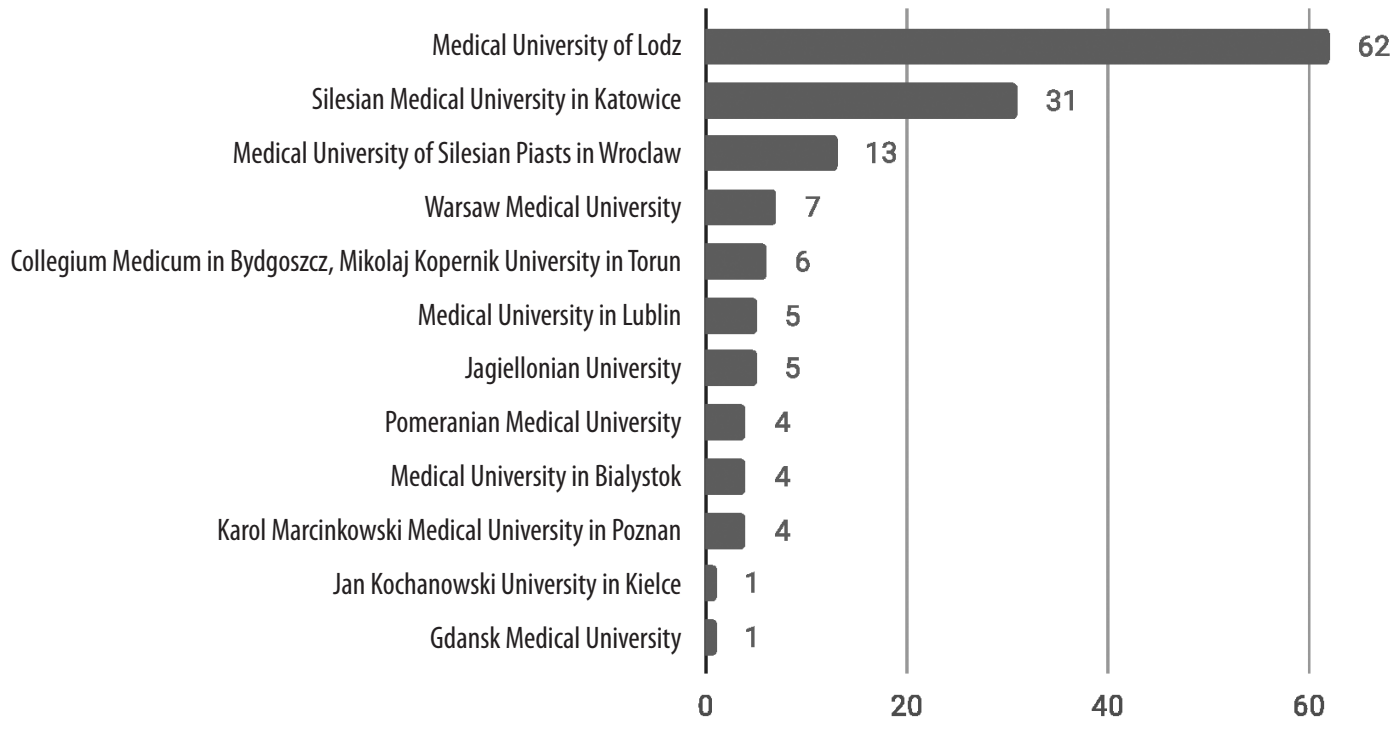

Number of students by university

Fig. 1. Distribution of participants by the university.

Table 1. Analysis of the study group answers to individual questions.

\begin{tabular}{|c|c|c|c|c|c|c|}
\hline Question & $\begin{array}{l}\text { Number of correct } \\
\text { answers }(n=137)\end{array}$ & $\begin{array}{l}\text { Percent of correct } \\
\text { answers }\end{array}$ & $-95 \% \mathrm{Cl}$ & $+95 \mathrm{Cl}$ & Z statistic & $P$ value \\
\hline $\begin{array}{l}\text { What are the current requirements to become a } \\
\text { paramedic? }\end{array}$ & 122 & $89.1 \%$ & 0.825 & 0.937 & 9.056 & $<0.0001$ \\
\hline $\begin{array}{l}\text { Do paramedics have an obligation to update their knowl- } \\
\text { edge as a part of professional development? }\end{array}$ & 130 & $94.9 \%$ & 0.897 & 0.979 & 10.423 & $<0.0001$ \\
\hline $\begin{array}{l}\text { Which educational activities can be conducted by para- } \\
\text { medics without additional teaching qualifications? }\end{array}$ & 41 & $29.9 \%$ & 0.224 & 0.383 & 4.613 & $<0.0001$ \\
\hline Indicate paramedic's possible workplaces. & 40 & $29.2 \%$ & 0.217 & 0.375 & 4.784 & $<0.0001$ \\
\hline $\begin{array}{l}\text { How many drugs can paramedics administer without } \\
\text { physician supervision? }\end{array}$ & 61 & $44.5 \%$ & 0.360 & 0.532 & 1.196 & 0.2317 \\
\hline $\begin{array}{l}\text { What kind of drug administration routes can paramedics } \\
\text { use? }\end{array}$ & 81 & $59.1 \%$ & 0.504 & 0.674 & 2.050 & 0.0403 \\
\hline What type of intra paramedics provide? & 50 & $36.5 \%$ & 0.284 & 0.451 & 3.075 & 0.0021 \\
\hline $\begin{array}{l}\text { What kind of analgesic drugs can be administered by } \\
\text { paramedics without a physician's supervision? }\end{array}$ & 21 & $15.3 \%$ & 0.097 & 0.224 & 8.031 & $<0.0001$ \\
\hline $\begin{array}{l}\text { Which catecholamines can paramedics administer } \\
\text { without physician's supervision? }\end{array}$ & 41 & $29.9 \%$ & 0.224 & 0.383 & 4.613 & $<0.0001$ \\
\hline Can paramedics use muscle relaxants? & 88 & $64.2 \%$ & 0.556 & 0.722 & 3.246 & 0.0012 \\
\hline $\begin{array}{l}\text { Which activities related to electrotherapy can paramedics } \\
\text { perform without a physician's supervision? }\end{array}$ & 80 & $58.4 \%$ & 0.496 & 0.667 & 1.879 & 0.0602 \\
\hline $\begin{array}{l}\text { Which airway management devices can be used by } \\
\text { paramedics? }\end{array}$ & 61 & $44.5 \%$ & 0.360 & 0.532 & 1.196 & 0.2317 \\
\hline $\begin{array}{l}\text { When paramedics can intubate without a physician's } \\
\text { supervision? }\end{array}$ & 38 & $27.7 \%$ & 0.204 & 0.360 & 5.126 & $<0.0001$ \\
\hline $\begin{array}{l}\text { Which activities related to pregnancy and childbirth can } \\
\text { paramedics perform without a physician's supervision? }\end{array}$ & 44 & $32.1 \%$ & 0.244 & 0.406 & 4.100 & $<0.0001$ \\
\hline $\begin{array}{l}\text { What elements of the assessment/monitoring of the pa- } \\
\text { tient's clinical condition can be conducted by paramedics? }\end{array}$ & 122 & $89.1 \%$ & 0.825 & 0.937 & 9.056 & $<0.0001$ \\
\hline $\begin{array}{l}\text { What activities paramedics can perform only under a } \\
\text { physician's supervision? }\end{array}$ & 25 & $18.2 \%$ & 0.121 & 0.257 & 7.347 & $<0.0001$ \\
\hline
\end{tabular}


qualified points to be included in the final result. In each field, the final question results are presented according to the following scheme: the total number of correct answers to individual questions with the percentage results are in brackets. Subsequently, the frequency of each potential answer is given (number of responses and percentage frequency of choice for a given option). In the area of paramedic's educational qualifications, the study group acquired 41 correct answers $(29.9 \%)$ and indicated that paramedics can conduct first aid training $(n=133$, $97.1 \%)$, qualified first aid training $(n=89,65 \%)$ and courses in the field of emergency medical services $(\mathrm{n}=48,35 \%)$. Paramedics can conduct all of those courses without additional teaching qualifications. Another area refers to paramedic's possible workplaces in which the study group presented complete knowledge in 40 cases $(29.2 \%)$. Paramedics can perform their duties in ambulances $(n=136,99.3 \%)$, emergency departments $(\mathrm{n}=132,96.4 \%)$, admission units $(\mathrm{n}=110,80.3 \%)$, hospital wards $(\mathrm{n}=74,54 \%)$, primary healthcare units $(\mathrm{n}=55,40.1 \%)$ and in units reporting to the Minister of Defence $(n=73,53.3 \%)$. It is also possible for paramedics to work as medical dispatchers $(n=120,87.6 \%)$ and take part in medical assistance in mass gatherings $(n=134,97.8 \%)$. A statistically important difference was also identified in the field of intravenous and intraosseous drug delivery routes $(n=50,36.5 \%)$. The study group knew and answered correctly that paramedics can provide routes in distal limb veins ( $\mathrm{n}=137,100 \%)$, external jugular vein $(\mathrm{n}=80,58.4 \%)$ and intraosseous route $(\mathrm{n}=105,76.6 \%)$. Some respondents chose incorrectly that providing intra-arterial $(n=20,14.6 \%)$ and central vein routes $(n=16,11.7 \%)$ by paramedics is possible. The smallest number of correct answers $(n=21,15.3 \%)$ was obtained in the field of unsupervised analgesics use by paramedics. Students were aware that paramedic can administer ibuprofen $(n=129,94.2 \%)$, ketoprofen $(n=128,93.4 \%)$ paracetamol $(\mathrm{n}=134,97.8 \%)$ and opioids: morphine $(\mathrm{n}=69,50.4 \%)$ and fentanyl $(\mathrm{n}=60,43.8 \%)$. Incorrect answers selected by the examined group stated that paramedics can administer ketamine $(n=33$, $24.1 \%)$ and tramadol $(n=67,48.9 \%)$. In the field of unsupervised catecholamines administration participants achieved the result of 41 (29.9\%) correct answers. Some participants $(\mathrm{n}=129,94.2 \%)$ knew that paramedics can administer adrenaline, however administering noradrenaline $(\mathrm{n}=65,47.4 \%)$, dopamine $(n=67,48.9 \%)$, dobutamine $(n=43,31.4 \%)$ and isoprenaline $(\mathrm{n}=20,14.6 \%)$ must be supervised by a physician. A statistical important difference is also visible in the field of intubation ( $\mathrm{n}=38,27.7 \%)$ where the only correct answer is that paramedics can intubate unsupervised in sudden cardiac arrest $(\mathrm{n}=82,59.9 \%)$. In case of anaphylactic reactions $(n=44,32.1 \%)$ and upper respiratory tract burns $(\mathrm{n}=34,24.8 \%)$ paramedics are not permitted to intubate unsupervised. The study group responses in the area of pregnancy and labour related procedures resulted in $44(32.1 \%)$ correct answers. Paramedics can deliver a baby $(\mathrm{n}=129,94.2 \%)$ and manually change the position of the womb $(n=75$, $54.7 \%)$. Nevertheless, conducting a hysterotomy $(\mathrm{n}=12,8.8 \%)$, prenatal examination $(\mathrm{n}=14,10.2 \%)$ and oxytocin administration $(\mathrm{n}=33,24.1 \%)$ are not allowed to perform by paramedics without supervision. In the field of procedures that can be conducted by paramedics only under physician's supervision students indicated: intubation $(\mathrm{n}=47,34.3 \%)$, opioids administration $(\mathrm{n}=57,41,6 \%)$ and carrying out a triage $(n=17,12.4 \%)$. These procedures and this group of drugs can be carried out by paramedics without the oversight of a physician with limitations described in executive acts. Procedures conducted only under supervision are insertion of an intragastric probe $(n=94,68.6 \%)$ and catheterization of the urinary bladder $(n=57,41.6 \%)$.

\section{DISCUSSION}

According to the methodology and based on the study group's total average score of $22.16 \mathrm{pts}$ $(44.1 \pm 20 \%)$, the examined group's knowledge of the paramedic's field of work has been assessed as insufficient. The analysis of data presented 8 specific fields in which the knowledge of the examined group is below the expected level. Possible workplaces indicate that there will be multiple occasions where physicians of many different specializations will have to cooperate with paramedics on a regular basis, for example in hospital wards or primary healthcare units, as well as in the mode of sporadic meetings, for instance, during handoffs in EDs. What is more, dispatchers direct ambulances not only to typical EDs, but also to the hospitals with wards that are prepared to aid patients in specific clinical cases, such as psychiatry or obstetrics departments, where encounters between a paramedic and a physician not associated with emergency medicine occur. The responses of the examined group may suggest that future physicians are incognizant of the fact that cooperation with paramedics will be needed, even when they choose specialization unrelated directly to emergency medicine. A wide range of medical situations that both physicians and paramedics are 
facing, requires proper drugs administration routes that have to be provided. Sufficient knowledge presented by physicians could allow paramedics to ease difficult situations by acting autonomously and by using their full potential in that field. Moreover, it can also prevent situations in which a paramedic is commissioned to perform procedures that they are not trained in. Another significant field concerns analgesic treatment. European Society for Emergency Medicine (EUSEM) pain management guidelines recommend that both in hospital and prehospital phases, pain has to be assessed and treated as soon as possible and with the use of adequate methods [15]. Since Polish paramedics have broad access to analgesic drugs and to the guidelines included in "Good practices of pain management" published by the Ministry of Health, they can and should be expected to use all of their abilities to relieve patient's pain [16]. The insufficient knowledge of the examined group $(n=21,15.3 \%)$ in the mentioned field may result in misapprehension concerning the dosage or the type of used analgesic between paramedics and physicians. Another field where misunderstandings can occur is related to catecholamines usage. Paramedics' eligibility is limited to adrenaline, even though some clinical cases in prehospital care may require an administration of other vasopressors instead [17]. Understanding of alleged restrictions could facilitate cooperation, help avoid incomprehension and possibly create a solution to this problem. A similar situation applies to the intubation field where paramedics can intubate only in sudden cardiac arrest, although in case of anaphylaxis or respiratory tract burns, airway management with the use of endotracheal intubation may be recommended $[18,19]$. The last of the highlighted fields requiring attention concerned procedures that a paramedic can perform only under physician supervision. In relation to this topic, the role of paramedics and physicians as team members is particularly visible. The study group acquired satisfying results $(n=122,89.1 \%)$ in the field of paramedics' education and obligation of professional development ( $\mathrm{n}=130,94.9 \%$ ), which can have a positive impact on the attitude towards partnership, as both professions share mutual - academic background. Improved communication processes that are free of misunderstandings and conflicts, can ameliorate a patient's outcome, minimize medical errors and pursue every medical profession goal - the patient's well-being [20]. The overall results of the study group scored below 50\%, which may indicate an existing need for improvement of understanding paramedics' roles, skills and abilities among sixth-year medicine students. The suggested need could be addressed with interdisciplinary learning implemented in curricula.

Findings of Guraya et al. reported positive outcomes of implementing interdisciplinary education [21]. Eisenmann's et al. simulation-based research consisting of student paramedics, final-year medical students and advanced trainees of emergency nursing has shown that students are willing to change their attitudes towards each other, their behaviors, teamwork and communication, as well as update their medical knowledge [22]. In "Framework for Action on Interprofessional Education and Collaborative Practice" published by WHO it is stated that: "Once students understand how to work interprofessionally, they are ready to enter the workplace as a member of the collaborative practice team. This is a key step in moving health systems from fragmentation to a position of strength." [23]. The rising complexity of patients' healthcare problems requires borderless cooperation between representatives of medical professions. Hypothetically, implementing interdisciplinary learning can improve cooperation between physicians and paramedics and improve patient care [22]

\section{CONCLUSIONS}

The sixth-year medicine students' awareness of paramedics' field of work and competencies is insufficient. Eight specific areas of knowledge were distinguished as insufficient: possible educational activities and workplaces, types of intravenous and intraosseous drug delivery routes, unsupervised analgesic drugs and catecholamines available for paramedics, unsupervised intubation in different clinical conditions, pregnancy and childbirth-related procedures and procedures which can be conducted only under physician's supervision. The impact of medical students' knowledge of paramedics competencies and field of work on a collaboration with paramedics requires further research.

\section{REFERENCES}

1. Ustawa z dnia 8 września 2006 r. o Państwowym Ratownictwie Medycznym. Dz.U. 2006; poz. 1410

2. Sagan A, Kowalska-Bobko I, Mokrzycka A. The 2015 emergency care reform in Poland: Some improvements, some unmet demands and some looming conflicts. Health Policy. 2016;11:1220-1225. doi: https://doi.org/10.1016/j.healthpol.2016.09.009.. 
3. Ustawa z dnia 8 września 2006 r. o Państwowym Ratownictwie Medycznym. T. jedn. Dz.U. 2019; poz. 993, 1590.

4. Rozporządzenie Ministra Zdrowia z dnia 29 grudnia 2006 r. w sprawie szczegółowego zakresu medycznych czynności ratunkowych, które mogą być podejmowane przez ratownika medycznego. Dz. U. $2007 \mathrm{nr} \mathrm{4;}$ poz. 33.

5. Rozporządzenie Ministra Zdrowia z dnia 14 stycznia 2009 r. zmieniające rozporządzenie w sprawie szczegółowego zakresu medycznych czynności ratunkowych, które mogą być podejmowane przez ratownika medycznego. Dz. U. 2009 nr 11; poz. 64.

6. Rozporządzenie Ministra Zdrowia z dnia 20 kwietnia 2016 r. w sprawie medycznych czynności ratunkowych i świadczeń zdrowotnych innych niż medyczne czynności ratunkowe, które mogą być udzielane przez ratownika medycznego. Dz. U. 2016; poz. 587.

7. Rozporządzenie Ministra Zdrowia z dnia 16 grudnia 2019 r. w sprawie medycznych czynności ratunkowych i świadczeń zdrowotnych innych niż medyczne czynności ratunkowe, które mogą być udzielane przez ratownika medycznego. Dz. U. 2019; poz. 2478.

8. Schumtz J, Meier L, Manser T. How effective is teamwork really? The relationship between teamwork and performance in healthcare teams: A systematic review and meta-analysis. BMJ Open. 2018;9(9):23. doi: 10.1136/bmjopen-2018-028280.

9. Burgess A, Kalman E, Haq I et al. Interprofessional team-based learning (TBL): how do students engage?. BMC Med Educ. 2020;20:118. doi: 10.1186/s12909-020-02024-5

10. Merati N, Murphy-Busake A, Alfaro P et al. Professional attitudes in health professions' education: the effects of an anatomy near-peer learning activity. American Association for Anatomy. Anat Sci Educ. 2020. doi: 10.1002/ase.1964.

11. Schmitt M, Blue A, Aschenbrener C et al. Core competencies for interprofessional collaborative practice: reforming health care by transforming health professional's education. Acad Med. 2011;86(11):1351. doi: https://doi.org/10.1097/ACM.0b013e3182308e39.

12. Schmutz J, Manser T. Do team processes really have an effect on clinical performance? A systematic literature review. Br J Anaesth. 2013;110(4):529-544. doi: https://doi.org/10.1093/bja/aes513

13. Reader T, Flin R, Mearns K et al. Developing a team performance framework for the intensive care unit. Crit Care Med. 2009;37(5):1787-1793. doi: 10.1097/CCM.0b013e31819f0451

14. Rosen M, DiazGranados D, Dietz A et al. Teamwork in healthcare: key discoveries enabling safer, highquality care. Am Psychol. 2018;73(4):433-450. doi: 10.1037/amp0000298

15. Hachimi-Idrissi S, Coffey F, Dobias V et al. Guidelines for the management of acute pain in emergency situations. European Society for Emergency Medicine. EUSEM (online) 2020 [download 01.06.2020]; https://www.eusem.org/images/EUSEM_EPI_GUIDELINES_MARCH_2020.pdf

16. Basiński A, Wordliczek J, Woroń J et al. Dobre praktyki leczenie bólu u osób dorosłych w podstawowych zespołach ratownictwa medycznego. Ministry of Health (online) 2019 [download: 01.06.2020]; https:// www.gov.pl/web/zdrowie/dobre-praktyki-leczenia-bolu.

17. Vahdatpour C, Collins D, Goldberg S. Cardiogenic Shock. JAHA. 2019;8(8):e011991. doi: https://doi. org/10.1161/JAHA.119.011991.

18. Truhlar A, Deakin C, Soar J et al. European Resuscitation Council. Guidelines for Resuscitation 2015. Section 4.Cardiac arrest in special circumstances. Resuscitation. 2015;95:148-201.

19. Yoshino Y, Ohtsuka M, Kawaguchi M et al. The wound/burn guidelines - 6: Guidelines for the management of burns. J Dermatol. 2016;43(9):989-1010. doi: https://doi.org/10.1111/1346-8138.13288

20. Topcu I, Turkmen A, Sahiner N et al. Physicians' and Nurses' medical errors associated with communication failures. J Pak Med Assoc. 2017;67(4):600-604.

21. Guraya S, Barr H. The effectiveness of interprofessional education in healthcare: A systematic review and meta-analysis. Kaohsiung J Med Sci. 2018;34(3):160-165. doi: https://doi.org/10.1016/j. kjms.2017.12.009.

22. Eisenmann D, Stroben $F$, Gerken $J$ et al. Interprofessional emergency training leads to changes in the workplace. West J Emerg Med. 2018;19(1):185-192. doi: 10.5811/westjem.2017.11.35275

23. Health Professions Network Nursing and Midwifery Office within the Department of Human Resources for Health. Framework for Action on Interprofessional Education \& Collaborative Practice. WHO (online) 2010 [download 01.06.2020]; https://www.who.int/hrh/resources/framework_action/en/ 
ORCID AND CONTRIBUTIONSHIP *

Przemysław Marek Fengler

$-0000-0002-3098-7550$ A,B,C,,D,E,E,

Filip Jaśkiewicz - 0000-0001-9309-6432 A,E,F

\section{POTENTIAL CONFLICT OF INTEREST}

Filip Jaśkiewicz is a medical consultant for Octopus VR, Lodz, Poland in the project "Development work in the field of VR ACT application enabling the implementation of medical simulations in ALS / PALS training scenarios" which is co-financed by the European Union under the European Regional Development Fund, Action I.2. investments of enterprises in research and innovation. PF has no potential conflict of interest.

\section{FOUNDING}

This research did not receive any specific grant from funding agencies in the public, commercial, or notfor-profit sectors.
ADDRESS FOR CORRESPONDENCE

Przemysław Marek Fengler

Zakład Medycyny Ratunkowej i Medycyny Katastrof, Uniwersytet Medyczny w Łodzi ul. Pomorska 251, 92-209 Łódź, Poland tel.: +48 579667520

e-mail: przemek.fengler@gmail.com

RECEIVED

ACCEPTED

02.07.2020

02.09.2020 


\title{
THE KNOWLEDGE OF STUDENTS OF THE FACULTY
} OF MEDICINE AND THE FACULTY OF EMERGENCY MEDICINE ABOUT INTRAOSSEOUS ACCESS

\author{
Tomasz Męcik-Kronenberg', Aleksandra Joanna Kućc', Katarzyna Krzyżak², Daria Małgorzata Kubik², \\ Klaudia Ewa Kościelecka²
}

\author{
1 CHAIR AND DEPARTMENT OF PATHOMORPHOLOGY, FACULTY OF MEDICAL SCIENCES IN ZABRZE \\ MEDICAL UNIVERSITY OF SILESIA, ZABRZE, POLAND \\ 2 STUDENT RESEARCH GROUP AT THE CHAIR AND DEPARTMENT OF PATHOMORPHOLOGY \\ FACULTY OF MEDICAL SCIENCES IN ZABRZE, ZABRZE, POLAND
}

\section{Abstract}

Introduction: Thanks to more and more modern devices, the intraosseous (I0) access is not difficult, however, the proper determination of the place to effectively obtain this route of drug administration without elementary knowledge may be problematic. In case of any sudden health threat, it is necessary to establish vascular access. However, it is not always possible, or it is very time-consuming, and both factors may worsen the patient's health. In this case, 10 access should be considered. This article presents the results of the examination and comparison of the knowledge of students of medicine and emergency medicine about the 10 access.

The aim: The study aimed to assess the knowledge about 10 access and its comparison among students of medicine and emergency medicine.

Material and methods: 107 students of medicine and 51 students of emergency medicine participated in the study. The original questionnaire containing 16 questions, including 11 scored, was used as the research tool.

Results: Mean percentage of correct answers in students of medicine was $42 \%$, while in students of emergency medicine $-40 \%$ correct answers.

Conclusions: Both groups of respondents in the conducted study showed a low level of knowledge about 10 access. The article draws attention to significant gaps in the education of both groups in the field of basic information of particular practical importance for the performance of the future professional practice.

\section{Key words}

intraosseous access, faculty of emergency medicine, faculty of medicine, level of students' knowledge, respondents

\section{INTRODUCTION}

As early as 1922, the first world reports on the use of intraosseous (IO) access appeared [1]. The issue of IO access was discussed in Chapter 3 of the 2015 Resuscitation Guidelines on advanced life support [2].

One of the key medical procedures in the event of a threat to the life or health of an injured person under various conditions is quick and effective access to the circulatory system [3]. Thanks to more and more modern devices, the implementation of the IO access is not difficult, however, the proper determination of the place to effectively obtain this route of drug administration without elementary knowledge may be problematic [4]. The IO access is indicated in the case of any sudden health threat in which vascular access is necessary, and the intravenous access is impossible or very time-consuming, which may deteriorate the patient's health $[5,6]$. Performing the IO access thanks to the use of a ready-made mechanical device takes less time compared to the traditional cannulation of peripheral blood vessels $[7,8]$. The reason for the impossibility of inserting a peripheral venous catheter may be the patient's clinical condition - hypovolemic shock, cardiac arrest, hypothermia, burns, as well as the state of limited access to the casualty, e.g. jamming as a result of a traffic accident [3].

The analyzed method was initially used only in pediatric patients. Currently, it is considered effective also in adults [8-16].

Many authors report that pain sensations increase with an increase in infusion pressure (using a rapid transfusion set) and with an increase in the volume of the transfused fluid, but the puncture procedure itself is associated with little pain [6]. Drugs administered with this method achieve adequate plasma concentrations in a time comparable to the administration by the intravenous route [17-18]. Adrenaline is one of the drugs, which achieves higher concentrations in a 
shorter time with intravenous, not IO administration, and its pharmacokinetics in the IO administration to the sternum, is similar to the pharmacokinetics with intravenous administration (as demonstrated in animal studies) [19].

As in almost every medical procedure, it is worth mentioning the contraindications. These include, among others: inability to locate the access site, wounds, tumors and skin inflammation in the vicinity of the puncture site, as well as soft tissue infection at the site of the access, osteoporosis, congenital bone fragility, osteomalacia and compartment tightness syndrome [20-22]. The following complications should not be forgotten: subperiosteal infusion as a result of improper needle penetration, osteomyelitis, sepsis, bone fracture, or compartment tightness syndrome. However, there are many studies showing the high efficiency of obtaining IO access at the first attempt, reaching even $80 \%$ [23].

\section{THE AIM}

Obtaining IO access is associated with the knowledge of procedure algorithms and the experience of people providing medical rescue activities as well as clinical knowledge about indications, contraindications, possibilities, and effects of gaining IO access. Due to the scarce number of publications on this subject, the research was undertaken to assess the level of knowledge about IO access and its comparison among students of medicine and emergency medicine.

We aimed to answer to the following questions:

1. Did the studied group of students show the same level of knowledge about obtaining IO access?

2. Do the faculty (medicine vs emergency medicine) type and gender of respondents influence on the knowledge about IO access procedures?

3 . Is the year of study and thus the acquired knowledge relevant to the knowledge of the procedures for IO access?

4. Is it advisable to take measures to increase the level of knowledge among students of both the medicine faculty and the emergency medicine faculty in the field of IO access in order to improve the provision of emergency healthcare activities?

\section{MATERIAL AND METHODS}

We enrolled 107 students of medicine (Table 1) and 51 students of emergency medicine (Table 2) from all over Poland (Medical University of Gdańsk, Karol Marcinkowski University in Poznań, Medical University of Łódź, Medical University of Silesia, Medical University of Lublin, Medical University in Białystok, Medical University of Warsaw, University of Opole, Jan Kochanowski University in Kielce, Pomeranian Medical University, Jagiellonian University Collegium Medicum, University of Technology and Humanities in Radom, University of Rzeszów, University of Warmia and Mazury in Olsztyn, Krakow Medical Academy Andrzej Frycz Modrzewski, State University in Biała Podlaska, two foreign universities, Siedlce University of Natural Sciences and Humanities, Academy of Physical Education in Warsaw, State University of Nysa, Medical College in Sosnowiec, Collegium Medicum in Bydgoszcz) - 19 universities in total.

The research was conducted from January to February 2020. The method of diagnostic survey was used [24], in which a specially developed proprietary questionnaire was applied as the research tool. The group of respondents included 107 students of medicine and 51 students of emergency medical services. Thus, the study group consisted of 158 people. The questionnaire completed independently by respondents was anonymous and participation in it was completely voluntary. The survey consisted of two parts. The first one contained 5 non-scored questions, covering variables such as the gender, faculty, year of study, the name of the university, and the question about the source of the knowledge gained so far. Its aim was to characterize the research group. The second part contained 11 scored questions and concerned the general level of students' knowledge about the performance of IO access. The maximum number of points was 15 .

The respondents were to answer such questions as: What is the recommended puncture place in children up to 6 years of age? Which of the following drugs must not be administered intraosseously in children? What are the indications for an IO access?

For statistical calculations, Microsoft Office Excel 2010 was used. The Pearson correlation coefficients (a linear relationship between two variables) and the Spearman correlation coefficients (rank correlation in terms of a two-dimensional feature) were used to determine the degree and strength of interdependence, which quantified the degree of these interdependencies. $\mathrm{P}<0.05$ was adopted as the level of significance. The qualitative and quantitative analysis of the obtained data is the basis for the description of the results and the achievement of the work objective.

\section{RESULTS}

The group of respondents was analyzed in terms of the following factors: gender, faculty, university, and year of study. There was no correlation between 
Table 1. The number and percentage of students of medicine by the given university.

\begin{tabular}{|c|c|c|}
\hline University name & Number & Percentage (\%) \\
\hline Medical University of Silesia in Katowice & 35 & $32.7 \%$ \\
\hline Medical University of Gdańsk & 10 & $9.3 \%$ \\
\hline Karol Marcinkowski University in Poznań & 7 & $6.5 \%$ \\
\hline Medical University of Łódź & 13 & $12.1 \%$ \\
\hline Medical University in Białystok & 4 & $3.7 \%$ \\
\hline Warsaw Medical University & 13 & $12.1 \%$ \\
\hline University of Opole & 2 & $1.9 \%$ \\
\hline Jan Kochanowski University in Kielce & 3 & $2.8 \%$ \\
\hline Pomeranian Medical University & 2 & $1.9 \%$ \\
\hline Jagiellonian University Collegium Medicum & 2 & $1.9 \%$ \\
\hline University of Technology and Humanities in Radom & 1 & $0.9 \%$ \\
\hline Medical University in Lublin & 3 & $2.8 \%$ \\
\hline University of Warmia and Mazury in Olsztyn & 8 & $7.5 \%$ \\
\hline Krakow Medical Academy Andrzej Frycz Modrzewski & 1 & $0.9 \%$ \\
\hline Collegium Medicum in Bydgoszcz & 1 & $0.9 \%$ \\
\hline Foreign universities & 2 & $1.9 \%$ \\
\hline
\end{tabular}

Table 2. The number and percentage of students of emergency medicine by the given university.

\begin{tabular}{lcc}
\multicolumn{1}{c}{ University name } & Number & Percentage (\%) \\
\hline Medical University in Kódź & 12 & $23.5 \%$ \\
Warsaw Medical University & 9 & $17.6 \%$ \\
Siedlce University of Natural Sciences and Humanities & 12 & $23.5 \%$ \\
State University of Nysa & 2 & $3.9 \%$ \\
State University in Biała Podlaska & 3 & $5.9 \%$ \\
University of Rzeszów & 1 & $2 \%$ \\
Medical University in Gdańsk & 3 & $5.9 \%$ \\
Medical College in Sosnowiec & 1 & $2 \%$ \\
Academy of Physical Education in Warsaw & 1 & $2 \%$ \\
Jagiellonian University & 1 & $2 \%$ \\
Jan Kochanowski University in Kielce & 6 & $11.8 \%$
\end{tabular}

the first three factors and the result obtained (respectively: $p=0.780 ; p=0.617 ; p=0.110)$. In relation to the year of study of the medicine faculty, the results were achieved at the significance level of $p=0.006$, and in the field of emergency medicine faculty at the significance level of $p=0.020$, which were statistically significant. The group of respondents included 107 students of medicine and 51 students of emergency medicine. In total, there were enrolled 158 people, including 117 women (74.1\%) and 41 men 
$(25.9 \%)$. The results were analyzed in terms of the year of study. Second (30.4\%) and third (24.7\%) year students were the most numerous group of respondents. First-year students accounted for $10.8 \%$, fourth year $-18.4 \%$, fifth year $-5.1 \%$, and sixth $-10.8 \%$ (Fig 1). The best results in the group of medicine students were obtained by respondents at the fifth year
(Fig. 1), and in the case of emergency medicine - at the third year (Fig. 2).

$106(67.1 \%)$ students obtained knowledge about IO access in classes, and 75 students (47.5\%) - from other sources (books, internet, articles), while only 23 students (14.6\%) gained knowledge during their internships (Figure 3).

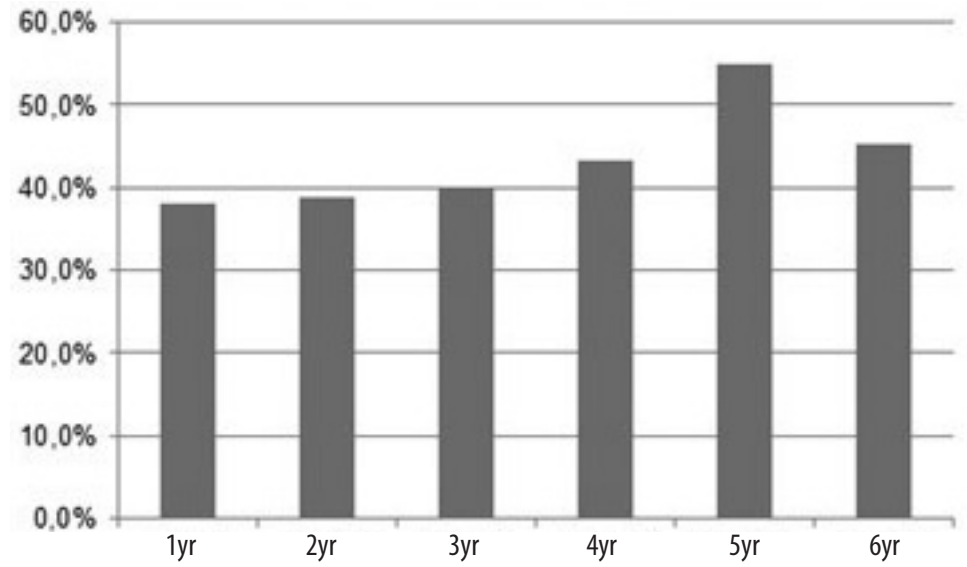

Fig. 1. Correct answers in percentage obtained on average by students of medicine depending on the year of study.

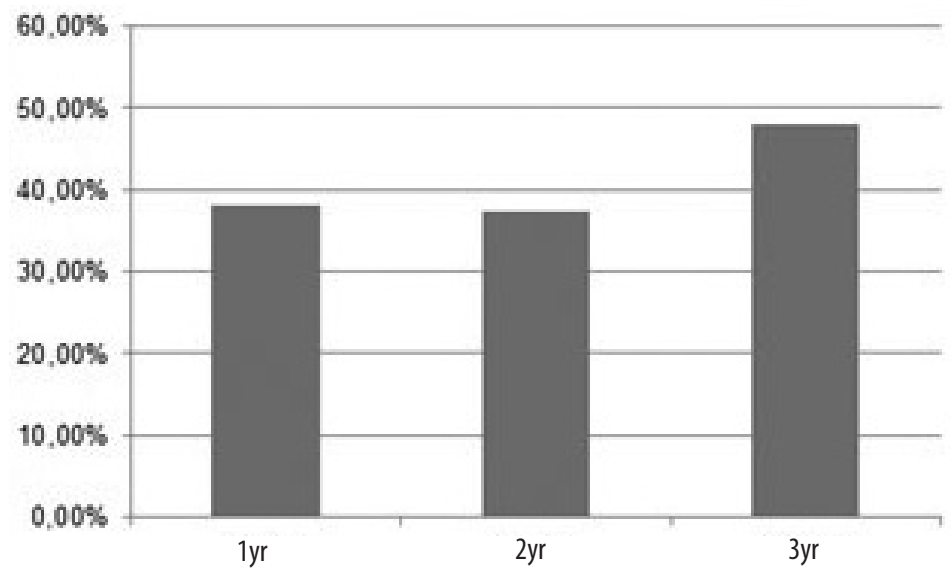

Fig. 2. Correct answers in percentage obtained on average by students of emergency medicine depending on the year of study.

\section{Where did you gain the knowledge about intraossesous access?}

158 answers

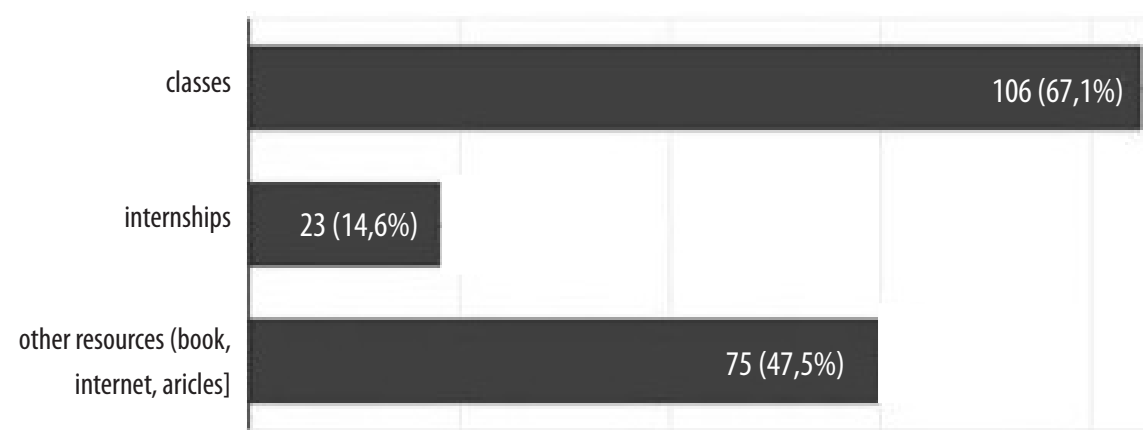

Fig. 3. Students' answers in percentage to the question: Where did you gain knowledge about intraosseous access? 
The surveyed students of medicine obtained the mean result of $42.0 \%$, while students of emergency medicine obtained $40.0 \%$ of correct answers. The range of obtained results was from $20 \%$ (3/15 points) to $100 \%$ ( $15 / 15$ points), and from $0 \%(0 / 15$ points $)$ to $100 \%$ (15/15 points), respectively. The most frequently obtained result was 7 points - it was obtained by 31 respondents. Only 11 students were able to answer the question about the places of obtaining IO access (a multiple choice question) correctly - this question was therefore the most difficult for students of both medicine as well as emergency medicine. Only 17 respondents $(10.8 \%)$, including 5 future paramedics $(9.8 \%)$ and 12 future doctors (11.2\%) knew that decompensated circulatory and respiratory failure was the indication for IO access. Thus, it was one of the questions with the highest number of incorrect answers. On the other hand, 40 students of emergency medicine $(78.4 \%)$ and 92 students of the medicine $(86 \%)$ answered correctly the question about contraindications within the planned IO access site. Slightly more than half of the students of emergency medicine and students of medicine obtained $35(68.6 \%)$ and 69 $(64.4 \%)$ correct answers, respectively, regarding the time in which fluid therapy should be administered in the victim. Knowledge about possible complications was demonstrated by $30(58.8 \%)$ future paramedics and 77 future doctors $(72 \%)$. One of the questions with the highest number of correct answers concerned the possible consequences of failure - 142 respondents $(89.9 \%)$ answered it correctly. The question with the greatest number of incorrect answers concerned the time of maximum maintenance of IO access. Only 21 surveyed paramedics $(41.2 \%)$ and 52 doctors $(48.6 \%)$ answered it correctly. 107 respondents $(67.7 \%)$ had knowledge about patients for whom the puncture site on the tibia should be changed. However, only 27 students of emergency medicine (52.9\%) and 41 students of medicine $(38.3 \%)$ knew where the puncture site was recommended in children under 6 years of age. 33 paramedics $(64.7 \%)$ and 71 physicians $(66.3 \%)$ correctly answered the following question "The place of IO access in the tibia in adults is ....". It is alarming that only 80 of all respondents $(50.6 \%)$ knew which drug could not be administered intraosseously, and 31 $(19.6 \%)$ and $44(27.8 \%)$ indicated as such atropine and adrenaline, i.e. basic drugs administered, inter alia, intraosseously in emergency medicine (Table 3 ).

Table 3. Comparison of correct answers in numbers (percentage) provided by students of medicine and emergency medicine.

\begin{tabular}{|c|c|c|c|}
\hline Question & Correct answer & $\begin{array}{l}\text { Emergency Medicine } \\
\text { Faculty }\end{array}$ & Medicine Faculty \\
\hline $\begin{array}{l}\text { What are the sites of } 10 \text { access? combination of } \\
\text { answers }\end{array}$ & $\begin{array}{l}\text { The sternum in median line; radius; medial ankle } \\
\text { of the tibia; humerus; the area of the tuberosity of } \\
\text { the tibia }\end{array}$ & $2(3.9 \%)$ & $5(4.7 \%)$ \\
\hline What are the indications for an 10 access? & decompensated cardiopulmonary failure & $5(9.8 \%)$ & $12(11.2 \%)$ \\
\hline $\begin{array}{l}\text { What are the contraindications (within the planned } \\
\text { access site)? }\end{array}$ & signs of soft tissue infection & $40(78.4 \%)$ & $92(86.0 \%)$ \\
\hline $\begin{array}{l}10 \text { access is recommended for every injured person } \\
\text { who requires fluid therapy. For what time? }\end{array}$ & 5 minutes & $35(68.6 \%)$ & $69(64.4 \%)$ \\
\hline What are the possible complications? & $\begin{array}{l}\text { The tightness syndrome of the fascial compart- } \\
\text { ments }\end{array}$ & $30(58.8 \%)$ & $77(72.0 \%)$ \\
\hline What are the possible consequences of failure? & Bone perforation & $47(92.1 \%)$ & $95(89.0 \%)$ \\
\hline $\begin{array}{l}\text { What is the optimal maintenance time for an } 10 \\
\text { access? }\end{array}$ & 24 hours & $21(41.2 \%)$ & $52(48.6 \%)$ \\
\hline $\begin{array}{l}\text { In which patients the tibia puncture site is } \\
\text { changed? }\end{array}$ & For children under 6 and older women & $32(62.7 \%)$ & $75(70.0 \%)$ \\
\hline $\begin{array}{l}\text { Where } 10 \text { access is recommended for children under } \\
6 \text { years? }\end{array}$ & tibia & $27(52.9 \%)$ & $41(38.3 \%)$ \\
\hline The sites for 10 access in the tibia in adults are: & $\begin{array}{l}1-2 \mathrm{~cm} \text { medially and } 1 \mathrm{~cm} \text { proximal to tuberosity } \\
\text { of the tibia }\end{array}$ & $33(64.7 \%)$ & $71(66.3 \%)$ \\
\hline $\begin{array}{l}\text { Which of the following drugs must not be adminis- } \\
\text { tered intraosseally in children? }\end{array}$ & 8.4\% NaHCO3 & $31(60.8 \%)$ & $49(45.8 \%)$ \\
\hline
\end{tabular}




\section{DISCUSSION}

The initiation of pharmacological therapy as a part of medical rescue activities plays a key role in treatment. It is the duty of every physician and paramedic to know how to obtain IO access properly. They always try to obtain intravenous access as soon as possible, or when it is impossible - intraosseous one. Therefore, it is advisable to explore their knowledge in this field and to constantly improve the skills of the proper implementation of this procedure. The cooperation between the heads of specialist EMS teams and paramedics, as well as doctors performing duties in hospitals, is more and more frequent, therefore it is absolutely necessary to know the procedures and functioning of various methods of obtaining the IO access. The survey showed significant shortcomings in this field among students of medicine as well as emergency medicine at medical universities and colleges throughout Poland. Despite the available information on the access site, indications and contraindications, the study curriculum (apart from anesthesiology and emergency medicine implemented only in the 5th and 6th year of medical studies and EMS procedures in the 4th and 5th semester in the field of medical emergency) does not provide the transfer of knowledge to future doctors and paramedics on this topic. The study was aimed to verify the hypothesis, which was confirmed in the opinion of the authors, based on the questionnaire. The single-choice test (one multiple-choice question), which did not exceed the basic content of the 2015 Resuscitation Guidelines, was solved at a very low level. In the study by Szarpak and co-authors, the knowledge of IO access was assessed among 60 junior doctors participating in training in emergency medicine. According to him, as many as $71.7 \%$ of the respondents did not take practical and theoretical classes in this field during their studies. However, all people they surveyed believed that such training should be mandatory for medical personnel. The authors summarizing the article pointed to the need to introduce IO access training and considered the knowledge of younger doctors insufficient [25]. The aspects that at least $70 \%$ of the respondents in both groups dealt with were the knowledge about the contraindications for the insertion of the IO access within the planned access site and the possible consequences of failure. Many advantages of IO access are described [2], e.g.: speed (insertion takes 60-90 seconds), ease (failure rate $<5 \%$ ), safety (in the case of administration to the sternum, the infusion tube is placed at a safe depth $-1.5 \mathrm{~cm}$ below the cervical sternum). Also, it ensured an adequate transfusion rate $(30 \mathrm{~mL} / \mathrm{min}$ with a standard transfusion set, 125 $\mathrm{mL} / \mathrm{min}$ with a rapid transfusion set and $250 \mathrm{~mL} /$ min with a syringe) and efficiency (the possibility of collecting material for testing, administering drugs, fluids and blood products). Therefore, it is surprising that other aspects assessed in the diagnostic survey related to indications for IO access or access site recommendations for children under 6 years of age are known by the respondents to a very moderate degree (less than $45 \%$ of correct answers).

Hansen and co-authors were the first to conduct a large-scale Delphi study related to pediatric prehospital education, involving 737 experts in pediatric emergency care, including doctors, nurses and pre-hospital service providers. They identified intravenous and IO access as one of the top three technical and procedural skill needs [26]. Vincent-Lambert and co-authors in their research collected individual interviews with 12 purposefully selected paramedics from EMS in Johannesburg. Respondents, as one of the reasons for the rarely performed IO access in this city, reported the lack of appropriate equipment and the lack of adequate training [27]. In their report, Bielski and co-authors indicated the lack of appropriate equipment and training as the main factors limiting the use of IO access in the practice of EMS teams. A relatively small part of the study participants in the 12 months preceding the study underwent training in obtaining IO access, and even less practical training $-31.5 \%$ of paramedics from 168 , who completed the questionnaire [28]. Due to the limited amount of literature devoted to the assessment of the level of knowledge of students of medicine and emergency medicine, we will continue to explore this difficult topic, expanding our research with new questions and increasing the number of respondents. In our opinion, it is advisable to devote more attention to the subject of IO access and to increase the interest of students of medicine as well as emergency medicine in the subject of EMS, at least in such a basic scope. Consequently, it may have a positive and desired impact on the health care system in our country. Increasing students' awareness of procedures related to this issue will certainly allow for more efficient performance of activities related to IO access and increase the safety of both the patient and the people dealing with him. The authors draw attention to the large gaps in the education of students in terms of basic information of particular practical importance for the performance of the future professional practice. The article may be a starting point for considerations aimed at modifying the existing curricula. 


\section{CONCLUSIONS}

- The lack of sufficient knowledge and knowledge among students on the basics of IO access was demonstrated.

- The type of faculty and gender of the respondents did not have a significant influence on the knowledge of the procedures related to IO access.

- The respondents at the 5 th year of the medicine and at the third year of emergency medicine showed the greatest knowledge, as evidenced by the highest percentage of correct answers. It may be related to the presence of subjects during which topics related to the procedures and performance of IO access are carried out in these years of study.

- It is advisable to take measures aimed at improving the knowledge of future doctors and paramedics about the above-mentioned rescue activities, in order to improve the provision of help in emergency situations.

\section{REFERENCES}

1. Drinker CK, Drinker KR, Lund CC. The circulation of the mammalian bone marrow. Am J Physiol. 1922;62:1-92.

2. Janiszewska E. Wykonanie dojścia doszpikowego w stanach nagłego zagrożenia zdrowia lub życia. Prakt Zaw. 2014;10:13.

3. Czyż R, Zawłocki M, Czyż I. Wkłucie doszpikowe jako nowoczesna metoda zapewnienia dostępu do układu krążenia w warunkach medycyny ratunkowej. J Edu Health Sport. 2017;7(8):196-201.

4. Chronowski Sz, Gałuszka D, Nadolny K et al. Kiedy nie ma już wyboru - czyli o dostępie doszpikowym. Na Ratunek. 2019;5:8.

5. Szarpak $Ł$, Truszewski Z, Smereka J et al. A Randomized Cadaver Study Comparing First-Attempt Success Between Tibial and Humeral Intraosseous Insertions Using NIO Device by Paramedics: A Preliminary Investigation. Medicine (Baltimore). 2016;95(20): 55-61. doi: 10.1097/MD.0000000000003724.

6. Szarpak $€$, Czyżewski $Ł$, Wołoszczuk-Gębicka B et al. Comparison of NIO and EZ-IO intraosseous access devices in adult patients under resuscitation performed by paramedics: a randomized crossover manikin trial. Am J Emerg Med. 2016;34(6):1166-1167. doi: 10.1016/j.ajem.2016.03.017.

7. Hartholt KA, van Lieshout EM, Thies WC et al. Intraosseous devices: a randomized controlled trial comparing three intraosseous devices. Prehosp Emerg Care. 2010; 14(1): 6-13. doi: 10.3109/10903120903349861.

8. Leidel BA, Kirchhoff C, Braunstein V et al. Comparison of two intraosseous access devices in adult patients under resuscitation in the emergency department. Resuscitation. 2010;81(8):994-999. doi: 10.1016/j. resuscitation.2010.03.038.

9. Glaeser PW, Hellmich TR, Szewczuga D et al. Five-year experience in prehospital intraosseous infusion in children and adults. Ann Emerg Med. 1993;22:1119-1124.

10. Santos D, Carron PN, Yersin B et al. EZ-IO ${ }^{\circ}$ intraosseous device implementation in a pre-hospital emergency service: a prospective study and review of the literature. Resuscitation. 2013;84:440-445. doi: 10.1016/j. resuscitation.2012.11.006.

11. Olaussen A, Williams B. Intraosseous access in the prehospital setting: literature review. Prehosp Disaster Med. 2012;27:468-472. doi: 10.1017/S1049023X12001124.

12. Weiser G, Hoffmann Y, Galbraith R et al. Current advances in intraosseous infusion - a systematic review. Resuscitation. 2012;83:20-26. doi: 10.1016/j.resuscitation.2011.07.020.

13. Lee PM, Lee $C$, Rattner Pet al. Intraosseous versus central venous eatheter utilization and performance during inpatient medical emergencies. Crit Care Med. 2015;43:1233-1238. doi: 10.1097/CCM.0000000000000942.

14. Reades R, Studnek JR, Vandeventer S et al. Intraosseous versus intravenous vascular access during out-ofhospital cardiac arrest: a randomized controlled trial. Ann Emerg Med. 2011;58:509-516. doi: 10.1016/j. annemergmed.2011.07.020.

15. Leidel BA, Kirchhoff C, Bogner V et al. Comparison of intraosseous versus central venous vascular access in adults under resuscitation in the emergency department with inaccessible peripheral veins. Resuscitation. 2012;83:40-45. doi: 10.1016/j.resuscitation.2011.08.017.

16. Helm M, Haunstein B, Schlechtriemen T et al. EZ-IO® intraosseous device implementation in German Helicopter Emergency Medical Service. Resuscitation. 2015;88:43-47. doi: 10.1016/j. resuscitation.2014.12.015.

17. Wenzel V, Lindner KH, Augestein S et al. Intraosseous vasopressin improves coronary perfusion pressure rapidly during cardiopulmonary resuscitation in pigs. Crit Care Med. 1999; 27:1565-1569. 
18. Hoskins SL, do Nascimento Jr P, Lima RM et al. Pharmacokinetics of intraosseous and central venosus drug delivery during cardiopulmonary resuscitation. Resuscitation. 2012;83:107-112. doi: 10.1016/j. resuscitation.2011.07.041.

19. Burgert JM, Austin PN, Johnson A. An evidence-based reviev of epinephrine administered via the intraosseous route in animal models of cardial arrest. Mil Med. 2014;179:99-104. doi: 10.7205/ MILMED-D-13-00231.

20. Petitpas F, Guenezan J, Vendeuvre T et al. Use of intra-osseous access in adults: a systematic review. Crit Care. 2016;14(20):102.

21. Plancade D, Rüttimann M, Wagnon $G$ et al. The intraosseous infusion in adult. Ann Fr Anesth Reanim. 2013;32(5):347-354. doi: 10.1016/j.annfar.2013.02.024.

22. Lowther A. Intraosseous access and adults in the emergency department. Nurs Stand. 2011;25(48):35-38.

23. Gazin N, Auger H, Jabre P et al. Efficacy and safety of the EZ-IOTM intraosseous device: Out-of-hospital implementation of a management algorithm for difficult vascular access. Resuscitation. 2011;82(1):126129. doi: 10.1016/j.resuscitation.2010.09.008.

24. Yin R. Studium przypadku w badaniach naukowych. Projektowanie i metody. Kraków: Wydawnictwo Uniwersytetu Jagiellońskiego, 2015.

25. Szarpak L, Kurowski A, Adamczyk P et al. Are junior doctors trained to use to use intraosseous access?. Am J Emerg Med. 2016;34(1):107. doi: 10.1016/j.ajem.2015.10.020.

26. Hansen M, Meckler G, Dickinson C et al. Children's safety initiative: a national assessment of pediatric educational needs among emergency medical services providers. Prehosp Emerg Care. 2015;19(2): 28791. doi: 10.3109/10903127.2014.959223.

27. Carpenter VL. Factors affecting the frequency of vascular access via intraosseous cannulation performed by paramedics in Johannesburg. Vasc Access. 2014;15(6): 503-6. doi: 10.5301/jva.5000263.

28. Bielski K, Ładny J, Smereka J et al. Wiedza i postawy ratowników medycznych wobec stosowania wkłuć doszpikowych. Doniesienie wstępne. Ostry dyżur. 2016;1(9):1-4.

ORCID AND CONTRIBUTIONSHIP *

Tomasz Męcik-Kronenberg - 0000-0002-0618-8265 E,F

Aleksandra Joanna Kuć-0000-0002-3634-1347 A,B,,.,D,E,F

Katarzyna Krzyżak - 0000-0003-0982-5933 B,C,0,E,

Daria Małgorzata Kubik - 0000-0002-3588-5764 B,,C,,E

Klaudia Ewa Kościelecka - 0000-0002-6694-8182 B,C,0,E

\section{CONFLICT OF INTEREST}

Authors declare no conflict of interest.

\section{ADDRESS FOR CORRESPONDENCE}

Aleksandra Joanna Kuć

Wydział Nauk Medycznych w Zabrzu

Śląski Uniwersytet Medyczny w Katowicach

Pl. Traugutta 2, 41-800 Zabrze, Poland

tel.: 504188178

e-mail: aleksandra.kuc@interia.pl

RECEIVED

ACCEPTED

23.03.2020 


\title{
SODIUM-GLUCOSE COTRANSPORTER-2 INHIBITORS AS NEW STRATEGY OF CHRONIC HEART FAILURE MANAGEMENT
}

\author{
Andrii S. Herashchenko, Sergiy V. Fedorov \\ IVANO-FRANKIVSK NATIONAL MEDICAL UNIVERSITY, IVANO-FRANKIVSK, UKRAINE
}

\begin{abstract}
Introduction: Heart failure (HF) affects over 26 million people worldwide and is associated with high morbidity and mortality. Diabetes mellitus (DM) is a common cause of HF in current clinical practice. In recent years, the prevalence of DM has increased considerably, with an estimated 439 million adults worldwide projected to be affected by the year 2030. The aim: To was evaluate of modern trials in patients with diabetes and heart failure treated by Sodium-glucose cotransporter-2 inhibitors.

Materials and Methods: The database from PubMed for the last 10 years has been reviewed.

Conclusion: SGLT2i, namely Empagliflozin, has good results in their recovery from patients with HFrEF, but the results of their use in patients with HFpEF are currently questionable and need further study.
\end{abstract}

Key words

\section{INTRODUCTION}

Heart failure (HF) affects over 26 million people worldwide and is associated with high morbidity and mortality $[1,2]$. HF is an important cardiovascular disease due to its increasing prevalence and high mortality rate. HF is associated with a diverse range of complications, such as hospitalization, lethal arrhythmia, and death during the disease progression. In addition, HF can be the terminal condition of many cardiovascular diseases, including myocardial infarction (MI), valvular heart disease, and various cardiomyopathies [3]. Diabetes mellitus (DM) is a common cause of HF in current clinical practice. In recent years, the prevalence of DM has increased considerably, with an estimated 439 million adults worldwide projected to be affected by the year 2030 [4]. In 2007, the AHA and ADA issued a combined set of recommendations focused on the primary prevention of cardiovascular diseases (CVD) in diabetes mellitus [5]. CVD is the leading cause of morbidity and mortality in individuals with diabetes, and reducing CVD risk is a key treatment consideration [6].

\section{THE AIM}

The purpose of study was evaluate of modern trials in patients with diabetes and heart failure treated by Sodium-glucose cotransporter-2 inhibitors.

\section{MATERIALS AND METHODS}

The database from PubMed for the last 10 years has been reviewed.

\section{RESULTS AND DISCUSSION}

HF is a clinical syndrome characterized by distinct symptoms and signs, which is caused by structural and/or functional cardiac abnormalities [7-9]. Currently, the most common terminology for describing HF is based on left ventricular ejection fraction (LVEF). HF with normal LVEF $(\geq 50 \%)$ is defined as HF with preserved ejection fraction (HF$\mathrm{pEF})$, and HF with decreased LVEF $(<40 \%)$ as HF with reduced ejection fraction (HFrEF). HF patients with LVEF in the range of $40 \%$ to $49 \%$ are defined as HF with mid-range ejection fraction (HFmrEF). Although HFmrEF is now categorized as a separate entity, the epidemiology, pathophysiology, treatment, and prognosis of HFmrEF remain unclear [7].

HFpEF is often associated with other comorbidities including hypertension, corrected valvular disorders, atrial fibrillation, diabetes mellitus, obesity, sleep disorders breathing, lung disease, and renal disease [10]. Patients with HFpEF and with HFrEF often can be similar and give the nonspecific symptoms of heart failure - that is dyspnea on exertion, lower extremity edema, fatigue. Although HFpEF and HFrEF can often have the same clinical presentation, these are 2 separate entities [11], and therapies that improve outcomes in HFrEF have no benefit on outcomes in HFpEF. However, the lack of evidencebased treatment guidelines for $\mathrm{HFpEF}$, give a big possibility for further investigations. The principal biological processes that characterize $\mathrm{HFpEF}$ are systemic inflammation, epicardial adipose tissue accumulation, coronary microcirculatory rarefaction, 
myocardial fibrosis and vascular stiffness [12-16]; the resulting impairment of left ventricular and aortic distensibility (especially when accompanied by impaired glomerular function and sodium retention) causes increases in cardiac filling pressures and exertional dyspnoea despite the relative preservation of left ventricular ejection fraction (LVEF) [17]. The systemic inflammation in HFpEF can also cause changes in mitochondrial function and in the mass and composition of skeletal muscle [18] which can contribute to exercise intolerance in this disorder.

Symptomatic treatment of HFpEF is empiric and consists primarily of diuretics to reduce congestion, although the data to support even the use of diuretics are limited. Similarly, the data for rate control in patients with atrial fibrillation, which is highly prevalent in HFpEF, are limited [19]. There is strong indirect evidence that treatment of hypertension can be beneficial in HFpEF prevention, although the data are less clear for reducing morbidity or mortality in patients with known HFpEF [20]. In SPRINT trial [21], patients with aggressive blood pressure lowering had significantly fewer HF hospitalizations compared with those with less aggressive blood pressure control. In patients with established HFpEF, blood pressure lowering must be balanced by the consideration that HFpEF patients have steep end-systolic pressure-volume relationships with exaggerated drops in blood pressure and less enhancement in stroke volume in response to vasodilators, compared to patients with HFrEF [22]. Therapeutic interventions that can successfully ameliorate the derangement of biological pathways in HFpEF are still being explored. Mineralocorticoid receptor antagonists and neprilysin inhibitors have been shown to have favourable effects on cardiac structure and function and may potentially reduce the risk for serious cardiac events in these patients [23], but the evidence to date is inconclusive.

Sodium-glucose cotransporter-2 inhibitors (SGLT-2i) are the first class of glucose-lowering medications that have demonstrated a positive effect on risk reduction for HF hospitalisation [24] and cardiorenal benefits [25-27].

It has been proposed that one of the main mechanisms by which SGLT2 inhibitors exert their beneficial actions is via improvement of ventricular loading conditions, secondary to a reduction in preload primarily due to the diuretic and natriuretic effects [28, 29]. SGLT2 inhibition in the proximal tubule results in natriuresis and glucosuria, and the ensuing osmotic diuresis may be favourable, particularly in the heart of an individual with diabetes, which functions on a steep Frank-Starling curve. SGLT2 inhibitors are unique among the diuretics available clinically in that they modulate the function of the proximal tubule. The natriuretic response is also a stimulus for tubuloglomerular feedback, which in turn results in afferent arteriolar vasoconstriction with resultant reductions in intraglomerular hypertension. This process may explain the significant long-term renal preservation noted with SGLT2 inhibitors. Of note, angiotensin converting enzyme inhibitors and angiotensin receptor blockers cause efferent arteriolar vasodilatation and, when used in combination with SGLT2 inhibitors, will likely co-impact on intraglomerular pressure and may account for the initial drop in estimated glomerular filtration rate (eGFR) observed in patients, which is followed by a plateau over time [30]. Individuals with diabetes are known to have an increase in whole-body sodium content and, in recently completed translational studies in humans, the SGLT2 inhibitor dapagliflozin has been demonstrated to reduce tissue sodium content in people with type 2 diabetes [31].

Recent studies point to important differences between SGLT2 inhibitors and classical diuretics. For example, in a comparative study of dapagliflozin and hydrochlorothiazide (a classical diuretic), a reduction in plasma volume and increase in erythrocyte mass was noted with dapagliflozin but not with hydrochlorothiazide over a 12 week period of treatment [32]. In another study comparing dapagliflozin with the loop diuretic bumetanide, though both agents were associated with a reduction in sodium and interstitial fluid, dapagliflozin afforded these effects with little or no change in blood volume whereas bumetanide was associated with greater reductions in intravascular volume [33]. A differential effect in regulating interstitial fluid (vs intravascular volume) may be particularly important in patients with heart failure in whom, in many instances, intravascular contraction is present and often aggravated by diuresis. The ability to selectively reduce interstitial fluid may be a unique feature of SGLT2 inhibitors vs other diuretics and this may limit the reflex neurohumoral stimulation that occurs in response to intravascular volume contraction with traditional diuretics [30].

It has been postulated that SGLT2 inhibitors may improve and/or optimise cardiac energy metabolism and that by improving myocardial energetics and substrate efficiency these agents may improve cardiac efficiency and cardiac output [34, 35].

In the failing heart, the conservation of oxygen consumption is essential to maintain cardiac function. In terms of oxygen cost, the energy yield of betahydroxybutyrate $(\beta-\mathrm{HB})$ is comparable with that of 
glucose and pyruvate, and lower than palmitate [36]. In perfused working hearts, $\beta$-HB addition is readily taken up through a monocarboxylate transporter into the brain, heart and kidney [36], and preferentially oxidized in mitochondria. $\beta$-HB is exclusively produced in the liver, and the serum levels are reported to be increased in people with diabetes treated with SGLT2 inhibitors [37, 38]; a finding that might offer significant cardio-protection in the failing heart in type 2 diabetes patients with high coronary risk factors [39]. It is important to emphasise that we still have a lack definitive evidence linking myocardial energetics to the beneficial effects of SGLT2 inhibition.

Cardiac fibrosis is widely regarded as a common final pathway through which heart failure develops. This universally involves cardiac structural remodelling due to deposition of extracellular matrix proteins laid down by cardiac fibroblasts, resulting in impeded ventricular compliance and accelerated development of heart failure [40]. Recent experimental data in rat models of postmyocardial infarction demonstrate that dapagliflozin exhibits marked cardiac antifibrotic effects by suppressing collagen synthesis via increasing the activation of M2 macrophages and inhibiting myofibroblast differentiation [41].Other preliminary studies, using human cardiac fibroblasts, have demonstrated that empagliflozin significantly attenuates TGF- $\beta 1$ induced fibroblast activation and reduces cellmediated extracellular matrix remodelling as measured by the collagen fibre alignment index [38]. In the same series of studies, the authors demonstrated that empagliflozin suppressed expression of key pro-fibrotic markers, including typeI collagen, $\alpha$-smooth muscle actin, connective tissue growth factor and matrix metalloproteinase 2 . Therefore, an emerging postulate is that SGLT2 inhibition, independent of hyperglycaemia, may have direct and favourable effects on cardiac fibroblast phenotype and function, one of the most important factors of heart failure.

EMPA-REG OUTCOME was the first cardiovascular outcome trial (CVOT) of an SGLT2i to publish final data [26]. Briefly, this was a multicenter, randomized, double-blind, placebo-controlled trial to assess the effect on $\mathrm{CV}$ events of once-daily empagliflozin (10 $\mathrm{mg}$ or $25 \mathrm{mg}$ ) versus placebo administered in addition to standard care in adults with T2DM and established CVD [26].

The reduction in hospitalization for heart failure with empagliflozin was an unexpected result during EMPA-REG OUTCOME, and may suggest that this agent could affect ventricular function in addition to its diuretic effects. Subsequent data analysis showed a consistent benefit of empagliflozin therapy in those with and without heart failure at baseline [42]. As with the observed reduction in $\mathrm{CV}$ death, the effect of empagliflozin on heart failure hospitalization occurred very early in the trial. Again, this is suggestive of a non-atherosclerotic driven effect (42). Potential contributory factors include reduced cardiac preload and afterload, reduced plasma volume, osmotic diuresis, reduced arterial stiffness, and decreased double product or rate pressure product (heart rate multiplied by systolic blood pressure [BP]), as well as reductions in body weight, BP, and hyperglycemia [42] Other mechanisms may also have a role, although supporting data are limited at present [43].

The EMPEROR-Preserved Trial is specifically designed to determine if empagliflozin can treat patients with established HFpEF, whether or not they have diabetes. Importantly, the EMPEROR-Preserved Trial plans to evaluate adiverse array of circulating measures of adiposity and inflammation, as well as biomarkers of cardiac and renal injury. It is therefore well positioned to identify the mechanisms by which empagliflozin is beneficial if it achieves success in its planned endpoints [44].

In the first interim analysis of the EMPRISE trial, Patorno et al. have shown that initiation of empagliflozin is superior to sitagliptin in reducing risk of HHF in a real-world setting. These results strengthen the findings of the EMPA-REG OUTCOME trial by comparing empagliflozin to a therapeutic alternative rather than to placebo and including patients with and without CVD [45].

The EMPA-HEART CardioLink-6 trial demonstrated that compared with placebo, the addition of empagliflozin to standard antihyperglycemic treatment in people with type 2 diabetes and CAD was associated with a significant reduction in LVMi as measured by cMRI. The use of empagliflozin was also associated with a significant lowering of ambulatory systolic blood pressure with no impact on the circulating levels of NT-proBNP. Proposed mechanisms to explain the reduction of heart failure outcomes of SGLT2 inhibitors include natriuresis, osmotic diuresis, a reduction in preload and afterload, inhibition of the cardiac sodium-hydrogen exchanger, and improved myocardial bioenergetics [28, 30, 46, 47]

However, whether these mediators alter cardiac structure and function remains an important and unanswered clinical question. Although experimental data and clinical case reports have suggested that SGLT2 inhibitors may improve cardiac structure and function $[28,29]$ this is the first trial to provide randomized clinical data in humans demonstrating that the SGLT2 inhibitor empagliflozin promotes LV mass 
regression. Given that LVM regression is an important and causal determinant of cardiovascular events and mortality, these data provide potential translational insights into the biology of SGLT2 inhibitors and their cardioprotective outcome benefits [48].

\section{CONCLUSION}

SGLT2i, namely Empagliflozin, has good results in their recovery from patients with HFrEF, but the results of their use in patients with HFpEF are currently questionable and need further study.

\section{REFERENCES}

1. Ambrosy AP, Fonarow GC, Butler J, et al. The global health and economic burden of hospitalizations for heart failure: lessons learned from hospitalized heart failure registries. J Am Coll Cardiol 2014;63:11231133.

2. Owan TE, Hodge DO, Herges RM, Jacobsen SJ, Roger VL, Redfield MM. Trends in prevalence and outcome of heart failure with preserved ejection fraction. N Engl J Med 2006;355:251-259.

3. Choi H, Park M, Youn J. Update on heart failure management and future directions. Korean J Int Med. 2019;34(1):11-43.

4. Shaw JE, Sicree RA, Zimmet PZ. Global estimates of the prevalence of diabetes for 2010 and 2030. Diabetes Res Clin Pract. 2010;87:4-14.

5. Fox C, Golden S, Anderson C, et al. Update on Prevention of Cardiovascular Disease in Adults With Type 2 Diabetes Mellitus in Light of Recent Evidence: A Scientific Statement From the American Heart Association and the American Diabetes Association. Diabetes Care. 2015;38(9):1777-1803.

6. Cardiovascular Disease and Risk Management. Diabetes Care. 2016;40(Suppl 1):S75-S87.

7. Ponikowski P, Voors AA, Anker SD, et al. 2016 ESC guidelines for the diagnosis and treatment of acute and chronic heart failure: the task force for the diagnosis and treatment of acute and chronic heart failure of the European Society of Cardiology (ESC) developed with the special contribution of the Heart Failure Association (HFA) of the ESC. Eur Heart J. 2016;37:2129-2200.

8. Kim MS, Lee JH, Kim EJ, et al. Korean guidelines for diagnosis and management of chronic heart failure. Korean Circ J. 2017;47:555-643.

9. Youn JC, Han S, Ryu KH. Temporal trends of hospitalized patients with heart failure in Korea. Korean Circ J. 2017;47:16-24.

10. Gladden JD, Linke WA, Readfild MM. Heart failure with preserved ejection fraction. Pflugers Arch. 2014;466(6):1037-1053.

11. Borlaug BA,Paulus WJ. Heart failure with preserved ejection fraction: pathophysiology? Diagnosis, and treatment. Eur Heart J.2011;32(6):670-679.

12. Tromp J, Khan MA, Klip IT, et al. Biomarker profiles in heart failure patients with preserved and reduced ejection fraction. J Am Heart Assoc 2017;6:e003989.

13. Paulus W, Dal Canto E. Distinct Myocardial Targets for Diabetes Therapy in Heart Failure With Preserved or Reduced Ejection Fraction. JACC: Heart Failure. 2018;6(1):1-7.

14. Packer M. The epicardial adipose inflammatory triad: coronary atherosclerosis, atrial fibrillation, and heart failure with a preserved ejection fraction. Eur J Heart Fail 2018;20:1567-1569.

15. Mohammed SF, Hussain S, Mirzoyev SA, Edwards WD, Maleszewski JJ, Redfield MM. Coronary microvascular rarefaction and myocardial fibrosis in heart failure with preserved ejection fraction. Circulation 2015;131:550-559.

16. van Woerden G, Gorter TM, Westenbrink BD, Willems TP, van Veldhuisen DJ, Rienstra M. Epicardial fat in heart failure patients with mid-range and preserved ejection fraction. Eur J Heart Fail 2018;20:1559-1566.

17. Abudiab MM, Redfield MM, Melenovsky V, Olson TP, Kass DA, Johnson BD, Borlaug BA.Cardiac output response to exercise in relation to metabolic demand in heart failure with preserved ejection fraction. EurJHeartFail 2013;15:776-785.

18. Kitzman DW, Haykowsky MJ, Tomczak CR. Making the case for skeletal muscle myopathy and its contribution to exercise intolerance in heart failure with preserved ejection fraction. Circ Heart Fail 2017;10:e04281.

19. Kotecha D, Lam CS, Van Veldhuisen DJ, Van Gelder IC, Voors AA, Rienstra M. Heart failure with preserved ejection fraction and atrial fibrillation: vicious twins. J Am Coll Cardiol 2016;68:2217-2228.

20. Lam C, Voors A, de Boer R, Solomon S, van Veldhuisen D. Heart failure with preserved ejection fraction: from mechanisms to therapies. European Heart Journal. 2018;39(30):2780-2792. 
21. Wright JT Jr, Williamson JD, Whelton PK, et al. A randomized trial of intensive versus standard bloodpressure control. N Engl J Med 2015;373:2103-2116

22. Schwartzenberg S, Redfield MM, From AM, Sorajja P, Nishimura RA, Borlaug BA. Effects of vasodilation in heart failure with preserved or reduced ejection fraction implications of distinct pathophysiologies on response to therapy. J Am Coll Cardiol 2012;59:442-451

23. Pfeffer MA, Claggett B, Assmann SF, et al Regional variation in patients and outcomes in the Treatment of Preserved Cardiac Function in Heart Failure with an Aldosterone Antagonist (TOPCAT) trial. Circulation 2015;131:34-42.

24. Seferović P, Coats A, Ponikowski P, et al. European Society of Cardiology/Heart Failure Association position paper on the role and safety of new glucose-lowering drugs in patients with heart failure. Eur J Heart Fail. 2020;22(2):196-213.

25. Neal B, Perkovic V, Mahaffey KW, et al. Canagliflozin and cardiovascular and renal events in type 2 diabetes. N Engl J Med 2017;377:644-657

26. Zinman B, Wanner C, Lachin JM, et al Empagliflozin, cardiovascular outcomes, and mortality in type 2 diabetes. N Engl J Med 2015;373:2117-2128.

27. Verma S, Mazer CD, Fitchett D, et al (2018) Empagliflozin reduces cardiovascular Zinman B, Wanner C, Lachin JM, Fitchett D, Bluhmki E, Hantel S, Mattheus M, Devins T, Johansen OE, Woerle HJ, Broedl UC, Inzucchi SE, EMPA-REG OUTCOME Investigators.N Engl J Med. 2015 Nov 26; 373(22):2117-28.

28. Verma S, McMurrayJJV, CherneyDZI. The metabolodiuretic promise of sodium-dependent glucose cotransporter 2 inhibition: the search for the sweet spot in heart failure. JAMA Cardiol. 2017;2:939-940

29. Sattar N, McLarenJ, KristensenSL, Preiss D, McMurray JJ. SGLT2 inhibition and cardiovascular events: why did EMPA-REG Outcomes surprise and what were the likely mechanisms? Diabetologia 2016;59:1333-1339.

30. Verma S, McMurray J. SGLT2 inhibitors and mechanisms of cardiovascular benefit: a state-of-the-art review. Diabetologia. 2018;61(10):2108-2117.

31. Karg MV, Bosch A, Kannenkeril D, et al. SGLT-2-inhibition with dapagliflozin reduces tissue sodium content: a randomised controlled trial. Cardiovasc Diabetol 2018;17:5.

32. Lambers Heerspink H, de Zeeuw D, Wie L, Leslie B, List J. Dapagliflozin a glucose-regulating drug with diuretic properties in subjects with type 2 diabetes. Diabetes, Obesity and Metabolism. 2013;15(9):853-862.

33. Hallow KM, Helmlinger G, Greasley PJ, McMurray JJV, Boulton DW. Why do SGLT2 inhibitors reduce heart failure hospitalization? A differential volume regulation hypothesis. Diabetes Obes Metab 2018;20:479-487.

34. Ferrannini E, Mark M, Mayoux E CV protection in the EMPA-REG OUTCOME Trial: a "Thrifty Substrate" hypothesis. Diabetes Care 2016;39:1108-1114.

35. Lopaschuk GD, Verma S. Empagliflozin's fuel hypothesis: not so soon. Cell Metab 2016;24:200-20

36. Polidori D, Iijima H, Goda M, Maruyama N, Inagaki N, Crawford P. Intra- and inter-subject variability for increases in serum ketone bodies in patients with type 2 diabetes treated with the sodium glucose cotransporter 2 inhibitor canagliflozin. Diabetes, Obesity and Metabolism. 2018;20(5):1321-1326.

37. Taylor SI, Blau JE, Rother KI. SGLT2 Inhibitors. Predispose to Ketoacidosis. J Clin Endocrinol Metab 2015;100:2849-2852.

38. Kaku K, Watada H, Iwamoto Y, et al. Efficacy and safety of monotherapy with the novel sodium/glucose cotransporter-2 inhibitor tofogliflozin in Japanese patients with type 2 diabetes mellitus: a combined Phase 2 and 3 randomized, placebo-controlled, double-blind, parallel-group comparative study. Cardiovasc Diabetol. 2014;13(1):65.

39. Ferrannini E, Baldi S, Frascerra S, et al Shift to fatty substrate utilization in response to sodium-glucose cotransporter 2 inhibition in subjects without diabetes and patients with type 2 diabetes. Diabetes 2016;65:1190-1195.

40. Andenæs K, Lunde I, Mohammadzadeh N, et al. The extracellular matrix proteoglycan fibromodulin is upregulated in clinical and experimental heart failure and affects cardiac remodeling. PLOS ONE. 2018;13(7):e0201422.

41. Lee TM, Chang NC, Lin SZ Dapagliflozin, a selective SGLT2 inhibitor, attenuated cardiac fibrosisbyregulating the macrophage polarization via STAT3 signaling in infarcted rat hearts. Free Radic Biol Med 2017;104:298-10. 
42. Fitchett D, Zinman B, Wanner C, et al. EMPA-REG OUTCOME® trial investigators. Eur Heart J. 2016;37(19):1526-34.

43. Santos Cavaiola T, Pettus J. Cardiovascular effects of sodium glucose cotransporter 2 inhibitors. Diabet Metabol Syndr Obesity: Targ Ther. 2018;11:133-148.

44. Anker S, Butler J, Filippatos G, et al. Evaluation of the effects of sodium-glucose co-transporter 2 inhibition with empagliflozin on morbidity and mortality in patients with chronic heart failure and a preserved ejection fraction: rationale for and design of the EMPEROR-Preserved Trial. Eur J Heart Fail. 2019;21(10):1279-1287.

45. A Promising EMPRISE: Empagliflozin and Heart Failure Outcomes in Type 2 Diabetes Patients - American College of Cardiology [Internet]. American College of Cardiology. 2020 [cited 23 May 2020]. Available from: https://www.acc.org/latest-in-cardiology/articles/2019/09/17/15/02/a-promising-emprise

46. Connelly KA, Bhatt DL, Verma S. Can We DECLARE a Victory against Cardio-Renal Disease in Diabetes? Cell Metab. 2018;28:813-815. 22.

47. Lopaschuk GD, Verma S. Empagliflozin's Fuel Hypothesis: Not so Soon. Cell Metab. 2016;24:200-202.

48. Verma S, Mazer C, Yan A, et al. Effect of Empagliflozin on Left Ventricular Mass in Patients With Type 2 Diabetes Mellitus and Coronary Artery Disease. Circulation. 2019;140(21):1693-1702.

ORCID AND CONTRIBUTIONSHIP*

Andrii S. Herashchenko - 0000-0003-4090-7320 A,B,C,0,E,F

Sergiy V. Fedorov - 0000-0002-2202-4279 A,B,C,D,E,F,

\section{CONFLICT OF INTEREST}

Authors declare no conflict of interest.

\section{ADDRESS FOR CORRESPONDENCE}

Sergiy V. Fedorov

Ivano-Frankivsk National Medical University IvanoFrankivsk,

2 Halytska Str., Ivano-Frankivsk, 76018, Ukraine e-mail:serfed@i.ua 


\title{
TRIAGE AND EMERGENCY MEDICAL MANAGEMENT OF THE ACUTE RADIATION SYNDROME
}

\author{
Arkadiusz Trzos ${ }^{1,2}$, Wiktoria Kudła ${ }^{3}$, Karol Łyziński ${ }^{1,4}$ \\ 1 DEPARTMENT OF DISASTER MEDICINE AND EMERGENCY, CARE CHAIR OF ANAESTHESIOLOGY AND INTENSIVE CARE, \\ FACULTY OF MEDICINE JAGIELLONIAN UNIVERSITY MEDICAL COLLEGE, CRACOW, POLAND \\ 2 ATMED MEDICINE AND EDUCATION, CRACOW, POLAND \\ 3 ACADEMIC CIRCLE OF EXTREME MEDICINE AND DISASTER MEDICINE AT THE DEPARTMENT OF DISASTER MEDICINE \\ AND EMERGENCY CARE, CHAIR OF ANAESTHESIOLOGY AND INTENSIVE THERAPY, FACULTY OF MEDICINE, \\ JAGIELLONIAN UNIVERSITY MEDICAL COLLEGE, CRACOW, POLAND \\ 4 EMERGENCY MEDICAL SERVICES IN CRACOW, CRACOW, POLAND
}

\section{Abstract}

Introduction: Medical personnel of the state Emergency Medical Services (EMS) will be the first element involved in providing assistance to victims of radiation incidents. Triage, initial diagnosis and further patient medical management will depend on their actions. In many radiation incidents, initial radiation triage and early diagnostics will be carried out in the emergency department (ED) or trauma center (TC). Extended triage, diagnosis of ARS and proper treatment will be continued in specialist centers.

The aim: To present a model of patient medical management including initial triage and early diagnosis of ARS that can be carried out at the ED and TC.

Material and methods: The initial medical procedures prepared by expert groups were presented. The choice of procedures was made in terms of the possibility of their application by the EMS teams in Poland. Particular attention was paid to the method of initial triage, based on the clinical condition and laboratory diagnostics.

Results: Based on the material collected, the path of the initial medical procedure was presented. Variants of the radiation triage, interpretation of clinical parameters and results of laboratory tests are presented. The methods of initial treatment and the method of qualification for specialist treatment, and new methods of treating patients were also described.

Conclusions: An adequate evaluation of radiation incidents, determining the absorbed dose of ionising radiation and ARS, as well as initial triage seem to be crucial skills of the EMS workers.

\section{INTRODUCTION}

A radiation incident is any event occurring in Poland and abroad involving the use of nuclear materials, ionising radiation sources, radioactive waste products or any other radioactive substances which result in or have the potential to result in a radiation emergency in which ionising radiation threshold doses, specified in the applicable regulations, might have been exceeded, and hence certain emergency medical procedures may be required to maintain safety of workers and the general public [1]. Emergency procedures in the event of a radiation emergency are subject to the regulation of 18 January 2005 on emergency procedure plans in a radiological emergency [2].

Health effects of absorbed radiation may be the result of external exposure to radiation that may be combined with external contamination with radioactive substances; or internal contamination resulting from absorption of radioactive isotopes through inha- lation of radioactive dust, swallowing contaminated food products or water or through skin involving direct handling of contaminated material (skin contamination). Those three modes of exposure to radiation may occur together and may be combined with other traumas e.g. thermal, mechanical from a blow. A type of exposure to ionising radiation may determine emergency medical management and priorities of procedures. In the event of radioactive contamination or any assumption that such contamination might have occurred, decontamination procedures shall be started to prevent further radiation [3]. The absorbed dose greater than $1 \mathrm{~Gy}$ in case of whole-body or high-dose significant partial-body exposure to radiation results in the acute radiation syndrome (ARS) [4]. In case of subthreshold doses, changes in shorttermed peripheral blood values may be noted. Doses greater than 10 Gy are considered to be mainly lethal [5]. In the event of exposure to doses larger than 10 
Gy, the bone marrow failure is of minor importance for survival in patients as their survival is dependant on the damages to organs other than the bone marrow such as the lungs, gastrointestinal tract, and cutis since these patients tend to suffer fatal multi-organ failure (MOF) even though the bone marrow aplasia has been successfully managed. Recent data suggests that the average lethal dose of radiation to the whole body that will kill $50 \%$ of the exposed population within 60 days (LD50/60) ranges between 3.25 Gy and 4 Gy for patients without supportive treatment and 6-7 Gy for patients treated with antibiotics and transfusion [7]. A concentrated radiation dose may lead to cutaneous radiation syndrome (CRS) without the probability of developing MOF. Beta radiation and low-energy X-ray do not penetrate deep in tissue and induce only cutaneous injuries without any damage to the internal organs $[8,9]$.

The management of radiation emergencies used so far has been mainly focused on providing medical treatment to individual casualties or a minor group of casualties in places where radiation sources were used, thus the radiation emergency was expected. Moreover, adopted medical procedures have responded only to radiation-induced injuries excluding the impact of other traumas, mostly mechanical ones (post-explosion injuries). The end of the cold war has not limited the radiation threat. In recent years the total amount of scattered radiation material has increased globally. The situation is caused by temporary loss of control over nuclear materials and their uncontrolled distribution, and partly due to an increased ability and apparent readiness of terrorists and criminal groups to use nuclear materials for their own purposes. The use of radioactive materials in "dirty bombs" or constructing and detonating an improvised nuclear device have become common terrorist attack scenarios. Computer simulations of nuclear attacks allow to estimate the number of civil casualties $[10,11]$. For instance, it is estimated that more than 500000 people would be in a damage zone within 2 hours from a $10 \mathrm{kT}$ nuclear detonation in Los Angeles (California, USA) [12]. The prospects of massive human losses are changing medical responders' approach regarding the management of rescue actions performed during radiation emergencies. Therefore, the experience of military medicine is more often taken into consideration.

In case of radiation emergency the national EMS teams are to be involved in the management of rescue actions on both pre-hospital and early hospital stages (emergency rooms, trauma centres). Consequently, the EMS shall take on the responsibility for relevant diagnosis and initial care provided to the injured in the radiation incident. Further diagnosis and specialist care are provided in specialist care centres. The authors of this paper, being aware of the complex nature of medical care management in case of radiation incidents, have focused on triage, diagnostics and procedures that are employed during the rescue actions performed by EMS teams to the patients exposed to large doses of radiation.

\section{TRIAGE}

Initial responses of rescue teams in terms of radiation incidents involve assessing medical condition of casualties (triage). Furthermore, certain patients will receive priority intervention at subsequent levels of care. Initial triage based on the ABCD approach enables to decide whether injuries are life-threatening and require an immediate medical intervention. $\mathrm{Pa}$ tients with potentially life-threatening injuries must be primarily treated, and then decontaminated [13]. Once the vital functions are stable, EMS may proceed to triage and radiation diagnostics. Radiation triage guidelines differ from the model commonly used by the EMS teams on a daily basis. Moreover, depending on the scale of an incident, and the number of casualties and the efficiency of emergency services in particular, the interpretation of the results of triage scores may be altered. Radiation triage includes assessing, monitoring symptoms of each ARS stage (prodromal, latent, manifest illness and recovery or death) and calculating the absorbed dose. Samples of tissue are drawn and biometric tests are carried out in order to determine the absorbed dose. Combined-injury casualties (combined traumas) with both radiation and mechanical traumas need to undergo trauma and radiation triage, and thus relevant modification of the results may be required (Table 1).

For the purposes of triage and early diagnostics, methods of clinical assessment and laboratory tests may be employed simultaneously.

\section{CLINICAL EVALUATION}

Initial radiation triage of the patient especially in terms of mass incidents may be based on the evaluation of prodromal stage. The onset of symptoms after the exposure, the intensity and severity of prodromal symptoms shall allow to estimate the absorbed dose. Table 2 presents parameters and interpretation of results in this particular evaluation method in detail.

The onset of radiation-induced vomiting and its severity is the most indicative parameter for the assessment of a patient's condition [14]. Other parameters are of lesser importance to assess the severity of 
the radiation injuries. Body temperature above $37 \mathrm{oC}$ within 5 hours after the exposure to radiation indicates the dose of $\geq 2,5$ Gy [15]. The occurrence of early erythema within 6 hours after the exposure may precede the development of the cutaneous radiation syndrome (CRS) [16]. A different model of clinical evaluation is the scoring triage system METREPOL to assess radiation damage to vital organ systems of patients suffering from the ARS: neurovascular $(\mathrm{N})$, hematopoietic $(\mathrm{H})$, cutaneous $(\mathrm{C})$ and gastrointestinal $(G)$. The evaluation of a damaged organ includes symptoms typical for certain damages. Scoring of the patients done by organs reflects damages to organ systems and indicates the most affected ones and potential risks they carry and the best choice for treatment of individuals (Table 3). Each symptom is scored from 1 to 4 according to its degree of severity. A score of 1 implies mild damages while 4 fatal ones. A score of 0 in this protocol means there are no symptoms observed. Having determined (i - degree of severity) the organ specific grading $(\mathrm{Ni}, \mathrm{Hi}, \mathrm{Ci}$, $\mathrm{Gi})$, the response category is established $(\mathrm{RC}=$ ? $\mathrm{xd})$ and measured in days (xd) after exposure. The above classification enables the analysis of changes observed in an individual patient and allows to draw a comparison of medical conditions between patients (Fig. 1) [17].

The application of grading codes improves communication between specialists, facilitates national and international communication and interdisciplinary expertise. Coding improves the management of treatment and accurate allocation of the injured.

\section{LABORATORY DIAGNOSTICS}

The contemporary ARS diagnostics consists of both observing a patient and specialised diagnostic testing [18]. All persons involved in a radiation incident that have been exposed to ionising radiation should be examined with the use of a biodosimetry during the first 48 hours after the exposure [19]. In the first place a complete blood count (CBC) should be carried out. A CBC should be repeated every 4 hours during the first 8 hours following the exposure and every 6 hours for the next 40 - 48 hours. A CBC analysis is done with special attention to lymphocyte counts which is the easiest and fastest laboratory diagnostic tool to assess the absorbed dose [18]. Lymphocyte depletion is to be observed within 6-24 hours following the exposure [20]. A CBC analysis done after 2 weeks following the exposure has shown leukopenia, lymphopenia and thrombocytopenia. Thereafter, anaemia is observed as well [31]. Lymphocyte depletion rate may suggest the irradiation symptoms in patients who are unaware of having been exposed to ionising radiation. Another solution to be used while denoting the exposure is checking the levels of serum amylase. It has been indicated that any radiation dose greater than 0,5 Gy increases the levels of amylase in blood [21]. Although the level of amylase may increase in other clinical situations, it is worth mentioning that the increase in amylase especially in its salivary fraction may suggest the exposure to radiation [22].

The gold standard for diagnosing ARS is dosimetry of chromosomal aberration in circulating blood lymphocytes. Biological dosimetry enables to calculate the absorbed dose based on the analysis of the radiation damages observed in irradiated cells i.e. the effects of radiation. 6 dicentric chromosomes in 1000 cells have been observed after radiation of 0.1 Gy. The dicentric chromosome assay (DCA) is employed in case of the exposure with doses of range of 0.1 to 5-6 Gy [23]. The cell division is blocked above this range; thus, this method is found useless for higher doses. Another example of mutations at a molecular level are micronuclei. Micronuclei are not as sensitive to radiation as dicentrics. The detection level is $0.3 \mathrm{~Gy}$. The frequency of the occurrence of micronuclei is directly proportional to the radiation dose. Moreover, due to radiation, chromosomal translocations are present. 4 - 12 spontaneous translocations in 1000 cells have been detected with a dose of range 0.5 - $5 \mathrm{~Gy}$. It is possible to observe due to a fluorescent in situ hybridization (FISH) technique, which uses molecular probes to visualise specific DNA sequences. An entire chromosome or fragments of chromatin near centromeres of individual chromosomes have been analysed. With doses greater than 5 - 6 Gy it is crucial to detect premature chromosome condensation (PCC). The evaluation of dicentric chromosomes is proved unreliable with higher doses of radiation while PCC is dose-independent so there are no restrictions [24].

\section{TREATMENT MANAGEMENT}

Appropriate medical interventions following the radiation exposure at both pre-hospital and early hospital stages (emergency rooms, trauma centres) involve interviewing the patient, physical examination, running additional tests, and based on their results estimating the absorbed dose and introducing symptomatic treatment [25]. Treatment in the prodromal phase focuses on administering antiemetics, antidiarrheals, analgesics, blood transfusion or blood products [26,27]. 5HT-3 receptor antagonists are most effective for vomiting. According to the Radiation 
Emergency Assistance Center/Training Site ondansetron, granisetron can be utilized for the treatment and only alosetron is not recommended for gastrointestinal syndrome because it is associated with colonic ischaemia [28]. Anticholinergics or loperamid can be used to treat diarrhoea of patients exposed to radiation [29]. Patients suffering from headaches being the result of radiation should receive widely available painkillers. Acetylsalicylic acid must be given with caution due to a greater risk of bleeding [30]. Any blood products that are given to a patient must be leukoreduced and irradiated with a dose of 25 Gy to prevent transfusion-associated graft-versus-host reaction [31,32]. It is advised to treat with granulocyte macrophage colony-stimulating factor (GM-CSF), granulocyte colony-stimulating factor (G-CSF), and the pegylated form of G-CSF when radiation doses are from 5 to $10 \mathrm{~Gy}$. Patients should be treated with CSFs in the first 24 hours to become effective [13]. Patients with ARS are treated with cytokines such as filgrastim (G-CSF), sargramostim(GM-CSF), pegfilgrastim (pegG-CSFC) [33]. Cytokine therapy should be continued for 2-3 weeks following the exposure or until an absolute neutrophil count equals $>1000 \mu \mathrm{L}$. Interleukin (IL)-12 is also used besides GM-CSF. IL12 stimulates megakaryocyte growth and unlike cytokines improves patients' survival after irradiation [34]. In irradiated patients with doses greater than 10 Gy administering cytokine therapy is doubtful due to possible lack of stem-progenitor cells. Those patients require a bone marrow stem cell transplantation [4]. New solutions are being constantly searched for to treat ARS even more effectively. Lots of tests have been carried out on animals to get a new perspective on treating ARS. Entolimod/CBLB52 acts as an agonist of toll-like receptor 5 (TLR5). Tests on animal models proved entomolid to lead to a significant improvement in animal survival and neutropenia after exposure with lethal doses of radiation [35]. AEOL 10150 (metalloporphyrin mimetic) acts as an antioxidant and is administered to the patients with acute, radiation-induced lungs injury. The results of one pilot study have indicated that treatment with AEOL 1050 results in reduced clinical, radiographic, anatomic, and molecular evidence of radiation-induced lung injury [36]. 5-androstenediol (AED) is administered with doses of 4-6 Gy and is observed to improve a CBC especially platelets so it becomes useful to treat acute hematopoietic radiation syndrome [37]. When salivary glands get irradiated causing dry mouth and reduced saliva production, amifostine is used [38]. An increased risk of bleeding and blood loss in irradiated individuals require blood platelets transfusion, which is the only available medical intervention to treat thrombocytopenia. Several factors are considered such as interleukin-11, thrombopoietin TPO, romiplostim (a peptide TPO mimetic that binds and activates the TPO-receptor) and eltrombopag (a non-peptide that binds to a transmembrane site on the TPO-receptor) [33]. It is recommended to have platelets maintained at $\geq 20000 / \mathrm{L}$ in irradiated individuals [39].

\section{SUPPORTIVE THERAPY}

In the event of radiation incidents, supportive care should include the administration of antimicrobial agents. The risk of infections is high due to a low number of lymphocytes and neutrophils in the blood and skin barrier and mucous membrane disruptions, which works as a physical barrier to protect from germs. Since immune functions may be impaired, a sanitary regime is highly required in order to prevent transmission of pathogens. The intensity of infections in patients with ARS depends on the virulence of infectious agents, humoral and cell-type responses and an effective phagocytic function [27]. The use of antimicrobial agents depends on the number of neutrophils in blood. If the patient's neutrophil count is $>500 / \mu 1$, then therapy with fluoroquinolones (e.g. levofloxacin) should be chosen. If the patient's neutrophil count is $<500 / \mu 1$, broad-spectrum intravenous antibiotic therapy should be considered. The scheme of intravenous antibiotic therapy may be as follows: I single-drug therapy: imipenem/cilastatin/meropenem/piperacillin/tazobactam/cefepime / ceftazidime

II 2-drug therapy: aminoglycoside/cilastatin + penicillin or aminoglycoside + cephalosporin

III therapy with vancomycin is limited to specific indications for intravenous monotherapy or combination therapy [40].

Antibiotic therapy should be administered immediately to patients with neutropenic fever. Prominent causes of infections are Gram-positive bacteria (incl. methicillin-resistant Staphylococcus and vancomycin-resistant Enterococcus) and Gram-negative bacteria (incl. Pseudomonas aeruginosa, Escherichia coli, and Klebsiella species) [40].

Immunosuppressed patients exposed to radiation are more susceptible to viral and fungal infections. Acyclovir for viral infections and fluconazole for fungal ones are advised to be administered. Cytomegalovirus and opportunistic Pneumocystis Jirovecii are considered to be important pathogens whose reactivation may be the result of progressive radiation-induced immunosuppression [37]. 


\section{DISCUSSION}

Radiation incidents vary depending on the nature of the event and may pose different threats. Patients at the Emergency Department might have been exposed to radiation a long time before and may have no knowledge of high-dose exposure. Patients may bring radioactive materials into hospital when the substance is deposited on their body surface or clothing unknowingly. EMS teams may be sent to a patient who is in a contaminated environment so it is crucial to take radiation risks into consideration when assessing safety of performed medical interventions. Triage and medical care management happens to be complex. The analysis of radiation incidents showed that the level of irradiation of casualties injured in the same incident may vary depending on the absorbed dose and tissue volume exposed to radiation. Radiation exposures can involve a small part of the body (e.g. arms), larger parts or the whole body. Furthermore, body positioning affects the absorbed dose. Certain exposure to the source of radiation may damage or shield sensitive organs and biological effects of the same dose may be different. The radiation dose may be delivered over an extended period of time (repeated exposures) or as a single exposure to a high dose of radiation. The fact which body part is affected by radiation is of greater importance than an overall dose of exposure. This variability makes standardization of triage process, diagnosing and implementing medical treatment extremely difficult. For that reason the management of medical responses in radiation events is complex and multi-layered. Once an early/initial diagnostic process is performed at Emergency Rooms, patients should be distributed appropriately for different departments depending on the scale of damages to their organs and available resources such as well-trained personnel, equipment and medication. Patients who are likely to develop MOF (RC>3) should be admitted to the intensive care unit; patients with severe and extensive radiation skin lesions should be admitted to the burn unit and all remaining patients to the haematological cell therapy unit. Triage and proper allocation enable an effective use of available resources and improve the efficacy of medical treatment provided.

It is crucial for the medical care management to decide whether patients have residual hematopoiesis, which is common after the radiation incidents since some parts of the bone marrow tend to be underexposed or protected from accidental radiation. The residual hematopoiesis significantly influences a decision-making process of medical teams as hematopoietic stem cell (HSC) transplantation, despite the absorbed dose being high, may be unnecessary. HSC transplantation should not be performed on radiation incident casualties who have the potential of endogenous hematopoietic recovery. Radiation-induced casualties are not advised to have hematopoietic stem cells transplanted due to patients' potential of endogenous hematopoietic recovery. Therefore, emergency HSC transplantation is not necessary in every accidental wholebody irradiation. However, if severe aplasia persists in spite of cytokine treatment for more than 14-21 days, HSC transplantation should be considered. However, in situations where high doses have been delivered, the damage to the bone marrow becomes less relevant and the prognosis of these patients depends on the extent of the damage to organs other than the bone marrow sc. the lungs, gastrointestinal tract, and skin. These patients have a greater risk of developing fatal multi-organ failure MOF, even if the bone marrow aplasia has been successfully managed. Supportive care should include protective isolation (reverse barrier nursing) but that requires an adequate infrastructure and may involve international cooperation. Supportive therapy and specific therapeutic approaches are required in every case. However, the circumstances change radically in the event of radiation disasters, intentional releases of radiological materials on a mass scale, and the use of a nuclear weapon (armed conflicts and terrorist attacks) and the above-mentioned management of triage and medical treatment becomes invalid.

\section{CONCLUSIONS}

Initial emergency procedures with patients exposed to high doses of ionising radiation involve various EMS resources. Radiation triage is an indispensable part of medical care management in case of radiation incidents. Early rescue procedures/interventions are as follows: detecting radiation, assessing the radiation doses and their health effects on an individual's body incl. developing ARS. Type of exposure, the radiation-absorbed dose, additional traumatic injuries determine the organization of medical responses. The organ specific grading to assess prognostic aspects of ARS (grading codes: Ni, Ci, Gi, Hi, $\mathrm{RC}$ ) enables and enhances communication and cooperation between centres in the country and abroad. The increasing risk of radiation events necessitates the management of medical care based on effective triage that is a crucial skill of EMS teams.

1. Triage category depends on the nature and extent of physical injury. 
2. Although other injuries may be minimal, treatment guidelines should be followed for patients receiving a whole-body radiation dose greater than $3 \mathrm{~Gy}$.
3. The „expectant” category applies to patients who have no signs of life or suffered fatal injuries with low chances of survival.

Table: 1. Dose-depending triage categories for patients with and without combined injuries.

$\begin{array}{llll}\begin{array}{l}\text { Conventional triage categories } \\ \text { for injuries without exposure to } \\ \text { radiation }\end{array} & \text { Changes in triage categories after whole-body irradiation } & \text { E,5 Gy-10 Gy } \\ \text { Delayed } & \text { Delayed } & \text { Variable } 1 & \text { Expectant } \\ \text { Immediate } & \text { Immediate } & \text { Immediate } & \text { Expectant } \\ \text { Minimal } & \text { Minimal } & \text { Minimal 2 } & \text { Minimal } 2 \\ \text { Expectant } 3 & \text { Expectant } & \text { Expectant } & \text { Expectant } \\ \text { Absent } & \text { Ambulatory monitoring } & \text { Ambulatory monitoring with routine care and hospitalization as needed }\end{array}$

Source: Based on source [41].The military triage system was modified to develop priorities for therapy of irradiated patients and combined-injury patients.

Attention: Military triage is associated with a specific tactical situation

Table 2. Assessment of prodromal phase depending on the amount of absorbed dose of ionizing radiation.

\begin{tabular}{|c|c|c|c|c|c|}
\hline Symptoms & Mild (1-2Gy) & Moderate (2-4 Gy) & Severe (4-6 Gy) & Very severe (6-8 Gy) & Lethal (> 8 Gy) \\
\hline Vomiting & $>2 \mathrm{~h}$ after exposure & 1-2 $\mathrm{h}$ after exposure & $\begin{array}{l}\text { Earlier than } 1 \mathrm{~h} \text { after } \\
\text { exposure }\end{array}$ & $\begin{array}{l}\text { Earlier than } 30 \text { min after } \\
\text { exposure }\end{array}$ & $\begin{array}{l}\text { Earlier than } 10 \text { after } \\
\text { exposure }\end{array}$ \\
\hline Diarrhoea & None & None & Mild & Heavy & Heavy \\
\hline Headache & Slight & Mild & Moderate & Severe & Severe \\
\hline Consciousness & Unaffected & Unaffected & Unaffected & May be altered & Unconsciousness \\
\hline Body temperature & Normal & Increased & Fever & High Fever & High Fever \\
\hline Medical response & Outpatient observation & $\begin{array}{l}\text { Observation in general } \\
\text { hospital, treatment in } \\
\text { specialized hospital if } \\
\text { needed }\end{array}$ & $\begin{array}{l}\text { Treatment in specialized } \\
\text { hospital }\end{array}$ & $\begin{array}{l}\text { Treatment in specialized } \\
\text { hospital }\end{array}$ & $\begin{array}{l}\text { Palliative treatment } \\
\text { (symptomatic only) }\end{array}$ \\
\hline
\end{tabular}

Source: Based on source [23].

Table 3. Overall prognostic aspects of the ARS on the organ specific grading.

\begin{tabular}{|c|c|c|c|c|}
\hline \multirow{2}{*}{ Organ system } & \multicolumn{4}{|c|}{ Grading and severity of damage } \\
\hline & 1: mild damage & 2. moderate damage & 3. severe damage & 4. serious/fatal damage \\
\hline $\mathrm{N}$ & Recovery certain & Recovery with possibile deficyt & Recovery with severe deficit & Recovery most unlikely \\
\hline H & Autologous recovery certain & Autologous recovery likely & Autologous recovery possible & $\begin{array}{l}\text { Autologous recovery most } \\
\text { unlikely }\end{array}$ \\
\hline$C$ & Recovery certain & Recovery without deficit likely & Recovery with deficit likely & $\begin{array}{l}\text { Recovery most unlikely or with } \\
\text { serious deficit }\end{array}$ \\
\hline G & Recovery certain & Recovery with possibile deficit & Recovery may be possible & Recovery most unlikely \\
\hline
\end{tabular}

Source: Based on source [30]. 


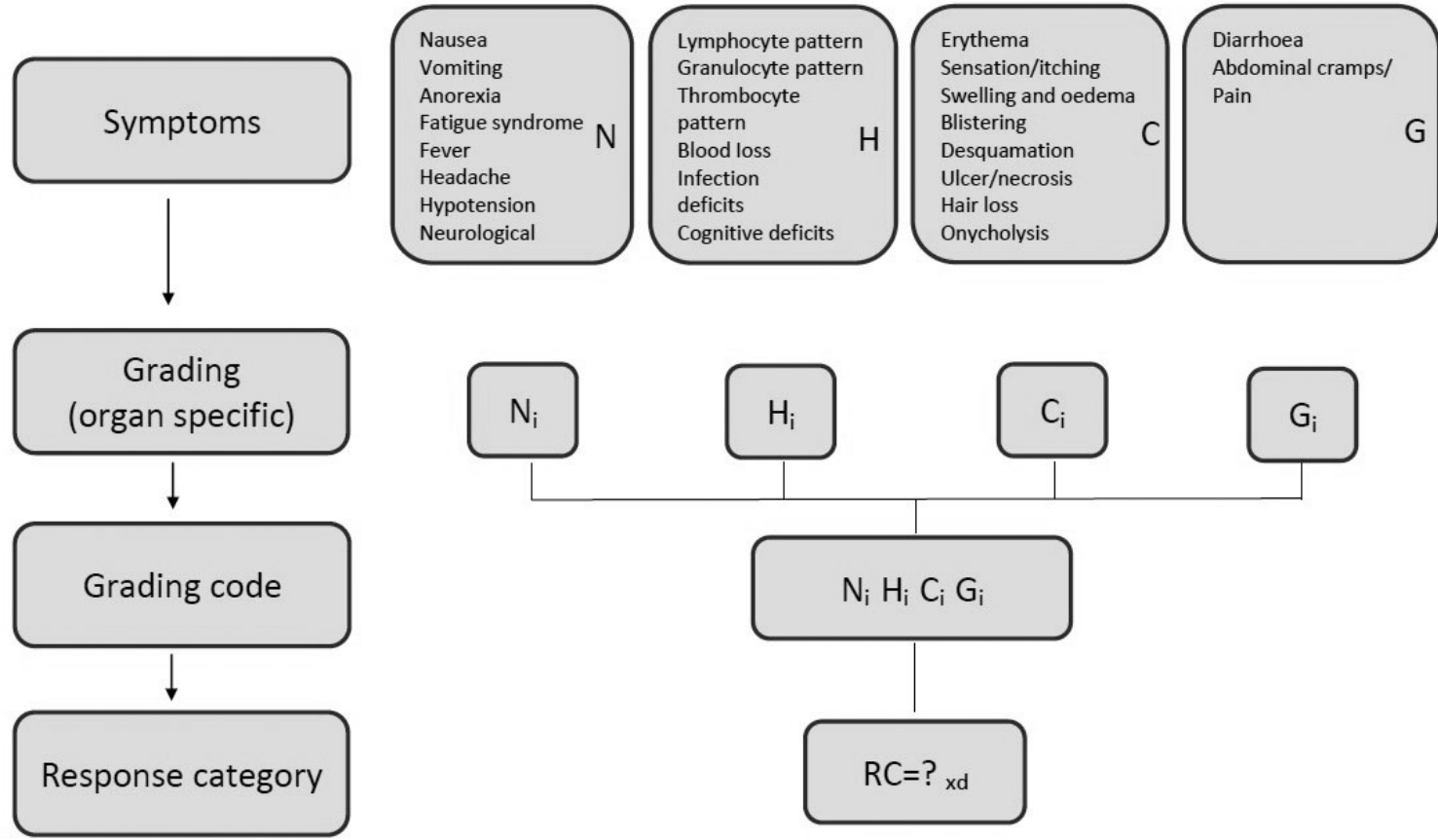

$\mathrm{N}=$ Neurovascular system $\mathrm{H}=$ Haematopoietic system $\mathrm{C}=$ Cutaneous system $\mathrm{G}=$ Gastrointestinal system I=Severity index 1-4 $x d=$ Time point $(\mathrm{x})$ at which RC was established; measured in days (d) after beginning of exposure

Fig. 1. ARS clinical evaluation. Source: Based on source [30].

\section{REFERENCES}

1. Polska Agencja Atomistyki. Zdarzenie radiacyjne. http://www.paa.gov.pl/strona-135-zdarzenia_radiacyjne.html [accessed: 23.01.2020]

2. Rozporządzenie Rady Ministrów z dnia 18 stycznia 2005 r. w sprawie planów postępowania awaryjnego w przypadku zdarzeń radiacyjnych. Dz.U. 2005 nr 20 poz. 169.

3. U.S. Department of Health and Human Services. REMM Radiation Emergency Medical Management: Procedures for Radiation Decontamination: https://www.remm.nlm.gov/ext_contamination.html [accessed: 20.01.2020]

4. López M, Martín M. Medical Management of the Acute Radiation Syndrome, Rep Pract Oncol Radiother 2011;16 (4):138-46.

5. Fijuth J. Radiobiologia. In: Pruszyński B, Cieszanowski A (eds) Radiologia - diagnostyka obrazowa RTG, TK, USG i MR. Wyd. PZWL, Warszawa 2016, pp. 76-77.

6. Hatchett RJ, Kaminski JM, Goans RE. Nuclear and radiological events. In: Koenig KL, Schultz CH (eds). Koenig and Schultz's Disaster Medicine: Comprehensive Principles and Practices. Cambridge, England: Cambridge University Press, 2009, pp. 477-510.

7. Anno GH, Young RW, Bloom RM, Mercier JR. Dose response relationships for acute ionizing-radiation lethality. Health Phys. 2003;84;565-75.

8. Peter RU, Gottlober P. Management of Cutaneous Radiation Injuries: Diagnostic and Therapeutic Principles of the Cutaneous Radiation Syndrome. Milit Med. 2002;167(Suppl. 1):110.

9. https://www.cdc.gov/nceh/radiation/emergencies/criphysicianfactsheet.html [acessed: 27.01.2020]

10. Peter RU. Cutaneous radiation syndrome in multi-organ failure. BJR. 2005;78(Suppl 27,1):180-184.

11. Hick JL, Bader JL, Coleman CN, et al. Proposed "Exposure And Symptom Triage" (EAST) Tool to Assess Radiation Exposure After a Nuclear Detonation. Disaster Med Public Health Prep. 2018;12;386-395.

12. Buddemeier BR, Dillon MB. Key Response Planning Factors for the Aftermath of Nuclear Terrorism. https://www.remm.nlm.gov/IND_ResponsePlanning_LLNL-TR-410067.pdf. Published August 2009. [accessed: 27.01.2020] 
13. Waselenko JK. Medical Management of the Acute Radiation Syndrome: Recommendations of the Strategic National Stockpile Radiation Working Group. An Inter Med. 140(12),2004;1037-1057.

14. Wieczorek A, Góźdź S. Zespół żołądkowo-jelitowy Ostrej Choroby Popromiennej In: Janiak M, Wójcik A (eds). Medycyna zagrożeń i urazów radiacyjnych. Wyd. PZWL, Warszawa, 2004, pp. 67-71.

15. Hartman A, Bojar H, Zamboglou N, et al. The significance of clinical prodromes for dosage estimation after whole-body radiation exposure. Strahlenther Onkol 1994;170:538-44.

16. Berger ME, Christensen DM, Lowry PC Jones OW, Wiley AL. Medical Management of Radiation Injuries: Current Approaches. Occupat Med 2006;56(3):162-72.

17. Fliedner TM, Friesecke I, Beyrer K. Medical Management of Radiation Accidents - Manual on the Acute Radiation Syndrome. Published by The British Institute of Radiology 2001, pp.3-13.

18. Donnelly EH, Jeffrey B, Nemhauser JM, et al. Acute Radiation Syndrome: Assessment and Management. South Med J 2010;103 (6):541-46.

19. TMT Handbook. Triage, monitoring and treatment of people exposed to ionising radiation following a malevolent act. https://www.remm.nlm.gov/tmt-handbook-20091.pdf [accessed: 23.01.2020]

20. Macià i Garau M, Lucas Calduch A, López EC. Radiobiology of the acute radiation syndrome. Rep Pract Oncol Radiother 2011;16(4):123-130.

21. Dubray B, Girinski T, Thomas HD, et al. Post-irradiation hyperamylasemia as a biological dosimeter. Radiother Oncol 1992;24:21-26.

22. Hofmann R, Schreiber GA, Willich N, et al. Increased serum amylase in patients after radiotherapy as a probable bioindicator of a radiation exposure. Strahlenther Onkol 1990;166:688-695.

23. International Atomic Energy Agency. Diagnosis and Treatment of Radiation Injuries. Safety Report Series No. 2.Vienna: IAEA, 1998.

24. Pacyniak I. Dozymetria biologiczna. Cytogenetyczna rekonstrukcja otrzymanej dawki promieniowania jonizującego metodą markerów biologicznych. Politechnika Warszawska, Warszawa 2012/2013, pp. 1-43.

25. Peter RU. Cutaneous radiation syndrome-clinical and therapeutic aspects. Radiant Protect Bull. 1996;183:19-25.

26. The medical aspects of radiation incidents. Radiation Emergency Assistance Center/Training Site. REACT/TS. Accessed November 2010. https://orise.orau.gov/reacts/documents/medical-aspects-of-radiation-incidents.pdf [14.01.2020]

27. Berger ME, Christensen DM, Lowry PC, et al. Medical Management of Radiation Injuries: Current Approaches. Occupat Med. 2006;56 (3):162-72.

28. The medical aspects of radiation incidents. Radiation Emergency Assistance Center/Training Site. REACT/TS. Accessed November 2010. http://www.orise.orau.gov/reacts [11.12.2019]

29. Guskova AK, Baranov AE, Gusev IA. Acute radiation sickness: underlying principles and assessment. In: Gusev IA, Guskova AK, Mettler FA (eds). Medical Management of Radiation Accidents. 2nd edn. Boca Raton: CRC Press, 2001, pp. 33-51.

30. Fliedner TM, Friesecke I, Beyer K (eds). Medical Management of Radiation Accidents: Manual on the Acute Radiation Syndrome. Oxford: British Institute of Radiology, 2001

31. Blajchman MA. Immunomodulation and blood transfusion. Am J Ther. 2002;9:389-95.

32. Hebert PC, Fergusson D, Blajchman MA, et al. Clinical outcomes following institution of the Canadian universal leukoreduction program for red blood cell transfusions. JAMA. 2003;289:1941-9.

33. Singh VK, Newman LV, Berg NA, et al. Animal Models for Acute Radiation Syndrome Drug Discovery. Expert Opin Drug Discov. 2015;10(5):497-517.

34. Dainiak N. Rationale and recommendations for treatment of radiation injury with cytokines. Health Phys. 2010;98(6):838-842.

35. Krivokrysenko VI, Shakhov AN, Singh VK, et al. Identification of Granulocyte Colony-Stimulating Factor and Interleukin-6 as Candidate Biomarkers of CBLB502 Efficacy as a Medical Radiation Countermeasure. J Pharmacol Experiment Ther. 2012;343(2):497-508.

36. Garofalo MC, Ward AA, Farese AM, et al. A pilot study in rhesus macaques to assess the treatment efficacy of a small molecular weight catalytic metalloporphyrin antioxidant (AEOL 10150) in mitigating radiation-induced lung damage. Health Phys 2014;106:73-83.

37. Stickney DR, Dowding C, Garsd A, et al. 5-androstenediol stimulates multilineage hematopoiesis in rhesus monkeys with radiation-induced myelosuppression. Int Immunopharmacol 2006;6:1706-13. 
38. López M, Martín M. Medical Management of the Acute Radiation Syndrome. Rep Pract Oncol Radiother 2011;16(4):138-46.

39. Culy CR, Spencer CM. Amifostine: an update on its clinical status as a cryoprotectant in patients with cancer receiving chemotherapy or radiotherapy and its potential therapeutic application in myelodysplastic syndrome. Drugs 2001;61:641-84.

40. Hughes WT, Armstrong D, Body GP, et al. Guidelines for the use of antimicrobial agents in neutropenic patients with cancer. Clin Infect Dis 2002;34:730-51.

41. Flynn DF, Goans RE. Triage and treatment of radiation and combined-injury mass casualties In: Mickelson AB (ed.). Medical Consequences of Radiological and Nuclear Weapons. The Borden Institute, U.S. Army Medical Department Government Printing Office, 2013, pp.39-71

\section{ORCID AND CONTRIBUTIONSHIP *}

Wiktoria Kudła - 0000-0002-0072-0652 A,B,C,,D,E

Arkadiusz Trzos - 0000-0002-4390-0901 A,B,C,0,E,F,

Karol Łyziński - 0000-0003-3292-2459 C,0

\section{CONFLICT OF INTEREST}

Authors declare no conflict of interest.

\section{ADDRESS FOR CORRESPONDENCE}

Arkadiusz Trzos

Uniwersytet Jagielloński Collegium Medicum, Wydział Lekarski, Katedra Anestezjologii i Intensywnej Terapii, Zakład Medycyny Katastrof i Pomocy Doraźnej ul. Kopernika 19, 31-501 Kraków, Poland tel. + 48604266992

e-mail: arkadiusztrzos@gmail.com 


\title{
THE USE OF SURVIVAL TECHNIQUES IN RESCUE PROCEEDINGS ON THE EXAMPLE OF THE USE OF MEDICINAL PLANTS
}

\author{
Łukasz Kucharski ${ }^{1,23}$
}

\author{
1 FACULTY OF MEDICAL SCIENCES, UNIVERSITY OF SOCIAL SCIENCES IN LUBLIN, LUBLIN, POLAND \\ 2 HOSPITAL EMERGENCY DEPARTMENT OF THE INDEPENDENT PUBLIC HEALTH CARE CENTER IN WŁODAWA, WLODAWA, \\ POLAND \\ 3 THE MEDICAL TEAM OF THE POLICE PREVENTION DEPARTMENT IN LUBLIN, LUBLIN, POLAND
}

\begin{abstract}
Introduction: The text is a response to the results of research conducted on medical rescuers and students of the field of emergency medicine, which unambiguously present a lack of knowledge on the one hand, and the need to acquire knowledge in the field of survival for rescue operations on the other. The work contains one of the survival techniques used in the field using the surrounding environment in the form of the use of plants that have antihemorrhagic properties.

The aim: In this text, the main attention has been paid to aspects related to the use of survival techniques in rescue proceedings. At the same time, an attempt was made to present the use of medicinal plants in rescue operations both at the level of first aid and medical rescue operations in extreme conditions, as a complement to the multimodal approach to a trauma patient.

Material and methods: The study was conducted at the turn of February and March 2020, which was attended by 52 part-time students in the field of emergency medicine at the University of Social Sciences in Lublin. Among the research techniques, a proprietary survey created for the purpose of verifying the topic of work was used, consisting of the record and questions determining the legitimacy of using survival techniques in rescue operations.

Results: Almost all of the surveyed students believe that theoretical and practical knowledge in the field of survival would be useful in the profession of a paramedic, while the majority of respondents claim that first degree studies in the field of emergency medicine do not prepare a paramedic to work in crisis and extreme conditions.

Conclusions: There is potential that gives us the natural environment in the form of plants that can be successfully used in rescue operations in difficult terrain. In addition, both students and paramedics show interest and training need in the use of survival techniques used in rescue operations. Therefore, one should strive to create a unified framework program for teaching future paramedics, based on current knowledge in the field of survival techniques used in emergency medical services already at the Higher Education level.
\end{abstract}

Key words

\section{INTRODUCTION}

The primary purpose of the text is to attempt to present a new look at aspects related to survival techniques used in rescue operations, including medicinal plants. The text is a response to the results of research conducted on paramedics and students of medical rescue, which clearly show on the one hand the lack of knowledge, and on the other hand the need to acquire knowledge in the field of survival in terms of rescue operations. The work contains one of the survival techniques used in the field using the surrounding environment in the form of plants commonly recognized as weeds that have antihemorrhagic properties.

The work is a continuation of the research that was carried out by the author in 2014 on paramedics rescuing the territory of the entire country, aimed at determining the place and role of survival in emer- gency medical services [1]. Operation under survival will therefore consist of gradually entering the danger zone after prior preparation. When the situation is recognized, planned and controlled, it ceases to be extreme. This may prove that in survival it is necessary to constantly train, gain experience and improve their skills in order to change an extreme situation into a typical situation, which will also translate into emergency medicine.

\section{THE AIM}

In this text, the main attention has been focused on aspects related to the use of survival techniques in rescue proceedings. At the same time, an attempt was made to present the use of medicinal plants in rescue operations both at the level of first aid and medical rescue operations in extreme conditions, as a complement 
to the multimodal approach to a trauma patient. In addition, attempts to raise subjects related to survival in conditions of rescue procedures are dictated by experiences related to actions in unusual conditions in which a paramedic operates almost every day.

\section{MATERIAL AND METHODS}

The study was conducted at the turn of February and March 2020, which was attended by 52 part-time students in the field of emergency medicine at the University of Social Sciences in Lublin. The respondents gained professional experience mainly through participation in apprenticeships, volunteering in units of the State Emergency Medical Service and work in rescue structures. Most of the respondents were professionally connected, among others with: Medical Rescue Teams, Hospital Emergency Department, Water Volunteer Ambulance Service and uniformed formations such as the State Fire Service, the Army, the Police, and the Border Guard.

In this work, research techniques used a proprietary survey created for the purpose of verifying the topic of work, consisting of the record and questions determining the legitimacy of the use of survival techniques in rescue operations. In addition, an interview was conducted among the respondents and a content observation and analysis technique was used. The next part of the text contains a description of commonly occurring medicinal plants exhibiting antihemorrhagic properties, which can be successfully used at any level of providing assistance to injured persons and in authorship.

\section{RESULTS}

First, the respondents were asked to answer the question whether theoretical and practical knowledge of survival would be useful in the profession of a paramedic [Fig. 1]. The results show that almost $95 \%$ of students consider it appropriate to acquire knowledge and skills in survival techniques in rescue. Based on the students' answers, one can draw unequivocal conclusions proving the possibility of using survival techniques and knowledge in future work. To confirm, the results of tests carried out on paramedics actively working in rescue structures were at a similar level [1].

Going a step further, students were asked whether they believe that first degree studies prepare future paramedics for work in crisis and extreme conditions [Fig. 2]. The results show that almost 93 percent of respondents describe their level of knowledge and skills acquired from the curriculum as insufficient. Comparing the above results with the results carried out in 2014 on paramedics, one can observe a correlation indicating huge training shortages in the aspect of actions in crisis situations [1].

Analyzing the further part of the topic related to the process of training paramedics in terms of action in unusual situations, it was examined whether during the professional work there were situations in which students felt lack of training [Fig. 3]. Over $70 \%$ of respondents felt helpless when giving emergency medical services in severe stress. How do the obtained results of future rescuers relate to the results of active practitioners? Research conducted on para-

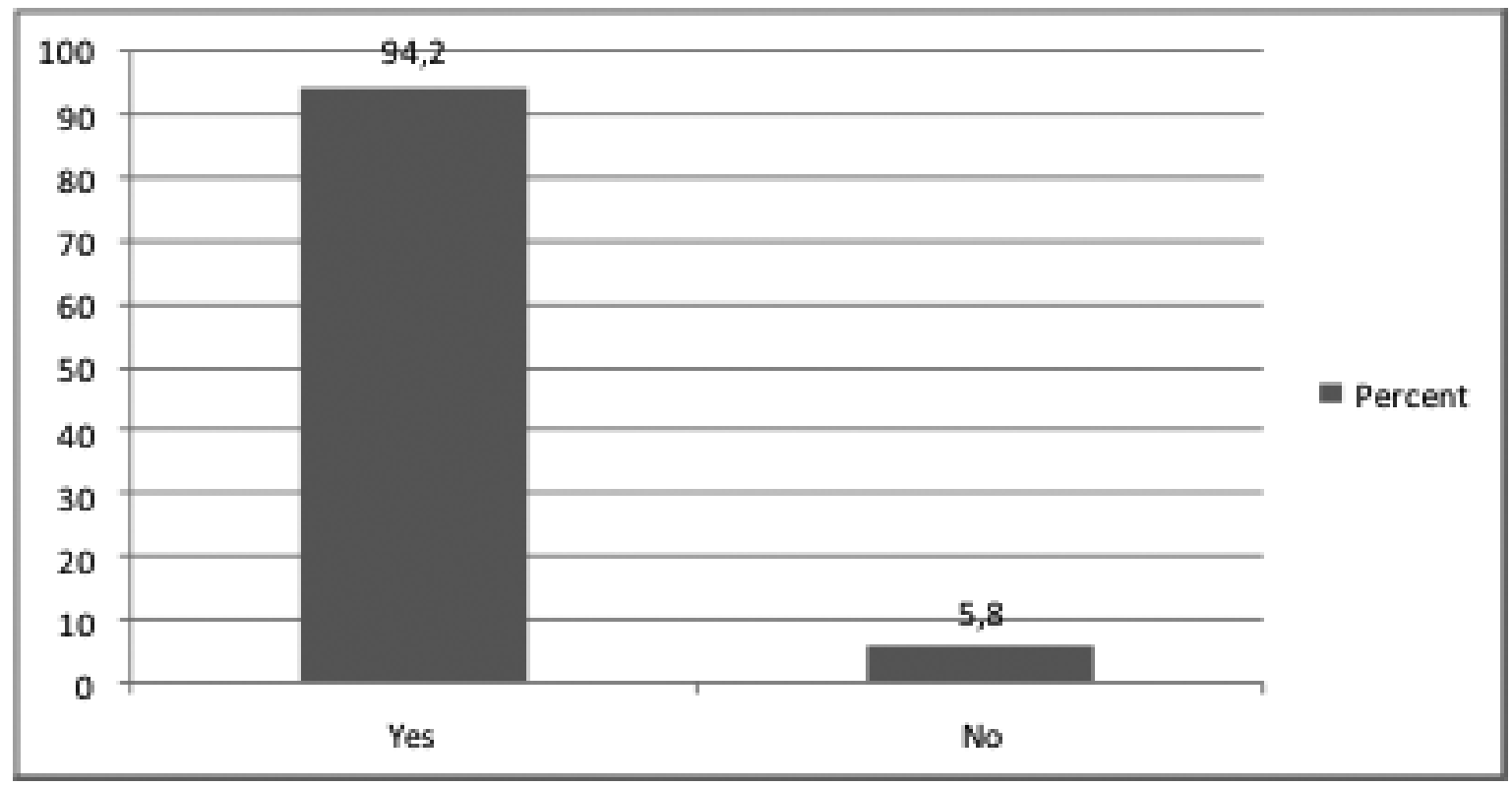

Fig. 1. Do you think theoretical and practical knowledge of survival would be useful in the profession of a paramedic?

Source: own study. 


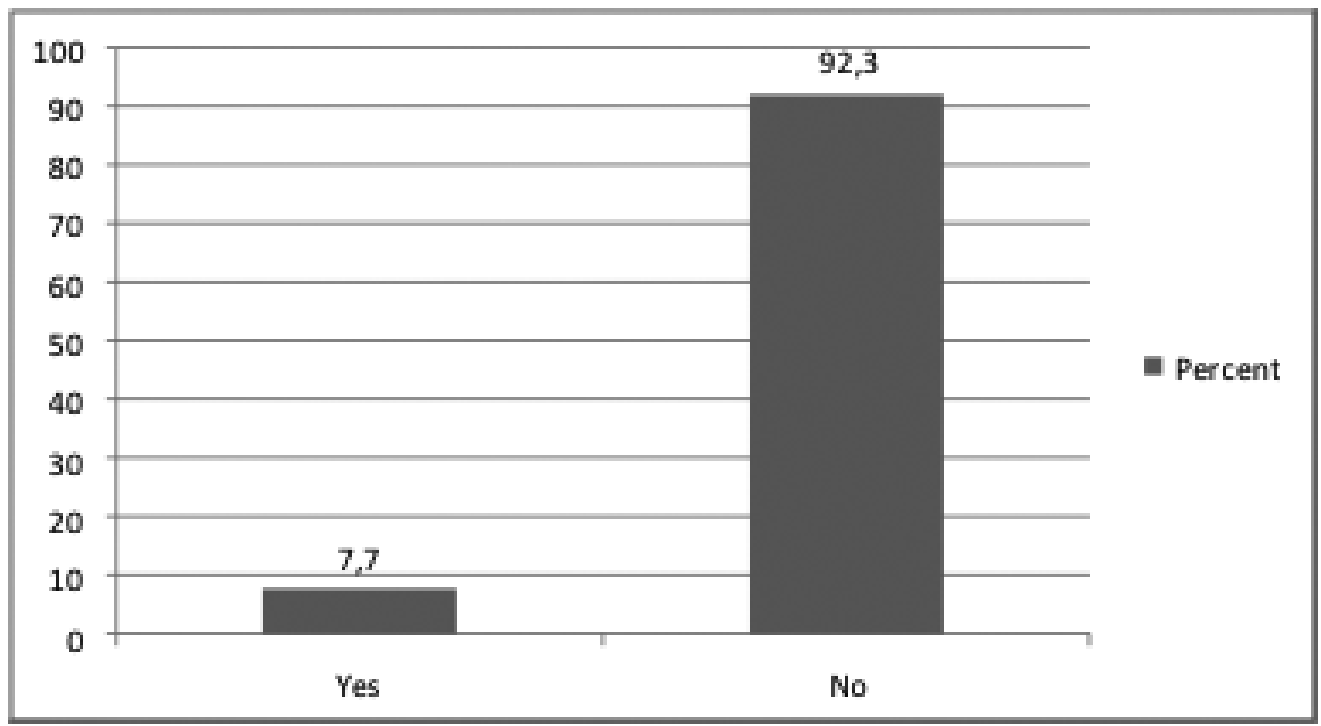

Fig. 2. Do first degree studies prepare a paramedic to work in crisis and extreme conditions?

Source: own study

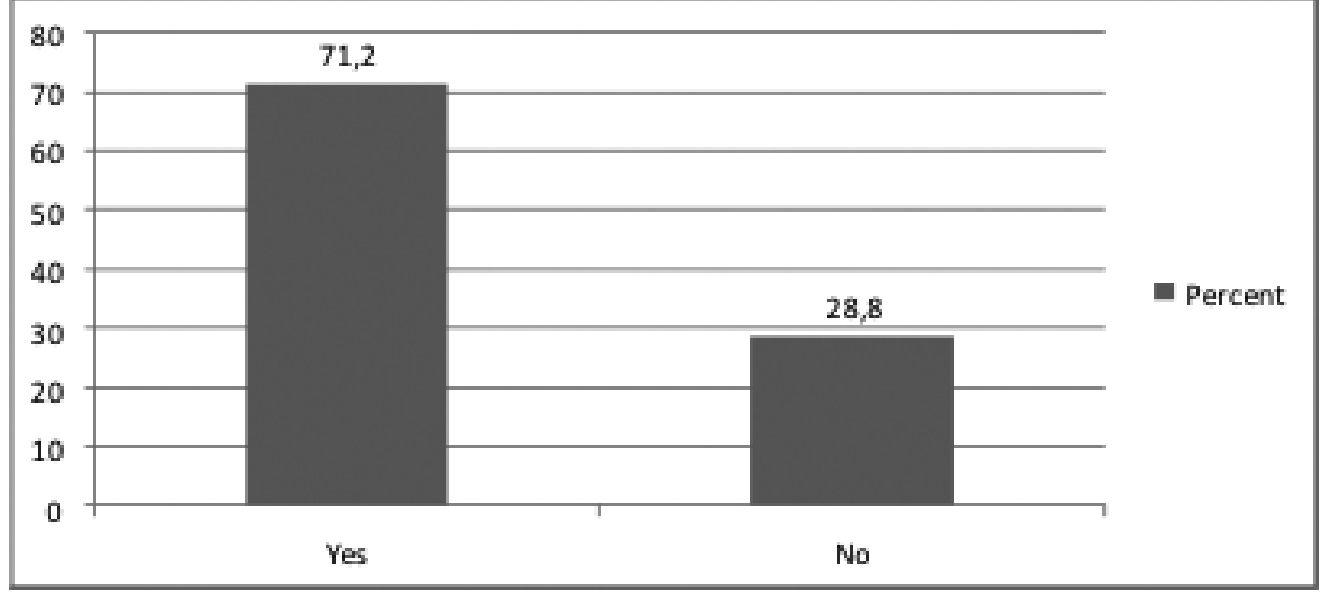

Fig. 3. Did you experience a situation where you felt helpless due to lack of training during your work / apprenticeship? Source: own study

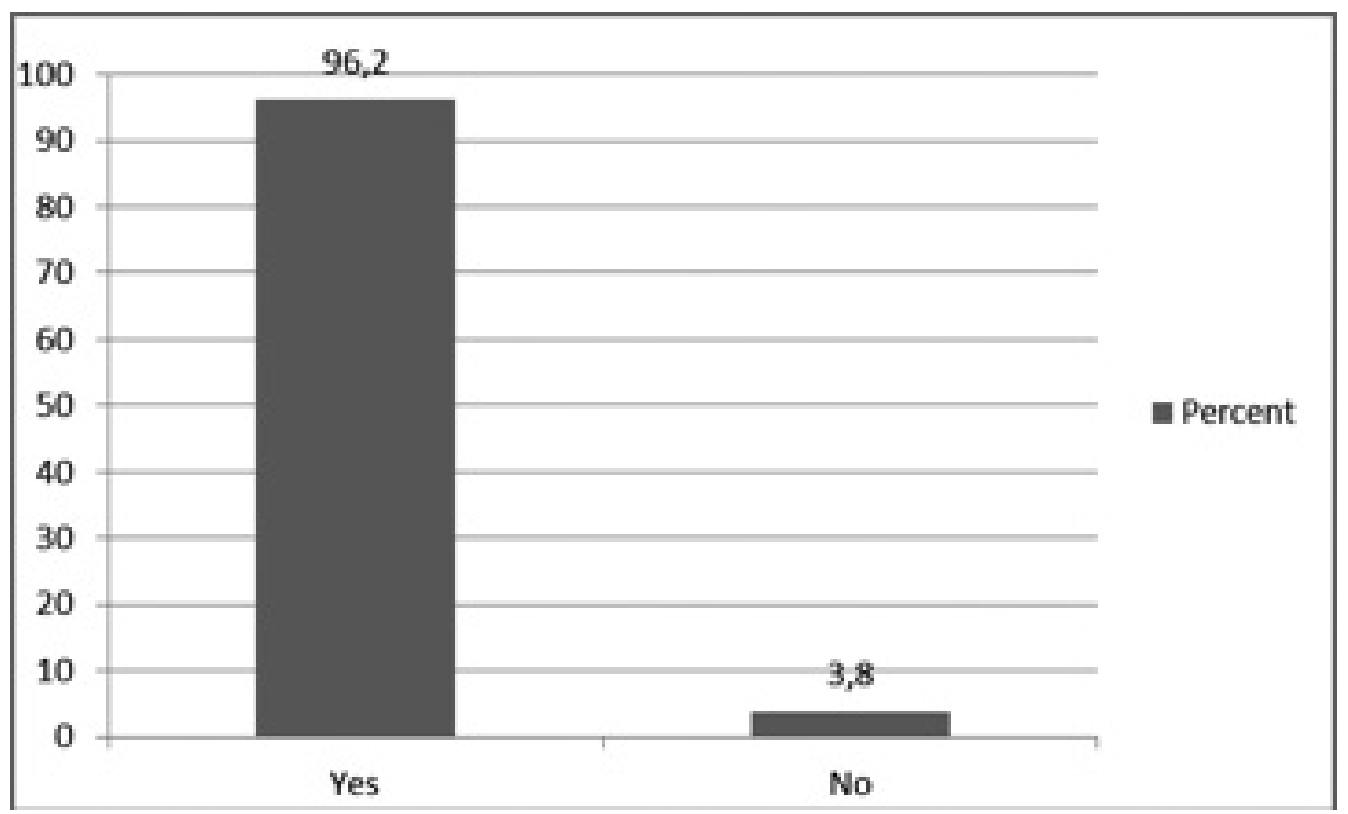

Fig. 4. Do you think that universities conducting the field of emergency medicine should introduce mandatory training in behavior in extreme and atypical situations?

Source: own study. 
medics representing the territory of the whole country shows that over $56 \%$ of respondents confirm the lack of training, and thus the resulting helplessness in providing assistance to victims [1].

By analyzing the research results obtained, it can be concluded that there is a huge room for maneuver to conduct training activities in the field of survival with a reference to emergency medicine. The above statement has also been confirmed by research that states that universities conducting the field of emergency medicine should introduce mandatory training in the field of behavior in extreme and unusual situations [Fig. 4].

In this text, only selected edible plants, commonly found throughout the country, considered by most to be useless weeds are proposed. Due to the nature of the issue discussed directly regarding emergency rescue under extreme conditions, plants with antihemorrhagic properties were presented. In order to minimize the occurrence of any side effects, the author chose plants that were used by him personally, it means a taste test was carried out along with the consumption of individual parts of plants. Massive haemorrhage along with unconscious conditions, including cardiac arrest will require the rescuer to have the appropriate skills and knowledge. In addition, the use of plants in unusual conditions, where dealing with the injured person or authorizing, will require the rescuer to operate under time pressure.

The use of survival techniques in the form of knowledge of plants that can really become the last resort for both the rescuer and the rescued person can be successfully used in difficult terrain both as a supplement to therapeutic procedures performed by medical rescuers as part of medical rescue operations or ser-

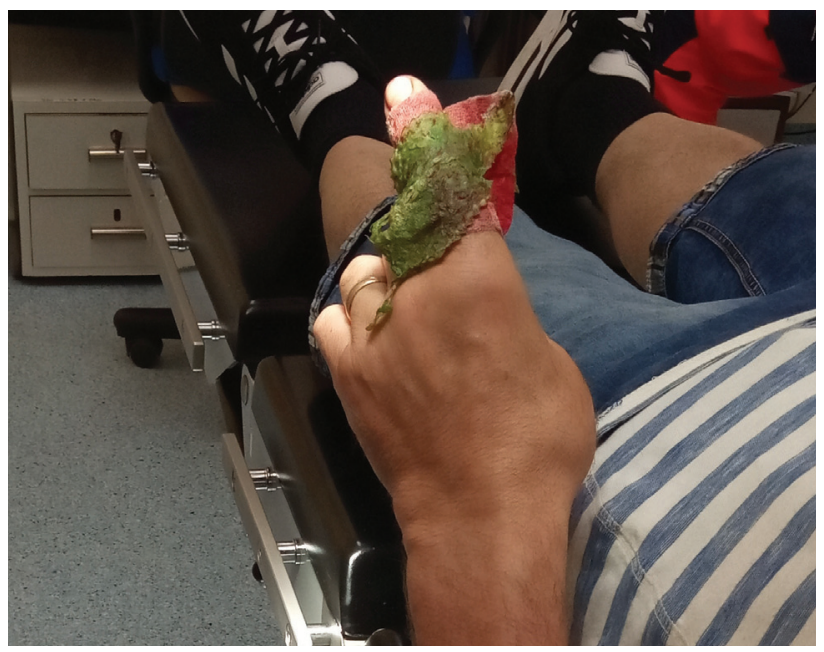

vices health conditions, for example in the conditions of isolation, natural disasters, armed conflicts, activities in a mountain environment or forest complex, as well as in terms of first aid. Bearing in mind that the primary goal of any rescue operation is the life and health of the injured person, one should strive to use all possible methods and techniques of rescue, even those unconventional. What is the reference to medical practice and law? The Act on the State Emergency Medical Services defines first aid as a set of actions taken to save a person in a state of sudden health emergency performed by the person in the scene $[2,3]$. Going forward, define the state of sudden health threat as a condition involving the sudden or anticipated appearance of symptoms of deterioration in a short time, which can be a direct consequence of serious damage to the body's functions or bodily injury or loss of life, requiring immediate medical rescue and treatment $[2$, $3]$. There is one conclusion, each of us should do everything to save the life of another human being using knowledge and available forces and means. Knowledge of the natural environment that surrounds us may therefore complement the field first aid kit in situations that may seem hopeless at first glance that require us to take effective help from our travel companions or family members.

The plants in question, depending on the place where the assistance will be provided, as well as the time that will play a major role in massive bleeding and prolonged transport time will be able to be used both directly at the site of injury immediately after breaking. It is also possible to prepare an infusion, juice or macerate, but it will require a longer time, which in the conditions of isolation, or prolonged waiting for help will be measurable [Fig. 5].

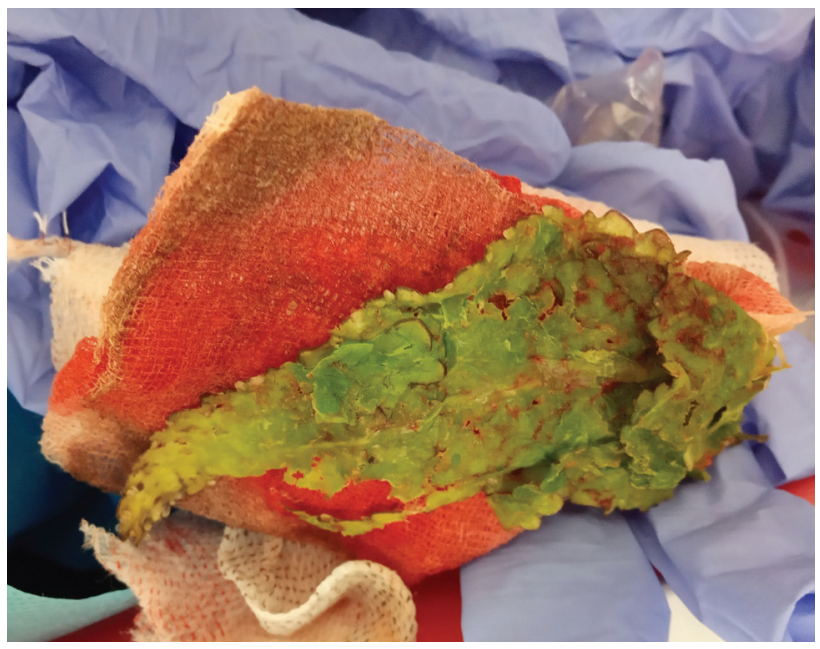

Fig. 5. The patient reported to the Hospital Emergency Department with deep cut wounds from a finger strike. In addition to gauze and a knitted band, mullein leaf was used as first aid. The injured person said that after using the plant in the subjective assessment, the intensity of pain and the dynamics of bleeding decreased.

Source: own study. 


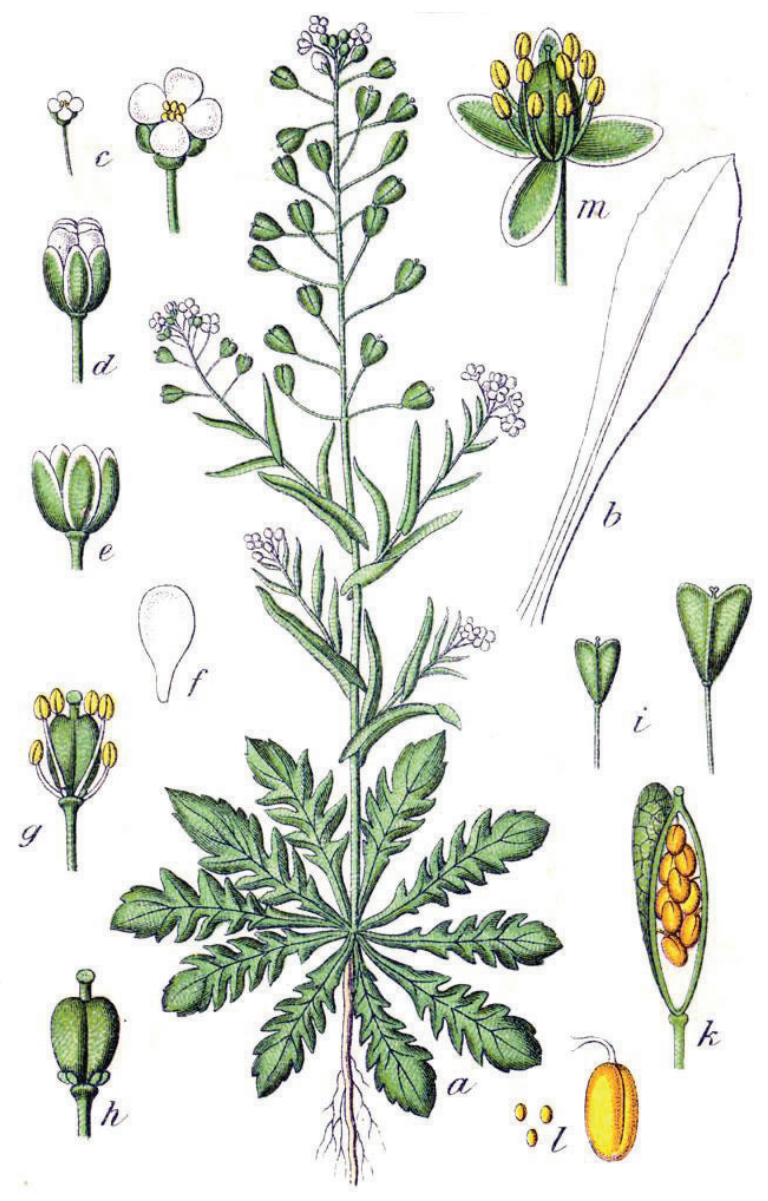

Fig. 6. Tashnik Common (Capsella bursa-pastoris) [6].

Tashnik Common (Capsella bursa-pastoris) [Fig. 6-7] - a plant commonly treated as a field weed, occurring throughout the whole country. Is a plant with edible leaves, fruit and root, both raw and after cooking. Tasznik has healing properties, including antihemorrhagic, disinfectant, diuretic and expectorant. Both common herb and root contain acetylcholine, which has a widening effect on the lumen of blood vessels, which ultimately causes a drop in blood pressure. In addition, almost the entire plant, except for vitamin $\mathrm{C}, \mathrm{K}$ and $\mathrm{A}$, contains a routine that acts as a sealant on blood vessels, thus being of great importance in the situation of bleeding in the field, where medical assistance may not be available. Considering the fact that the most effective blood-clotting effect is shown by a freshly picked plant, it will have its reflection on its use both in the case of long-term nosebleeds, cuts, burns, burns, varicose veins, and in the case of massive bleeding, co-creating a kind of "hemostatic dressing ". The easiest way to control bleeding is by applying the herb directly to the site of injury, making a compress from fresh ground pulp or soaking

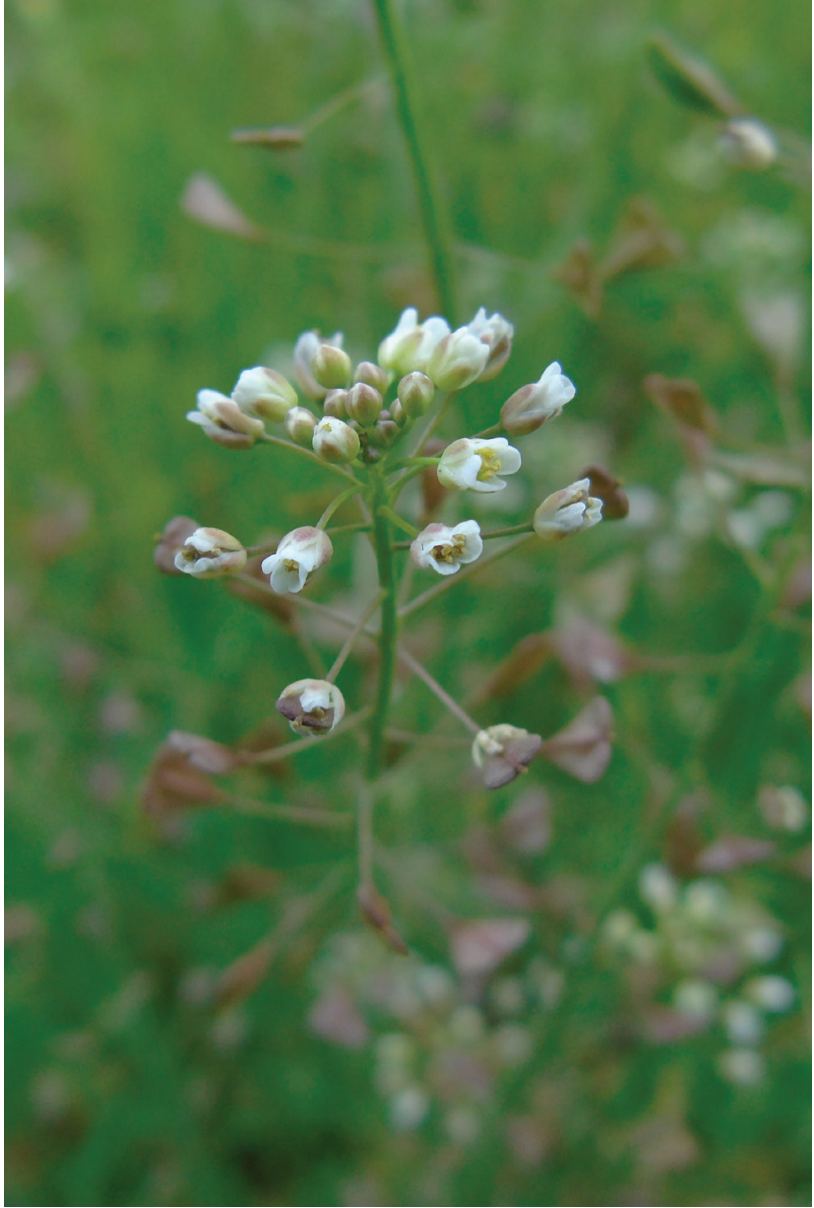

Fig. 7. Tashnik Common (Capsella bursa-pastoris). Source: own study.

the gauze with freshly squeezed juice and applying the dressing directly to the bleeding site or creating "wound packing". Confirmation can be even the use of common scab, as a last resort in massive bleeding from gunshot wounds during World War I, when medical supplies were not available or were lost.

The fresh herb of tashka can easily and quickly prepare juice or macerate, which will be indicated in: diarrhea, inflammation of the urinary tract, disorders of intestinal motility, cholelithiasis and urolithiasis, heavy vomiting, bleeding in the lower and upper digestive tract and hemorrhoids $[9,10]$.

The properties and biological activity of the tea plant has been confirmed in in vivo and in vitro tests. Experiments have shown that the aqueous extract of common peach, shortened the prothrombin time of human citrate plasma by $60 \%$, thus accelerating the blood coagulation process [4]. By analyzing the results of the research, it can be concluded that the tashnik can be successfully used in medicine, as a means of stopping all kinds of long-term bleeding, especially in situations where access to traditional medicines may be difficult. 


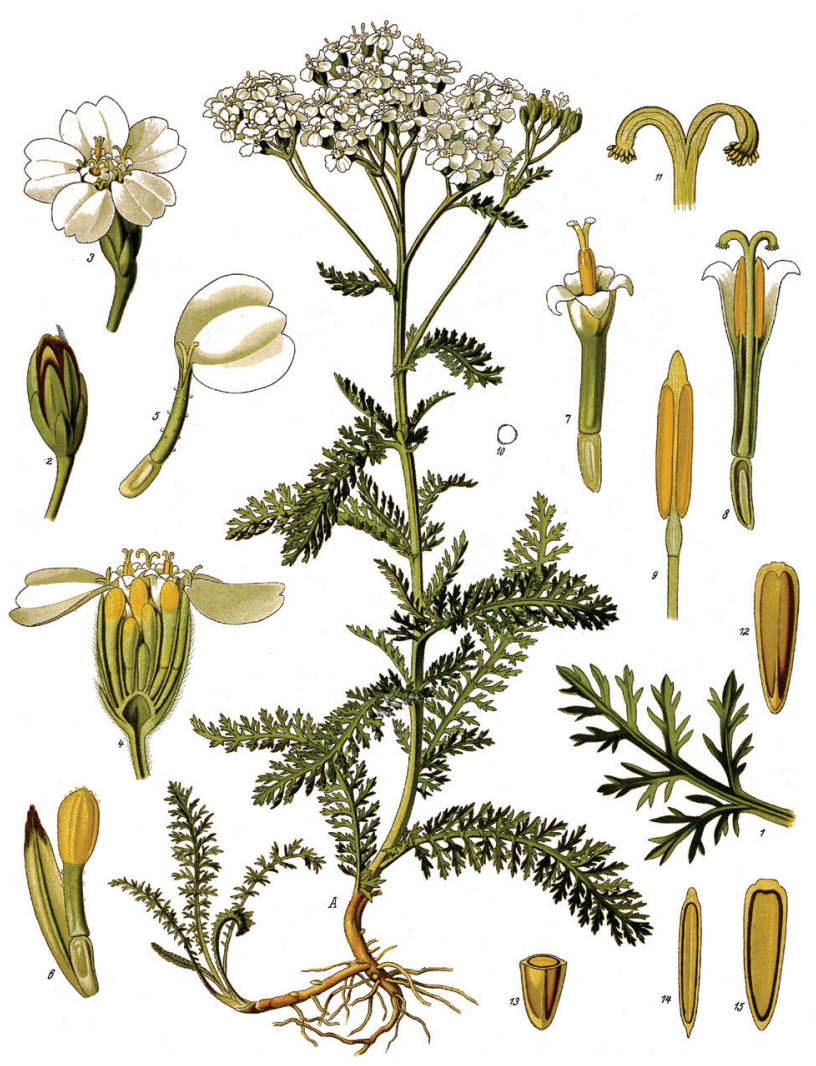

Fig. 8. Yarrow (Achillea millefolium) [7].

Yarrow (Achillea millefolium) [Fig. 8-9] -a characteristic plant, easy to recognize, occurring throughout the country with antibacterial, anti-inflammatory and antihemorrhagic properties. Its phenomenon is the possibility of using local juice of a freshly picked plant in the place of injury in the form of compresses. Referring to the name, it should be noted that the plant has a number of sealing properties for blood vessels for both external and internal bleeding by inhibiting blood leaks inside the capillaries. Herb and yarrow flower owe their large amounts of alkaloids to their haemostatic properties. In order to stop internal bleeding caused, among others gastric and intestinal ulcers, hemorrhoids, esophageal varices, as well as respiratory bleeding can be successfully used by pouring a handful of yarrow herb with a glass of boiling water. In addition to antihemorrhagic properties, the yarrow relieves the symptoms of pharyngitis and stomatitis, reduces migraine headaches, effectively reduces blood pressure and fever [9]. The origin of the Latin name - Achillea may be an interesting fact, according to the legend, the hero of the Iliad was to apply yarrow herb to dress the wounds of his soldiers.

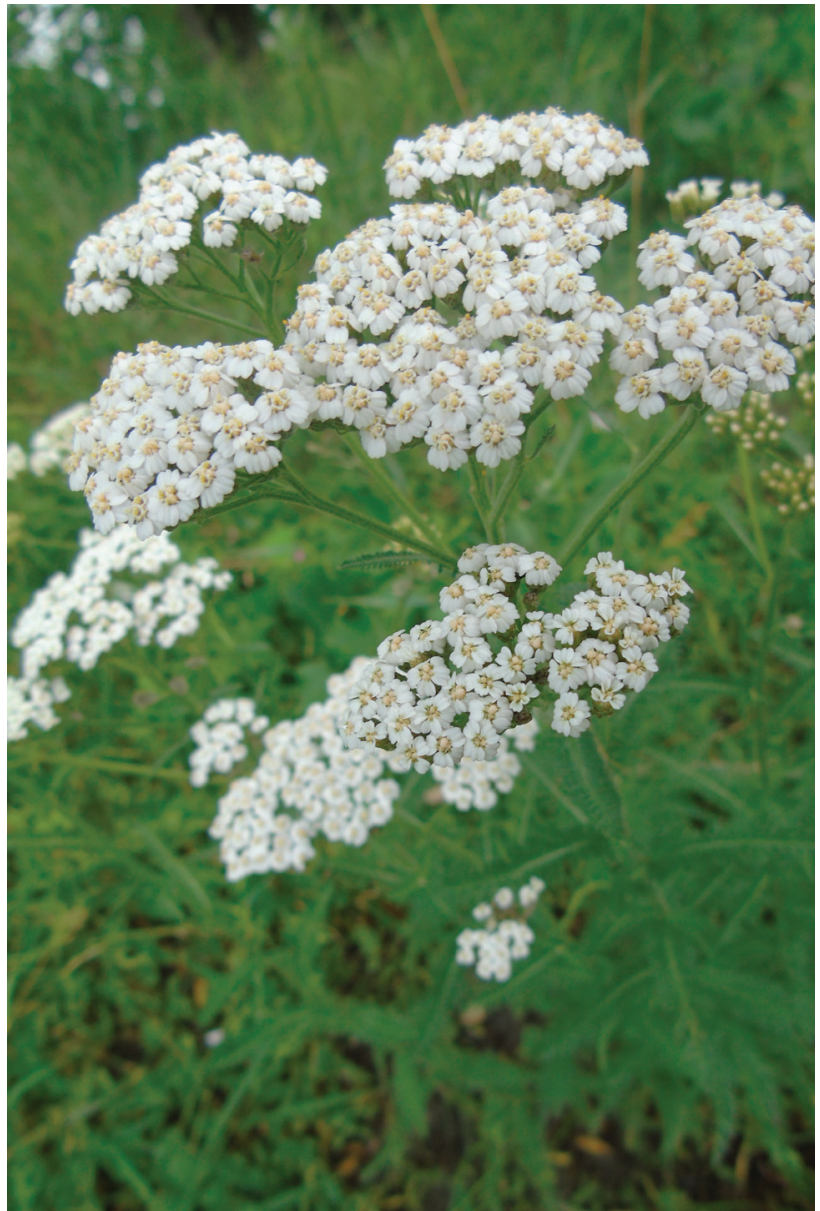

Fig. 9. Yarrow (Achillea millefolium).

Source: own study.

Plantain (Plantago lanceolata) [Fig. 10], [Fig. 11] - the plant is entirely edible, thanks to its high adaptability, it covers the entire territory of Poland. It occurs almost everywhere, i.e. on meadows, pastures, sidewalks, along roads, forest and mountain trails. Plantain medicinal leaves are both medicinal leaves and the whole plant. The widespread occurrence of grandmother gives us a huge room for maneuver in emergency proceedings at the scene of the accident in almost every area. Juice from fresh plantain leaves has antibacterial, astringent and sealing properties, supporting epidermis regeneration and healing. The plant can be applied directly to the injury site to form a leaf compress, slurry or macerate. From the leaves of the plant, you can also prepare a decoction, and then apply in the form of compresses to the site of injury or drink in case of gastric ulcer. Plantain leaves containing, among others flavonoids, tannins, organic acids, vitamin $\mathrm{C}$ and mineral salts (silicon, zinc and iron compounds) will work in the event of bleeding, burns, bruises, or bruises and abrasions of the epidermis. In the past, it was considered a strong plant, because it did not die "even on busy roads despite be- 


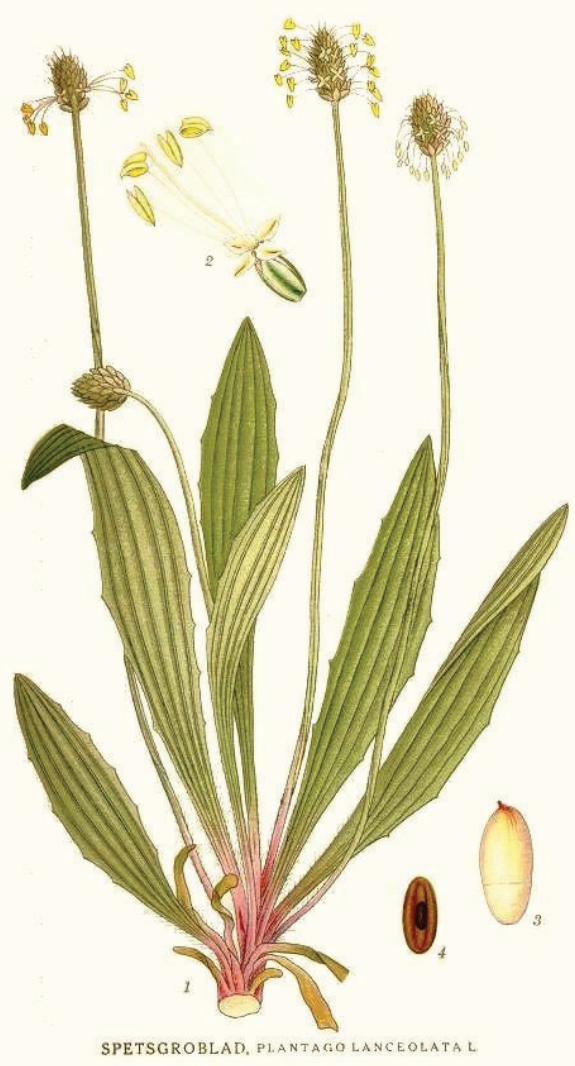

Fig. 10. Plantain (Plantago lanceolata) [8].

ing trampled by horse hooves and running over with iron rims of carts". Its healing qualities were already appreciated in ancient times, where the plantain juice was used for scorpion and snake bites, while in the Middle Ages the plantain leaf compresses helped fractures, suppurating boils, burns and swelling [5].

\section{DISCUSSION}

Looking at the results of research conducted both on medical rescue students and on professionally active medical rescuers, one can observe the same trend related to the problem of training shortage in the field of survival techniques used in medical rescue. On the one hand, the above aspects are related to the paramedics curriculum not adapted to the needs of modern emergency services, on the other hand, the lack of training in terms of survival of persons who already operate in the State Emergency Medical System. Research on the role of survival in medical rescue shows that a medical rescuer in everyday work for the protection of citizens' health encounters unusual and even crisis situations that require them to use survival techniques in the form of: using selfdefense techniques, segregating victims - TRIAGE in mass accidents, activities in the area of natural and technical disasters, the use of water and altitude res-

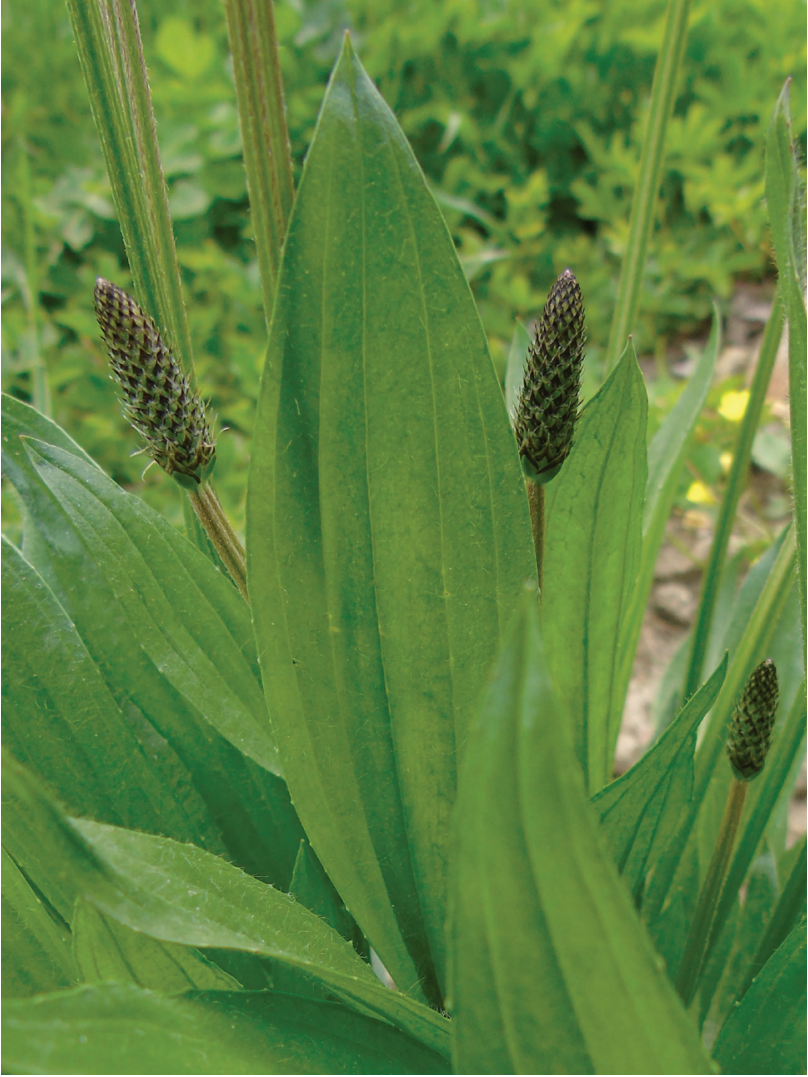

Fig. 11. Plantain (Plantago lanceolata).

Source: own study.

cue techniques, the use of survival psychology skills, signaling assistance, navigation and many others [1].

Ahead of the question about the legitimacy of the discussed topic, you should reach for the basics of learning about tactical medicine and its patterns. As far as the operation of paramedics according to the procedures and algorithms of combat conditions has its justification, if they are medics operating in the structures of uniformed services, should specialized knowledge in this field be provided to "civilian rescuers"? The question is, therefore, whether medical rescuers operating in a civilian environment need detailed knowledge about tactics, firearms, or the ability to eliminate threats used in different services differently, which is a kind of secret. There is no doubt that individual skills borrowed from battlefield medicine are successfully implemented in civil medicine and this is not subject to any discussion. An example could be, among others the use of hemostatic dressings or tactical internships already at the level of first aid recognized and recommended by ERC or ITLS. The point is whether the ability to apply individual procedures in atypical or even extreme conditions in adverse conditions should be considered tactical medicine, or rather, as an element of survival? Continuous training in crisis situations, knowledge of the world around us and the 
opportunities it offers us, and following and overtaking the dangers of the modern world in a conscious way gives us the answer to the question. This text does not contain complicated survival techniques using expensive equipment or taken out of the context of the procedure, but on the real use of knowledge from the everyday surrounding environment.

Survival is based on a peculiar philosophy that should be in constant readiness to accept all sorts of problems related to potential threats. In this connection, it is so important to accumulate knowledge and constantly train survival skills to overcome future life-struggle events. To sum up, it should be stated that survival is in a sense the ability to adapt itself to the external environment and the art of adapting the external environment to your needs. It follows that survival is a skill of self-rescue aimed at protecting oneself and the environment in which a person lives and functions [1]. Are paramedics operating in crisis conditions and their use of survival techniques real? The answer may be the current epidemiological situation in the world.

When analyzing it can be concluded that there is a huge potential that gives us the natural environment in the form of plants that can be successfully used in rescue operations in difficult terrain. It is important that the stereotypes of modern civilization close our perception of exploring the world, limiting ourselves only to the consumption of what is known and recommended. That is why it is so difficult to change the way of thinking and treat even "ordinary weed" as a free way to fight pain and bleeding. The work contains only a fragment of the possibilities that we have on hand each day without complicated procedures for processing plants to use them as an alternative or combination therapy in emergencies under severe stress. The results of the research confirm, however, the willingness of paramedics to participate in classes, workshops and courses on the aspect of survival in emergency medicine. Bearing in mind the training demand on rescue subjects in atypical situations reported by both students and medics, one should consider this problem while looking for top-down solutions and decisions.

\section{CONCLUSIONS}

1. Respondents show interest and a training need in the use of survival techniques used in rescue operations.

2. Almost $95 \%$ of the surveyed students believe that theoretical and practical knowledge of survival would be useful in the profession of a paramedic.

3. Over $90 \%$ of respondents claim that first degree studies in medical rescue do not prepare a paramedic to work in crisis and extreme conditions.

4. Over $70 \%$ of respondents declare that during their professional work / apprenticeship a situation arose in which they felt helplessness due to lack of training.

5. Almost $97 \%$ of the surveyed students believe that universities conducting the field of emergency medicine should introduce obligatory training in the field of behavior in extreme and unusual situations.

6. There is potential that gives us the natural environment in the form of plants that can be successfully used in rescue operations in difficult terrain.

7. A unified, framework curriculum for future medical rescuers should be sought, based on current knowledge in the field of survival techniques used in emergency medical services at the Higher Education level.

8. Consider introducing an obligatory training program and postgraduate training of paramedics in the field of survival techniques in emergency medicine including the necessary skills and knowledge in this field.

\section{REFERENCES}

1. Kucharski Ł. Rola survivalu w ratownictwie medycznym. Policja. 2019;2:46-50.

2. Ustawa z dnia 8 września 2006 r. o państwowym ratownictwie medycznym. Dz. U. 2019; poz. 993.

3. Kucharski Ł. Assessment of the knowledge of police officers of the Police Prevention Department in the field of first aid. Emerg Med Serv. 2020; VII,1: 13 -22.

4. Studzińska - Sroka E, Kozub A, Wagner D et al. Tasznik - pospolity chwast i mało znana roślina lecznicza. Postepy Fitoter. 2012;4:250 - 253.

5. Parus A, Grys A. Babka lancetowata (Plantago lanceolata L.) - właściwości lecznicze. Postępy Fitoter. 2010;3:162-165.

6. https://atlas.roslin.pl/plant/8306, [download:02.04.2020].

7. https://atlas.roslin.pl/plant/6207, [download:02.04.2020].

8. https://atlas.roslin.pl/plant/7610, [download:02.04.2020].

9. Łuczaj Ł. Dzika kuchnia. Warszawa: Nasza Księgarnia, 2013.

10. Łuczaj Ł. Dzikie rośliny jadalne. Przewodnik survivalowy. Krosno: Chemigrafia, 2004. 
ORCID AND CONTRIBUTIONSHIP *

Łukasz Kucharski - 0000-0002-8152-7431 A, l,,c,c,d,e,F

CONFLICT OF INTEREST

Author declares no conflict of interest.
ADDRESS FOR CORRESPONDENCE

Wydział Nauk Medycznych

Wyższa Szkoła Nauk Społecznych z siedzibą w Lublinie ul. Zamojska 47, 20-102 Lublin tel.: 794745294

e-mail: lukaszkucharskiii@wp.pl
RECEIVED

05.04 .2020
ACCEPTED

22.06.2020 


\title{
SEVERE METHEMOGLOBINEMIA WITH UNKNOWN CAUSE - CASE REPORT
}

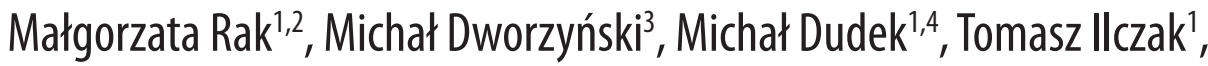 \\ Dariusz Timler ${ }^{3}$, Paweł Krakowiak ${ }^{5}$, Anna Krakowiak²
}
1 FACULTY OF HEALTH SCIENCES, DEPARTMENT OF EMERGENCY MEDICINE, UNIVERSITY OF BIELSKO-BIAŁA, BIELSKO-BIALA, POLAND
2 TOXICOLOGY UNIT, NOFER INSTITUTE OF OCCUPATIONAL MEDICINE, LODZ, POLAND
3 DEPARTMENT OF EMERGENCY MEDICINE AND DISASTER MEDICINE, MEDICAL UNIVERSITY OF LODZ, LODZ, POLAND
4 FACULTY OF HEALTH SCIENCES, MEDICAL UNIVERSITY OF LODZ, LODZ, POLAND
5 MEDICAL UNIVERSITY OF LODZ, LODZ, POLAND

\section{Abstract}

The aim: Methemoglobina is an oxidized form of hemoglobin, which normally doesn 't exceed $1 \%$. It is stated that the amount of methemoglobin over $70 \%$ is fatal. The etiology vary, it might for instance be idiopathic, congenital or caused by toxic compounds.

Material and methods: We analyzed the case of patient who had exceeded the fatal level of methemoglobin in a blood. Case report: Medical Air Rescue Team was dispatched to an 80-year-old patient who suddenly lost consciousness at home. Methemoglobin level was measured using Cobas b221 system and amounted to 75\%. Given the patient's advanced age, congenital causes of methemoglobinemia, such as deficiency of cytochrome-b5 reductase or nicotinamide adenine dinucleotide reductase (NADPH-MHb reductase) were excluded a priori. It seems that the only reason for the observed methemoglobinemia in the case of the examined patient was the acquired methemoglobinemia. The patient was treated with methylene blue with good results, her state improved soon. Despite a detailed interview, it was impossible to establish the etiological factor of methemoglobinemia. None of the household members exhibited clinical symptoms of poisoning with methemoglobinogenic substance. Although the methemoglobin level was potentially deadly, the patients survived.

Conclusion: It should be stressed that it is not always possible to determine the etiological factor of the discussed disorders. Knowledge of the clinical picture of poisoning, as well as of the changes characteristic for poisoning and observable in laboratory, is extremely important, especially when it is not possible to determine the etiological factor of poisoning.

\section{INTRODUCTION}

Methemoglobin is an oxidized form of hemoglobin, which contains $\mathrm{Fe} 3+$ instead of $\mathrm{Fe} 2+$ in the molecule. Methemoglobin is constantly produced in the red blood cells and remains in balance with reduced hemoglobin. When cells are exposed to the excess of the oxidizing compounds, the concentration of methemoglobin derivative increases. The etiology of those disorders might vary; it might for instance have idiopathic or congenital background or be caused by toxic compounds or their methemoglobinforming metabolites (such as food, drugs, toxic substances present in the working environment). Under normal conditions there is a certain amount of methemoglobin present in the body, however, its higher concentration results in clinical symptoms of poisoning which might even lead to death.

There are many compounds which may cause methemoglobinemia, e.g. aniline and its derivatives, dapsone, nitroglycerin (Glyceryl trinitrate, Perlinganit). Nevertheless, it should be stressed that it is not always possible to determine the etiological factor of the discussed disorders; this was the case also for the present case study. It is likely that the current easy access to various products purchased online, such as medicines and food products of unknown origin might be responsible for the development of methemoglobinemia in case of intentional and accidental poisoning. Our case aims to shed light on methemoglobinemia and treating patients with theoretically lethal methemoglobin level.

\section{CASE REPORT}

Medical Air Rescue Team was dispatched to an 80-year-old patient who suddenly lost consciousness at home outside the city area. Prior to the incident, the patient was fully functional. On that day, however, she complained about cough, and communica- 
tion with her started becoming more and more difficult during the day. At the scene of the incident, a doctor of the Emergency Medical Services Team stated that the patient was deeply unconscious and had symptoms of respiratory failure. Vital signs were as follows: non-invasive blood pressure $80 / 50$ $\mathrm{mmHg}$, irregular heart rate $90 / \mathrm{min}$, blood saturation measured with a pulse oximeter on a finger $80 \%$. Her state of consciousness was assessed as 4 points on the Glasgow Coma Scale and neurological examination revealed abnormal extension of her left limbs in response to the pain stimulus. Moreover, the doctor noted a significant central cyanosis. The patient was intubated using RSI (rapid sequence induction) method, sedated and connected to a ventilator, $\mathrm{FiO}_{2}$ $100 \%$, final expiratory carbon dioxide concentration was normal. The medical history concerning chronic diseases was taken and it revealed that the patient suffered from a number of cardiovascular diseases including arterial hypertension and persistent atrial fibrillation. As a result, the patient was regularly taking dabigatran as means of anticoagulant prophylaxis. Taking into account the whole clinical situation, the emergency physician suspected the patient might be suffering from a hemorrhagic stroke and qualified her for an urgent transport to a multispecialty clinic,
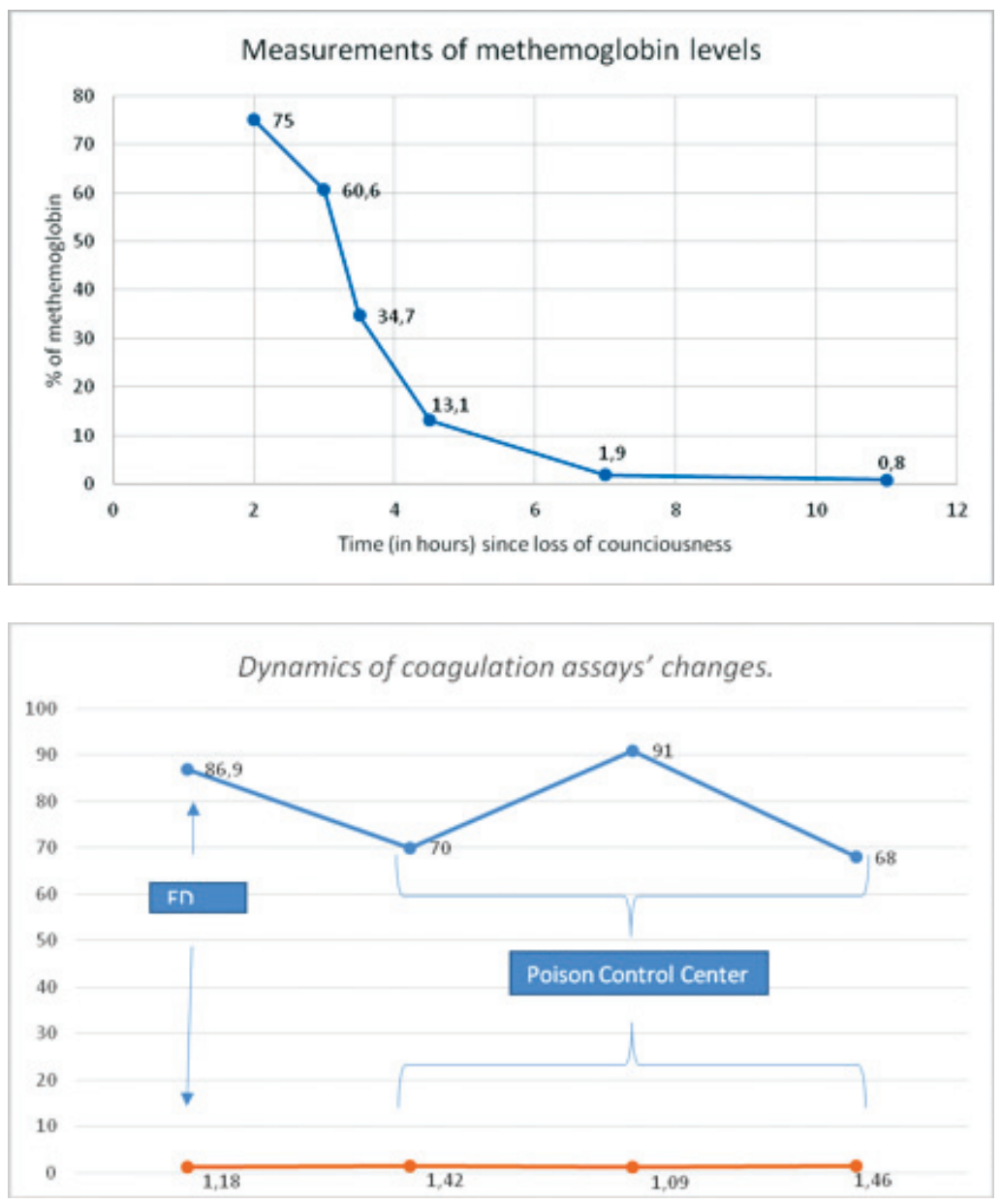

which had neurosurgical and intensive care facilities at its disposal. Due to the considerable distance, an emergency helicopter of the Medical Air Rescue Team was deployed.

At the scene, the Medical Air Rescue physician stated that the patient was deeply unconscious, sedated and with breathing replaced by mechanical ventilation. Despite $100 \%$ oxygen ventilation, cyanosis persisted and the saturation measured with a pulse oximeter on a finger remained between 80 and $85 \%$. Moreover, slight hypotension and tachycardia were diagnosed. Patient's general condition did not change during the transport.

The patient was admitted to the Emergency Department of the multispeciality hospital about 1 hour 15 minutes after the loss of consciousness. Her general condition and vital signs did not differ from those measured at the site and during the initial assessment significant cyanosis of the whole skin was noted. The color of the blood samples taken for laboratory tests was chocolate-brown. The clinical picture indicated methemoglobinemia. Methemoglobin level was measured using Cobas b221 system and amounted to $75 \%$, arterial blood gas parameters were as follows: $\mathrm{pH}$ 7.306, $\mathrm{pO}_{2} 255.3 \mathrm{mmHg}, \mathrm{pCO}_{2} 35.2 \mathrm{mmHg}, \mathrm{BE}-8.2$ $\mathrm{mmol} / 1$, satO ${ }_{2}$ calculated: $99.8 \%, \mathrm{HCO}_{3} 17.2 \mathrm{mmol} / \mathrm{l}$.
Fig. 1. Subsequent measurements of methemoglobin levels. The arrows indicate antidote administration - methylene blue.
Fig. 2. Prothrombin index (blue values) and INR (orange values) in the Emergency Department (ca. 2 hours since consciousness loss) and the Regional Toxicology Unit $\left(2^{\text {nd }}, 4^{\text {th }}\right.$ and $8^{\text {th }}$ day since poisoning). 
Despite obvious methemoglobinemia, the patient underwent the standard procedure for suspected stroke. Head CT scan and chest X-ray did not reveal any pathology. Laboratory results remained normal with slightly elevated levels of high-sensitivity troponin $(30 \mathrm{ng} / \mathrm{l})$ and hyperglycemia $(250 \mathrm{mg} / \mathrm{dl})$. The patient's condition was consulted on the phone with the Regional Poison Control Center and as a result methylene blue was recommended for treatment. However, due to the lack of this antidote, she was referred to the Center after initial diagnosis.

On admission to the Poison Control Centre, the patient was in a critical condition, with respiratory failure and on ventilator, $\mathrm{FiO}_{2} 100 \%$. Heart rate was irregular with ventricular rate 140/min, electrocardiography showed atrial fibrillation. The diagnostic tests revealed the methemoglobin level of $60.6 \%$, so the antidote 1 ampoule of methylene blue - was administered, followed by another half an ampoule, which reduced methemoglobin concentration to 13\% (Fig. 1). Subsequent tests showed decline in methemoglobin concentration to $0.6 \%$. The patient's condition improved, she was extubated and full verbal and logical contact was established. Physical examination concluded that the patient was cardiovascularly and respiratorily stable.

During the hospitalization, the patient developed clinical symptoms of pneumonia confirmed by X-ray imaging (lung X-ray) and laboratory tests (CRP), in consequence empirical antibiotic therapy was administered. During the hospitalization, a temporary slight decrease in red blood cell parameters and prothrombin index was observed (Fig. 2).
The level of red blood cell parameters slightly differed in subsequent tests: on the day of poisoning hemoglobin level was $15.0 \mathrm{~g} / \mathrm{dl}$, hematocrite $47.1 \%$, erythrocytes $5.37 \times 106 / \mu 1 ; 2^{\text {nd }} d a y$ : hemoglobin 13.0 $\mathrm{g} / \mathrm{dl}$, hematocrite $39.8 \%$, erythrocytes $4.62 \times 106 / \mu 1$, $8^{\text {th }}$ day: hemoglobin $14.4 \mathrm{~g} / \mathrm{dl}$, hematocrite $44.7 \%$, erythrocytes $5.09 \times 106 / \mu 1$.

The patient also received psychological consultation. Symptoms of organic emotional and behavioral disorders were diagnosed.

Despite a detailed interview, it was impossible to establish the etiological factor of methemoglobinemia. None of the household members exhibited clinical symptoms of poisoning with methemoglobinogenic substance.

On day 9, the patient was transferred from the Poison Control Center to the Department of Internal Medicine for further treatment, with the indication, that an immediate psychiatric consultation is required after end of treatment due to likely intentional poisoning.

\section{DISCUSSION}

Sudden loss of consciousness was the only symptom that was observed by the family and which caused them to call the Emergency Medical Services. Due to possible suicidal intentions, the patient probably did not report any ailments which would allow family members to take rescue measures earlier.

The clinical signs of poisoning depend on methemoglobin levels with values above $70 \%$ considered lethal (Table 1) [1].

Table 1. Symptoms exhibited by patients depending on the severity of methemoglobinemia.

$\begin{array}{cc}\text { Methemoglobin [\%] } & \text { Symptoms } \\ <10 & - \\ 10-20 & \text { Skin cyanosis } \\ 20-30 & \text { Anxiety, weakness, headaches, tachycardia } \\ 30-50 & \text { Fatigue, disorientation, dizziness } \\ 50-70 & \text { Seizures, loss of consciousness } \\ >70 & \text { Death }\end{array}$

Table 2. Guidance saturation values of $\mathrm{pO}_{2}$ and $\mathrm{pCO}_{2}$ in different clinical conditions depending on the measurement.

\begin{tabular}{|c|c|c|c|c|c|}
\hline Parameters & $\mathrm{pO}_{2}$ in arterial blood & $\mathrm{pCO}_{2}$ & Arterial blood gas & Pulse oximeter & Co-oximeter \\
\hline Normal & 95 & 40 & 95 & 95 & 95 \\
\hline Anemia & 95 & 40 & 95 & 95 & 95 \\
\hline $\begin{array}{l}\text { Methemoglobinemia } \\
(30 \%)\end{array}$ & 95 & 35 & 95 & 85 & 70 \\
\hline $\begin{array}{c}\text { Carboxyhemoglobin } \\
(30 \%)\end{array}$ & 95 & 35 & 95 & 95 & 70 \\
\hline COPD & 60 & 50 & 90 & 90 & 90 \\
\hline $\begin{array}{l}\text { Massive pulmonary } \\
\text { embolism }\end{array}$ & 75 & 40 & 75 & 80 & 80 \\
\hline
\end{tabular}


Table 3. Various compounds causing methemoglobinemia.

\begin{tabular}{ll} 
Substance type & \multicolumn{1}{c}{ Compounds causing methemoglobinemia } \\
Vasodilators & Nitroglycerin, sodium nitroprusside, nitrous oxide \\
Analgesics & Buprenorphine, celecoxibe, ibuprofen, phenazopirydine, fenacetine \\
Antimicrobial & Dapsone, nitrofurans, sulphonamides, chinolones, silver salts \\
Local anesthetics & Prilocaine, benzocaine, lidocaine, tetracaine \\
Industrial & Aniline, naphtalene, nitrates, nitrites, trinitrotoluene, chlorobenzene \\
Herbicides, pesticides & Paraquat, dinitrotoluene \\
Others & Vehicle exhaust gases, compunds created during wood and plastic incineration, acidosis in children
\end{tabular}

Linz et al. described the symptoms occurring at lower levels of methemoglobin in rubber industry workers exposed to nitrobenzene at their workplace [2]. At the methemoglobin level of 3\% symptoms included headaches, at 9\% - general feeling of being unwell, skin cyanosis, at 25\% - impaired thinking ability, dizziness, at $27 \%$ - additionally nausea, ataxia, burning sensation and at $41.2 \%$ loss of consciousness and seizures. In the discussed case, abnormal extension of left limbs was observed, which can be considered equivalent to seizures.

Methemoglobinemia occurs when the concentration of methemoglobin in blood exceeds $1 \%$. As examined case shows, correct diagnosis of methemoglobinemia was possible thanks to the difference between the saturation measured by the pulse oximeter and the saturation calculated from arterial blood gas with high values of $\mathrm{pO}_{2}$ in arterial blood sample. The patient's pulse oximeter readings oscillated around $85 \%$ and did not change despite administering $100 \%$ oxygen for breathing. This is typical in methemoglobinemia due to the specificity of pulse oximetry. The pulse oximeter examines the blood cells' absorption of light (wavelengths of $660 \mathrm{~nm}$ and $940 \mathrm{~nm}$ ) and calculates saturation based on this data. It is a fast and quite precise method of testing oxygen saturation of patients' blood, however, there is also risk of obtaining false readings. Readings can be imprecise in case of low blood pressure, insufficient perfusion, hypothermia, some valve defects or presence of other forms of hemoglobin, including methemoglobin, carboxyhemoglobin and sulfhemoglobin. Measurement errors in such cases result from the fact that other forms of hemoglobin absorb light waves used by a pulse oximeter, which in turn leads to measurement overestimation and does not reflect the real level of oxygenated hemoglobin. [3]. In the case of methemoglobinemia, the altered hemoglobin absorbs both wavelengths, so the pulse oximeter gives the result of about $84-86 \%$, which was the case here. What points towards methemoglobinemia instead of lung disease are high levels of $\mathrm{pO}_{2}$ in ar- terial blood, which suggest correct oxygenation of blood, and therefore absence of clinically significant lung disease. The difference between measured and calculated saturation is called saturation gap. The $\mathrm{pCO}_{2}$ concentration is equally important in blood gas test; in examined case it did not indicate any pulmonary disorders. It also seems beneficial to use a co-oximeter, which measures light absorption using wavelengths corresponding to four forms of hemoglobin: oxidized, non-oxidized, methemoglobin and carboxyhemoglobin (Table 2).

It is worth mentioning that in methemoglobinemia blood changes its color to chocolate-brown, which is a very characteristic symptom pointing to this condition. Therefore, the cooperation and clear communication between medical and nursing staff in the diagnostic and therapeutic process plays an important role.

In poisoning with some methemoglobinogenic substances, globin (so-called Heinz-Ehrlich bodies) precipitates in red blood cells. It is believed that Heinz bodies are composed of pathologically altered proteins. Their appearance indicates significant damage to the red blood cells. Luckily none of the abovementioned abnormalities were reported in the case of the hospitalized patient.

In the examined case, the etiological factor of methemoglobinemia could not be established. Many factors contributing to development of methemoglobinemia have been described. Some of the best known include: aniline, dapsone, lidocaine, prilocaine, metoclopramide, naphthalene, nitrites, nitric oxide, nitroglycerin, sodium nitroprusside, paraquat, phenacetin and sulfonamides. In other cases, the cause may not be obvious; for instance, drinking water from a well contaminated with nitrates, gels containing topical anaesthetics used for teething infants, vegetables containing nitrates such as broccoli, cauliflower, spinach, carrots, but also vegetables used in Asian cuisine (e.g. choy sum) (Table 3). Other causes might include acidosis in infants under 6 months of age or congenital disorders such as deficiency of glucose-6-phosphate dehydrogenase 
The above-mentioned compounds can be divided into oxidizing directly or indirectly, e.g. causing methemoglobinemia through the reactive forms of oxygen or water they produce. Some substances act in this way only through their metabolites. Since every individual has a different metabolism, the course of poisoning may vary among those exposed to such substances, which was observed in children after ingestion of topical anaesthetics [4].

The concentration of methemoglobin in the described case exceeded the values considered as lethal. Patient's hemoglobin level was initially $15.0 \mathrm{~g} /$ $\mathrm{dl}$, which in the case of methemoglobinemia of $75 \%$ gives $3.75 \mathrm{~g} / \mathrm{d}$ l of haemoglobin capable of effectively transporting oxygen to the tissues. It is estimated that the reduction of methemoglobin to haemoglobin as a result of natural metabolic pathways is $15 \% / \mathrm{h}$ of the methemoglobin value, e.g. in this case $15 \% \times 75=$ $11.25 \% /$ first hour. Between the first and the second measurement of methemoglobin level about 1.5 hour passed, which corresponds to the difference between the first two measurements. The measurements were obtained with the same method using Cobas b221.

In the case described neither methemoglobinemia recurrence nor hemolysis was observed. The treatment consisted in using an antidote, methylene blue, which quickly lowered the level of methemoglobin. The first dose of $100 \mathrm{mg}(1.6 \mathrm{mg} / \mathrm{kg}$ b.w.) lowered the level of methemoglobin to $34.7 \%$ within 20 minutes; therefore, it was decided to administer additional $50 \mathrm{mg}$ of the above-mentioned drug ( $0.8 \mathrm{mg}$ per kg body weight). The methemoglobin level measured once again after an hour was $13.1 \%$. The patient did not require blood transfusion or hyperbaric oxygen therapy.

Given the patient's advanced age ( 80 years old), congenital causes of methemoglobinemia, such as deficiency of cytochrome-b5 reductase or nicotinamide adenine dinucleotide reductase (NADPH-MHb reductase), also known as flavin adenine dinucleotide reductase, were excluded a priori. It seems that the only reason for the observed methemoglobinemia in the case of the examined patient was the acquired methemoglobinemia.

Taking into account the lack of clinical symptoms of poisoning in other members of the family and the fact that all household members obtained water from the same source, e.g. tap water, it was possible to exclude contamination of water with inorganic nitrates. Such contamination is a frequent cause of methemoglobinemia, especially in children $[5,6]$. The patient was not exposed to any other methemoglobinogenic substances, e.g. those listed in Table 3. Source literature describes cases of methemoglobinemia occurring after eating vegetables containing nitrites, e.g. choy sum [7]. Nevertheless, according to the history taken, the patient consumed the same meals as the rest of household members. It is also possible to illegally order certain drugs online without prescription, for instance phenazopyridine (Nefrecil, Pyridium), but it seems unlikely that the patient would acquire a methemoglobinogenic substances this way. Most probably, she used one of household chemicals, such as wood preservative, as its disappearance from the basement or garage would not be easily noticed by her family.

\section{CONCLUSIONS}

Acquired methemoglobinemia is a serious condition that may pose a threat to patient's health and life.

In many cases it is possible to determine the etiological factor of poisoning [8], which significantly facilitates the diagnostic process and speeds up the application of appropriate treatment.

Knowledge of the clinical picture of poisoning, as well as of the changes characteristic for poisoning and observable in laboratory, is extremely important, especially when it is not possible to determine the etiological factor of poisoning [9].

\section{REFERENCES}

1. Benz EJ. Hemoglobinopathies (methemoglobinemias). In: Kasper DL, et al (eds). Harrison's Principles of Internal Medicine. 16th edn. New York: McGrawHill; 2005:597-598.

2. Linz AJ, Greenham RK, Fallon LF Jr. Methemoglobinemia: an industrial outbreak among rubber molding workershttps://www.editorialsystem.com/ems/article/198767/references/\#. J Occup Environ Med. 2006 May;48(5):523-8.

3. Barker SJ, Tremper KK, Hyatt J. Effects of methemoglobinemia on pulse oximetry and mixed venous oximetry. Anesthesiology. 1989 Jan;70(1):112-7.

4. Wright RO, Lewander WJ, Woolf AD. Methemoglobinemia: etiology, pharmacology and clinical managment. Ann Emerg Med. 1999; 34: 646-656.

5. Niećko J, Sobótka M, Kukułka-Niećko U, Niećko M. [The level of nitrates in drinking water of selected water wells situated in the parish of Szydlowiec]. Przegl Lek. 2001;58(Suppl 7):25-9.

6. Knobeloch L, Salna B, Hogan A, Postle J, Anderson H. Blue babies and nitrate-contaminated well water. Environ Health Perspect. 2000 Jul;108(7):675-8. 
7. Chan HTC, Hui AWH, Graham C, Walline J. My mother is looking blue. World J Emerg Med. 2019;10(4):251-252.

8. Rośniak-Bąk K, Bąk M, Winnicka R, Krakowiak A. Accidental severe poisoning with methemoglobinogenic substance: A case report. Med Pracy 2017;68(6):795-801.

9. Paczek A, Wawrzyńska L, Mendek-Czajkowska E, Kober J, Torbicki A. Acquired methemoglobinemia case report. Pneumonol Alergol Pol 2010;78(2):153-158.

ORCID AND CONTRIBUTIONSHIP*

Małgorzata Rak - 0000-0003-0911-5309 D

Michał Dworzyński - 0000-0001-8435-644X

Michał Dudek - 0000-0003-3042-8879 '

Tomasz Ilczak - 0000-0003-2478-9045 A

Dariusz Timler - 0000-0002-5415-5660 $\mathbf{E}$

Paweł Krakowiak - 0000-0002-6660-7150 ${ }^{\text {B }}$

Anna Krakowiak - 0000-0002-2832-8302 ${ }^{\mathbf{F}}$

\section{CONFLICT OF INTEREST}

Authors declare no conflict of interest.

\section{ADDRESS FOR CORRESPONDENCE}

Małgorzata Rak

Katedra Ratownictwa Medycznego

Wydział Nauk o Zdrowiu

Akademia Techniczno-Humanistyczna w Bielsku-Białej

Bielsko-Biała, Willowa 2

43-309, Bielsko-Biała, Poland

tel: +48888830851

e-mail: malgorzatarak999@gmail.com 


\title{
THE CONCEPT OF DAMAGE CONTROL RESUSCITATION (DCR) IN THE PREHOSPITAL AS WELL AS IN-HOSPITAL SETTING - A CASE REPORT
}

\author{
Wojciech Stefaniak, Łukasz Rozbicki
}

EMERGENCY DEPARTMENT, THE JOHN PAUL II POVIAT HOSPITAL, BARTOSZYCE, POLAND

\section{Abstract}

The aim of the study was to present the principles of the "damage control resuscitation" strategy based on a case report of a patient with multi-organ trauma at the pre-hospital and in-hospital settings. In addition to the fastest possible implementation of care at the pre-hospital level, a very important factor influencing the effectiveness of actions is the decision of the head of the emergency medical team to choose the place of transport of the patient (the nearest poviat Emergency Department or a remote Trauma (enter). This should be conditioned not only by anatomical injuries and physiological parameters of the victim, but also other elements, depending on local possibilities.

\section{Key words}

\author{
Damage Control Resuscitation, \\ multi-organ trauma, \\ Trauma Center, \\ Emergency Department, \\ triad of death
}

\section{INTRODUCTION}

The terminology of the proceedings comes from the US Navy, where the term ,damage control" means the ability of the ship to compensate the damage and to perform the mission [2-4]. The current assumptions of the damage control resuscitation (DCR) in pre-hospital and in-hospital care are based on the experience of military surgeons who developed the concept of damage control surgery, i.e. surgical interventions limited to the necessary minimum in order to quickly stop massive bleeding and hemodynamic stabilization of the patient and further targeted surgical procedures after achieving homeostasis [6]. The DCR proceedings defines the principles of early and systematic implementation of care for a patient with multi-organ trauma, with particular emphasis on the rapid diagnosis and treatment of hemorrhagic shock. The aim of the therapy is to obtain and maintain the patency and ventilation of the airways, initiate and continue fluid resuscitation, preferably with the use of blood products, and to counteract acidosis and hypothermia [2-5]. Implementation should begin much earlier than surgical intervention, usually during land or air transport of a critically ill patient and/or at the emergency department (ED) [2]. The case report presents the DCR management in a patient with multi-organ trauma during pre-hospital and in-hospital care. The patient was treated by the emergency medical service (EMS) team and the ED of the John Paul II Poviat Hospital in Bartoszyce.

\section{CASE REPORT}

On December 16, 2019, EMS team P N01 36 stationed about $18 \mathrm{~km}$ from the scene of the incident received an emergency dispatch order to a cyclist hit on the national road No. 51. Travel time was about 10 minutes. A second P N01 34 team, passing by accidentally, appeared on the spot, returning from the completed intervention, moreover, a police patrol was present, and fire brigade units were on the way. The injured was a man aged about 60 , lying in a ditch on the right side, with all vital functions preserved. Witnesses confirmed the version of the hit by the bus. A damaged bicycle frame and dents in the vehicle's body were also found. In the initial assessment, there was no obvious external bleeding, the patient was conscious, assessed A in the AVPU scale, breathing approx. 24/min and with the present carotid pulse approx. 100/min. In the rapid trauma examination, no symptoms of imminent life-threatening conditions were recognized; however, the assessment was uncertain due to thick clothing and forced position of the body on the side. Due to the low ambient temperature of about $4^{\circ} \mathrm{C}$, moderate wind and rainfall, the EMS leader decided to quickly evacuate the victim to an ambulance using an orthopedic board. Medical history according to SAMPLE was performed (the injured person complained of pain in the left upper limb and left half of the chest, he denied chronic allergies and diseases, took constant medications, ate breakfast, with amnesia of the event). In a further 
trauma examination, the chest instability was located on the left side, with a slight asymmetry of the respiratory murmur on the left side, with no evident features of tension pneumothorax or flaccid chest, but with a board hard abdomen with significant muscular guarding, and with left upper limb instability. Baseline vital signs were as follows: heart rate (HR) $110 / \mathrm{min}$, respiration rate (RR) approx. 24/min, $\mathrm{SpO}_{2} 87 \%$, blood pressure (BP) 79/49 $\mathrm{mmHg}$, and capillary refill time (CRT) $4-5 \mathrm{sec}$. Also, there was a tendency to sleepiness with voice response (AVPU-V). Oxygen supplementation was implemented via the mask with a reservoir of $10 \mathrm{~L} / \mathrm{min}$, the $18 \mathrm{G}$ vein access into the external jugular vein was secured, and low-volume fluid resuscitation with peripheral perfusion control was initiated. Analgesic treatment was initiated $(0.1 \mu \mathrm{g} i . v$. fentanyl) and the patient was thermally secured.

Due to the developing symptoms of shock, the estimated travel time of approx. 50 minutes to the Trauma Center in Olsztyn, the EMS leader decided to transport the patient to the ED in Bartoszyce, transmitting the patient's clinical condition by radio. The information was confirmed in TRIAGE, the work in the ED was reorganized and the resuscitation and treatment room was prepared in accordance with the checklist. The trauma team consisted of two doctors (emergency medicine specialist - head and a doctor during specialization training in the field of emergency medicine, a nurse and two paramedics). The transfer took place directly in the resuscitation and treatment room at 12:00. In the first assessment, the patient's condition was very serious, with no visible external bleeding. In the $\mathrm{ABC}$ assessment, the injured person was sleepy, responding to the voice $-\mathrm{V} / \mathrm{AVPU}$, with no signs of a threat to the patency of the upper respiratory tract, B - breathing 30/min; C - heart rate 100/min. In the trauma examination, the most significant deviations were abnormal chest movement on the left side with the use of accessory respiratory muscles and the current respiratory effort, with the simultaneous normal alveolar murmur, deformation of the left upper limb, soreness and tenderness on the left side - injuries appropriate to the mechanism of the injury. In the first assessment of vital parameters, the following values were obtained: 12:08 (Table 1).

In the e-FAST study, pneumothorax was excluded, there was a small amount of free fluid in the hepatorenal recess and an image of the spleen, which indicated its contusion or rupture. The surgical ward and the operating theater were informed by phone about the event, and the planned surgery was postponed. Arterial blood was collected from the femoral artery under ultrasound guide, and secured for analytical and serological examination, and for the analysis of critical parameters. The following values were obtained (Table 2).

Morphine sulphate $10 \mathrm{mg}$ i.v., tranexamic acid $1 \mathrm{~g}$ i.v. and a multi-electrolyte fluid heated to $40^{\circ} \mathrm{C}$ were used in the initial pharmacological treatment. Antihypothermia treatment with an external air heater was also applied. At 12:15, control life measurements were assessed (Table 3).

The patient was intubated with a tube $8 \mathrm{~mm}$ in RSI mode using ketamine and succinylcholine chloride and ventilated in CMV mode. Due to the recurrence of hypotension, a norepinephrine infusion was ordered. The bedside chest X-ray revealed multiple fractures of five ribs on the left side, with areas of lung contusion without signs of pneumothorax and hematoma in the pleural cavity. A CT examination in the polytrauma protocol was ordered. In laboratory tests, features of blood loss were observed: a decrease in $\mathrm{Hgb} 10.4 \mathrm{~g} / \mathrm{dL}(12: 15 \mathrm{pm}) \rightarrow 9.5 \mathrm{~g} / \mathrm{dL}$ (12:45). In

Table 1. The first assessment of vital parameters.

\begin{tabular}{|c|c|c|c|c|}
\hline 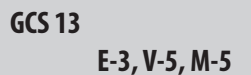 & $\begin{array}{c}\text { HR } \\
106 / \mathrm{min}\end{array}$ & $\begin{array}{c}\text { BP } \\
64 / 36 \mathrm{mmHg}\end{array}$ & $\begin{array}{c}\text { Respiration rate } \\
18 / \text { min }\end{array}$ & $\begin{array}{l}\mathrm{SpO}_{2} 99 \% \\
\text { on oxygen }\end{array}$ \\
\hline
\end{tabular}

Temp. $36.6^{\circ} \mathrm{C}$

Glycemia 16 mg\%

Table 2. The second assessment of vital parameters.

\begin{tabular}{lllll}
$\mathrm{pH}$ & $\mathbf{p C O _ { 2 }}$ & $\mathbf{p O}_{2}$ & $\mathrm{BE}$ & $\mathrm{HCO}_{3-}$ \\
$\mathbf{7 . 4 2 5}$ & $\mathbf{2 8 . 8} \mathrm{mmHg}$ & $\mathbf{7 1} \mathrm{mmHg}$ & $-5 \mathrm{mmol} / \mathrm{L}$ & $\mathbf{1 8 . 9} \mathbf{m m o l} / \mathrm{L}$ \\
\hline $\mathrm{SpO}_{2}$ & $\mathrm{Na}$ & $\mathrm{K}$ & $\mathrm{Hct}$ & $\mathrm{Hgb}$ \\
$95 \%$ & $134 \mathrm{mmol} / \mathrm{L}$ & $4.5 \mathrm{mmol} / \mathrm{L}$ & $31 \%$ & $10.5 \mathrm{~g} / \mathrm{dL}$
\end{tabular}

Table 3. The third assessment of vital parameters.

\begin{tabular}{lllll} 
GCS 12 & HR & BP & Respiration rate 20/min & $\mathrm{SpO}_{2}$ \\
E-3, V-4, M-5 & $90 / \mathrm{min}$ & $80 / 52 \mathrm{mmHg}$ & & $\mathbf{9 8 \% \text { on oxygen }}$ \\
\hline
\end{tabular}

Temp. $36.6^{\circ} \mathrm{C}$ 
the follow-up e-FAST examination, a significant increase in the volume of free fluid in the peritoneal cavity, a blunt abdominal trauma with intra-abdominal bleeding was diagnosed. In the meantime, there was a gradual deterioration in general condition after initial improvement. In consultation with a surgeon, the patient was qualified for emergent laparotomy without CT examination. From the ED, two units of concentrated red blood cells and two units of freshfrozen plasma were ordered. The patient, after 50 minutes of his stay in the ED, was transferred directly to the operating theatre. Intraoperative diagnosis was spleen rupture, diaphragm wound, ascending colon sera rupture, and mesenteric contusion. The patient in a severe, but stable condition, was transferred after surgery for further treatment in the intensive care unit (ICU).

\section{DISCUSSION}

Multi-organ injuries are still one of the leading causes of death in the world [5], and for the EMS system, both in pre-hospital and in-hospital care, they are one of the most demanding conditions. They require the efficient and, most importantly, systematized approach to the patient [6], with particular emphasis on cooperation and excellent communication, as well as trust at all stages of the procedure between various departments of the hospital facilities. The presented description of the proceedings fully presents the assumptions of the DCR procedure. The implemented strategy ensured efficient and, most importantly, effective prevention of the so-called triad of death, i.e. hypothermia, coagulopathy and acidosis with the final protection of active bleeding and stabilization of the patient's vital parameters. Beginning with quick evacuation from the scene of the incident with minimization of activities performed (quick trauma examination, fluid resuscitation with small volumes under pressure control $[1,3]$, quick information to the ED about the patient's condition) through actions in the ED (reorganization of the department's work, quick identification of the immediate state threats to life, minimizing the diagnostic and therapeutic process based solely on the ED equipment, securing blood products) to quick surgical intervention (trust and communication between the ED and the operating theater, reorganization of the operating theater) and commencement of the further treatment process in the ICU.
This case shows that while the patient in the prehospital assessment met the criteria for treatment at the Trauma Center in Olsztyn, the final decision should also take into account the estimated time of arrival with the use of EMS or Helicopter-EMS, which may contribute to the deterioration of health, including post-traumatic cardiac arrest. Experience shows that other variables influence on the choice, such as: dynamics of changes in the patient's clinical condition, the road infrastructure condition, knowledge of local procedures, the level of training and experience of members of the EMS team / ED, knowledge of the current staffing of EMS team / ED, difficulties in the transfer of patients from the ED to centers with a higher level of reference. In the case presented above, the decision to transport to the nearest ED turned out to be right in retrospect, nevertheless, in the opinion of the authors of the study, making the decision about the destination is one of the most difficult at the level of pre-hospital care. It is also right to take steps to change the regulations governing the scope of paramedics' competences, extending them to the possibility of supplying tranexamic acid, as indicated by medical practice based on current and reliable publications $[2,4,5]$.

\section{CONCLUSIONS}

Although the infrastructural assumptions for the functioning of the ED seem to be sufficient to ensure adequate care for patients in emergency health conditions, such as multi-organ trauma, a much more difficult issue to implement is to ensure an appropriate level of training of medical personnel, work organization, proper management, building trust between units of the EMS teams / ED, and other hospital departments. The experience of the Poviat Hospital in Bartoszyce as the dispatching unit of EMS team and ED clearly confirms the need to treat not only these two elements of the EMS system as one "organism"; but also the entire hospital facilities (hospital departments, operating theater, analytical laboratory, diagnostic imaging department, blood bank) to ensure quick and effective help to patients in emergencies. Moreover, this indicates not only the need for poviat $\mathrm{ED}$, but also the need for support at every level, especially in places far away from trauma centers or multi-profile hospitals, so as to maintain the rules of the "golden hour".

\section{REFERENCES}

1. Nur AK, Mohd AMM, Izzat I, et al. Damage control resuscitation: A case of thoracoabdominal impalement. Med J Malaysia, 2016;71(2):77-78.

2. Sklar R, Han K. Stanowisko ITLS w sprawie postępowania typu Damage Control (DCR) i postępowania w krwotoku/wstrząsie w warunkach przedszpitalnych. Med Prakt Rat (online) 26.09.2019 [download: 
06.03.2020] https://www.mp.pl/ratownictwo/urazy/217284,stanowisko-itls-w-sprawie-postepowaniatypu-damage-control.

3. Ball CG. Damage control resuscitation: history, theory and technique. Canad J Surg. 2014; 57(1): 55-60. doi: $10.1503 /$ cjs.020312.

4. Cap AP, Pidcoke HF, Spinella P, et al. Damage Control Resuscitation. Milit Med. 2018; Suppl 2:36-43. doi.10.1093/milmed/usy112.

5. Mizobata Y. Damage control resuscitation: a practical approach for severely hemorrhagic patients and its effects on trauma surgery. J Intes Care, 2017;5(4). doi.org/10.1186/s40560-016-0197-5.

6. Dawes R, Rhys T, Wyldbor M. Damage Control Resuscytation. In: Buckenmeier Ch, Mahoney PF (eds). Combat anesthesia: The first 24 hours. Office of The Surgeon General Borden Institute: Fort Sam Houston, Texas; 2015. pp. 89-95.

\section{ORCID AND CONTRIBUTIONSHIP *}

Wojciech Stefaniak - 0000-0002-8284-1748 A,B, D,E,F

Łukasz Rozbicki - 0000-0001-9936-8566 A,,B,D,E,F

\section{CONFLICT OF INTEREST}

Authors declare no conflict of interest.

\section{ADDRESS FOR CORRESPONDENCE}

Wojciech Stefaniak

Szpitalny Oddział Ratunkowy i Dział Ratownictwa Medycznego

Szpital Powiatowy im. Jana Pawła II w Bartoszycach ul. Kardynała Stefana Wyszyńskiego 11

11-200 Bartoszyce, Poland

e-mail: w.stefaniak@szpital-bartoszyce.pl
RECEIVED

10.02 .2020
ACCEPTED

07.04.2020 